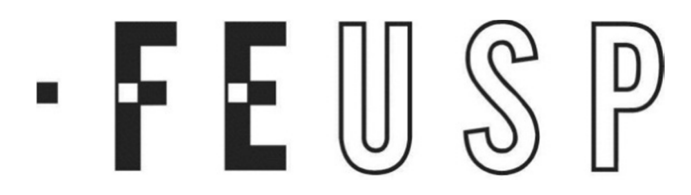

Faculdade de Educação da Universidade de São Paulo

FÁBIO MARQUES DE SOUZA

O cinema como mediador na (re)construção de crenças de professores de espanhol-língua estrangeira em formação inicial

[versão revisada]

São Paulo - SP

2014 

FÁBIO MARQUES DE SOUZA

\section{O cinema como mediador na (re)construção de crenças de professores de espanhol-língua estrangeira em formação inicial}

Tese apresentada ao Programa de Pós-Graduação em Educação da Faculdade de Educação da Universidade de São Paulo como exigência parcial para obtenção do título de doutor em educação.

Área de Concentração: Cultura, organização e educação.

Orientador: Prof. Dr. Afrânio Mendes Catani.

São Paulo - SP

2014 
Autorizo a reprodução e divulgação total ou parcial deste trabalho, por qualquer meio convencional ou eletrônico, para fins de estudo e pesquisa, desde que citada a fonte.

Catalogação da publicação

Serviço de Biblioteca e Documentação

Faculdade de Educação da Universidade de São Paulo

\section{Souza, Fábio Marques de.}

"O cinema como mediador na (re)construção de crenças de professores de espanhol-língua estrangeira em formação inicial"

Tese (Doutorado - Programa de Pós-graduação em Educação. Área de Concentração: Cultura, organização e educação). Faculdade de Educação da Universidade de São Paulo, 2014.

1. Espanhol - língua estrangeira (E-LE); 2. Formação de professores; 3. Crenças; 4. Cinema; 5. Integração latino-americana. 
SOUZA, Fábio Marques de. O cinema como mediador na (re)construção de crenças de professores de espanhol-língua estrangeira em formação inicial. Tese apresentada à Faculdade de Educação da Universidade de São Paulo para a obtenção do título de doutor em Educação.

Aprovada em: 13/06/2014.

\section{Banca Examinadora}

Prof. Dr Afrânio Mendes Catani Instituição: FE-USP

Julgamento: Assinatura:

Prof. Dr. Amaury Cesar Moraes Instituição: FE-USP

Julgamento: Assinatura:

Profa. Dra. Cristina Bongestab Instituição: CCHE-UEPB

Julgamento: Assinatura:

Profa. Dra. Maria de Lourdes Otero Brabo Cruz Instituição: FCL-UNESP Julgamento: Assinatura:

Profa. Dra. Maria Helena Vieira Abrahão Instituição: IBILCE-UNESP

Julgamento: Assinatura:

Suplentes:

Dra. Ana Cristina Biondo Salomão (UNESP/Araraquara)

Dra. Elda Firmo Braga (UERJ)

Dra. Isabel Gretel María Eres Fernández (FE-USP)

Dra. Mona Mohamad Hawi (FFLCH/USP)

Dra. Viviane Conceição Antunes (UFRRJ) 

À Angela Patrícia (Paty), Nathália, Penélope, Lisa, Panqueca, Brigadeiro, Suspiro e Caramelo, com quem tenho aprendido a mais difícil e prazerosa tese: viver o amor no dia a dia... 



\section{AGRADECIMENTOS}

Gracias a la vida que me ha dado tanto (...) Me ha dado el sonido y el abecedario, con él las palabras que pienso y declaro (...) y el canto de ustedes que es el mismo canto, y el canto de todos, que es mi propio canto (Trecho da canção Gracias a la vida, de Violeta Parra).

São muitas as fontes que contribuíram, de alguma forma, com a minha formação como pessoa e pesquisador. Assim sendo, seria inviável, por limitações de espaço e de memória, relacionar e agradecer a todos aqui. No que concerne a esta pesquisa, em específico, trata-se de um trabalho polifônico e, com certeza, escaparam nomes na hora de relacionar todas as vozes que se cruzaram na composição desse texto. Relaciono, abaixo, aqueles que a memória me permitiu captar...

Um trabalho como esse só é possível com a ajuda de muita, muita gente e, dessa forma, agradeço às diversas pessoas pelos mais variados motivos, pelo incentivo, apoio, fornecimento de materiais, pelos espaços de interlocução proporcionados (virtuais e reais), pela postura de servir e de colaborar com o meu crescimento.

A Deus, em quem eu busco e recebo orientação e paz.

À minha mãe, que nunca colocou limite aos meus sonhos.

À minha família pelo apoio, compreensão, paciência e por saber perdoar as minhas muitas ausências ao longo desta pesquisa.

Aos meus professores do Centro de Estudos de Línguas (CEL) do Estado de São Paulo: João, Fabíola, Rejane, Silvia; que mediaram o meu primeiro encontro com a língua espanhola.

Aos meus professores do curso de Letras da Universidade Estadual Paulista "Júlio de Mesquita Filho", UNESP, campus de Assis, e em especial aos da área de espanhol: Antonio R. Esteves, Ester M. Rojas Osorio, Heloísa Costa Milton, Kelly Cristiane H. P. de Carvalho, Maria de Lourdes Otero Brabo Cruz, Nanci Lopes; por terem - cada um a sua maneira acrescentado novas entonações ao meu espanhol e pela forma como fortaleceram minha formação como hispanista e, sobretudo por serem, muitas vezes, mais do que professores.

Aos professores do programa de pós-graduação em educação da Universidade Estadual Paulista "Júlio de Mesquita Filho", UNESP, campus de Marília, com os quais tive a oportunidade de conviver e aprender durante o mestrado: Adrian Oscar D. Montoya, Cyntia Graziella G. Simões Girotto, Dagoberto Buim Arena, Lourdes M. Machado, Maria Sylvia Simões Bueno e, em especial, à Iraíde Marques de Freitas Barreiro; pelas contribuições com a minha formação como educador e pesquisador.

Ao Estado da Paraíba, que acolheu minha família e, em especial, aos meus colegas de trabalho, alunos, monitores, bolsistas e orientandos da Universidade Estadual da Paraíba, UEPB, campus de Monteiro, com quem pude - na maioria das vezes - mais aprender do que ensinar. 
Ao Prof. Afrânio Mendes Catani, por haver - corajosamente - acreditado em mim, me recebido como orientando e pela compreensão e paciência diante das minhas limitações.

À Maria de Lourdes Otero Brabo Cruz que acompanha e medeia o meu desenvolvimento, me ouve e me orienta desde o primeiro ano da graduação e, aos poucos, estendeu este papel aos seus familiares: Tomás Rafael C. Cáceres, Marina Cruz e Christopher Shulby, que sempre contribuíram e contribuem com a minha formação profissional e, além disso, pelo que é mais importante nessa vida: a amizade, o estímulo, o incentivo, o carinho e o afeto constantes para comigo e com minha família.

À Marta Lúcia Cabrera Kfouri Kaneoya, pela contribuição com a minha formação desde os tempos do CEL e pelos momentos de interlocução durante o desenvolvimento desta pesquisa.

À Ana Maria Ferreira Barcelos, pelos momentos on-line de interlocução, pelos muitos e-mails trocados e textos compartilhados.

À Maria Helena Vieira Abrahão, pela postura de servir, pela interlocução, por me apresentar conceitos e bibliografia especializada a respeito da cognição e crenças de professores. Se pude enxergar, aprender e contribuir com algo no universo da pesquisa de crenças que permeiam o complexo processo de ensinar e aprender línguas foi porque me apoiei nos ombros de gigantes, ou melhor, mediadores mais capazes como você. Sempre te admirei muito e fico muito feliz de poder contar com a sua participação em minha trajetória. Muito obrigado por tudo e que você continue iluminando muitos outros caminhos na vida e na pesquisa em linguística aplicada.

A um grande e presente amigo, Manoel Dias Martins, autor - em 1967 - da primeira tese de doutorado com foco no espanhol-língua estrangeira produzida no Brasil no campo linguístico, minha eterna gratidão pelas muitas e constantes contribuições para com a minha formação.

À equipe que me suportou e deu suporte com as traduções e revisões: Cristina L. Martins, Cristina Bongestab, Cristiane Agnes Stolet Correia, Carlos Tito de Sá Cunha, Manoel Dias Martins, meu sincero muito obrigado!

Aos participantes desta pesquisa com os quais, na maioria das vezes, eu mais aprendi do que ensinei.

Às professoras Dras. Maria de Lourdes Otero Brabo Cruz e Maria Helena Vieira Abrahão pelas muitas contribuições ao longo desta pesquisa e pelas sugestões enriquecedoras dadas na ocasião do Exame Geral de Qualificação.

Aos professores que compuseram a banca de defesa - os titulares e os suplentes - pela disponibilidade, paciência, dedicação e pelas contribuições para o aprimoramento do trabalho.

À Penélope e Lisa, incansáveis e fieis companheiras desde a graduação, pela prontidão ao longo das muitas horas e madrugadas diante dos livros e do computador.

Aos amigos, os de perto e os de longe, que nos motiva e acompanha nas oportunidades de aprendizado dessa vida pela amizade e pelos muitos, muitos e muitos favores prestados: Adeilson, Adalgisa, Alexandres, Aliana, Anas, Angélica, Antônia, Carla, Carol, Christian, Cristianes, Cristinas, Danielly, Edilene, Elda, Eliane, Everton, Fabiana, Fernando, Grygena, 
Jane, Joelson, Helen, Kaio, Letícia, Lígia, Lilian, Lourdes, Manoel, Marta, Melânea, Mona, Mônicas, Nefa, Neide, Nenem, Otacílio, Pricila, Renatas, Ricardo, Rocío, Rogério, Ronnie Wesley, Samir, Socorro, Tereza, Tito, Viviane, William, dentre muitos outros.

A você, que está lendo este trabalho, e dando vida ao meu objetivo de contribuir com a construção de conhecimento a respeito do complexo processo de ensino-aprendizagem do espanhol para brasileiros, quer seja pela concordância com nossas proposições, quer seja pelo contraponto tão necessário à construção do conhecimento. 

Quando o homem compreende a sua realidade, pode levantar hipóteses sobre o desafio dessa realidade e procurar soluções. Assim, pode transformá-la com seu trabalho (FREIRE, 1979, p. 30).

Não há ensino sem pesquisa e pesquisa sem ensino. Esses que-fazeres se encontram um no corpo do outro. Enquanto ensino continuo buscando, reprocurando. Ensino porque busco, porque indaguei, porque indago e me indago. Pesquiso para constatar, constatando, intervenho, intervindo educo e me educo. Pesquiso para conhecer o que ainda não conheço e comunicar ou anunciar a novidade (FREIRE, 1996, p.29). 



\section{RESUMO}

SOUZA, Fábio Marques de. O cinema como mediador na (re)construção de crenças de professores de espanhol-língua estrangeira em formação inicial. Tese (Doutorado em Educação: cultura, organização e educação). Faculdade de Educação da Universidade de São Paulo: USP, 2014.

A cultura de aprender e ensinar uma língua estrangeira baseia-se em teorias implícitas que são compostas por fatores como crenças, motivações, memórias, intuições e imagens, dentre outros. Dessa forma, as concepções dos agentes envolvidos na operação global do ensino de línguas exercem profunda influência em todo o processo, já que cada indivíduo, permeado por seu contexto sócio-histórico-discursivo tem suas crenças que embasam as atitudes que norteiam seu comportamento em face do complexo processo de ensino-aprendizagem de línguas. Diante do exposto, esta tese tem como escopo analisar as crenças de professores de espanhol-língua estrangeira (E-LE) em formação inicial, no que diz respeito ao processo de aquisição/aprendizagem da língua estrangeira e ao tratamento unidade e diversidade linguística experimentada pelo espanhol no contexto do ensino desta língua para brasileiros; todas essas reflexões mediadas pelo cinema. Guiamo-nos pela pergunta de pesquisa: se e como se transformam, com a mediação do cinema, as crenças de professores de espanhol em formação inicial acerca do processo de aquisição/aprendizagem da língua estrangeira e do tratamento da unidade e diversidade linguística no ensino de espanhol-língua estrangeira para brasileiros? Trata-se de uma pesquisa qualitativa de cunho etnográfico que se iniciou com a compreensão panorâmica do nosso contexto e, a partir de um grupo focal, traçou um levantamento das crenças dos participantes antes, durante e depois das oportunidades de reflexão propiciadas ao longo do semestre 2013.2, de forma a compreender, no processo, como elas se transformavam ou não por meio das atividades de reflexão propostas. A fundamentação teórica do trabalho está ancorada na perspectiva sociocultural, na formação de professores de línguas, na reflexão a respeito das crenças que permeiam o complexo processo de ensino-aprendizagem de línguas e no papel do cinema como artefato semiótico mediador. A experiência reforçou nossa tese de que o cinema pode contribuir significativamente na formação inicial de professores de espanhol língua-estrangeira promovendo a conscientização linguística a respeito de como se adquire/aprende a língua, bem como possibilitando o trabalho com a variação linguística no ensino deste idioma para brasileiros a partir do cinema, considerado - conforme a perspectiva sociocultural que adotamos - como artefato cultural, ferramenta de mediação simbólica potencializadora do desenvolvimento humano. Concluímos ressaltando a necessidade da difusão do espanhol como língua estrangeira multidimensional e intercultural para brasileiros no âmbito da integração latino-americana, bem como a importância da promoção de espaços de mediação na busca pela transformação de conceitos cotidianos, iluminados por conceitos científicos, possibilitados por meio de atividades que se proponham promover o pensamento reflexivo acerca das crenças, estratégias e atitudes envolvidas no processo de aprendizagem de línguas estrangeiras, almejando potencializar o engajamento do aprendiz e o autogerenciamento da sua aprendizagem.

\section{Palavras-chave}

Espanhol-língua estrangeira (E-LE); Formação de professores; Crenças; Cinema; Filmes; Integração latino-americana. 


\begin{abstract}
SOUZA, Fábio Marques de. Cinema as a mediator in the (re)construction of beliefs of preservice teachers of Spanish as a foreign language. Dissertation $(\mathrm{PhD}$ in Education: Culture, Organization and Education). Faculdade de Educação da Universidade de São Paulo: USP, 2014.
\end{abstract}

The culture of learning and teaching a foreign language is based on implicit theories involving beliefs, motivations, memories, insights and images, among others. In this sense, the concepts of the agents behind the overall operation of language teaching exert a profound influence on the whole process, since each individual, permeated by his socio-historical-discursive context, carries beliefs which ground their attitudes and behavior towards the complex process of teaching/learning languages. Considering the above, this dissertation aims at analyzing the beliefs of pre- service foreign language teachers of Spanish, with regard to their acquisition/learning of the language and the linguistic unit vs linguistic dichotomy experienced by Spanish teachers and learners in Brazil. These reflections will be mediated by the cultural and linguistic diversity of Spanish-speaking films. Our research questions whether the mediation of cinema would contribute to change the beliefs of pre-service teachers of Spanish towards the acquisition/learning of foreign languages and the linguistic diversity in the teaching of Spanish as a foreign language in Brazil. Under the framework of ethnography and qualitative research, our study started by understanding the larger context, and using the focus group methodology, we surveyed the beliefs of the participants before, during and after the reflection encounters offered throughout the second semester of 2013, in order to detect whether these beliefs changed in the course of the discussions. Our theoretical framework is grounded on a sociocultural perspective, and drawn from studies on teacher education, on the role of beliefs on foreign language teaching/learning, and on the role of cinema as an artifact of semiotic mediation. The experience has strengthened our contention that cinema can significantly contribute to pre-service training of teachers of Spanish by promoting language awareness and language learning metacognition. Moreover, films, when regarded as cultural artifacts and tools of symbolic mediation that amplify human development, enable a deeper understanding of cultural and linguistic variation. We conclude by stressing the Spanish should be taught as a multidimensional, intercultural foreign language in Brazil, in the context of Latin American integration. We would also like to emphasize the importance of promoting spaces of mediation, since they may contribute to the transformation of everyday concepts, enlightened by scientific concepts, afforded through activities that promote reflection on the beliefs, attitudes and strategies involved in the process of learning a foreign language, and these may ultimately encourage learners' autonomy and the self-management.

\title{
Keywords
}

Spanish as a Foreign Language (SFL); Teachers education; Beliefs; Cinema; Movies; Latin American integration. 


\section{RESUMEN}

SOUZA, Fábio Marques de. El cine como mediador en la (re)construcción de creencias de profesores de español-lengua extranjera en formación inicial. Tese (Doutorado em Educação: Cultura, Organização e Educação). Faculdade de Educação da Universidade de São Paulo: USP, 2014.

La cultura de aprender y enseñar una lengua extranjera se basa en teorías implícitas que se componen de factores tales como creencias, motivaciones, memorias, intuiciones e imágenes, entre otros. De esta manera, las concepciones de los agentes involucrados en la operación global de la enseñanza de lenguas ejercen profunda influencia sobre todo el proceso, ya que cada individuo, impregnado de su contexto socio-histórico-discursivo, tiene sus creencias que fundamentan las actitudes que guían su comportamiento en virtud del complejo proceso de enseñanza-aprendizaje de lenguas. Frente a lo expuesto, esta tesis tiene como objetivo analizar las creencias de profesores de español-lengua extranjera (E-LE) en su formación inicial, respecto al proceso de adquisición/aprendizaje de la lengua extranjera y al tratamiento de la unidad y diversidad lingüística experimentada por el español en el contexto brasileño de la enseñanza de este idioma; todas esas reflexiones mediadas por el cine. Nos regimos por la pregunta de investigación: ¿si y cómo se transforman, por la mediación del cine, las creencias de profesores de español en formación inicial en cuanto al proceso adquisición/aprendizaje de la lengua extranjera y al tratamiento de la unidad y diversidad lingüística en la enseñanza de español-lengua extranjera a brasileños? Se trata de una investigación cualitativa de carácter etnográfico que comenzó con la comprensión panorámica de nuestro contexto $\mathrm{y}$, a partir de un grupo de enfoque, se trazó un estudio de las creencias de los participantes, antes, durante y después de las oportunidades de reflexión propiciadas a lo largo del semestre 2013.2, con el fin de comprender, en el proceso, cómo ellas se alteraban o no por medio de las actividades de reflexión propuestas. La fundamentación teórica del trabajo está anclada en la perspectiva sociocultural, en la formación de profesores de lenguas, en la reflexión acerca de las creencias que intervienen en el complejo proceso de enseñanza-aprendizaje de lenguas y en el papel del cine como artefacto semiótico mediador. La experiencia comprobado nuestra tesis de que el cine puede contribuir de manera significativa en la formación inicial de profesores de españollengua extranjera promoviendo la concienciación lingüística a propósito de cómo se adquiere/aprende la lengua, y posibilitando el trabajo con la variación lingüística en la enseñanza de este idioma a brasileños a partir de las películas, consideradas -según la perspectiva sociocultural que adoptamos- como artefactos culturales, herramientas de mediación simbólica potenciadoras del desarrollo humano. Podemos concluir subrayando la necesidad de difusión del español como lengua extranjera multidimensional e intercultural a brasileños en el contexto de la integración latinoamericana, además de la importancia de promover espacios de mediación en la búsqueda de la transformación de los conceptos cotidianos, iluminados por conceptos científicos, posibilitados mediante actividades que se propongan a promover el pensamiento reflexivo acerca de las creencias, estrategias y actitudes involucradas en el proceso de aprendizaje de lenguas extranjeras, deseando potenciar el comportamiento y el autocontrol del aprendizaje.

Palabras-clave

Español-lengua extranjera (E-LE); Formación de profesores; Creencias; Cine; Películas; Integración latinoamericana. 


\section{LISTA DE IMAGENS}

\begin{tabular}{|c|c|}
\hline Imagem $1-$ & Localização dos oito campi no mapa do Estado ....................... \\
\hline Imagem $2-$ & Campo semântico das crenças ........ \\
\hline Imagem $3-$ & 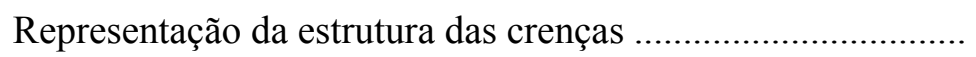 \\
\hline Imagem 4 - & Detalhamento da estrutura central das crenças .......................... \\
\hline Imagem $5-$ & 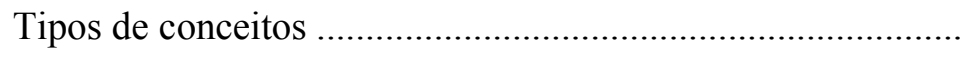 \\
\hline Imagem $6-$ & 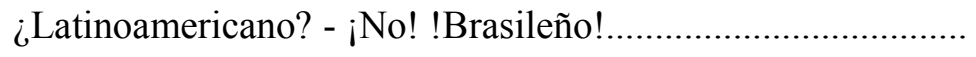 \\
\hline Imagem 7 - & 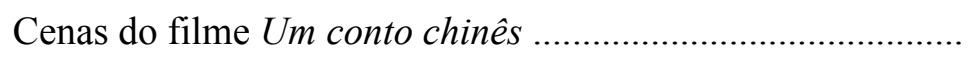 \\
\hline Imagem $8-$ & No momento você não é cidadão de lugar nenhum ................ \\
\hline Imagem $9-$ & 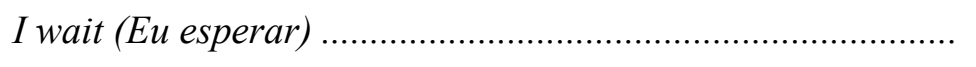 \\
\hline Imagem $10-$ & "Bode, o remédio é 'para o bode', não é 'para o pai', é 'para \\
\hline & 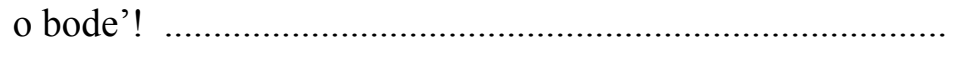 \\
\hline magem $11-$ & Cena do filme paraguaio 7 cajas \\
\hline
\end{tabular}




\section{LISTA DE GRÁFICOS}

Gráfico 1 - Qual país que fala espanhol você gostaria de visitar? 


\section{LISTA DE QUADROS}

Quadro 1- Características, vantagens e desvantagens das três 43 abordagens para o estudo das crenças

Quadro 2 $-\quad$ Instrumentos de pesquisa................................................ 45

Quadro 3- A pesquisa narrativa no contexto da formação de 47 professores de línguas estrangeiras.....................................

Quadro 4 - $\quad$ Metodologia da pesquisa narrativa..................................... 47

Quadro 5 - $\quad$ Material audiovisual utilizado............................................. 49

Quadro 6 - $\quad$ Principais postulados da perspectiva sociocultural ........ $\quad 80$

Quadro 7- Elementos e processos na cognição de professores de 87

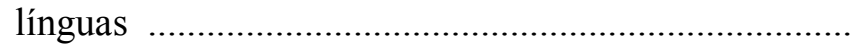

Quadro 8 - Principais características das crenças............................... 93

Quadro 9 - $\quad$ Síntese dos principais conceitos …................................... 108

Quadro 10 - $\quad$ Variedades geográficas do espanhol da América ............ 134

Quadro 11 - $\quad$ As quatro habilidades, simultâneas e integradas ............ 172

Quadro 12 - $\quad$ Elementos de uma situação comunicativa ..................... 194 


\section{LISTA DE TABELAS}

Tabela $1-\quad$ Divisão dos alunos frequentes entre os turnos diurno e noturno $\quad 52$

Tabela $2-\quad$ Divisão dos participantes nos semestres/períodos do curso 53

Tabela 3 - Visões positivas e negativas a respeito da profissão "professor 57 de espanhol"

Tabela 4 - Pontos positivos da profissão "professor de espanhol” 59

Tabela 5 - Pontos negativos da profissão "professor de espanhol” 60

$\begin{array}{lll}\text { Tabela } 6- & \text { Definição para língua espanhola }\end{array}$

Tabela $7-\quad$ O que se sabe quando se sabe uma língua estrangeira 63

Tabela 8 - A motivação para estudar E-LE $\quad 64$

Tabela 9- Qual país que fala espanhol você gostaria de visitar? 65 


\section{LISTA DE ABREVIATURAS E SIGLAS}

CEL: Centro de Estudos de Línguas.

E-LE: Espanhol Língua Estrangeira.

LA: Linguística Aplicada.

LE: Língua Estrangeira.

LM: Língua Materna.

OCEM: Orientações Curriculares para o Ensino Médio (MEC, 2006).

PCNs: Parâmetros Curriculares Nacionais.

TCC: Trabalho de Conclusão de Curso. 


\section{CONVENÇÕES PARA TRANSCRIÇÃO ${ }^{1}$}

$\begin{array}{cl}(()) & \text { Comentário do pesquisador } \\ (+) & \text { Pausa } \\ {[[]]} & \text { Falas simultâneas } \\ \text { “ } \% & \text { Citação, discurso indireto ou referência a outras falas } \\ / & \text { Truncamentos bruscos } \\ ? & \text { Entonação ascendente ou pergunta } \\ ! & \text { Enfase/Exclamação } \\ (*) & \text { Uma palavra incompreensível } \\ (* *) & \text { Duas palavras incompreensíveis } \\ (* * *) & \text { Trecho incompreensível } \\ \text { MAIÚSCULA } & \text { Ênfase }\end{array}$

${ }^{1}$ Elaboradas a partir de Marcuschi (2004). 



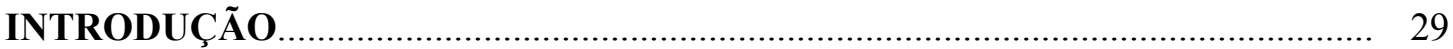

Justificativa e relevância da pesquisa............................................................... 32

Objetivo e perguntas de pesquisa................................................................. $\quad 35$

Organização da tese............................................................................................ 36

1 PROCEDIMENTOS METODOLÓGICOS E PANORAMA DO CONTEXTO

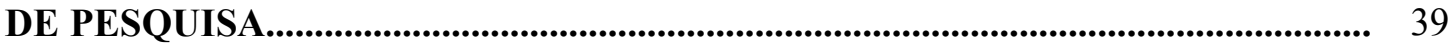

$1.1 \quad$ Procedimentos metodológicos......................................................................... 41

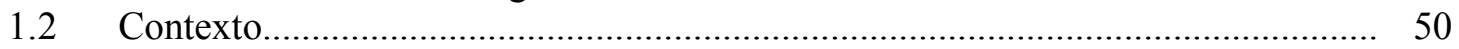

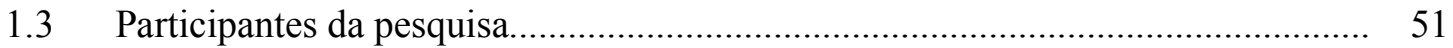

1.4 Panorama do contexto investigado.................................................................... 52

1.5 Perfil sócio-econômico-cultural dos alunos de Letras-Espanhol do Cariri

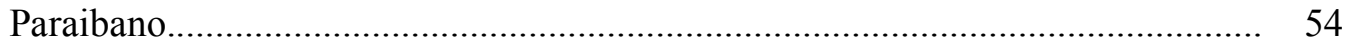

1.6 Estratégias e atitudes em relação ao aprendizado do E-LE ................................. 55

1.7 Expectativas em relação à profissão "professor de espanhol" ............................ 57

1.8 Crenças a respeito do processo de ensinar e aprender línguas estrangeiras .......... 60

1.9 Crenças acerca da variação linguística experimentada pelo espanhol ................. 65

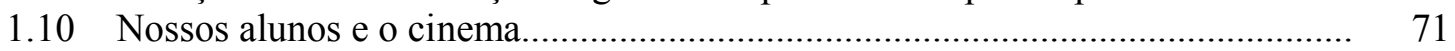

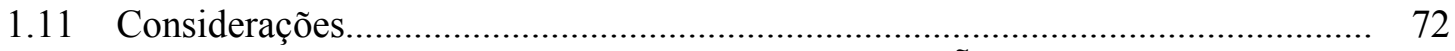

2 CRENÇAS COMO COMPONENTES DA COGNIÇÃO DE PROFESSORES DE ESPANHOL-LÍNGUA ESTRANGEIRA (E-LE) EM FORMAÇÃO INICIAL NUMA PERSPECTIVA SOCIOCULTURAL.......................................................... 75

2.1 Uma perspectiva sociocultural da formação de professores de línguas................. 77

2.2 A cognição de professores de línguas numa perspectiva sociocultural.................. 83

2.3 Por uma definição das crenças...................................................................... 88

2.4 Um perfil das crenças............................................................................... 92

2.5 Potencialidades e limitações para a (re)significação e (re)construção de crenças 95

2.6 Crenças e formação de conceitos: uma aproximação teórica ................................ 100

2.7 Formação de conceitos no contexto do desenvolvimento do professor de língua estrangeira ........................................................................................ 106

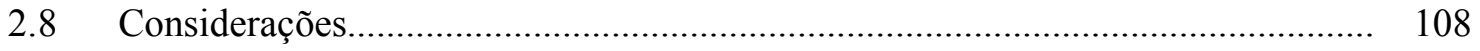

3 ESPANHOL-LÍNGUA ESTRANGEIRA MULTIDIMENSIONAL E INTERCULTURAL PARA BRASILEIROS NO CONTEXTO DA INTEGRAÇÃO LATINO-AMERICANA …..............................................................

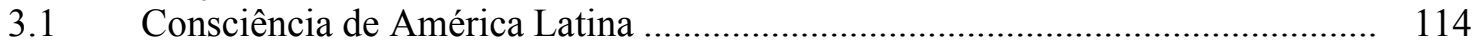

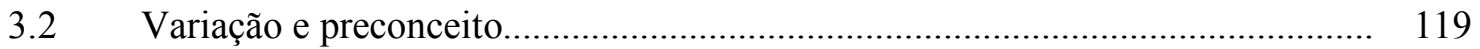

3.3 O lugar das línguas estrangeiras na legislação................................................... 127

3.4 O espanhol da América................................................................................ 131

3.5 Breve apresentação da filmografia utilizada para a reflexão a respeito da unidade e diversidade na e da língua espanhola ............................................... 135

3.5.1 O 'entre-lugar' dos bolivianos em São Paulo .................................................. 135

3.5.2 A vida é uma espuma e deve seguir o exemplo do mar ................................... 137

3.5.3 "Dizem que tem sete línguas a boca do dragão. Eu não sei. Mas me consta que muitas mais línguas têm a boca do mundo e o fogo de suas línguas nos abriga..."

3.5.4 Um passeio pelas lendas e culturas peruanas ............................................ 140 
3.5.5 Manutenção do Status quo?

3.5.6 "Era um homem que tinha tudo: para ele só faltava ser pai, ser filho e sem homem"

3.5.7 Um convite para colocar a mochila nas costas e conhecer a América Latina ....

3.5.8 Política e sexualidade em Morango e chocolate ....

3.6 Considerações

145

4 CONTRIBUIÇÕES DA SÉTIMA ARTE PARA A COMPREENSÃO E POTENCIALIZAÇÃO DO PROCESSO DE ENSINO-APRENDIZAGEM ...........

4.1 O cinema nos permite outras maneiras de olhar para o mundo e, assim, compreender a nós mesmos

4.2 A sociedade submersa em imagens, sons e movimentos .

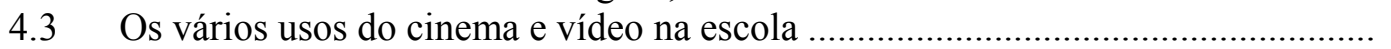

4.4 Pesquisa em educação com base nas artes

4.5 Contribuições da prática cineclubista para a formação humana.

4.6 Algumas pesquisas que utilizam o cinema no ensino de línguas e na formação de professores.

4.7 O papel dos meios alternativos na difusão e no acesso aos produtos audiovisuais

4.8 O exercício da competência intertextual.

4.9 O potencial do cinema como mediador no trabalho com os gêneros orais na aula de E-LE

\section{ALGUMAS REPRESENTAÇÕES CINEMATOGRÁFICAS DO PROCESSO} DE AQUISIÇÃO/APRENDIZAGEM DE LÍNGUAS ESTRANGEIRAS

5.1 Em busca da compreensão do complexo processo de aquisição/aprendizado de línguas estrangeiras

5.2 Algumas representações cinematográficas do processo de

5.2.1 Albergue Espanhol: em busca do perfil intercultural, o aluno como etnógrafo

5.2.1.1 Um mundo em ebulição e a disposição ao novo ..............................................

5.2.1.2 Línguas em contato podem gerar conflitos: é preciso saber administrá-los......

5.2.1.3 A Espanha que não fala espanhol

5.2.1.4 O "bar" como local privilegiado para a aquisição da linguagem coloquial ......

5.2.1.5 Desafios

5.2.2 Multiculturalismo e o processo de aquisição de línguas estrangeiras representado em Um conto chinês ...

5.2.2.1 Não falam a mesma língua... e agora?

5.2.2.2 A subcompetência estratégia para compensar desarranjos na comunicação ....

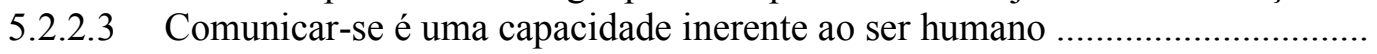

5.2.2.4 Reflexões

5.2.3 O terminal como porta aberta à aquisição de uma nova língua ........................

5.2.4 "Los Angeles tem 48\% de hispânicos... Durante seis anos não nos aventuramos para além da nossa comunidade... estávamos a salvo e felizes"

5.2.5 Numa grande cidade em que, normalmente, ninguém se importa com ninguém, ele se permitiu uma experiência intercultural

5.2.6 Cada vez mais eles conversam, cada um em seu idioma, já que nenhum dos dois fala bem a língua inglesa 


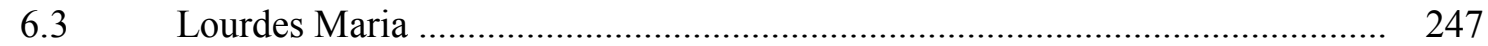

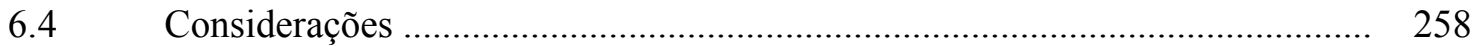

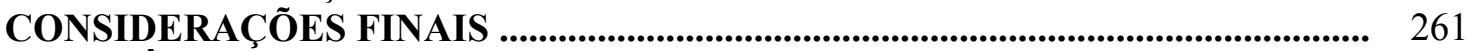

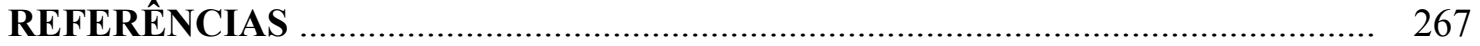



INTRODUÇÃO

\section{LÍNGUA ESPANHOLA E CINEMA: A APROXIMAÇÃO DE DUAS PAIXÕES E O DESVELAR DE UMA PROPOSTA DE PESQUISA}


No que concerne à situação da língua espanhola em território brasileiro, vivemos um momento de crescimento da demanda por cursos e insumos relacionados ao processo de ensino-aprendizagem deste idioma. Da década de 1980 para cá, as políticas para a promoção do ensino do espanhol no Brasil nos colocaram diante de um cenário singular para a oferta desta língua estrangeira, o que pode ser comprovado pela publicação da Lei n. ${ }^{\circ} 11.161$, de 5 de agosto de 2005, que torna obrigatória a oferta desse idioma no Ensino Médio.

Foi no cerne dessa efervescência que iniciei, em 1994, como aluno de um Centro de Estudos de Línguas (CEL) do Governo do Estado de São Paulo, minha trajetória pela língua de Cervantes e esta caminhada se estende até hoje: licenciei-me em Letras (Português/Espanhol) pela UNESP - Universidade Estadual Paulista "Júlio de Mesquita Filho”, Faculdade de Ciências e Letras de Assis-SP e defendi - em julho de 2009 - dissertação de mestrado com foco nas políticas linguísticas, difusão do espanhol e formação de professores para este idioma em território brasileiro, no programa de pós-graduação em Educação da UNESP, Faculdade de Filosofia e Ciências de Marília-SP.

Naquela ocasião, minha pesquisa (SOUZA, 2009) destacava a necessidade da difusão do espanhol enquanto língua multidimensional e intercultural, o que não vem ocorrendo até hoje nas tomadas de decisão da maior parte dos Estados brasileiros. No caso de São Paulo, que foi o foco da investigação, constatei que o Estado: a) utiliza-se da ausência de ações como estratégia política para a apropriação da Lei $11.161 / 2005$; b) ignorava os documentos oficiais da década de 1980 que preconizavam a difusão do espanhol para a integração latinoamericana e acabava outorgando seu papel a organismos exteriores, o que culmina na ausência de uma real política de integração com a América Latina.

Nas considerações finais da minha dissertação, sinalizei que, apesar de o Estado parecer imune às manifestações, minha pesquisa foi concluída como mais uma forma de resistência de uma memória para que o espanhol seja difundido como língua multidimensional e intercultural no território brasileiro, deslocando-se do lugar de língua parecida, logo fácil, e que não precisa ser estudada e ocupando o espaço de uma possibilidade a mais de subjetivação, de fazer-se outro, fortalecendo nossa identidade latino-americana.

As atividades acadêmicas e as vivências em diversas modalidades de ensino de espanhol em variados contextos culminaram, em 2011, com o meu ingresso - como professor efetivo da área de Língua Espanhola - no curso de Letras da Universidade Estadual da Paraíba, UEPB. Neste mesmo ano, fui aprovado na seleção de ingresso e me matriculei no programa de pós-graduação da Faculdade de Educação da Universidade de São Paulo com a meta de desenvolver esta tese de doutorado que aproxima duas de minhas paixões: a língua 
espanhola e o cinema. Ao longo do doutorado, buscando ampliar minha formação e compreender melhor o complexo processo de ensino aprendizagem, licenciei-me em Pedagogia pela Universidade Nove de Julho.

Ao longo do tempo, minha relação com a sétima arte - que já fazia parte da minha trajetória há muitos anos, mas de forma despretensiosa, como entretenimento nas idas ao cinema ou em casa, entre familiares e amigos, em suporte DVD, passou a ser aprimorada.

Durante minha experiência como aluno, professor, pesquisador e formador de professores de espanhol-língua estrangeira (E-LE), muitas inquietações têm visitado minha prática e sempre tenho tentado compreender como e quando se adquire/aprende ${ }^{2}$ e porquê, em algumas situações, não se adquire/aprende. Enfim, quais são as crenças, estratégias, hábitos e atitudes dos alunos que influenciam no processo, bem como quais ações são possíveis de, enquanto mediador, desenvolver para potencializar o ensino-aprendizagem.

Dessa forma, esta tese tem como escopo analisar as crenças de professores de espanhol - língua estrangeira (E-LE) em formação inicial, no que diz respeito ao processo de aquisição/aprendizagem da língua estrangeira e ao tratamento unidade e diversidade linguística experimentada pelo espanhol no contexto do ensino desta língua para brasileiros; todas essas reflexões mediadas pelo cinema.

Em outras palavras, defendo a tese de que é possível trabalhar com a variação linguística experimentada pelo espanhol-língua estrangeira (E-LE) e com a conscientização acerca do aprendizado deste idioma com professores brasileiros em formação inicial por meio do cinema, considerado - conforme a perspectiva sociocultural - como artefato cultural, ferramenta de mediação simbólica potencializadora do desenvolvimento humano.

Nesta tese, o termo cinema é empregado em sentido amplo, como imagem em movimento, independente do suporte, exceto quando for feita referência explícita nesse sentido. Este texto compartilha, com Macedo (2005), da visão de que o cinema pode assumir vários formatos e ser exibido de diversas formas, por isso se fala hoje em audiovisual, num sentido mais geral, incluindo os vários formatos disponíveis para dispositivos móveis, a película, a fita de vídeo, o disco de DVD, o Blu-ray e outras formas digitais de imagem tão comuns e presentes em nossa contemporaneidade.

Uma vez apresentada, brevemente, a minha trajetória, bem como a minha relação com a língua espanhola e o cinema, de forma a aproximar essas duas paixões no desvelar desta

\footnotetext{
${ }^{2}$ Os termos aquisição e aprendizagem serão utilizados nesta tese indistintamente, apesar de sabermos das discussões em torno desta temática, bem como da dicotomia estabelecida por Krashen (1982).
} 
pesquisa, os próximos itens utilizarão a primeira pessoa do plural, que julgo ser mais adequada para o texto acadêmico.

\section{Justificativa e relevância da pesquisa}

As crenças subsidiam nossas tomadas de decisão, já que exercem papel crucial em nossas ações em torno do complexo processo de ensinar e aprender línguas. Neste sentido, propiciar momentos de explicitação e reflexão compartilhada acerca das crenças dos envolvidos permite uma revisão das finalidades, componentes e atitudes e, dessa forma, pode propiciar a potencialização do ensino-aprendizagem.

A relevância de se trabalhar com estas questões na formação de professores de línguas consiste no fato de propiciar a tomada de consciência, que seria o primeiro passo rumo a uma prática transformadora como aprendiz e, consequentemente como professor, a partir da mudança nas ações e, consequentemente, nas crenças que sustentam estas ações.

Barcelos (2013c) relata que desde meados da década de 1990, a investigação de crenças sobre o ensino e a aprendizagem de línguas tem se tornado crescente tema de dissertações, teses, livros e capítulos de livros no Brasil e no mundo. A pesquisadora argumenta que, entretanto, a maior parte das investigações tem como objeto a língua inglesa. Dessa forma, pesquisas como a nossa, que abordam a (re)construção de crenças dos participantes a respeito de como se adquire/aprende uma língua estrangeira, bem como no que concerne à variação linguística $n a$ e da língua espanhola, desde uma perspectiva sociocultural, podem apresentar interessantes contribuições para a área.

A questão da variação é bem explorada em estudos teóricos, em compêndios de sociolinguística. Nossa intenção é averiguar, em um contexto empírico de formação de professores, quais as crenças que os participantes têm acerca do processo de aquisição/aprendizagem da língua, bem como a maneira como os envolvidos percebem a questão da variação linguística experimentada pelo espanhol e as possíveis contribuições do cinema como artefato semiótico mediador dessas reflexões e do tratamento da variação no contexto do ensino deste idioma para falantes do português do Brasil.

Neste sentido, cabe destacar que até o momento ainda não tivemos contato com nenhum trabalho que, filiado à perspectiva sociocultural, utilize o cinema - material culturalmente construído - como mediador para o trabalho com crenças a respeito da aquisição/aprendizagem da língua estrangeira e com o tratamento da variação linguística no ensino da língua espanhola para brasileiros. 
Laseca (2008) e Cañas (2012) relatam que o ensino da língua espanhola no Brasil apresenta uma história incipiente no âmbito universitário. Temos que aclarar que nas universidades do sul e sudeste do país, os estudos de espanhol vêm se desenvolvendo há muitos anos; já nas universidades da região norte e nordeste a temática tem ganhado um espaço no âmbito acadêmico muito recentemente, contando apenas com pouco menos de uma década de vida.

No Estado da Paraíba, os estudos universitários de espanhol ainda se encontram em um estágio inicial. As três universidades principais (UFPB, UFCG e UEPB) vêm implantando a graduação em Letras-Espanhol de forma efetiva desde o ano de $2006^{3}$.

Até 2006, o E-LE tinha sido promovido apenas por meio de cursos de idiomas, oferecidos na Central de Línguas do Estado da Paraíba, nos cursos de extensão das universidades e nas diversas escolas privadas da região.

Diante da escassez de estudos hispânicos nas universidades do Estado da Paraíba, contexto em que se desenvolve nossa investigação, entendemos que este trabalho pode ser direcionado para fortalecer a formação dos estudantes da graduação, considerando que esta ação pode ecoar na comunidade, proporcionando a melhoria da qualidade educativa, já que nossos alunos são professores em formação e, posteriormente, a maioria dedicar-se-á à prática docente, o que pressupõe, de forma simultânea, o desenvolvimento da pesquisa como parte de um ciclo formativo e do desenvolvimento de uma consciência linguística e pedagógica. Dessa forma, a melhora que almejamos refere-se, principalmente, a um avanço na compreensão das atitudes que movimentam a prática educativa no âmbito linguístico.

Diante do exposto, podemos afirmar que o Estado da Paraíba está dando os primeiros passos na formação de professores de E-LE, o que vem a ser mais uma justificativa para a relevância da nossa pesquisa, principalmente se pensarmos que, ao contrário da UFPB, que está na capital (João Pessoa), e da UFCG e do Campus I da UEPB, que estão em Campina Grande, cidade que conta com 400.000 habitantes, o curso no qual trabalhamos e desenvolvemos esta pesquisa está localizado no interior do Estado, numa região rural com pouco mais de 30.000 habitantes. Isto acaba dificultando as oportunidades cotidianas de contato com a língua espanhola em situações reais de uso e, diante disso, nossa proposta de promover atividades com a mediação do cinema para apresentar mostras verossímeis de língua produzidas de forma contextualizada e sem manipulações com fins didáticos torna-se ainda mais relevante.

\footnotetext{
${ }^{3}$ No caso da UFCG, o curso está, de fato, funcionando desde 2011-2.
} 
A partir da constatação do desenvolvimento do espanhol no território brasileiro, ainda incipiente em muitas áreas do país, faz-se necessário pensar e definir a formação nesta área dentro do âmbito universitário, diferenciando a modalidade formativa acadêmica de outras possíveis e existentes (cursos de idiomas, cursos de atualização de professores ou mesmo a divulgação oficial da língua e da cultura).

Esta tese se justifica diante desta necessidade de fortalecer a formação universitária nos estudos de espanhol e apresenta contribuição à nossa prática docente como professor de língua espanhola e formador de professores de E-LE, já que nossa pesquisa parte da nossa realidade e os resultados servirão de subsídios para a nossa prática. Em outras palavras, esta pesquisa nos possibilitou conhecer informações importantes acerca do nosso público, o que nos permitirá traçar direcionamentos para nossas ações futuras no ensino, pesquisa e extensão.

Neste sentido, cabe destacar que o curso de Letras-Espanhol do campus VI da UEPB foi criado em 2006, e o Projeto Político Pedagógico começa a ser reestruturado neste momento. Dessa forma, conhecer o perfil, as estratégias e atitudes desses alunos em relação à língua espanhola e ao curso pode nos propiciar direcionamentos interessantes para uma possível reformulação curricular.

Nosso estudo torna-se relevante, também, na medida em que contribui para o crescimento da comunidade discursiva que se dedica a compreender a formação inicial do professor de E-LE no campo da pesquisa em LA. Torna-se fundamental estudar as crenças já que elas influenciarão a relação do aluno (professor em formação) com a língua, seus hábitos e atitudes em relação ao gerenciamento ou não de sua aprendizagem e sua constituição como profissional. Uma vez terminada a formação inicial propiciada pelo curso de graduação, as crenças continuarão influenciando sua atuação profisssional durante toda a sua trajetória e permearão suas possíveis ações como professor, coordenador, elaborador de testes oficiais, programas de ensino, material didático e políticas públicas para o ensino de línguas, dentre outras.

O curso de Letras-Espanhol do campus VI da UEPB funciona em dois turnos (matutino e noturno), com duas entradas anuais, somando 50 alunos por ano. Uma entrada ocorre no primeiro semestre e outra no segundo semestre. O curso iniciou em 2006, de forma que, em 2009, formamos a primeira turma e, consequentemente, tivemos formatura em 2010, 2011 e 2012, ou seja, neste período tivemos o ingresso de 200 alunos, porém só 60 estudantes se formaram, o que indica um índice de $70 \%$ entre reprovação, evasão, transferências e trancamentos. 
Diante deste alto índice de alunos que ingressam na universidade e não se formam, a partir dos dados levantados nesta pesquisa pretendemos traçar planos de ação, incluindo cursos de extensão que trabalhem a conscientização linguística acerca dos comportamentos, hábitos e atitudes que influenciam na forma como se estuda e se aprende uma língua estrangeira, com vistas a fomentar o engajamento e a autoaprendizagem, contribuindo assim para a redução das taxas de reprovação e de evasão dos participantes envolvidos.

\section{Objetivo e perguntas de pesquisa}

Tomando como ponto de partida nosso objetivo de analisar as crenças de professores de espanhol em formação inicial acerca de como se adquire/aprende o espanhol como língua estrangeira e do tratamento da unidade e diversidade linguística no ensino deste idioma para brasileiros, emergiu como pergunta de pesquisa:

- Se e como se transformam, com a mediação do cinema, as crenças de professores de espanhol em formação inicial acerca do processo de aquisição/aprendizagem da língua estrangeira e do tratamento da unidade e diversidade linguística no ensino de espanhol-língua estrangeira para brasileiros?

Nosso processo investigativo se iniciou com a compreensão panorâmica do nosso contexto e, a partir de um grupo focal, traçou um levantamento das crenças dos participantes antes, durante e depois das oportunidades de reflexão propiciadas ao longo do semestre 2013.2, de forma a compreender, no processo, como elas se transformam ou não por meio das atividades de reflexão propostas.

Dito de outra maneira, investimos na ampliação da capacidade reflexiva do aluno (professor em formação inicial) enquanto homem complexo e promovemos espaços de mediação na busca pela transformação de conceitos cotidianos, iluminados por conceitos científicos, oportunizados por meio de uma série de atividades que promoveram o pensamento reflexivo acerca das crenças, estratégias e atitudes envolvidas no processo de aquisição/aprendizagem de línguas estrangeiras, almejando potencializar a autonomia e o autogerenciamento da aprendizagem.

Diante do exposto, duas perguntas se desdobram de nosso questionamento principal:

- A partir do discurso dos participantes, quais são os indícios da influência dessas crenças na forma como eles se engajam em sua formação profissional? 
- Quais as contribuições do cinema, enquanto artefato semiótico mediador, no processo de desenvolvimento do aprendiz reflexivo?

\section{Organização da tese}

Esta tese de doutoramento está organizada em seis capítulos, precedidos por esta introdução. A introdução "Língua espanhola e cinema: a aproximação de duas paixões e o desvelar de uma proposta de pesquisa" apresenta a formulação do tema, a justificativa e relevância, bem como nossas perguntas de pesquisa.

No primeiro capitulo, apresentamos nossos procedimentos metodológicos, os materiais e métodos utilizados e um panorama do nosso contexto de pesquisa. Trata-se de uma pesquisa qualitativa de cunho etnográfico que busca ir além da mera descrição das crenças dos participantes, de forma a traçar um panorama e, a partir dele, posteriormente tentar compreender as origens dessas crenças, as influências do contexto e o potencial do cinema como artefato semiótico mediador da reconstrução ou ressignificação delas.

O segundo capítulo parte do pressuposto de que a cultura de aprender e ensinar uma língua estrangeira baseia-se em teorias implícitas que são compostas por fatores como crenças, motivações, memórias, intuições e imagens, dentre outros e que as concepções dos agentes envolvidos na operação global do ensino de línguas exercem profunda influência em todo o processo, já que cada indivíduo, permeado por seu contexto sócio-histórico-discursivo tem suas crenças que embasam as atitudes que norteiam seu comportamento em face do complexo processo de ensino-aprendizagem de línguas. Dessa forma, nosso trajeto está dedicado à compreensão das crenças como um elemento da cognição de professores, compreendida desde a perspectiva sociocultural adotada para esta tese.

O terceiro capítulo está dedicado à compreensão do linguístico como elemento fundamental no processo de integração regional e, dessa forma, o espanhol é pensado como língua estrangeira multidimensional e intercultural para brasileiros de forma a promover uma integração que considere a América Latina como uma construção cultural, histórica, política e não somente uma construção geográfica.

No quarto capitulo, "Contribuições da sétima arte para a compreensão e potencialização do processo de ensino-aprendizagem", tecemos considerações acerca das várias vias de estudo com vistas à compreensão do cinema, com foco na indústria, nas artes, nas invenções, no entretenimento e ressaltamos seu potencial para propiciar a compreensão da 
cultura escolar, bem como sua capacidade como mediador potencializador do processo de ensino-aprendizagem.

No quinto capitulo apresentamos algumas representações cinematográficas do processo de aquisição/aprendizagem de línguas estrangeiras, comentando algumas das principais teorias/modelos de aquisição/aprendizagem presentes em nosso corpus de análise. Nosso trajeto parte de uma concepção linguística e vai até uma perspectiva sociocultural que incorpora a análise e reflexão a respeito dos hábitos, crenças, estratégias e atitudes envolvidas no processo.

O sexto capítulo apresenta a análise e discussão dos dados coletados ao longo do semestre 2013.2 com um grupo focal de três alunos, de forma a mostrar as contribuições e implicações da experiência para a temática das crenças de professores de E-LE em formação inicial a respeito de como se aprende a língua e em relação ao tratamento da unidade e diversidade deste idioma no ensino do espanhol no Brasil, tendo como pano de fundo o contexto da integração latino-americana.

Finalizamos com um item que traça considerações a respeito do nosso trajeto investigativo de forma a ressaltar os resultados alcançados, as limitações da nossa pesquisa e sugestões para trabalhos futuros. 


\section{CAPÍTULO 1 PROCEDIMENTOS METODOLÓGICOS E PANORAMA DO CONTEXTO DE PESQUISA}


No dia-a-dia da sala de aula (de línguas) há tantas questões urgentes e emergentes que o professor, geralmente, não tem tempo para observar o que acontece e muito menos a sua prática. Problemas surgem, são contornados da melhor forma possível, nada é registrado e a vida segue. É como caminhar todos os dias pela mesma rua. Acabo não vendo a flor que acabou de nascer, e só me dou conta da pedra no meu caminho quando tropeço e, quem sabe, caio (CAVALCANTI, 1999, p. 180).

Fazer pesquisa pode ser um modo de reinventar a vida social e de nos fazer pensar sobre os significados que construímos em nossas práticas e sobre os sofrimentos que acarretam (MOITA LOPES, 2009, p. 18). 


\subsection{Procedimentos metodológicos}

Já é consenso entre os estudiosos que, ao longo do desenvolvimento histórico-social do ser humano, os esclarecimentos mágicos ou de intervenção dos deuses deixaram de dar conta da carência humana em compreender e explicar os fenômenos naturais, dando início ao processo de busca por esclarecer as indagações, de forma a originar o pensamento científico.

Dentre os diversos caminhos disponíveis para o desenvolvimento da pesquisa científica, nesta tese, nos filiamos à pesquisa qualitativa de cunho etnográfico. No intuito de explicar as bases científicas que sustentam nossa escolha, lançamos mão, principalmente, de Lüdke \& André (1986) e André (1995) por nos apresentarem contribuições a respeito da metodologia da pesquisa em educação. Para compreender as potencialidades e limitações da pesquisa etnográfica em sala de aula de língua estrangeira, contamos com Cançado (1991) e, para a compreensão da metodologia da investigação de crenças no contexto do ensinoaprendizagem de línguas, nos apoiamos em Barcelos (2001) e Vieira-Abrahão (2006).

No que concerne ao contexto do ensino-aprendizagem de espanhol-língua estrangeira para brasileiros e da formação de professores nesta área, campo em que atuamos profissionalmente, em meio aos diversos desafios que nos são propostos diariamente, paramos para refletir acerca do que é formar professores de Espanhol-Língua Estrangeira na contemporaneidade, bem como na relação entre nosso contexto local - o cariri ocidental paraibano - e o universo global no qual estes alunos-professores estão inseridos. Dessa forma, esta pesquisa focaliza algumas questões que vinham nos inquietando em nossa prática e, com ela, esperamos trazer um retorno para a nossa atuação profissional.

Dito de outra maneira, esta pesquisa tem como fonte nossas inquietações enquanto professor de línguas e formador de professores e pode resultar em produção de conhecimento para a nossa própria prática bem como para novos questionamentos e temas de investigação.

Há pouco mais de uma década, Cavalcanti (1999) destacava como algo positivo para a área de Linguística Aplicada que já havia, em território brasileiro, muita pesquisa de sala de aula já concluída e sendo realizada, mas que ainda havia muito por fazer. Temos consciência dos benefícios deste processo investigativo para nós próprios e para os alunos envolvidos: durante este procedimento olhamos para nós mesmos, nos questionamos, nos explicamos e, eventualmente, nos reinventamos.

Nossa pesquisa é qualitativa de cunho etnográfico, pois lança mão da etnografia que, etimologicamente, é compreendida como descrição cultural e possibilita uma visão ampla de 
uma unidade complexa como os ambientes de ensino-aprendizagem e as práticas inerentes a estes contextos.

André (1995) argumenta que o que se tem feito é uma adaptação da etnografia à educação, o que leva a concluir que fazemos estudos do tipo etnográfico e não etnografia no seu sentido estrito; justamente por este motivo apresentamos nossa pesquisa como qualitativa de cunho etnográfico e não etnográfica propriamente dita.

$\mathrm{O}$ interesse dos educadores por esse método de pesquisa começou no final dos anos 70, pois se necessitava de um estudo que fosse minucioso no âmbito do dia a dia escolar. Pesquisadores da área destacam que uma característica importante da pesquisa etnográfica é a ênfase no processo, naquilo que está ocorrendo e não no produto ou nos resultados finais. Dessa forma, André (1995) aponta como perguntas geralmente feitas nesse tipo de pesquisa "O que caracteriza esse fenômeno? O que está acontecendo nesse momento? Como tem evoluído?” (p. 29). Tal procedimento é o adotado em nossa tese, já que temos como interesse compreender se e como as crenças se transformam com a mediação do cinema durante as oportunidades de reflexões compartilhadas oferecidas aos alunos do curso de Letras-Espanhol participantes da pesquisa.

Barcelos (2001) apresenta um estado da arte da metodologia de pesquisa das crenças a respeito da aprendizagem de línguas. A autora argumentava que, até aquele momento, a investigação acerca das crenças de ensino-aprendizagem de línguas "tem feito apenas uma descrição dessas crenças, mas não tem tentado entender por que os alunos possuem certas crenças, a sua origem e o papel que algumas delas exercem no processo de aquisição de línguas" (p. 71-72).

A partir das concepções adotadas para as crenças, os métodos de investigação e a relação entre crenças e ação, a autora apresenta e discute as vantagens e as desvantagens de três abordagens de metodologia de pesquisa: normativa, metacognitiva e contextual.

Um resumo das características, vantagens e desvantagens de cada uma dessas abordagens, é apresentado no quadro 1: 


\begin{tabular}{|c|c|c|c|}
\hline & Normativa & Metacognitiva & Contextual \\
\hline Metodologia & $\begin{array}{l}\text { Questionários tipo } \\
\text { Likert-scale. }\end{array}$ & Entrevistas & $\begin{array}{c}\text { Observações, } \\
\text { entrevistas, diários e } \\
\text { estudos de caso. }\end{array}$ \\
\hline $\begin{array}{l}\text { Definição de crenças } \\
\text { sobre } \\
\text { aprendizagem } \\
\text { línguas }\end{array}$ & $\begin{array}{l}\text { Crenças são vistas } \\
\text { como sinônimos de } \\
\text { ideias } \\
\text { concebidas, } \\
\text { concepções errôneas } \\
\text { e opiniões }\end{array}$ & $\begin{array}{l}\text { Crenças são descritas } \\
\text { como conhecimento } \\
\text { metacognitivo: } \\
\text { estável e às vezes } \\
\text { falível que os } \\
\text { aprendizes possuem } \\
\text { sobre aprendizagem } \\
\text { de línguas }\end{array}$ & $\begin{array}{lr}\text { Crenças são vistas } \\
\text { como parte da cultura } \\
\text { de aprender e como } \\
\text { representações } \\
\text { aprendizagem de } \\
\text { uma em } \\
\text { sociedade. }\end{array}$ \\
\hline $\begin{array}{l}\text { Relação entre } \\
\text { crenças e ações }\end{array}$ & 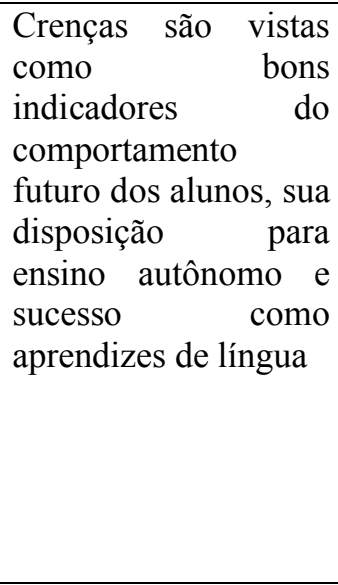 & 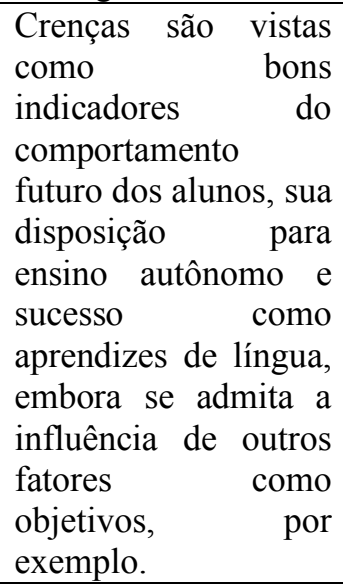 & $\begin{array}{l}\text { Crenças são vistas } \\
\text { como específicas do } \\
\text { contexto, ou seja, as } \\
\text { crenças devem ser } \\
\text { investigadas dentro } \\
\text { do contexto de suas } \\
\text { ações. }\end{array}$ \\
\hline Vantagens & $\begin{array}{l}\text { Permite que as } \\
\text { crenças sejam } \\
\text { investigadas com } \\
\text { amostras grandes, em } \\
\text { épocas diferentes e } \\
\text { em vários contextos } \\
\text { ao mesmo tempo. }\end{array}$ & $\begin{array}{l}\text { Permite que os alunos } \\
\text { usem suas próprias } \\
\text { palavras, elaborem e } \\
\text { reflitam sobre suas } \\
\text { experiências de } \\
\text { aprender. }\end{array}$ & $\begin{array}{l}\text { Permite que as } \\
\text { crenças sejam } \\
\text { investigadas levando } \\
\text { em consideração não } \\
\text { só as próprias } \\
\text { palavras dos alunos, } \\
\text { mas também o } \\
\text { contexto de suas } \\
\text { ações. }\end{array}$ \\
\hline Desvantagens & $\begin{array}{l}\text { Restringe a escolha } \\
\text { dos participantes com } \\
\text { um conjunto de } \\
\text { afirmações } \\
\text { predeterminadas pelo } \\
\text { pesquisador. Os } \\
\text { alunos podem ter } \\
\text { interpretações } \\
\text { diferentes sobre esses } \\
\text { itens. }\end{array}$ & $\begin{array}{lr}\text { As crenças } & \text { são } \\
\text { investigadas } & \text { somente } \\
\text { através } & \text { das } \\
\text { afirmações } & \text { dos } \\
\text { alunos (não } & \text { há } \\
\text { preocupação com a } \\
\text { ação dos alunos). }\end{array}$ & $\begin{array}{l}\text { É mais adequada com } \\
\text { pequeno número de } \\
\text { participantes. } \\
\text { Consome muito } \\
\text { tempo. }\end{array}$ \\
\hline
\end{tabular}

Quadro 1: Características, vantagens e desvantagens das três abordagens para o estudo das crenças. Fonte: Barcelos (2001, p. 82-83).

A abordagem normativa filia-se ao paradigma investigativo positivista, tendo como foco a quantificação dos dados obtidos por meio da aplicação de questionários fechados. Já as abordagens metacognitivas e contextuais pertencem ao paradigma das pesquisas qualitativas que, segundo Vieira-Abrahão (2006) compartilham características comuns: 
a) são naturalistas, ou seja, realizadas dentro de contextos naturais; b) são descritivas, ou melhor, os dados coletados tomam a forma de palavras ou figuras e não de números, c) são processuais, não se preocupando com resultados ou produtos; d) são indutivas, ou seja, os dados são analisados indutivamente, sem buscar evidências que comprovem ou não hipóteses previamente estabelecidas; e) buscam significados, ou melhor, são voltadas para as maneiras como os participantes envolvidos constroem significados de suas ações e de suas vidas. Os pesquisadores qualitativos são aqueles que investigam o que os participantes da pesquisa estão experienciando, como eles interpretam as suas experiências, e como eles próprios estruturam o mundo social na qual vivem (p. 220).

Nos filiaremos, nesta tese, à abordagem contextual de pesquisa das crenças. Nesta perspectiva, elas são investigadas por meio de observações de sala de aula e análise do contexto específico em que os alunos estão envolvidos. Estudos desta natureza não têm como objetivo generalizar acerca das crenças, mas compreendê-las em contextos específicos. Goodwin \& Duranti (1992) definem contexto como um fenômeno socialmente construído e sustentado interativamente, no qual cada ação acrescentada dentro da interação modifica o contexto existente enquanto cria uma nova arena para interações subsequentes.

A abordagem contextual oferece uma definição mais ampla de crenças sobre aprendizagem de línguas, caracterizando-as como dinâmicas e sociais, e propondo uma metodologia diferente para investigá-las. Essa metodologia fornece uma riqueza de detalhes bem mais refinados a respeito dos tipos de crenças do contexto onde essas crenças se desenvolvem, permitindo, assim, uma maior compreensão das crenças e de sua relação com a abordagem de aprender línguas estrangeiras dos alunos (BARCELOS, 2001, p. 82).

Dentre os principais instrumentos que vêm sendo utilizados na pesquisa a respeito das crenças na abordagem contextual e, levando em consideração que na pesquisa qualitativa de cunho etnográfico o investigador deve lançar mão de uma grande quantidade de dados descritivos: situações, pessoas, ambientes, depoimentos, diálogos; nesta tese utilizamos: observações, questionários, atividades, gravação de aulas, $\log s$, histórias de vida e entrevistas, já que "em um desenho de pesquisa, os instrumentos devem ser cuidadosamente selecionados, para que se possam levantar dados suficientes, cuja análise permita atingir os objetivos propostos e responder às perguntas de pesquisa" (VIEIRA-ABRAHÃO, 2006, p. 230). O quadro 2 apresenta uma síntese dos instrumentos utilizados, o objetivo, o momento da pesquisa e por quem foram produzidos: 


\begin{tabular}{|c|c|c|c|}
\hline Instrumento & Finalidade & Quem produziu & $\begin{array}{c}\text { Em qual } \\
\text { momento da } \\
\text { pesquisa }\end{array}$ \\
\hline $\begin{array}{l}\text { Diário de } \\
\text { campo }\end{array}$ & $\begin{array}{l}\text { Registro de sensações, observações } \\
\text { e impressões. }\end{array}$ & Pesquisador & $\begin{array}{l}\text { Durante todo o } \\
\text { processo } \\
\text { investigativo }\end{array}$ \\
\hline Questionário & $\begin{array}{l}\text { Realizar uma sondagem preliminar } \\
\text { que possibilitasse uma visão das } \\
\text { crenças dos participantes de forma } \\
\text { a poder traçar os delineamentos das } \\
\text { atividades subsequentes. }\end{array}$ & $\begin{array}{l}\text { Participantes } \\
(90 \% \text { dos alunos } \\
\text { matriculados no } \\
\text { curso de Letras- } \\
\text { Espanhol) }\end{array}$ & $\begin{array}{l}\text { Dezembro de } \\
2012\end{array}$ \\
\hline Questionário & $\begin{array}{l}\text { Realizar uma sondagem que } \\
\text { possibilitasse uma visão preliminar } \\
\text { das crenças dos participantes }\end{array}$ & $\begin{array}{l}\text { Participantes } \\
\text { (grupo focal) }\end{array}$ & Outubro de 2013 \\
\hline Logs & $\begin{array}{l}\text { Captar sensações e reflexões dos } \\
\text { participantes da forma mais } \\
\text { espontânea possível. }\end{array}$ & $\begin{array}{l}\text { Participantes } \\
\text { (grupo focal) }\end{array}$ & $\begin{array}{c}\text { Durante a } \\
\text { exibição de cada } \\
\text { filme }\end{array}$ \\
\hline Atividades & $\begin{array}{lrrr}\text { Fomentar a } & \text { reflexão } & \text { dos } \\
\text { participantes a } & \text { respeito } & \text { das } \\
\text { temáticas apresentadas nos filmes. }\end{array}$ & $\begin{array}{l}\text { Participantes } \\
\text { (grupo focal) }\end{array}$ & $\begin{array}{l}\text { Antes, durante e } \\
\text { depois da } \\
\text { exibição de cada } \\
\text { filme } \\
\end{array}$ \\
\hline $\begin{array}{l}\text { Gravação das } \\
\text { aulas em áudio }\end{array}$ & $\begin{array}{l}\text { Obter informações a respeito das } \\
\text { reflexões dos participantes durante } \\
\text { as atividades }\end{array}$ & $\begin{array}{l}\text { Participantes } \\
\text { (grupo focal) }\end{array}$ & $\begin{array}{c}\text { Durante o } \\
\text { desenvolvimento } \\
\text { das atividades } \\
\text { durante } 2013.2\end{array}$ \\
\hline Autobiografia & $\begin{array}{l}\text { Expressar elementos significativos } \\
\text { para os participantes a respeito de } \\
\text { suas trajetórias de vida e suas } \\
\text { relações com a escola e com o E- } \\
\text { LE }\end{array}$ & $\begin{array}{l}\text { Participantes } \\
\text { (grupo focal) }\end{array}$ & $\begin{array}{c}\text { Final do } \\
\text { componente } \\
\text { curricular Estágio } \\
\text { Supervisionado } \\
\text { IV }\end{array}$ \\
\hline Entrevista final & $\begin{array}{l}\text { Esclarecimento de dúvidas após a } \\
\text { análise preliminar dos dados }\end{array}$ & $\begin{array}{l}\text { Participantes } \\
\text { (grupo focal) }\end{array}$ & $\begin{array}{c}\text { Após a } \\
\text { finalização das } \\
\text { atividades do } 2 .^{\circ} \\
\text { semestre de } 2013 \\
\end{array}$ \\
\hline
\end{tabular}

Quadro 2: Instrumentos de pesquisa.

No que concerne à observação de aulas, notas de campo e diários, optamos por estas possibilidades pelo fato de nos permitirem documentar de forma sistematizada ações e eventos relevantes para nossa pesquisa. Existem dois tipos de observação, participante e não participante, de acordo com o papel assumido pelo investigador. No caso da nossa tese, tratase da observação participante, já que estivemos o tempo todo observando os envolvidos e nós mesmos como integrantes do contexto pesquisado e mediadores das atividades promovidas. Dito de outra maneira, a observação é chamada de participante porque o pesquisador interage diretamente com o contexto em estudo, afetando-o e sendo mutuamente por ele afetado. 
As entrevistas têm a finalidade de aprofundar as questões e esclarecer os problemas observados. Nesta oportunidade, lançamos mão de entrevistas semiestruturadas, com um roteiro prévio flexível, que pôde ser adequado de acordo com a situação e os objetivos em pauta de forma a possibilitar a voz e os diversos pontos de vista do pesquisador e dos pesquisados acerca da temática em questão.

Embora os questionários estejam originalmente atrelados à abordagem normativa de investigação das crenças, enquadrada num paradigma positivista de pesquisa que se volta para a quantificação, isso não significa que não possam mais ser utilizados quando há o predomínio de pesquisas qualitativas nas quais as crenças não mais são vistas como estáticas, mas dinâmicas e emergentes (VIEIRA-ABRAHÃO, 2006). Dessa forma, considerando que nenhum instrumento isolado é suficiente, lançamos mão dos questionários em nossa pesquisa, já que esses instrumentos foram utilizados de forma a obter dados que puderam ser utilizados na triangulação com dados contextuais obtidos por meio de outros instrumentos como observação, diários, notas de campo, logs, entrevistas e histórias de vida.

Quanto aos logs, compartilhamos da definição apresentada por Wallace (1998): "notas de campo que podem ser altamente estruturadas dentro de um formato específico. Passaremos a chamá-las de registros, diferenciando-os assim das notas de campo mais fluídas e ad hoc" (p. 54). Dito de outra forma, compreenderemos, nesta tese, os logs como registros breves de impressões dos participantes durante a exibição dos filmes, que foram anotados em um diário de bordo.

Utilizamos também autobiografias dos participantes. A pesquisa narrativa possibilita aos envolvidos compartilhar suas experiências vividas na e pela linguagem, de maneira individual e coletiva, tornando-se sujeitos de vidas historiadas e impondo-se como pessoas do discurso.

A pesquisa narrativa está sendo cada vez mais utilizada em estudos de experiência no campo da educação. Apresenta uma longa tradição científica tanto no campo da educação como fora dele. (...) O estudo da narrativa é, portanto, o estudo das maneiras como os seres humanos vivenciam o mundo. Esta noção geral se traduz no conceito de que a educação constitui a construção e reconstrução de histórias pessoais e coletivas; professores e alunos são contadores e personagens de suas próprias histórias e das histórias de terceiros (CONNELLY \& CLANDININ, 1990, p. 30).

O quadro 3 sintetiza as principais contribuições desta modalidade de pesquisa no contexto da formação de professores de línguas estrangeiras:

\footnotetext{
${ }^{4}$ No original: "Field-notes can be kept in highly- structured ways, following a particular format. We call such records logs to distinguish them from the more fluid and ad hoc field notes which has just been described".
} 
A PESQUISA NARRATIVA NO CONTEXTO DA FORMAÇÃO DE PROFESSORES DE LÍNGUAS ESTRANGEIRAS

\section{QUALIDADES}

"Nesta modalidade de pesquisa, os
professores são, ao mesmo tempo,
agentes e objetos de investigação"
(TELLES, 1999, p. 81)
"A narrativa é a estrutura
fundamental da experiência humana"
(CLANDININ \& CONNELLY,
1990, p.12)
"A metodologia da pesquisa narrativa
é apropriada para lidar com questões
da trajetória da formação pessoal,
acadêmica e pedagógica dos
professores, de seu conhecimento
pessoal-prático e, também, com
questões relativas à experiência dos
participantes com a língua (materna
ou estrangeira)" (TELLES, 1999, p.
89)
Qual

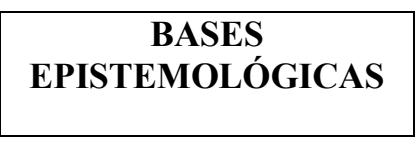

Pesquisa qualitativa e humanística na formação de professores de Língua Estrangeira;

Estabelece espaços para emancipação, autonomia, construção conhecimento e da identidade profissional do "eu professor" (self-asteacher)

\section{INSTRUMENTOS DE COLETA}

Quadro 3: A pesquisa narrativa no contexto da formação de professores de línguas estrangeiras. Fontes: Connelly \& Clandinin (1990); Telles (1999). Adaptação e compilação nossa.

Para os pesquisadores da área (ERICKSON, 1986; CONNELLY \& CLANDININ, 1990; TELLES, 1999), o que coletamos no campo não são dados, mas material documentário que, por sua vez, será um gerador de dados (visto que criamos significados a partir deste mesmo material), conforme apresentado no quadro 4:

\begin{tabular}{|c|c|c|}
\hline História & $\Rightarrow$ & Narrativa \\
\hline Descrição/Narração temporal dos fatos; & $\Rightarrow$ & $\begin{array}{c}\text { Relato reflexivo das histórias previamente } \\
\text { narradas; }\end{array}$ \\
\hline Participantes contam estórias; & $\Rightarrow$ & Pesquisadores escrevem narrativas; \\
\hline Textos de campo; & $\Rightarrow$ & Textos de pesquisa; \\
\hline O que é coletado; & $\Rightarrow$ & Material escrito pós-coleta; \\
\hline Objeto da pesquisa* & $\Rightarrow$ & Método da pesquisa* \\
\hline Relata/Descreve fatos. & $\Rightarrow$ & Constrói significado/Estabelece relações. \\
\hline
\end{tabular}


Conforme apresentado, as histórias de vida coletadas se constituem na narração temporal dos fatos significativos para os participantes e, depois de analisadas à luz das teorias que comungamos, constituem narrativas, isto é, relatos reflexivos de construção de significados de forma a estabelecer relações entre o que foi relatado/descrito.

Quanto à forma de análise dos dados reunidos, nesta pesquisa, trabalhamos a partir de uma linha de descrição e interpretação, o que implica dialogar com as tradições fenomenológica e hermenêutica, principalmente com sua trajetória no campo da pesquisa em educação. Os procedimentos tomados para interpretar, isto é, produzir significados a partir dos dados coletados, são de base qualitativa.

Diante dos dados obtidos, seguimos os passos sugeridos por Van Manen (2003), a saber: a) primeira leitura completa de todos os dados; b) segunda leitura sublinhando com um marcador de textos as partes mais importantes que o pesquisador vai encontrando tendo em mente as perguntas de pesquisa; c) terceira leitura (tematização), "segmentando" o texto conforme os temas vão surgindo; d) quarta e, se necessário, próximas leituras, buscando temas que são recorrentes, que se repetem, de forma a apresentar uma lista de categorias de análise.

Levando-se em consideração que os dados são mediados pelo instrumento humano, o pesquisador, o corpus reunido foi triangulado e analisado à luz de teorias interpretativistas de cunho qualitativo, para que assim pudéssemos considerar as várias subjetivações que se elaboram no processo de ensino-aprendizagem, envolvendo as opiniões de todos os participantes já que uma característica da etnografia é a "preocupação com o significado, com a maneira própria com que as pessoas veem a si mesmas, as suas experiências e o mundo que as cerca. O pesquisador deve tentar apreender e retratar essa visão pessoal dos participantes" (ANDRÉ, 1995, p. 29).

Nosso plano de trabalho foi aberto e flexível, de forma que os focos da investigação pudessem ser constantemente revistos; as técnicas de coleta reavaliadas, os instrumentos reformulados e os fundamentos teóricos repensados. Dito de outra maneira, nosso desenho de pesquisa sofreu ajustes de forma a ser remodelado para dar conta da complexidade do fenômeno do ensino-aprendizagem de línguas em observação. Nosso embasamento teóricometodológico foi (re)pensado ao longo do processo, de forma a buscar a formação dos participantes envolvidos. Conforme ressalta Cavalcanti (1999), o ponto de partida para isso seria a reflexão, teoricamente embasada, sobre a prática, segundo ela, "a partir daí o caminho está aberto para mudanças que são sempre difíceis e que envolvem um constante ir e vir” (p. 181). 
O quadro 5 reúne o material audiovisual utilizado como mediador das reflexões desenvolvidas:

\begin{tabular}{|c|c|}
\hline \multicolumn{2}{|c|}{ Filmes utilizados nas atividades desenvolvidas ao longo do semestre $2013.2^{5}$} \\
\hline $\begin{array}{c}\text { Aquisição/aprendizagem da língua } \\
\text { estrangeira }\end{array}$ & $\begin{array}{l}\text { Unidade e diversidade no universo da } \\
\text { língua espanhola }\end{array}$ \\
\hline $\begin{array}{l}\text { Albergue Espanhol (KLAPISCH, C. [Dir.] } \\
\text { L'Auberge espagnole. } \\
\text { Espanha/França: 2003); } \\
\text { O Terminal (SPIELBERG, Steven [Dir.] The } \\
\text { Terminal. DVD, EUA: 2004); } \\
\text { Espanglês (BROOKS, James L. [Dir.] } \\
\text { Spanglish. DVD, EUA: 2004); } \\
\text { Um conto chinês (BORENSZTEIN, } \\
\text { Sebastián [Dir.] Un Cuento Chino. DVD, } \\
\text { Argentina: 2011); } \\
\text { O Visitante (MCCARTHY, Thomas [Dir.] } \\
\text { The visitor. DVD, EUA, 2007); } \\
\text { Mil anos de orações (WANG, Wayne [Dir.] } \\
\begin{array}{l}\text { Mr. Shi, DVD, EUA, 2007). }\end{array}\end{array}$ & $\begin{array}{l}\text { "Dia da Independência", episódio da Série } \\
\text { "Destino: São Paulo" (GABASSI, Alex } \\
\text { [Dir.] HBO Brasil, 2012); } \\
\text { E sua mãe também (CUARÓN, Alfonso } \\
\text { [Dir.] Y tu mamá también. DVD, México, } \\
\text { 2001); } \\
\text { cajas (MANEGLIA, Juan Carlos; } \\
\text { SCHEMBORI, Tana [Dir.] } 7 \text { cajas. DVD, } \\
\text { Paraguai, 2012); } \\
\text { El misterio del Kharisiri (VALLEJO, Henry } \\
\text { [Dir.] El misterio del Kharisiri. DVD, Perú, } \\
\text { 2004). } \\
\text { Machuca (WOOD, Andrés [Dir.] Machuca. } \\
\text { DVD, Chile, 2004); } \\
\text { Ofilho da noiva (CAMPANELLA, Juan José } \\
\text { [Dir.] El hijo de la novia. DVD, Argentina, } \\
\text { 2001); } \\
\text { Diários de motocicleta (SALLES, Walter } \\
\text { [Dir.] The Motorcycle Diaries. DVD, } \\
\text { Argentina, 2004); } \\
\text { Morango e Chocolate (GUTIÉRREZ ALEA, } \\
\text { Tomás; TABÍO, Juan Carlos [Dir.] Fresa y } \\
\text { Chocolate. DVD, Cuba: 1993); }\end{array}$ \\
\hline
\end{tabular}

Quadro 5: Material audiovisual utilizado.

Os filmes utilizados como mediadores das reflexões a respeito do tema aquisição/aprendizagem de línguas estrangeiras são analisados no capítulo 5 "principais teorias/modelos de aquisição/aprendizagem de segunda língua/língua estrangeira e algumas de suas representações cinematográficas” desta tese.

\footnotetext{
${ }^{5}$ Ao longo do semestre 2013.2, as atividades foram distribuídas entre dois componentes curriculares e um curso de extensão. A maioria dos filmes foi exibida integralmente.
} 
Nossa escolha por utilizar, no momento de tratar da temática que envolve a unidade e diversidade linguística no universo do espanhol, somente produções que retratam memórias, histórias e territórios latino-americanos, deu-se em função da invisibilidade da América Latina constatada em nossa análise preliminar do contexto, conforme relataremos neste capítulo. O capítulo 3 "espanhol-língua estrangeira multidimensional e intercultural para brasileiros no contexto da integração latino-americana" apresenta uma breve descrição de cada um desses filmes utilizados.

\subsection{Contexto}

O nosso contexto de pesquisa é o curso de Letras-Espanhol, ofertado no Nordeste do Brasil, no Campus VI da Universidade Estadual da Paraíba. A instituição foi criada em 1966, ganhou autonomia em 1996 e, em 2006, implantou o programa de expansão universitária que consolidou a implantação de novos campi:

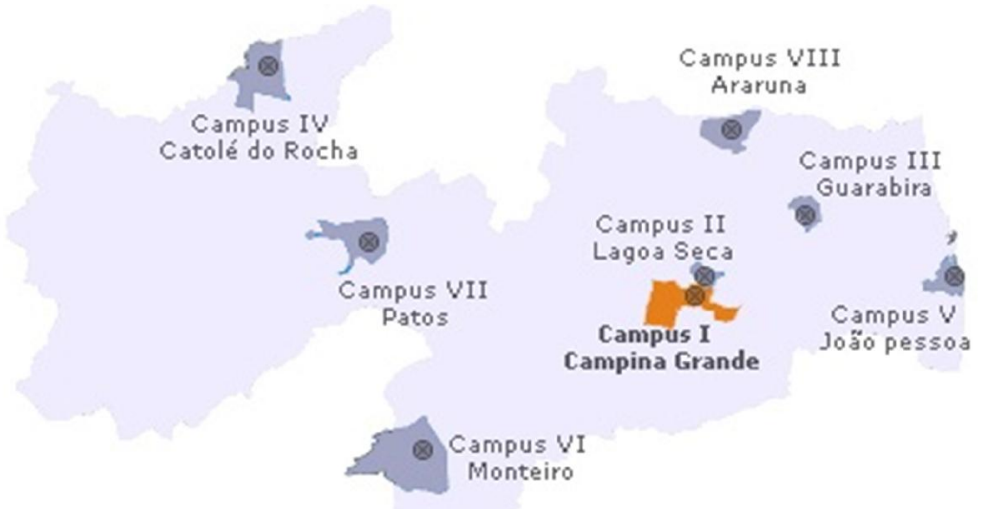

Imagem 1: Localização dos oito campi no mapa do Estado.

Conforme ilustra a imagem 1, atualmente, são 08 (oito) campi, somando a oferta à comunidade de quarenta e quatro cursos de graduação e dezessete programas de pósgraduação stricto sensu. O Campus VI, contexto da nossa pesquisa, foi criado na expansão universitária de 2006 e está localizado na cidade de Monteiro, que fica a 319 quilômetros de João Pessoa, capital do estado e está localizado na microrregião do Cariri Ocidental Paraibano.

Segundo o censo demográfico de 2010 do $\mathrm{IBGE}^{6}$, o município tem uma população aproximada de 30.852 habitantes. Está incluído na área geográfica de abrangência do

\footnotetext{
${ }^{6}$ Disponível em: <http:/cidades.ibge.gov.br/painel/painel.php?codmun=250970 $\geq$ Acesso em: 24 mar. 2014.
} 
semiárido brasileiro, definida pelo Ministério da Integração Nacional em 2005. Esta delimitação tem como critérios o índice pluviométrico, o índice de aridez e o risco de seca.

O campus oferece os cursos de Ciências Contábeis, Licenciatura em Letras- Espanhol, Licenciatura em Letras-Português, Licenciatura em Matemática e três cursos de especialização: I) Estudos Linguísticos e Literários; II) Auditoria e perícia contábil; III) Fundamentos da Educação: práticas pedagógicas interdisciplinares para os professores da rede pública estadual de ensino, numa parceria UEPB/Governo do Estado.

Atualmente, oferece também o curso de Licenciatura em Pedagogia do Plano Nacional de Formação de Professores da Educação Básica - PARFOR, numa parceria UEPB/CAPES/MEC.

No caso do curso de Letras-Espanhol, em dezembro de 2012, tínhamos 170 alunos matriculados. As disciplinas específicas da área de língua, literatura e estágio supervisionado eram atendidas por 10 docentes, sendo 6 efetivos (60\%) e 4 substitutos (40\%). Dos 6 professores efetivos, 3 são doutores (50\%) e 3 mestres (50\%). Dentre os mestres, 2 são doutorandos. Dentre os substitutos, 2 são graduados, 1 é especialista e 1 é mestre.

\subsection{Participantes da pesquisa}

No que concerne aos participantes, podemos dividir nossa pesquisa em dois momentos. O primeiro compreende uma coleta de dados realizada em dezembro de 2012 com os alunos do curso de Letras-Espanhol do Campus VI da UEPB. Portanto, nesta ocasião, eram participantes os 170 alunos matriculados no curso.

No segundo momento, que ocorreu no semestre letivo de 2013.2 (outubro de 2013 a março de 2014) ${ }^{7}$, promovemos diversos momentos de reflexão mediada pelo cinema, a saber: ao longo dos componentes curriculares "Estágio Supervisionado IV" (90h), "Linguística Aplicada à língua espanhola" (60h) e do curso de extensão "O cinema como representação do outro no processo de ensino-aprendizagem de línguas (30h)”. Com a proposta de trabalharmos com um grupo focal, tivemos três alunos participantes da pesquisa, o critério para seleção dos participantes foi que eles tivessem frequentado com assiduidade as três atividades (componentes curriculares e curso de extensão) oferecidas ao longo do semestre.

Optamos por uma quantidade pequena de participantes por conta da complexidade da investigação. Neste sentido, em uma pesquisa qualitativa não é o número de participantes que

\footnotetext{
${ }^{7}$ Por conta de uma greve ocorrida no início de 2013, o segundo semestre letivo não coincidiu com o segundo semestre do ano.
} 
proporciona dados relevantes ao pesquisador, mas o significado e a importância desses dados para a realização da investigação proposta (ROSA \& ARNOLDI, 2009).

\subsection{Panorama do contexto investigado}

Neste item, apresentamos uma análise preliminar do nosso contexto de pesquisa. Neste intuito, contamos com um formulário com perguntas dissertativas e de múltipla escolha que foi aplicado em dezembro de 2012. Apesar da nossa investigação se filiar aos princípios da pesquisa qualitativa de cunho etnográfico, para traçar um panorama do nosso contexto de forma a dar direcionamento às atividades subsequentes, lançamos mão de algumas informações quantitativas.

Neste sentido, sabemos que a pesquisa quantitativa tem seus procedimentos baseados na coleta de dados de uma amostra, que é um subconjunto da população investigada, pois, em geral, é inviável pesquisar toda a população envolvida no objeto de estudo, já que, no caso, seria um censo. A utilização do procedimento por amostragem tem por objetivo efetuar generalizações a respeito da população investigada, com bom nível de confiabilidade (TERRIBILI, 2007, p. 59).

$\mathrm{Na}$ ocasião da coleta de dados, entre diurno e noturno, tínhamos 170 alunos matriculados. Deste montante, subtraímos os alunos que terminaram de cumprir as disciplinas, mas faltam entregar e defender a monografia exigida como Trabalho de Conclusão de Curso (TCC) e, por conta disso, continuam matriculados (mas não frequentam as aulas) e aqueles que desistiram durante o semestre, não estão mais frequentando e que, como não formalizaram o trancamento da matrícula, continuam constando como matriculados. Com a subtração desses casos, sobraram 106 alunos, sendo 17 do diurno e 89 do noturno.

Conforme relatamos no item justificativa, no início do texto desta tese, o curso de Letras-Espanhol do Campus VI da UEPB tem um alto índice de desistência (70\% dos alunos que ingressaram de 2006 a 2009 não se formaram), fato que justifica que dos 170 alunos matriculados tínhamos apenas 106 frequentando o curso.

\begin{tabular}{|l|c|c|}
\cline { 2 - 3 } \multicolumn{1}{c|}{} & Frequentes & Porcentagem \\
\hline Diurno & 17 & $16 \%$ \\
\hline Noturno & 89 & $84 \%$ \\
\hline Total & 106 & $100 \%$ \\
\hline
\end{tabular}

Tabela 1: divisão dos alunos frequentes entre os turnos diurno e noturno. 
Desses 106 alunos, 96 participaram da pesquisa preenchendo o questionário. Ou seja, conseguimos abranger $90 \%$ do nosso público, o que nos apresenta uma amostra ${ }^{8}$ significativa de dados. Os questionários foram coletados com participantes de todos os semestres/períodos do curso:

\begin{tabular}{|c|c|}
\hline Período/semestre & $\begin{array}{c}\text { Quantidade de } \\
\text { participantes }\end{array}$ \\
\hline $1 .^{\circ}$ & 12 \\
\hline $2 .^{\circ}$ & 25 \\
\hline $3 .^{\circ}$ & 7 \\
\hline $4 .^{\circ}$ & 11 \\
\hline $5 .^{\circ}$ & 3 \\
\hline $6 .^{\circ}$ & 24 \\
\hline $7 .^{\circ}$ & 4 \\
\hline $8 .^{\circ}$ & 5 \\
\hline $9 .^{\circ 9}$ & 5 \\
\hline & Total: \\
\hline
\end{tabular}

Tabela 2: divisão dos participantes nos semestres/períodos do curso.

A tabulação dos dados coletados nos rendeu um corpus que foi analisado de forma a nos permitir uma visão panorâmica do contexto de pesquisa e traçar direcionamentos para as atividades posteriores, desenvolvidas ao longo do semestre 2013.2, as quais nos possibilitaram a coleta de dados com o grupo focal.

Dentre nossas inquietações, como pesquisador, buscamos, com os questionários aplicados, encontrar respostas ou novas perguntas para as seguintes indagações:

- Qual o perfil sócio-econômico-cultural dos alunos de Letras-Espanhol do Cariri Paraibano?

- Quais são as estratégias e atitudes deles em relação ao aprendizado do E-LE?

- Quais as expectativas desses alunos acerca da profissão "professor de espanhol”?

- Quais as crenças desses professores em formação inicial a respeito do processo de ensinar e aprender línguas estrangeiras?

\footnotetext{
${ }^{8}$ Amostra: "um conjunto de elementos selecionados e extraídos de uma população com objetivo de descobrir alguma característica desta população, e baseando-se no postulado de que as conclusões formuladas sobre a amostra vale também para a população da qual esta foi extraída" (VERA, 1983, p. 49).

${ }^{9} \mathrm{O}$ curso de Letras-Espanhol da UEPB-Campus VI está organizado em 8 períodos (semestres) para o turno diurno e 9 períodos (semestres) para o noturno.
} 
- Quais as crenças do nosso público em relação à variação linguística experimentada pelo espanhol?

- Qual a relação desses alunos com o cinema? Quais as concepções deles sobre as contribuições da sétima arte para o processo de ensino-aprendizagem?

\subsection{Perfil sócio-econômico-cultural dos alunos de Letras-Espanhol do cariri paraibano}

A predominância histórica das mulheres nas licenciaturas se repete em nosso contexto, somando $86 \%$ dos participantes. Quanto à faixa etária do nosso público, 69\% têm entre $18 \mathrm{e}$ 26 anos, a maioria é solteira (75\%), todos são brasileiros e a maior parte $(89 \%)$ reside na região urbana.

A maior parte do nosso público (57\%) não reside na cidade de Monteiro e se desloca diariamente para estudar. Dos nossos alunos, $90 \%$ cursaram todo o ensino fundamental em escolas públicas, $87 \%$ deles cursaram o Ensino Médio comum, sendo 93\% todo em escolas públicas.

Letras-Espanhol é o primeiro curso superior de $91 \%$ deles. $97 \%$ dos alunos nunca viajaram para o exterior, $49 \%$ frequentaram cursinho preparatório para o vestibular. $79 \%$ deles nunca estudaram idiomas em escola de línguas. Dos $21 \%$ que declaram haver estudado em escola de línguas, $13 \%$ estudaram inglês, $7 \%$ espanhol e $1 \%$ francês.

Dos participantes, 91\% declararam não conhecer nenhuma língua estrangeira além do espanhol, os $9 \%$ que relataram conhecer outro idioma citaram o inglês.

Quanto ao grau de escolaridade do pai, apenas 1\% possui curso superior completo. A maioria $(60 \%)$ não concluiu o ensino fundamental. O grau de escolaridade da mãe não apresenta muita diferença, apesar de ter um pouco mais de escolaridade que os pais, apenas $3 \%$ possuem curso superior e a maioria (52\%) também não concluiu o ensino fundamental.

A maior parte do nosso público (57\%) trabalha e estuda, $42 \%$ apenas estudam e apenas 1\% se declarou desempregado. Quanto ao trabalho/ocupação principal, 38\% são empregados assalariados. Em relação à renda familiar bruta, 36\% recebem menos de um salário mínimo (até R $\$ 621,00$ ), 42\% recebem de um a dois salários mínimos (entre R\$ $622,00$ e $\mathrm{R} \$ 1244,00), 6 \%$ de dois a cinco salários mínimos (entre R $\$ 1245,00$ e $\mathrm{R} \$ 3110,00$ ), 3\% de cinco a dez salários mínimos (entre R $\$ 3111,00$ e R \$ 6220,00) e 11\% preferiram não declarar. 


\subsection{Estratégias e atitudes em relação ao aprendizado do E-LE}

As estratégias utilizadas pelos nossos participantes para estudar/aprender espanhol são as mais variadas e se alteram de um aluno para o outro. São recorrentes nas falas deles: anotar tudo que é importante; assistir a: filmes, vídeos, aulas, seriados com legendas e áudio em espanhol; cantar músicas em espanhol vendo a tradução; compreender; comparar com a língua materna; conversar pelo bate-papo; cursos online; escrever; estudar; estudar o dicionário; falar; fazer exercícios; ler (textos, jornais, a respeito dos assuntos citados em classe, em voz alta, histórias da Mafalda); ler regularmente o dicionário; ouvir músicas (bem alto); observar os professores falando; pesquisar (na internet); praticar (no dia a dia, em sala); praticar a gramática; prestar atenção à aula; pronunciar a partir de filmes e músicas; repetir o que ouve; utilizar redes sociais em espanhol; tentar falar; viajar; ver sites especializados, conforme apresentam os excertos ${ }^{10}$ :

[01] Eu releio textos, faço anotações e quando tenho uma dessa com visão cinematográfica, assisto antes e depois de ler a essa para fixar o conteúdo quanto a gramática, eu conjugo mentalmente e depois fixo no papel $\left(6 \mathrm{PE}^{11}\right)$.

[02] Estratégias de leituras, escutando músicas, assistindo filmes em espanhol (6PE).

[03] Procuro entrar em contato com materiais que exponha esta língua além dos materiais expostos em sala de aula (6PE).

[04] Me comunico sempre em espanhol mesmo que as outras pessoas não entendam (6PE).

[05] Praticando com os colegas, lendo livros procurando curiosidades sobre a língua (6PE).

[06] Não digo estratégias, no entanto há vários meios que me aproxima da língua espanhola, músicas, livros, filmes (8PE).

Quando questionados sobre o que acreditam ser mais difícil e mais fácil na aprendizagem do espanhol, a leitura e a semelhança das palavras na língua portuguesa e espanhola são destacadas pelos participantes como os elementos mais fáceis no aprendizado. Os alunos relatam dificuldades de toda ordem: compreender as regras gramaticais, conjugação verbal, os significados das palavras, pronúncia, compreender a língua falada, as variações. A maioria relata dificuldade em compreender a língua em sua modalidade oral. Além da dificuldade em compreender o que ouve, é recorrente a preocupação com a expressão oral.

\footnotetext{
${ }^{10}$ Para facilitar a compreensão do leitor, os excertos apresentados sofreram correção ortográfica, mas sem alteração no conteúdo.

${ }^{11}$ As opiniões dos alunos, recolhidas via formulário de coleta de dados, serão identificadas pela sigla XPE. O X corresponde ao período (semestre) que o aluno estava cursando na ocasião da coleta. $\mathrm{O}$ curso oferecido no diurno dura 8 períodos e, no noturno, 9 períodos.
} 
Conforme apresentaremos com mais detalhes no item "O potencial do cinema como mediador no trabalho com os gêneros orais na aula de E-LE”, do capítulo 4, é consenso entre vários professores e pesquisadores que, das quatro habilidades (ouvir, falar, ler e escrever), a expressão oral é uma das mais difíceis de ser alcançada, constituindo-se, talvez, no maior desafio, tanto para o professor quanto para o estudante. Dentre as quatro habilidades consideradas nesse processo, a produção oral é a que, muitas vezes, mais motiva o professor, e também o aluno, em todo empenho para a coconstrução de mensagens durante a interação verbal em uma nova língua. A dificuldade na hora de expressar-se oralmente também é recorrente no discurso dos nossos participantes conforme ilustram os excertos:

Para mim, o mais difícil é...

[07] A organização das ideias na hora de me expressar (1PE).

[08] De início, a interpretação e depois a adaptação da fala (1PE).

[09] Falar é muito complicado (6PE).

[10] O mais difícil na aprendizagem é falar (6PE).

[11] A interação/a conversação (6PE).

A dificuldade na expressão oral em situações reais de interação justifica-se pela sua complexidade. Revuz (1998) destaca

Objeto de conhecimento intelectual, a língua é também objeto de uma prática. Essa prática é, ela própria, complexa. Prática de expressão, mais ou menos criativa, ela solicita o sujeito, seu modo de relacionar-se com os outros e com o mundo; prática corporal, ela põe em jogo todo o aparelho fonador (...) O sujeito deve pôr a serviço da expressão de seu eu um vaivém que requer muita flexibilidade psíquica entre um trabalho de corpo sobre os ritmos, os sons, as curvas entoacionais, e um trabalho de análise e de memorização das estruturas linguísticas (REVUZ, 1998, p. 216-217).

Apesar de termos participantes que residem em localidades com dificuldade de acesso à internet e alguns deles declararem que não têm o hábito de utilizar computadores, a maioria relatou utilizar a internet para auxiliar no aprendizado da língua. Dentre os sites e ferramentas eles relataram o uso de buscadores para pesquisas, consulta a sites de professores, blogs, livros on-line, ferramentas de tradução, músicas, filmes, vídeos, jornais do Brasil e da Espanha, conjugadores de verbos, vídeo-aulas e cursos on-line (Bussuu ${ }^{12}$, Livemocha ${ }^{13}$ ), site de fonética: los sonidos del español ${ }^{14}$, redes sociais, bate-papos, sites de relacionamento em espanhol $^{15}$, site e tradutor do Instituto Cervantes além da consulta a dicionários on-line.

\footnotetext{
${ }^{12} \mathrm{http}: / /$ www.busuu.com/pt

${ }^{13} \mathrm{http}: / /$ livemocha.com/

${ }_{15}^{14} \mathrm{http}: / /$ www.uiowa.edu/ acadtech/phonetics/spanish/frameset.html

${ }^{15}$ badoo.com/
} 
As respostas de nossos participantes nos indicam que alguns deles são engajados na busca por ampliar os conhecimentos obtidos na universidade, buscando, portanto, complementar a aprendizagem fora do ambiente formal de ensino-aprendizagem.

\subsection{Expectativas em relação à profissão "professor de espanhol"}

Quando questionados a respeito do que esperam da profissão "professor(a) de espanhol", a maioria apresenta expectativas positivas para a profissão (67\%), desses, a maioria (39\%), espera ser um bom professor, crescer profissionalmente e ver bons resultados e apenas $17 \%$ dos participantes declarou não querer ser professor de espanhol, conforme tematizamos na tabela 3 :

\begin{tabular}{|c|c|c|c|}
\hline \multicolumn{3}{|r|}{ Categorias } & Porcentagem \\
\hline \multirow{6}{*}{ 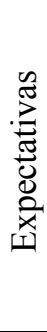 } & \multirow[t]{3}{*}{$\begin{array}{l}\text { Positivas } \\
\quad 67 \%\end{array}$} & $\begin{array}{l}\text { Ser bom professor / crescer profissionalmente / ver bons } \\
\text { resultados }\end{array}$ & $39 \%$ \\
\hline & & $\begin{array}{l}\text { Abrir aos alunos portas para novos mundos / proporcionar aos } \\
\text { alunos novas oportunidades }\end{array}$ & $6 \%$ \\
\hline & & Reconhecimento profissional & $22 \%$ \\
\hline & \multirow{3}{*}{$\begin{array}{l}\text { Negativas } \\
33 \%\end{array}$} & Não quero ser professor(a) & $17 \%$ \\
\hline & & Falta de trabalho & $5 \%$ \\
\hline & & Falta valorização profissional & $11 \%$ \\
\hline
\end{tabular}

Tabela 3: Visões positivas e negativas a respeito da profissão "professor(a) de espanhol".

Encontramos respostas variadas que podem ser divididas em temas que abrigam aspectos positivos com posturas românticas e idealizadas da profissão até visões mais críticas e negativas, apresentando, dentre outros entraves, o não cumprimento da Lei 11.161/2005, que previa a implantação gradativa do espanhol nas escolas de ensino Médio até 2010 e, consequentemente, a escassez de aulas e oportunidades (inclusive concursos) para professores de espanhol na região.

A visão da função do professor como um mediador responsável por compartilhar conhecimentos pode ser vista neste excerto: “[12] Espero exercer um bom papel como professora, compartilhando o conhecimento com os alunos de forma que possamos crescer juntos. Espero também crescer como profissional (1PE)"; a participante tem a visão de que ensinar e aprender forma uma via de mão dupla.

O relato desta participante, que espera crescer junto com os alunos, contrasta com muitas outras falas que não levam em conta a contribuição que os alunos oferecem para o aprendizado e aprimoramento constante do professor: "[13] Passar o que sei para os meus alunos e ver bons resultados (1PE)”, “[14] Espero primeiramente ser uma boa profissional e poder contribuir na aprendizagem de muitos alunos (6PE)", dentre outros. 
Alguns alunos relatam a visão do professor apenas como um transmissor de informações: "[15] Espero obter a maior quantidade de informações possíveis, e transmitir bem os conhecimentos e fazer com que os alunos se apaixonem por esta língua (6PE)", “[16] Que eu possa ter muita bagagem ser uma professora atualizada, fazer alguns intercâmbios para que eu possa repassar muitas informações sobre a língua para os meus alunos (6PE)".

A crença negativa da docência como algo inato e não construído socialmente pode ser observada neste excerto: “[17] Não pretendo ser professora e não nasci com dom (2PE)". Esta crença da docência como um dom vai contra os postulados de Paulo Freire (1991), para este pensador, "ninguém começa a ser educador numa certa terça-feira às quatro horas da tarde. Ninguém nasce educador ou marcado para ser educador. A gente se faz educador, a gente se forma, como educador, permanentemente, na prática e na reflexão sobre a prática" (PAULO FREIRE, 1991, p.32).

É recorrente na fala dos participantes que têm expectativas negativas em relação à profissão a preocupação com as dimensões políticas do ensino de línguas, principalmente as não ações do poder público em relação à Lei n. ${ }^{\circ} 11.161 / 2005$, um gesto claro de política pública em torno da língua, logo, política linguística, que preocupa nossos professores em formação inicial. Vejamos os excertos:

[18] Espero que a lei seja cumprida em todas as escolas e que o profissional como professor seja valorizado (5PE).

[19] Não sei, acho que se a legislação não mudar será complicado (2PE).

[20] Anteriormente fiz um artigo que relata sobre o espanhol na Paraíba e o resultado não foi muito bom, é muito desvalorizado (4PE).

[21] Vai ser um grande desafio, principalmente por causa das leis do Brasil em relação ao ensino de língua espanhola, mas espero que seja gratificante e me complete $(6 \mathrm{PE})$.

[22] Professor de língua estrangeira não é reconhecido como deveria ser por lei (1PE).

Os discursos de nossos participantes também apresentam indagações em relação às condições ainda não especificadas da oferta da lei 11.161/2005, como, por exemplo, a carga horária semanal do componente curricular língua espanhola e da expansão da oferta também para o ensino fundamental. Esta premissa pode ser observada nos excertos:

[23] As escolas que já oferecem a língua espanhola no seu currículo, oferecem apenas uma aula semanal (6PE).

[24] Os atuais professores deverão reivindicar por maior valorização da categoria e da necessidade da aquisição dessa língua nas escolas de rede pública, não só para o ensino médio, mas para o ensino fundamental mais também. (6PE)

[25] Que o governo do estado oferecesse oportunidades nos concursos estaduais para professores de espanhol (6PE) 
A descrença na escola básica como local em que se pode aprender língua estrangeira está presente na fala de um dos nossos participantes. Quando questionado acerca de como se adquire/aprende uma língua estrangeira, ele responde: “[26] por cursinhos, cursos de línguas, letras com habilitação em uma língua estrangeira e até mesmo, raramente, na escola" (2PE destaques nossos).

A implantação da língua espanhola restaura, em alguns de nossos participantes, a crença na possibilidade de se ensinar e aprender línguas estrangeiras na escola, conforme apresentam os excertos:

[27] Espero que essa profissão seja realizada de maneira que coloque o aluno em situações reais da língua e que não seja como a língua inglesa que não proporciona meios para isso. (8PE)

[28] Que não avacalhe com o ensino de espanhol, como o de língua inglesa. (8PE)

Diante do depoimento deste aluno-professor do oitavo período que espera da profissão maneiras de colocar os estudantes em "situações reais da língua", acreditamos que esta tese poderá acrescentar suas contribuições ao apresentar o cinema como um artefato semiótico mediador que congrega, num só suporte, diversos gêneros discursivos pertencentes a diversas esferas sociais de uso da linguagem, capaz de aproximar o estudante de mostras significativas de língua e cultura, produzidas de forma contextualizada.

Pedimos aos participantes que relacionassem os pontos positivos e negativos da profissão "professor de espanhol". As respostas estão tematizadas nas tabelas 4 e 5:

\begin{tabular}{|c|c|}
\hline Pontos positivos da profissão "professor(a) de espanhol” & Porcentagem \\
\hline Contribuir para a formação do aluno/cidadão e mediar a troca de conhecimentos. & $56 \%$ \\
\hline Ser um profissional competente, ter novos conhecimentos e saber outra língua. & $31 \%$ \\
\hline Ter um bom salário, reconhecimento e poder. & $13 \%$ \\
\hline
\end{tabular}

Tabela 4: pontos positivos da profissão "professor de espanhol".

A maior parte dos participantes (56\%) coloca, ao pensar nos aspectos positivos da profissão, o foco no aluno. Já a outra parte (44\%) tem uma visão mais focada em si, voltada para o reconhecimento profissional, conhecimentos adquiridos, salário e poder.

Dentre os pontos negativos, a maioria $(68 \%)$ destaca a má remuneração e, consequentemente a desvalorização profissional, a falta de boas condições de trabalho, bem como o desgaste físico e mental. Os demais participantes $(32 \%)$ colocam o foco nas questões macroestruturais como a falta de políticas públicas para a educação e para a implantação do espanhol como componente curricular, o que acaba - por consequência - resultando na falta de empregos: 


\begin{tabular}{|l|c|}
\hline \multicolumn{1}{|c|}{ Pontos negativos da profissão "professor(a) de espanhol” } & Porcentagem \\
\hline $\begin{array}{l}\text { Má remuneração e, consequentemente a desvalorização profissional, a falta de } \\
\text { boas condições de trabalho, bem como o desgaste físico e mental. }\end{array}$ & $68 \%$ \\
\hline $\begin{array}{l}\text { Falta de políticas públicas para a educação, incluindo a implantação do espanhol, } \\
\text { pois faltam empregos. }\end{array}$ & $32 \%$ \\
\hline
\end{tabular}

Tabela 5: pontos negativos da profissão "professor de espanhol".

Apesar de toda a precariedade e dos desafios da educação básica no Estado da Paraíba, em que até bem pouco tempo atrás era possível - em pleno século XXI- se deparar com alunos sendo transportados em "paus de arara" e até hoje encontrar professores ministrando aulas sem graduação ou fora do seu campo de formação e até diretores de escola sem curso superior ou formação específica em gestão educacional, tivemos participantes (13\%) que relataram como pontos positivos da profissão ter um bom salário, reconhecimento e poder, o que pode ser comprovado nos excertos:

[29] Assalariado e tem folga toda semana (4PE).

[30] Reconhecimento profissional; conhecimento com público diferenciado; remuneração (6PE).

[31] Pouca concorrência, bons salários (6PE).

[32] Conhecimento; poder (6PE).

Entendemos que essas visões se justificam diante da precariedade das relações de trabalho na região. Conforme apresentamos no início deste capítulo, a renda familiar de 36\% dos nossos participantes é menos de um salário mínimo (até $\mathrm{R} \$ 621,00$ ). Temos relatos de diversos alunos que cumprem jornada de $40 \mathrm{~h}$ semanais sem registro em carteira, sem direito a férias, décimo terceiro e os demais benefícios assegurados por lei e que recebem, na maioria das vezes, em torno de meio salário mínimo ao mês. Diante da situação, ainda que com todos os entraves que a profissão docente representa, ela acaba sendo melhor do que o que eles encontram atualmente no mercado.

\subsection{Crenças a respeito do processo de ensinar e aprender línguas estrangeiras}

\section{Definição para língua}

Dentre os conceitos cotidianos espontâneos apresentados pelos nossos participantes para definir "língua", predomina a visão de língua como meio de comunicação (60\%) e como interação (30\%). Encontramos também concepções restritas a um conjunto de palavras/expressões (5\%) e como identidade (5\%). 
Podemos observar que o conceito científico de língua como prática social e mediação simbólica (defendido pelos postulados de Vigotski ${ }^{16}$ ), ou como "atividade sócio-interativa desenvolvida em contextos comunicativos historicamente situados" (MARCUSCHI, 2008, p. 61), predominante atualmente nos meios acadêmicos, não é apresentado pelos nossos participantes.

Houve um participante que reuniu três concepções de língua em uma só resposta: “[33] comunicação, interação, instrumento (8PE)”. Podemos destacar duas definições que apresentam língua como algo curioso: “[34] É o que aprendemos quando nascemos, o que a gente fala ao longo de nossas vidas (2PE)”; “[35] Pra mim, é uma coisa muito curiosa que quanto mais se sabe, mais tenho vontade de descobrir (3PE)".

A visão da instituição como lócus autorizado do saber se confirma na resposta de um participante. Inseguro e sem saber o que escrever para definir língua, ele respondeu: “[36] Até agora não falaram na UEPB (4PE)", ou seja, se ainda não foi visto eu não posso falar sobre este assunto, o que ao mesmo tempo em que demonstra falta de autonomia, mostra o poder do discurso institucional como portador da verdade.

Quando questionados acerca da definição para língua estrangeira, três concepções se destacam: a) 12\% têm a visão de língua estrangeira limitada ao espanhol. Em outras palavras, para eles, "língua estrangeira = espanhol"; b) 44\%: Língua estrangeira como necessidade, oportunidade e/ou passaporte para o mercado de trabalho; c) 44\%: Língua estrangeria como coisa do outro, alheia.

Dentre as respostas, nos chamou a atenção: "[37] Uma nova maneira de conhecer o mundo sem sair do lugar (4PE)", pela consciência da capacidade da LE em intermediar o contato com outros mundos via tecnologias da informação e comunicação, mesmo sem o deslocamento físico. A definição "[39] como uma segunda língua aprendida depois e tendo como referência uma primeira, que foi aprendida no período da infância (5PE)" está em consonância com alguns dos conceitos científicos da área e se aproxima às discussões apresentadas por Revuz (1998), conforme apresentaremos ao longo da tese.

\footnotetext{
${ }^{16}$ Diante das diversas possibilidades, optamos - nesta tese - por grafar Vigotski, seguindo o padrão adotado pelas traduções publicadas no Brasil pela Editora Martins Fontes.
} 


\section{Definição para língua espanhola}

Quando questionados a respeito de uma definição para "Língua espanhola", a maioria (36\%) tem uma visão do espanhol como uma língua interessante, apaixonante e de cultura. As opiniões dos participantes estão sintetizadas na tabela 6 :

\begin{tabular}{|l|c|}
\hline \multicolumn{1}{|c|}{ Categoria } & Porcentagem \\
\hline Língua interessante, apaixonante, de cultura. & $36 \%$ \\
\hline $\begin{array}{l}\text { Língua parecida, mas difícil (o despertar da consciência de que por trás da } \\
\text { transparência existe a opacidade). }\end{array}$ & $18 \%$ \\
\hline Língua muito usada, muito falada. & $14 \%$ \\
\hline Língua parecida, logo, língua fácil. & $10 \%$ \\
\hline Língua de integração. & $8 \%$ \\
\hline Língua com variações/multifacetada. & $4 \%$ \\
\hline Língua espanhola como sistema linguístico. & $4 \%$ \\
\hline Língua espanhola como algo não valorizado nas políticas públicas. & $3 \%$ \\
\hline
\end{tabular}

Tabela 6: definição para língua espanhola.

Chamou-nos a atenção a definição de língua espanhola "[40] como a língua mais viável ao aprendizado dos brasileiros (2PE)", o que nos despertou a curiosidade para saber quais são as crenças e pressupostos que sustentam esta concepção. Será que o nosso participante tem consciência da promoção do espanhol no contexto da integração latinoamericana? Porém, um estudo deste tipo, considerando as crenças como contextuais e sociohistoricamente situadas, não é possível de ser desenvolvido somente com um questionário, esta abordagem foi realizada na segunda etapa da pesquisa, com o grupo focal.

Sabemos que as crenças são construídas socialmente e, neste sentido, é bem provável que a mídia e o discurso de instituições espanholas como o Instituto Cervantes tenham o seu papel na visão da língua espanhola como língua de "bonança, de auge e de prestígio" no território brasileiro (MORENO FERNÁNDEZ, 2005, pp. 18-19). Observemos os excertos:

[41] Uma das línguas mais expandidas em todo universo ao mesmo tempo abrindo as portas do conhecimento mundial (2PE).

[42] O espanhol é uma língua que está em ascensão, os países hispânicos estão se desenvolvendo e é muito importante aprender essa língua para acompanhar esse progresso (2PE).

Esta visão tem sido divulgada em alguns eventos e pela própria mídia de maneira geral, chegando até o imaginário coletivo de alguns de nossos alunos por várias vias, inclusive, pelo discurso de alguns professores. 


\section{O significado de estudar uma língua estrangeira}

As respostas para a pergunta "para você, o que significa estudar uma língua estrangeira?" podem ser tematizadas em dois eixos: 1) língua como passaporte para a ampliação de horizontes e, consequentemente, da visão de mundo $(85 \%)$ e, 2) língua como chave de acesso ao mercado de trabalho (15\%).

Temos consciência da importância de continuarmos lutando para que haja políticas públicas de divulgação, implantação e reconhecimento da importância do ensino do espanhol em nosso território de forma que a Lei n. $^{\circ} 11.161 / 2005$ deixe de ser letra morta e promova a língua viva no contexto da integração latino-americana.

O não cumprimento da lei, que torna a oferta da língua espanhola obrigatória nas escolas de ensino médio e facultativa nas escolas de ensino fundamental, tem como resultado a falta de oportunidades profissionais para professores de espanhol no cariri ocidental paraibano. Este fato, de certa forma, pode inviabilizar o curso de Licenciatura em LetrasEspanhol do campus VI, já que reduz uma faculdade de formação de professores a função de uma escola de línguas. Apesar de oferecer o acesso ao estudo de uma língua estrangeira, o que vai atende ao anseio de $85 \%$ dos participantes da nossa pesquisa que buscam ampliar horizontes e a visão de mundo, não oferece oportunidades no mercado de trabalho.

\section{O que se sabe quando se sabe uma língua estrangeira}

Quando questionados sobre o que sabemos quando temos conhecimento de uma língua estrangeira os participantes nos apresentaram respostas que podem ser divididas em duas categorias:

\begin{tabular}{|l|c|}
\hline \multicolumn{1}{|c|}{ Categoria } & Porcentagem \\
\hline Conhece-se uma nova visão de mundo & $50 \%$ \\
\hline Adquirem-se competências & $50 \%$ \\
\hline
\end{tabular}

Tabela 7: o que se sabe quando se sabe uma língua estrangeira.

Um participante argumentou que quando sabemos uma língua estrangeira ampliamos nossa visão de mundo pela consciência de "[43] que nunca vai se saber tudo (8PE)". Parecenos que este participante tem a crença da qual compartilhamos de que aprender uma língua estrangeira é, em parte, sempre uma utopia, já que por mais que aprendamos e adquiramos competências que nos permitam compreender e ser compreendidos nas mais diversas situações e territórios, sempre teremos a sensação de que falta algo mais a aprender e a conhecer. 


\section{Motivação para estudar o E-LE}

Em relação à motivação para o estudo do E-LE, a maioria relatou o desejo e curiosidade em aprender uma língua estrangeira: “[44] sempre quis aprender outras línguas e espanhol sempre me chamou a atenção (2PE)", “[45] porque sempre gostei do idioma e porque sempre assisti mais novelas mexicanas do que brasileiras. Portanto, o que me motivou foi a cultura dos povos latino-americanos (6PE)". Outros participantes relataram a falta de opção, a oportunidade de trabalho, a vontade de ser professor e o interesse em voltar a estudar, de forma a frequentar uma universidade:

\begin{tabular}{|l|c|}
\hline \multicolumn{1}{|c|}{ Categoria } & Porcentagem \\
\hline Desejo e curiosidade por aprender outra língua & $64 \%$ \\
\hline Falta de opção & $16 \%$ \\
\hline Oportunidade de emprego & $11 \%$ \\
\hline Vontade de ser professor(a) & $6 \%$ \\
\hline Interesse em estudar, frequentar uma universidade & $3 \%$ \\
\hline
\end{tabular}

Tabela 8: a motivação para estudar E-LE.

Dentre os $16 \%$ que relatam a falta de opção, encontramos discursos como apresentam os excertos: "[46] na verdade não foi uma motivação e sim falta de opção (1PE)” e "[47] Falta de opção, mas quando comecei gostei muito (4PE)". A possibilidade de emprego, na maior parte das vezes, está atrelada ao cumprimento da lei 11.161/2005: “[48] a possibilidade de emprego por conta da obrigatoriedade do espanhol nas escolas" (9PE).

Apenas $6 \%$ dos nossos participantes relatam ter como motivação para o estudo do ELE o desejo de ser professor: "[49] desejo lecionar. Pretendo me formar, me especializar e ser ótima profissional (1PE)". Infelizmente, nos deparamos com o quadro de uma instituição voltada para a formação de professores de E-LE que tem uma clientela, na sua maioria, não interessada na docência.

Uma análise do nosso corpus, bem como as conversas informais com os participantes da nossa pesquisa nos permite observar que alguns alunos chegam ao curso de LetrasEspanhol por falta de opção (16\%), mas acabam se envolvendo com a língua estrangeira, uma espécie de paixão, já que $85 \%$ dos nossos participantes buscam, com o estudo de uma língua estrangeira, ampliar horizontes e a visão de mundo e não necessariamente ter mais oportunidades no mercado de trabalho, exercendo, por exemplo, a docência, fala que é comum apenas em $15 \%$ dos participantes.

Esta situação, nestes casos, reduz uma universidade de formação de professores à utilidade de uma escola de línguas (que por fim, pelas especificidades do curso de Letras, não cumpre a expectativa do aluno de uma escola de línguas). Notamos também que o 
desinteresse da maioria em ser professor de espanhol acaba não sendo um problema para a região, já que quase não existem vagas para professores nesta área.

A maioria dos alunos (67\%) relata que a motivação, ou seja, a vontade de estudar e conhecer a língua espanhola aumentou ao longo do curso. Como justificativa, eles argumentam o contato com a língua. Os excertos abaixo mostram-nos isso:

[50] Aumentou em grande proporção, pois a partir do momento em que tive acesso a língua me apaixonei imediatamente e pretendo aprofundar-me cada vez mais (4PE).

[51] Aumentou a vontade de dominar o idioma (4PE).

[52] Aumentou, pois me surpreendi com que aprendi durante o curso. A cultura e as dinâmicas em sala (6PE).

[53] Aumentou, principalmente pela experiência de ter tido contato com falantes nativos, ouvi-los falar, muito lindo (6PE).

[54] Sim só aumentou, o que contribuiu a curiosidade de conhecer os países hispano-falantes as variações linguística e a cultura que é muito interessante (6PE)

[55] Aumentou e muito!!! Em parte pela forma que os professores nos apresentaram o idioma e pelo meu desejo de aprender (6PE).

Dentre os que relataram ter tido a motivação diminuída (33\%), é motivo comum o desprestígio da profissão e o não cumprimento da lei 11.161/2005, que previa a implantação gradativa do espanhol nas escolas de ensino médio até 2010. Vejamos alguns excertos:

[56] Diminuiu, porque o aluno de espanhol é esquecido e quem se formou não tem onde atuar (4PE).

[57] Aumentou, mas ao mesmo tempo diminuiu por falta de interesse do governo em relação ao curso (6PE).

\subsection{Crenças acerca da variação linguística experimentada pelo espanhol}

\section{Identificação com os países de língua espanhola}

Diante da pergunta: "Se você nunca esteve num país que fala espanhol, qual país você gostaria de visitar? Por quê?" na resposta, que era aberta, foram citados noventa e sete vezes nomes de países, organizados na tabela 9 e no gráfico 1 :

\begin{tabular}{|l|c|c|}
\hline \multicolumn{1}{|c|}{ País } & Qtde & \% \\
\hline Argentina & 26 & 27 \\
\hline Bolívia & 1 & 1 \\
\hline Chile & 5 & 5 \\
\hline Colômbia & 1 & 1 \\
\hline Cuba & 1 & 1 \\
\hline Espanha & 40 & 41 \\
\hline México & 18 & 19 \\
\hline Peru & 4 & 4 \\
\hline Venezuela & 1 & 1 \\
\hline Total & 97 & 100 \\
\hline
\end{tabular}

Tabela 9: qual país que fala espanhol você gostaria de visitar? 


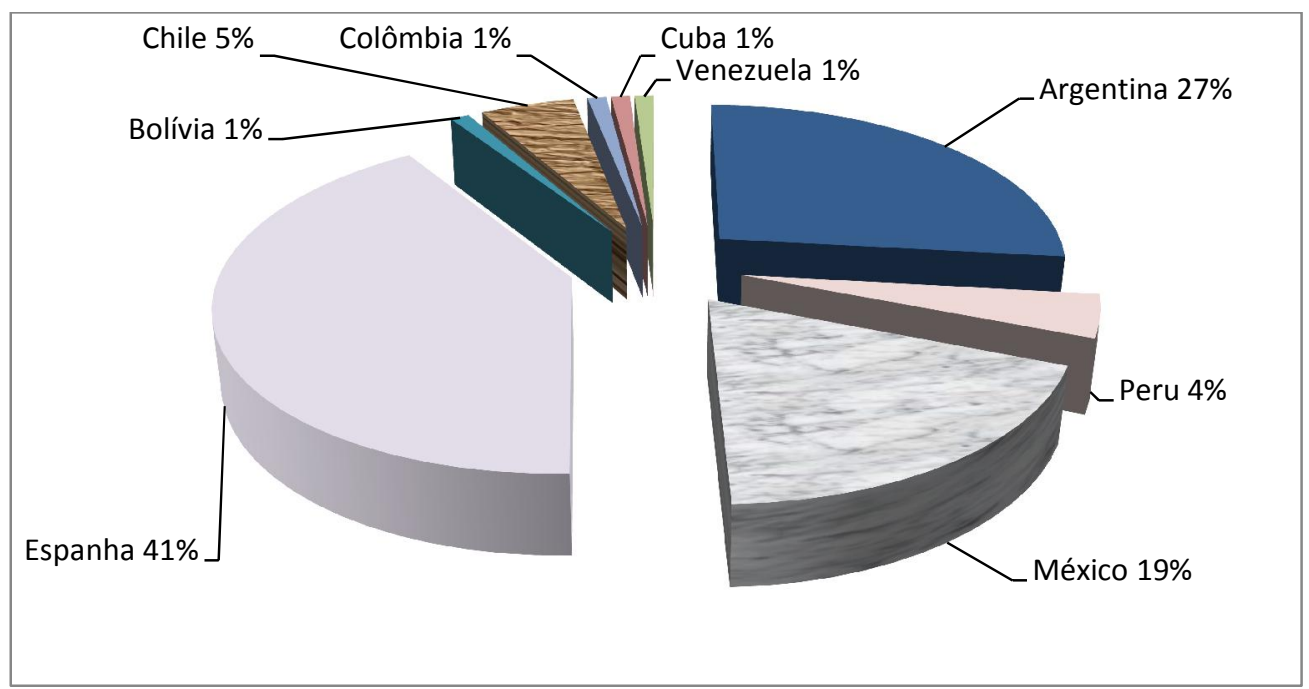

Gráfico 1: qual país que fala espanhol você gostaria de visitar?

A Espanha foi o país mais citado, obtendo 41\%. A Argentina veio em segundo lugar, com $27 \%$ da preferência. México foi o terceiro país mais lembrado, com 19\%, depois Chile, com 5\%; Peru, com 4\%. Bolívia, Colômbia, Cuba e Venezuela foram lembrados, mas alçaram apenas $1 \%$ da preferência.

Tivemos algumas justificativas em relação à escolha de países hispano-americanos, conforme apresentam os excertos: “[58] Argentina porque tem uma variação linguística interessante (6PE)", “[59] México porque é o pais que me motivou a estudar espanhol (6PE)", mas a preferência é pela Espanha, e as crenças da Europa como continente superior e daquele país como "dono da língua" predominam: "[60] Espanha, porque é na Europa (6PE)”, "[61] Espanha, porque é um país europeu (7PE)”, “[62] Espanha, ter contato mais próximo com a língua espanhola (9PE)”, “[63] Espanha. Porque é o berço da língua (6PE)”.

\section{A percepção da variação na língua espanhola}

Quando questionados se acreditam que há variação na língua espanhola, dos que responderam, $87 \%$ acreditam que sim, 13\% declaram que não. Dentre as justificativas para a variação, destacamos os excertos:

[64] Assim como o nosso português varia de região para região, o espanhol também sofre variações (1PE).

[65] Porque tem países que falam o espanhol de maneira diferenciada, como é o caso da letra ch do espanhol (2PE).

[66] Há variações na oralidade. (2PE) 
[67] Como todas as línguas que sempre estão se moldando, existem sim muitas variações. (4PE)

[68] Sim. Acredito que haja, porque mesmo que seja a mesma língua. Há diferentes modos de manifestações e diferentes fatores que contribuem (econômico, social, regional, etc) (6PE)

Uma análise dos depoimentos nos revela que alguns alunos não tem a concepção de variação como inerente a qualquer língua. Eles atribuem um status de língua standard à variedade linguística peninsular e a variação ao Espanhol da América. Os excertos, a seguir, ilustram isso:

[69] Acho que a maioria dos espanhóis preservam-se neutros na língua, por mais que falamos com fluência eles procuram algo, um som, uma variante... para corrigir/comentar (6PE).

[70] Entre falar como um Espanhol ou Latinoamericano, prefiro falar como um latino-americano pois assim meus erros não serão tão facilmente apontados (6PE).

\section{Percepção acerca do espanhol utilizado no início de um curso}

Quando questionados "você acha mais importante que um curso seja iniciado com o espanhol da Espanha ou com o Espanhol da América?", dos que responderam, 71\% preferem o espanhol da Espanha e somente 29\%, o espanhol da América. Dentre as poucas justificativas para que o curso fosse iniciado pelo Espanhol da América temos o excerto: "[71] O Brasil participa do Mercosul (A Espanha não é participante, pois é Europa) (1PE)”, esse participante foi o único que deu vestígios dos argumentos que apresentamos no capítulo 3 desta tese, isto é, de que para a integração latino-americana o linguístico exerce um papel fundamental.

Dentre as justificativas para que um curso fosse iniciado pelo espanhol da Espanha, selecionamos alguns excertos

É mais importante que um curso seja iniciado com o espanhol da Espanha por que...

[72] Pois falar na língua nativa é bem mais interessante (1PE).

[73] Por ser de melhor compreensão (1PE).

[74] Acho que poderíamos, por curiosidade, ter mais vontade de seguir, com um professor Espanhol (1PE).

[75] Porque gosto dos costumes da Espanha (2PE).

[76] É melhor para aprender (2PE).

[77] O país é mais tradicional (2PE).

[78] Pois é um país com forte influência na língua espanhola (2PE).

[79] Teríamos uma proximidade maior com o idioma, digamos que oficial (2PE). 
[80] Acho que devemos conhecer primeiro a origem [espanhol da Espanha] e depois as variações [espanhol da América] (2PE).

[81] Para aprender de forma mais amplas a cultura bruta da Espanha sem a influência de outros povos (6PE).

[82] Se é espanhol, é mais aconselhável que seja da Espanha (7PE).

[83] [Um ponto negativo do curso] é ter professores sem ser da Espanha (2PE).

A clássica crença de que ser nativo do idioma (native-speaker-ness) é suficiente para ser professor daquela língua também está presente em nossos achados de pesquisa. Os excertos 74 e 83 trazem implícitos duas crenças: 1) de que o bom professor de língua estrangeira tem que ser nativo; 2) No caso do Espanhol, não basta ser nativo, tem que ser espanhol (natural da Espanha).

Sabemos que, historicamente, o que se tem entendido como o nível desejável de competência para que o professor possa ensinar é o de um falante nativo. Porém, esta concepção tem sido discutida ultimamente. Dentre os questionamentos, destaca-se: que falante nativo seria esse? A variação é inerente a qualquer língua e mesmo no caso do espanhol da Espanha, seria melhor o nativo usuário de qual variante? Temos também que levar em conta que o indivíduo pode ser nativo e ter um nível baixo de competência linguística na sua própria língua. Diante disso, fica difícil estabelecer um modelo de espanhol nativo, como se buscava anteriormente. Outra questão importante é que somente o conhecimento da língua não basta para que alguém possa ser professor de línguas; sabemos que outros saberes são também necessários.

Tivemos, em nossa coleta de dados, situações que mostram que quando o participante está seguro do seu discurso e utilizamos questionários semiabertos, ele pode transgredir as limitações impostas pelo formulário. No caso da pergunta:

Você acha mais importante que um curso seja iniciado com:

( ) Espanhol da Espanha

( ) Espanhol da América

Justifique:

Alguns participantes apresentaram comportamentos interessantes. Houve um aluno do terceiro semestre do curso que marcou Espanhol da Espanha e justificou: "[84] Acho que é importante se aperfeiçoar nos dois (3PE)".

Outro participante, também do terceiro semestre, marcou Espanhol da Espanha e justificou: "[85] A opção foi marcada por falta de opção porque por mim tanto faz. O que importa é aprender" (3PE), ao mesmo tempo em que o aprendiz se coloca como sujeito de seu 
discurso ao transgredir ao modelo do questionário, percebemos a falta de posicionamento sócio-político-ideológico, já que para ele não importa qual a ênfase que seja dada ao curso de línguas.

Houve o caso de participantes que não marcaram nem da Espanha, nem da América, ou marcaram ambos. Dentre as justificativas, apresentamos os excertos:

[86] Não acho que um espanhol ou outro seja melhor, algumas pessoas preferem o Espanhol da Espanha por ser considerado o 'padrão', embora minha variante seja uma, não desvaloriza a outra (6PE).

[87] Todas as variantes são importantes para o processo de ensino aprendizagem de língua espanhola (6PE).

[88] Ambos devem ser apresentados, pois o espanhol é uma língua só, que no entanto tem variações que não devem ser esquecidas. (6PE).

[89] Acredito que nenhum dos dois, creio deve-se iniciar apenas com "espanhol", mas mostrando que existem variações em determinados lugares (6PE).

Um participante do oitavo semestre do curso marcou as duas opções e argumentou: "[90] O aluno tem que ser conscientizado sobre tais variações, portanto, não teria que haver essa dicotomia entre os dois (8PE)". Notamos que este conceito relatado pelo participante se aproxima muito do conceito científico apresentado pela literatura da área. Rona (1964) já argumentava que a "homogeneidade" do espanhol americano é um mito que pode ser atribuído "ao fato de ter-se começado a falar e escrever a respeito do espanhol americano antes de se conhecer o espanhol americano ${ }^{17 ”}$ (p.125). Neste sentido, sabemos que a língua espanhola é o idioma comum a vinte e um países (se considerarmos os Estados Unidos), e que -como língua natural- possui diferenças - léxicas, fonéticas e, num menor grau, morfossintáticas- em situações de uso em uma ou outra região. Lope Blanch (1989) já destacava que as diferenças que ocorrem entre a língua falada nestes países não nos permite estabelecer duas grandes modalidades bem contrastadas, espanhola e americana e, além disso, existe maior afinidade entre algumas modalidades americanas e espanholas que entre certas modalidades hispano-americanas entre si.

Observamos que, de uma forma geral, as imagens que nossos alunos têm associadas ao espanhol da Espanha e o espanhol da América estão atreladas à velha dicotomia "espanhol da Espanha (prestígio)” x "Espanhol da América (desprestígio)". Alguns trabalhos ressaltam que esta visão tem sido comum entre professores de espanhol. Não sabemos de onde ecoa este discurso que ressoa em nossos alunos (professores em formação). Um desafio para pesquisas

\footnotetext{
${ }^{17}$ No original: "al hecho de que se empezara a hablar y escribir del español americano antes de conocerse el español americano".
} 
futuras seria buscar compreender as crenças dos professores da instituição e as possíveis relações com as crenças dos alunos.

\section{Identificação com os falantes da língua}

No caso da pergunta "Você se sente ou se sentiria melhor falando como um...? a) Espanhol; b) Latino-americano", dos que responderam, a maioria (59\%) se sentiria melhor falando como um espanhol. Dentre os comentários, que eram opcionais, apresentamos alguns dos excertos que justificam a identificação com os espanhóis:

[91] Pois acho que aprenderia mais (1PE).

[92] Até o momento só tive oportunidade de ouvir pessoas falando espanhol (1PE).

[93] Espanhol. Acho mais bonito (3PE).

[94] Porque me encanta o espanhol da Espanha (6PE).

[95] Porque estou aprendendo espanhol (6PE).

[96] Espanhol. O espanhol fala com mais eloquência, as variações são mais conhecidas (7PE).

Dentre os comentários, no caso da identificação com um latino-americano, destacamos os excertos:

[97] Por causa das variações (1PE).

[98] Pela experiência com os latino-americanos (morei seis meses no Uruguay) (1PE).

[99] Porque não estaria abandonando a minha origem (2PE).

[100] Não almejo falar como um espanhol, simplesmente porque não nasci na Espanha (4PE).

[101] Porque me sentiria mais segura (4PE).

[102] Latino-americano porque me sentiria mais familiarizado (6PE)

[103] Latino-americano porque é aquele que está mais próximo do nosso país (6PE).

[104] Acho que a maioria dos espanhóis preservam-se neutro na língua, por mais que falamos com fluência eles procuram algo, um som, uma variante... para comentar (6PE).

[105] Porque nunca vai falar igual a um espanhol nativo (6PE).

[106] Por me aproximar mais com a minha região, ou seja, país de origem (6PE).

[107] Porque são os que estão mais próximos do Brasil, e possivelmente vamos ter mais contato (6PE).

[108] Pois assim meus erros não serão tão facilmente apontados (6PE).

[109] Como latino-americanos não perderíamos nossa identidade (8PE).

A tendência ao perfil intercultural desejado na contemporaneidade e a visão do professor como mediador cultural pode ser observado nas excertos "[110] Gostaria dos dois [falar como um espanhol e como um latino-americano], não tenho preferência, acho que 
dependeria das situações (3PE)" e "[111] Acredito que não há preferência porque temos que nos prepararmos para falar e compreender todas as variações (6PE)".

Houve um participante que relatou não ter interesse em falar nem como espanhol nem como latino-americano, mas sim "[112] uma mistura de todas as variantes (8PE)". Este discurso nos remete às reflexões de Celada e Rodrigues (2005) que relataremos no capítulo 3 desta tese: independente da variante de espanhol adotada em nosso território, temos de encarar o fato de que aqui se desenvolverá um "Espanhol brasileiro", fruto das novas formas de dizer que resultam da maneira como um brasileiro explora sua posição específica de estrangeiro e no espanhol se inscreve. Neste mesmo sentido, as OCEM-Espanhol (MEC, 2006) ressaltam, ao discutir qual variante o professor brasileiro de espanhol deve utilizar, que por ter o espanhol como língua estrangeira o professor acaba, inevitavelmente, mesclando fragmentos de variedades diferentes e essa seria "a sua forma 'natural' de se expressar, a que conhece melhor e à qual se sente mais vinculado. Portanto, essa deve ser a modalidade fundamental de expressar-se, em aula ou fora dela" (p. 136). Ressaltamos que estas reflexões são relevantes para pensarmos a construção da identidade linguística do professor de E-LE no Brasil, e que estas visões não podem ser interpretadas como estímulos à prática do portunhol e sim um convite ao aprimoramento contínuo dos estágios de interlíngua ${ }^{18}$ do professor via formação inicial e continuada.

O discurso de um participante, além da alta carga de preconceito linguístico, nos mostra a crença da língua espanhola como uma herança genética. Ele argumenta que quando estiver falando espanhol com fluência gostaria de falar como um espanhol, pois "[113] os espanhóis sempre falarão melhor por serem nativos e terem a língua no sangue mesmo (2PE)".

\subsection{Nossos alunos e o cinema}

Monteiro e as cidades da região (em que estão distribuídos 57\% dos nossos participantes) fazem parte do ranking composto por $90 \%$ das cidades brasileiras que não possuem sala de cinema. Pelo que pudemos apurar, a sala de cinema mais próxima fica há pouco mais de $100 \mathrm{~km}$. Dessa forma, dos que responderam à pergunta "com que frequência você vai ao cinema?", $60 \%$ nunca foram ao cinema, 18\% têm o hábito de ir menos de uma

\footnotetext{
18 O caminho traçado da língua materna à língua alvo foi definido por Selinker (1972) como interlíngua, vocábulo utilizado para designar o sistema linguístico não-nativo usado pelo indivíduo que aprende outra língua. Uma conceituação contemporânea seria a proposta por Cruz (2004, p. 27): competência linguístico-comunicativa que o aprendiz de língua estrangeira manifesta na sua produção, marcada pela variabilidade em um trajeto com avanços, regressões, instabilidade e possíveis fossilizações até sua etapa final.
} 
vez por ano, $16 \%$ vão ao menos uma vez por ano e somente $6 \%$ frequentam uma sala de cinema ao menos uma vez por mês.

Quando questionados a respeito da frequência com que assistem a filmes (no computador, em DVD, ou em outros suportes), sozinhos ou com amigos, fora de ambientes comerciais, $42 \%$ declararam assistir raramente, $34 \%$ toda semana e $20 \%$ uma vez por mês.

Dos 54\% que tem o costume de assistir a filmes (toda semana ou ao menos uma vez por mês), a maioria (51\%) declarou que não tem o hábito de fazer download da internet e quando vão comprar filmes piratas ou alugar (prática que não é comum na região), não tem o hábito de procurar por produções em língua espanhola.

\subsection{Considerações}

Sabemos que a tarefa de formar professores de língua estrangeira nos coloca diante de um processo em permanente construção. Vemo-nos no desafio de, ao longo da trajetória acadêmica do aluno-professor e, se possível, em cursos de extensão, programas de pósgraduação e de formação continuada, promover atividades que permitam transformar os conhecimentos cotidianos (em relação à língua espanhola e da linguagem em geral, além do complexo processo de ensinar e aprender língua), a partir da reflexão mediada por atividades concretas, em contextos sociais, à luz de conceitos científicos.

Neste sentido, este capítulo nos permitiu apresentar um panorama das crenças (que compõem os conceitos cotidianos) dos participantes acerca de questões importantes que tem implicações diretas em sua formação para o campo do ensino-aprendizagem do E-LE. Na maior parte dos casos, para se estabelecerem como profissionais competentes e reflexivos, faz-se necessário partir dos conhecimentos empíricos e experienciais e ir além, na busca por práticas teoricamente embasadas que lhes permitam explicar como e porque ensinam da maneira como ensinam e, consequentemente obtém os resultados que obtém.

Já é consenso entre os estudiosos que o mundo é heterogêneo por natureza. Este pensamento, transposto para o universo educativo nos permite observar que nosso contexto pesquisado é permeado por diversas e diferentes crenças. A partir da perspectiva sociocultural, acreditamos ser a massa heterogênea a liga social necessária para que uns acelerem o desenvolvimento de outros. Nesse contexto, o professor - enquanto mediador mais capaz - pode lançar mão de atividades em equipes heterogêneas (compostas por membros com diferentes crenças) para que um auxilie no desenvolvimento e no constante processo de (re)construção de crenças do outro. 
Ressaltamos que, neste capítulo, não esgotamos de forma exaustiva a análise de todo o material coletado. Buscamos destacar os itens mais relevantes para traçarmos o perfil do nosso público-alvo de forma a obter subsídios para direcionarmos os planejamentos dos componentes curriculares e do curso de extensão que foram oferecidos em 2013.2, nos quais coletamos os dados com o grupo focal.

Os questionários aplicados nesta fase preliminar da pesquisa tiveram sua relevância por possibilitar desvendar algumas das crenças do grupo investigado e traçar direcionamentos para ações subsequentes, mas não nos permitem esclarecê-las de forma contextualizada e nem observar até que ponto elas podem, ou não ser alteradas a partir das reflexões mediadas pelo cinema. Esta constatação foi realizada posteriormente, com o grupo focal.

Silva (2005b) argumenta que os estudos das crenças podem ser "o ponto de partida para as teorizações, ou seja, uma reserva potencial para os pressupostos do ensino de línguas, intimamente interligada com a nossa prática pedagógica e com a formação de professores de línguas" (p. 160). Neste sentido, a partir dos nossos principais achados de pesquisa, dentre eles: a preferência pela Espanha como país a ser conhecido enquanto estudante de espanhol e, consequentemente, a identificação exacerbada com a língua e cultura faladas na Espanha, bem como a falta da cultura de apreciação do audiovisual e a invisibilidade da América Latina e a não consciência da integração regional, direcionamos todas as discussões teóricas e as ações subsequentes ao longo da pesquisa. Dessa forma, o nosso próximo capítulo está dedicado a compreender as crenças como componente da cognição de professores numa perspectiva sociocultural. 
CAPÍTULO 2

CRENÇAS COMO COMPONENTES DA COGNIÇÃO DE PROFESSORES DE ESPANHOL - LÍNGUA ESTRANGEIRA (E-LE) EM FORMAÇÃO INICIAL NUMA PERSPECTIVA SOCIOCULTUAL 
Contrário ao antigo provérbio "ver para crer", é mais provável que seja "crer é ver". Quando as pessoas acreditam que algo é verdadeiro, elas percebem informações que reforçam aquela crença. As crenças alteram as expectativas. As pessoas acreditam no que esperam perceber (YERO, 2002 apud BARCELOS, 2007, p. 111).

Talvez a causa mais importante do sucesso ou fracasso educacional de uma pessoa tem a ver com a questão do que ela acredita sobre si mesma (Arthur Combs apud PAJARES, 1992, p. 307).

Las creencias constituyen la base de nuestra vida, el terreno sobre que acontece. Porque ellas nos ponen delante lo que para nosotros es la realidad misma. Toda nuestra conducta, incluso la intelectual, depende de cuál sea el sistema de nuestras creencias auténticas. En ellas "vivimos, nos movemos y somos" (José Ortega y Gasset, Ideas y creencias - Obras Completas, vol. V, Alianza Editorial). 
Concordamos com alguns pesquisadores como Almeida Filho (1993) e Barcelos (1999), por exemplo, que afirmam que a cultura de aprender e ensinar uma língua estrangeira baseia-se em teorias implícitas que são compostas por fatores como crenças, motivações, memórias, intuições e imagens, dentre outros.

As concepções dos agentes envolvidos na operação global do ensino de línguas (ALMEIDA FILHO, 1993, p. 22) exercem profunda influência em todo o processo, já que cada indivíduo, permeado por seu contexto sócio-histórico-discursivo tem suas crenças que embasam as atitudes que norteiam seu comportamento em face do complexo processo de ensino-aprendizagem de línguas.

Parafraseando Barcelos (2001), podemos afirmar que as crenças, em termos gerais, podem ser definidas como opiniões e ideias que alunos, professores e demais envolvidos têm a respeito dos processos de ensinar e aprender línguas. Dessa maneira, as crenças de um professor, por exemplo, influenciam suas tomadas de decisão em todos os aspectos, seja na seleção de conteúdos, na elaboração de atividades ou na forma como conduz suas aulas e nas produções e comportamentos que espera do aprendiz.

Neste capítulo, dentre as diferentes lentes e possíveis caminhos para a compreensão daquilo que nesta tese trataremos como crenças, adotaremos a perspectiva sociocultural e interpretaremos as crenças como um elemento da cognição de professores. Neste intento, contaremos, dentre outros teóricos, com Barcelos (2001, 2006, 2007), Borg (2006), Johnson (2009), Pajares (1992, 1996), Vieira-Abrahão (2010, 2012) e Vigotski (2001, 2007, 2009).

\subsection{Uma perspectiva sociocultural da formação de professores de línguas}

Vieira-Abrahão (2012) apresenta que o ensino e a pesquisa relacionados ao campo da formação de professores de línguas vêm passando por inúmeras mudanças ao longo do tempo. Para a pesquisadora, "essas transformações não têm acontecido de forma isolada, mas vinculadas às diferentes maneiras de se conceber a realidade e o conhecimento, ou seja, às diferentes perspectivas epistemológicas" (p. 458).

Nesse sentido, a perspectiva epistemológica positivista, também conhecida como o método científico, é vista como superada. Nela, estava enraizada a crença de que a realidade existe para além do conhecedor e pode ser capturada por meio de um processo cuidadoso e sistemático de coleta de dados, análise e interpretação. 
Nesta visão, o conhecimento era considerado objetivo e identificável, e representava verdades generalizáveis. Era como se o conhecimento estivesse fora do indivíduo e pudesse ser identificado e analisado por meio do uso de métodos científicos.

Nesta perspectiva, na formação de professores de línguas, havia a supremacia do treinamento para o uso de práticas específicas, consideradas como ideais, que eram antecedidas pela exposição e "transmissão" de conhecimentos gerados em investigações na área de Linguística Aplicada e em Aquisição de Línguas. Resultado de uma perspectiva positivista, surgiu a teoria behaviorista de aprendizagem, que a vê como formação de hábitos, como consequência de estímulo e reforço. Formar professor neste modelo era, portanto, condicioná-lo por meio de treinamento (VIEIRA-ABRAHÃO, 2012).

Pesquisadores argumentam que a maior falha do behaviorismo consistiu em não considerar a construção de sentidos que os envolvidos no processo de ensino-aprendizagem atribuem aos seus mundos e os processos cognitivos/mentais solicitados na tarefa de aprender, elemento primordial no processo.

As críticas feitas ao positivismo consideram que "a complexidade das salas de aula não podem ser captadas por estudos experimentais e que a realidade está tanto no exterior como nas mentes dos professores, o que não era contemplado com as tentativas de isolar variáveis e buscar generalizações" (VIEIRA-ABRAHÃO, 2012, p. 458).

Como reação à pesquisa positivista, temos a pesquisa interpretativista, baseada no pressuposto de que o conhecimento é socialmente construído e emerge das práticas sociais nas quais as pessoas estão envolvidas. Portanto, a realidade social é entendida como sendo coconstruída por pessoas, e existe, em grande parte, dentro da mente das pessoas. Visto a partir desta concepção, o objetivo da pesquisa interpretativa é ampliar a compreensão de como as pessoas participam e constituem a realidade social. Visão que se aplica perfeitamente a esta tese, haja vista que nosso escopo abarca compreender as crenças que permeiam a constituição do "eu professor" de alunos de Letras, ou seja, professores de espanhol-língua estrangeira em formação inicial.

Nesta concepção, o grande desafio na formação de professores é investigar como eles participam na constituição de seus mundos profissionais e, considerando suas experiências prévias, a interpretação das atividades por eles desenvolvidas e os contextos em que atuam; 
bem como considerar o que os "professores sabem, honrar esse conhecimento e ajudá-los a esclarecer e resolver os dilemas que enfrentam ${ }^{19 "}$ (JOHNSON, 2009, p. 9).

Com Borg (2006) e Johnson (2009) abordamos as crenças a partir de uma perspectiva sociocultural. Nesta linha, compreendemos este constructo como um componente da cognição de professores, dentre vários outros, em constantes reformulações.

Johnson (2009) nos apresenta reflexões acerca da formação do professor de línguas estrangeiras numa perspectiva sociocultural, visão muito oportuna e que vem ao encontro do escopo desta tese. Neste intuito, a autora, a partir de uma visão global a respeito dos fundamentos epistemológicos desta perspectiva, argumenta que a adoção desta visão para a compreensão do processo de ensinar e aprender línguas muda a forma como compreendemos a maneira pela qual os professores aprendem a ensinar, pensam e ensinam línguas. Além disso, a perspectiva sociocultural nos propicia um olhar para a complexidade dos elementos como estruturas sociais, culturais e macroestruturas históricas que permeiam o desenvolvimento do professor de línguas.

Compartilhamos, nesta investigação, da perspectiva sociocultural da formação de professores por acreditarmos que orienta a aprendizagem humana de forma a compreender e apoiar o desenvolvimento do professor de línguas e, no caso do nosso estudo, da formação inicial do professor de espanhol-língua estrangeira. A autora compreende a aprendizagem docente como um processo dialógico de construção conjunta de conhecimentos que é situado e emerge da participação em práticas e contextos socioculturais.

Nosso intento, neste sentido, é buscar, a partir de Johnson (2009), uma compreensão global dos fundamentos epistemológicos da perspectiva sociocultural do aprendizado humano, focando nas contribuições desta visão para o campo da formação inicial de professores de línguas. O quadro 6 apresenta, de forma sintetizada, os principais postulados da perspectiva sociocultural que orientam esta pesquisa:

\footnotetext{
${ }^{19}$ No original: "what teachers know, honors what they know, and helps to clarify and resolve the dilemmas they face".
} 


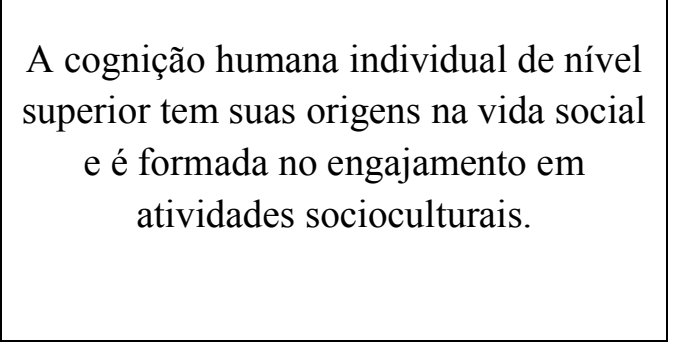

A aprendizagem não é a apropriação direta de conhecimentos de fora para dentro, mas resultado da interação entre o indivíduo e as atividades socialmente mediadas.
O "desenvolvimento só pode ser compreendido à luz das práticas culturais e as circunstâncias de suas comunidades que estão sempre também mudando"

(ROGOFF, 2003, pp.3-4).

\section{SEGUNDO A PERSPECTIVA SOCIOCULTURAL...}

É possível explicar a relação entre o funcionamento mental humano, por um lado, e as situações culturais, institucionais e históricas em que ocorre este funcionamento, por outro.
Como um indivíduo aprende alguma coisa, o que é aprendido, e como isso é usado dependerá da soma de suas experiências anteriores, dos contextos socioculturais em que a aprendizagem ocorre, do que o indivíduo deseja, suas necessidades e/ou as expectativas com esse conhecimento.
As atividades sociais e a língua usada para regular essas atividades são estruturadas e ganham significados em contextos histórico e culturalmente situados.

Quadro 6: Principais postulados da perspectiva sociocultural que orienta esta pesquisa. Fonte: Johnson (2009). Adaptação, compilação e tradução nossa. 
Originalmente, a perspectiva sociocultural tem suas bases nos postulados de Vigotski (2001, 2007, 2009) e seus seguidores Leontiev (1981) e Luria (1982); bem como em diversos pesquisadores contemporâneos que se tem dedicado a estudar e ampliar suas proposições. Dentre eles, é possível citar Cole (1996), John-Steiner (1997), Kozulin (1998), Lantolf (2000, 2006), Wells (1999) e Wertsch (1991).

Conforme expusemos no quadro 6, esta perspectiva assume a cognição humana como emergente do engajamento em atividades sociais, e são as relações sociais e os materiais culturalmente construídos, signos e símbolos, chamados de artefatos semióticos, que medeiam as relações que criam formas exclusivamente humanas de pensamento em nível superior.

Dessa forma, compartilhamos de uma visão que enfatiza o papel da ação no processo de desenvolvimento humano e reconhece que a aprendizagem não é a apropriação direta de conhecimentos de fora para dentro, mas resultado da interação entre o indivíduo e as atividades socialmente mediadas.

Assim, o desenvolvimento cognitivo não é simplesmente uma questão de aculturação ou mesmo apropriação de recursos existentes e práticas socioculturais, mas a reconstrução e transformação desses recursos e práticas de forma que atendam tanto às necessidades individuais quanto sociais/coletivas.

Como um indivíduo aprende alguma coisa, o que é aprendido, e como isso é usado dependerá da soma de suas experiências anteriores, dos contextos socioculturais em que a aprendizagem ocorre, do que o indivíduo deseja, suas necessidades e/ou as expectativas com esse conhecimento.

A perspectiva sociocultural que compartilhamos nesta tese representa uma teoria da mente na qual a linguagem exerce um papel central, pois a mente humana é mediada por artefatos simbólicos socialmente construídos, incluindo, principalmente, a linguaguem. Assim,

É por meio da linguagem, tanto falada quanto escrita, que gerações sucessivas se beneficiam da experiência daqueles que já se foram, e é através dela que cada nova geração compartilha e define suas próprias experiências. $\mathrm{Na}$ perspectiva sociocultural, a linguagem do indivíduo se desenvolve a partir da sua relação com as funções que ela desempenha nas atividades socioculturais das quais os indivíduos participam. Assim, embora a perspectiva sociocultural represente uma teoria da mente, em vez de uma teoria da linguagem, ela se concilia com teorias da linguagem que enfatizam 
a natureza primordialmente social da língua e que a conceituam como prática $\operatorname{social}^{20}$ (JOHNSON, 2009, p. 44).

Neste momento, é importante esclarecermos que para Vigotski, pensamento e linguagem não nascem juntos e diretamente interligados. Dito de outra maneira, "o pensamento e a linguagem têm origens diferentes e desenvolvem-se segundo trajetórias diferentes e independentes, antes que ocorra a estreita ligação entre esses dois fenômenos" (OLIVEIRA, 1993, p. 43). A respeito disto, o pensador argumenta:

A descoberta mais importante sobre o desenvolvimento do pensamento e da fala na criança é a de que, num certo momento, mais ou menos aos dois anos de idade, as curvas da evolução do pensamento e da fala, até então separadas, cruzam-se e coincidem para iniciar uma nova forma de comportamento muito característica do homem (VIGOTSKI, 2009, p. 130).

O autor apresenta este momento como sendo crucial, pois nele a fala se torna intelectual e o pensamento verbalizado, caracterizado por dois sintomas objetivos indiscutíveis e intimamente interligados: “i) a criança que sofreu essa mudança começa a ampliar ativamente o seu vocabulário, perguntando sobre cada coisa nova (como isso se chama?); ii) dá-se a consequente ampliação de seu vocabulário, que ocorre de forma extremamente rápida e a saltos" (VIGOTSKI, 2009, p. 131).

A compreensão da evolução da relação pensamento e linguagem até tornarem-se ligados e se influenciarem mutuamente é de extrema relevância, porém, não nos deteremos a analisar este trajeto detalhadamente, o que resultaria em um discurso extenso que fugiria do escopo desta tese.

Pelo fato de termos adultos como participantes, diante da limitação de tempo e espaço, optamos por não nos determos detalhadamente nesta questão. Vigotski apresenta que o significado da palavra é, ao mesmo tempo, fenômeno discursivo e intelectual. Para o pensador,

O significado da palavra só é um fenômeno de pensamento na medida em que o pensamento está relacionado à palavra e nela materializado, e viceversa: é um fenômeno de discurso apenas na medida em que o discurso está

\footnotetext{
${ }^{20}$ No original: "It is through language, both spoken and written, that successive generations benefit from the experience of those who have gone before and it is language that each new generation uses to share and define its owns experiences. From a sociocultural perspective, the language of the individual develops in relation to tis functions within the sociocultural activity in which the individual participates. So, while a sociocultural perspective represents a theory of mind rather than a theory of language, it does align well with theories of language that emphasize the fundamentally social nature of language and conceptualize language as social practice".
} 
vinculado ao pensamento e focalizado por sua luz. É um fenômeno do pensamento discursivo ou da palavra consciente, é a unidade da palavra com o pensamento (VIGOTSKI, 2009, p. 398 - grifo do autor).

Dessa maneira, é por conta dessa relação entre pensamento e linguagem que o discurso dos participantes de nossa pesquisa pode nos permitir analisar suas crenças. Neste intuito, temos que considerar que a expressão do pensamento é mediada pela linguagem, tanto em sua modalidade oral quanto escrita.

A linguagem não é um simples reflexo especular da estrutura do pensamento, razão por que não se pode esperar que o pensamento seja uma veste pronta. A linguagem não serve como expressão de um pensamento pronto. Ao transformar-se em linguagem, o pensamento se reestrutura e se modifica. $O$ pensamento não se expressa, mas se realiza na palavra (VIGOTSKI, 2009, p. 412).

Do ponto de vista sociocultural, a linguagem é um meio vital pelo qual os seres humanos representam o pensamento. Vigotski (2007) descreve a linguagem como ferramenta psicológica, algo que os humanos usam para dar sentido às suas experiências e também para expressá-las. Dessa forma, a linguagem é um meio de transformação da experiência em conhecimento cultural, de expressão e de fazer-se compreender.

\subsection{A cognição de professores de línguas numa perspectiva sociocultural}

Conforme relatamos no início deste capítulo, adotaremos, nesta tese, a visão de crenças como componente da cognição de professores de línguas, que foi definida por Borg (2006) como "um termo inclusivo, que se refere às redes de conhecimento, pensamentos e crenças construídas por professores de línguas ao longo de seu trabalho”. O autor argumenta que essas redes de conhecimento são "complexas, orientadas pela prática, pessoais e sensíveis ao contexto" independentes do estágio profissional do professor ou do contexto de ensino de línguas em que ele "atue, pense e desenvolva conhecimentos ou crenças sobre qualquer aspecto de seu trabalho" 21 (p. 272).

Neste sentido, a investigação das crenças desde a perspectiva da cognição de professores tem como escopo entender como eles pensam, sabem e acreditam. A principal

\footnotetext{
${ }^{21}$ No original: "an inclusive term referring to the complex, practically-oriented, personalized, and contextsensitive networks of knowledge, thoughts and beliefs that language teachers draw on their work".
} 
preocupação, portanto, encontra-se na busca pela compreensão dos processos mentais que guiam as ações dos professores, ou seja, uma dimensão do ensino que não é diretamente observável.

Ao discorrer acerca das origens da pesquisa em cognição de professores, Borg (2006) nos apresenta que esta área remonta há mais de 30 anos e, no caso dos estudos da cognição de professores de línguas estrangeiras, só se consolidou na década de 1990.

Ao apresentar uma evolução diacrônica desta área de conhecimento, o autor cita que na década de 1960, a pesquisa relacionada ao processo de ensino-aprendizagem tinha como foco a busca de comportamentos eficazes de ensino que resultassem em uma maior aprendizagem (normalmente quantificada por meio de testes de desempenho). Este modelo de pesquisa ficou conhecido como abordagem processo-produto e partia do pressuposto de que o aprendizado era um produto do ensino e, neste sentido, o objetivo era identificar comportamentos efetivos na crença de que eles poderiam ser utilizados como modelos e aplicados universalmente pelos professores nos mais variados contextos.

$\mathrm{Na}$ década de 1970, como fruto dos avanços das pesquisas em psicologia cognitiva, essa visão de ensino focada no produto começou a ser questionada. A psicologia cognitiva destacou relações complexas entre o que as pessoas fazem e o que elas sabem e acreditam. Dessa forma, pesquisadores da área educacional tornaram-se mais conscientes de que, no ensino, a atividade mental dos professores desempenhava um papel fundamental em suas escolhas no dia a dia da sala de aula, o que implica conceber os professores não como "robôs que simplesmente implementavam, sem pensar, currículos, projetados por outros, mas sim, os professores exerciam influências em seus contextos de sala de aula - eles tomavam decisões, tanto antes como durante o ensino ${ }^{22}$ " (BORG, 2009, p. 1).

Houve, com isso, o início do despertar para a compreensão da influência da apropriação das propostas oficiais por parte dos professores em seus contextos de ensino e, como consequência, um deslocamento das perguntas de pesquisa. A visão tradicional que buscava compreender "o que os professores fazem?", agora se preocupa em entender "o que eles pensam?", “quais as decisões que eles tomam? e por quê??". Diante da singularidade de cada contexto específico de ensino-aprendizagem, já não bastam noções de comportamentos de

\footnotetext{
${ }^{22}$ No original: "robots who simply implemented, in an unthinking manner, curricula designed by others; rather, teachers exerted agency in the classroom - they made decisions, both before and while teaching".
} 
ensino universalmente aplicáveis. É nesta perspectiva que esta tese de doutoramento teve como meta um estudo empírico, envolvendo professores em formação incial no Cariri Paraibano.

Borg (2006) destaca 1975 como um ano-chave, que marcou o início da tradição em pesquisa acerca da cognição de professores, quando um painel influente de acadêmicos, convocado como parte de uma conferência nacional de educação nos Estados Unidos da América, deliberou sobre o valor deste campo de investigação e concluiu em seu relatório que:

é óbvio que o que os professores fazem é dirigido em grande medida, pelo que eles pensam.... Na medida em que o comportamento observado ou pretendido no ensino é "impensado", não faz uso de atributos mais humanos originais do professor. Ao fazê-lo, torna-se mecânico e pode muito bem ser realizado por uma máquina. Se, no entanto, o ensino é feito e, com toda probabilidade, continuará a ser feito por professores humanos, a questão das relações entre pensamento e ação se torna crucial $^{23}$ (Instituto Nacional de Educação de 1975, p. 1 apud BORG, 2006, p.7).

Este documento argumentava que, para entender os professores, os pesquisadores precisavam estudar os processos psicológicos por meio dos quais os professores dão sentido ao seu trabalho.

O autor apresenta que a ênfase nos processos cognitivos foi uma ruptura importante com os pontos de vista dominantes na época acerca do ensino e dos professores. Para ele, o ensino não estava mais sendo visto apenas em termos de comportamentos, mas sim, de forma reflexiva, e os professores não estavam sendo vistos como implementadores mecânicos de receitas externas, mas como participantes ativos, reflexivos e decisórios.

A partir deste marco de 1975, houve iniciativas de financiamento para investigações que contemplassem a cognição de professores e, como resultado, houve um crescimento rápido durante as décadas de 1980 e 1990 de pesquisa examinando diversos aspectos da dimensão psicológica do ensino.

Termos como conhecimento do professor, conhecimento pedagógico do conteúdo e conhecimento pessoal prático tornaram-se dominantes na pesquisa educacional acerca da cognição do professor, de forma que, na década de 1980, o estudo dos processos mentais dos

\footnotetext{
${ }^{23}$ No original: "it is obvious that what teachers do is directed in no small measure by what they think....To the extent that observed or intended teaching behaviour is "thoughtless", it makes no use of the human teacher's most unique attributes. In so doing, it becomes mechanical and might well be done by a machine. If, however, teaching is done and, in all likelihood, will continue to be done by human teachers, the question of relationships between thought and action becomes crucial".
} 
professores se consolidou como área de pesquisa e, dessa forma, "o valor da compreensão não só do que os professores fazem, mas também como eles pensam/acreditam foi amplamente reconhecido e isso se refletiu no volume de pesquisas realizadas sobre estas questões ${ }^{24}$, (BORG, 2009, p. 12).

A partir de um levantamento no corpo de pesquisas reunidas na área da cognição de professores, Borg $(2009$, p. 3) destaca alguns pontos comuns acerca da natureza da cognição do professor e a sua relação com o que os professores pensam, sabem, acreditam e fazem: i) As próprias experiências dos professores como aprendizes podem influenciar intensamente suas cognições; ii) o que e como aprendem os professores durante sua formação recebem a influência dessas cognições; iii) Essas cognições exercem o papel de um filtro mediante o qual novas informações e experiências são interpretadas pelos professores; iv) elas podem superar os efeitos da influência da formação de professores naquilo que eles fazem em sala de aula; v) elas podem ser resistentes à mudança se estiverem profundamente enraizadas; vi) elas podem exercer uma influência longa e contínua nas práticas educativas dos docentes; vii) elas nem sempre refletem o que os professores fazem na atuação docente em sala de aula; viii) interagem de modo bidirecional com a experiência (por. ex., as crenças influenciam as práticas, mas as práticas também podem levar a mudanças nas crenças).

O impacto do contexto na cognição do professor e, consequentemente, em suas práticas, bem como a relação entre a cognição e as práticas de sala de aula são pontos importantes apresentados por Borg (2006).

O ensino de línguas nos é apresentado pelo pesquisador como um processo no qual há interações dinâmicas entre cognição, contexto e experiência. A cognição, na visão do autor, está entrelaçada aos conhecimentos, pensamentos, crenças, formando um sistema complexo e dinâmico, ancorada nas vivências, práticas e sensíveis ao contexto conforme podemos observar no quadro 7:

\footnotetext{
${ }^{24}$ No original: "The value of understanding not only what teachers do but also how they think was widely recognized and this was reflected in the volume of research undertaken into these issues".
} 
História pessoal e experiências especificas de sala de aula, que definem preconcepções de educação (por exemplo, o que é ser professor, o que é ensinar).
Pode impactar cognições existentes, embora tal impacto seja menor quando tais cognições

são desconhecidas.

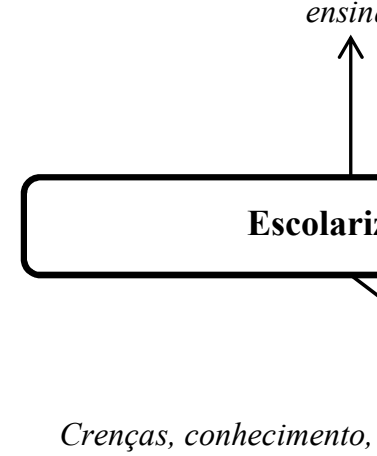
teorias, atitudes, suposições, concepções, princípios, pensamentos, tomadas de decisão.

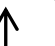


porque as cognições são também formadas a partir do que ocorre nas práticas de sala de aula [e fora delas]" (p. 116).

Borg (2006) argumenta que os contextos (social, institucional, instrucional, físico) pelos quais o professor transita e atua exercem profundo impacto em suas cognições. Neste sentido, o contexto pode interagir com o professor de maneira a: i) proporcionar mudanças na cognição do professor; ii) influenciar alterações das práticas do docente sem, necessariamente, alterar sua cognição. Dessa forma, na pesquisa a respeito da cognição de professores, o estudo dos fatores contextuais torna-se primordial, pois pode propiciar uma interpretação mais ampla e adequada dos dados e evidenciar que cognição, prática e contexto influenciam-se mutuamente.

\subsection{Por uma definição das crenças}

É sabido que os estudos acerca das crenças que permeiam o complexo processo de ensino-aprendizagem vêm desde os tempos mais remotos e pertencem a várias disciplinas como a filosofia, sociologia e psicologia, dentre outras ciências. É possível que o trabalho pioneiro nesta linha, dentro da psicologia, seja o de James (1890), apontado por Scheib (1970). Neste contexto, postula-se o homem como construtor da verdade que fundamenta suas ações de forma a instituir como verdadeiro o seu discurso. A partir desta visão, Bedran (2008, p. 21) apresenta que "as crenças estão relacionadas com a construção da verdade mental e as ações que auxiliam a tornar verdadeiro o discurso apresentado pelo homem”. No que concerne à nossa pesquisa, entendemos "verdade mental" como a "formação dos conceitos" postulada por Vigotski (2001), que será apresentada nos próximos itens.

No âmbito da LA, Barcelos $(2007$, p.111) destaca que a pesquisa a respeito das crenças no contexto de ensino-aprendizagem de línguas iniciou-se por volta dos anos 1980 no exterior e em meados dos anos 1990 no Brasil, com as defesas das primeiras dissertações sobre crenças em programas de pós-graduação em LA (PUC-SP e UNICAMP). Segundo a pesquisadora, do início da década de 1990 até 2007 existiam, em nosso território, por volta de 50 dissertações e teses sobre esta temática. Para ela, a produção nacional nesta área pode ser dividida em três períodos: um período inicial que vai de 1990-1995, um de desenvolvimento e 
consolidação que vai de 1996 a 2001, e o período de expansão que se inicia em 2002 e vem até o presente.

Pajares (1992) cita não ser possível pesquisar crenças sem, antes, definirmos este conceito e termos clara a sua conexão com outros termos parecidos. Desta forma, neste momento, nos dedicaremos a algumas das definições de teóricos da LA, de forma a apresentar a concepção de crenças que compartilharemos nesta pesquisa.

Por conta do volume de pesquisas feitas no Brasil e no exterior, bem como a profusão terminológica envolvendo a questão, diversos pesquisadores relataram não ser fácil a tarefa de definir as crenças, o que - de certa forma - evidencia a relevância e importância da promoção de pesquisas no âmbito da LA.

Diante da enorme quantidade de termos presentes na LA para nomear as crenças e tendo em vista a complexidade que é a investigação delas no campo de ensino-aprendizagem de línguas, Woods (1996) lança mão da metáfora "floresta terminológica".

Não temos, por limitação de tempo e espaço, a intenção de retomar, neste trabalho, de maneira detalhada cada um dos termos e definições desta grande floresta terminológica levantamento que o leitor poderá encontrar em Bedran (2008) e Silva (2011), por exemplo.

Sintetizamos, na imagem 2, a seguir, os principais termos encontrados na literatura da área e que, neste trabalho, serão compreendidos, já que não existem sinônimos perfeitos, como conceitos que gravitam na mesma esfera, compondo, desta forma, o campo semântico das crenças num sistema dinâmico. De acordo com a lente teórica adotada, qualquer um desses termos pode ganhar destaque e ocupar o centro. Dito de outra maneira, no caso da linha teórica que adotamos para esta pesquisa o termo crenças ocupará lugar de destaque. Se abordado pelo olhar da psicologia social, o termo representações poderia ocupar o centro. Já o olhar da filosofia poderia privilegiar o termo mitos, os marxistas poderiam ceder o ponto central para a palavra ideologias, e assim por diante. 


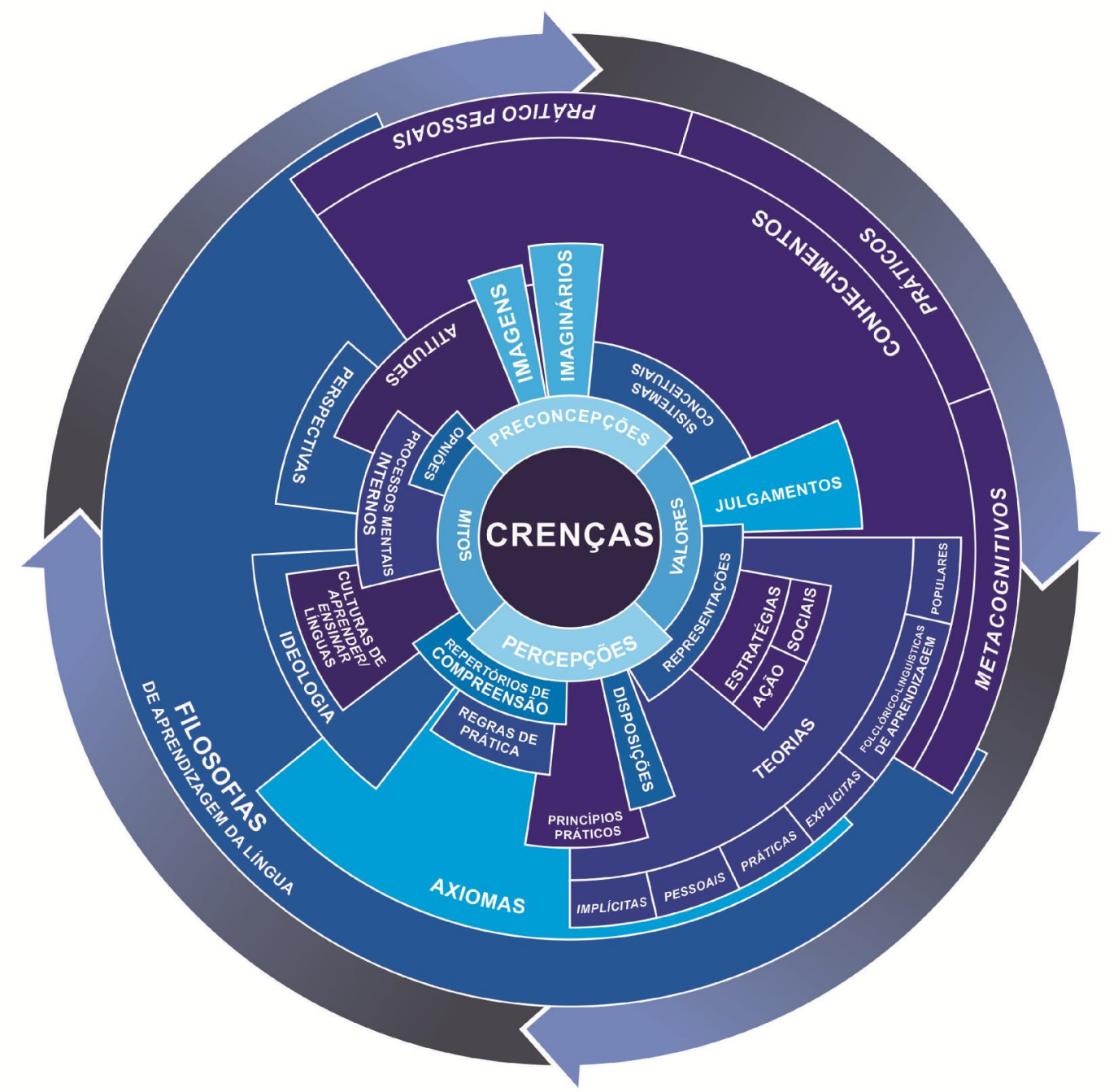

Imagem 2: Campo semântico com as diversas terminologias utilizadas para se referir as crenças que permeiam o complexo processo de ensino-aprendizagem de línguas. Elaboração nossa, a partir de diversas fontes, representadas - principalmente - nos levantamentos de Almeida Filho (1993), Barcelos (1995, 2001), Bedran (2008), Cardoso (2002), Gimenez (1994), Pajares (1992), Silva (2007). 
Ressaltamos que a proliferação terminológica ao mesmo tempo em que confunde, destaca a relevância dos estudos e pesquisas nesta área. As definições existentes para as crenças na literatura são diversificadas o que, conforme nos apresenta Pajares (1992), ocorre pelo fato de elas serem usadas em campos diversos.

Para esta tese, acreditamos não ser necessário cunhar um termo novo em meio a tantos outros já existentes na prolífica literatura acerca do tema. Por conta disso, compartilharemos da definição de Barcelos (2006), já que corrobora com o sentido adotado para esta pesquisa:

[As crenças são] uma forma de pensamento, como construções da realidade, maneiras de ver e perceber o mundo e seus fenômenos, coconstruídas em nossas experiências e resultantes de um processo de interpretação e (re)significação. Como tal, crenças são sociais (mas também individuais), dinâmicas, contextuais e paradoxais (p.18).

No verbete "crenças na aquisição de segundas línguas" com foco no professor, preparado para The Encyclopedia of Applied Linguistics, Barcelos \& Kalaja (2013b, p. 1) apresentam ser uma das maiores controvérsias em relação ao tema a distinção entre crenças e conhecimentos, defendida por alguns pesquisadores e ignorada por outros.

Neste sentido, cabe destacar que não adotaremos, para esta tese, a distinção entre crenças e conhecimentos, já que comungamos da abordagem das crenças como componente da cognição, conforme apresentado por Borg (2006), que - por sua vez tem sua origem na interação social, moldada por processos culturais e sociopolíticos e, neste sentido, não só a linguagem, mas também o pensamento é metafórico.

Barcelos (2006) argumenta que as pessoas pensam em conjunto com outras. Assim sendo, a cognição é construída socialmente por meio da colaboração e, portanto, "nem sempre é possível fazer distinção entre o que o professor sabe, pensa ou acredita" (p. 18).

Neste sentido, as crenças devem ser investigadas tendo em vista a interação, de forma a promover a interação e a interconexão entre crenças e ações. Barcelos (2001) já sinalizava que a pesquisa sobre as crenças que permeiam o complexo processo de ensino-aprendizagem de línguas necessitava ir além da simples descrição de crenças como indicadores de um comportamento futuro.

A pesquisadora argumentava que era preciso uma investigação contextualizada das crenças que buscasse compreender como estes construtos interagem com as ações dos alunos, no nosso caso, professores em formação inicial, e que funções exercem em suas experiências de aprendizagem dentro e fora de sala de aula. 
Como o conhecimento não pode ser separado da ação, a estudiosa citava que uma pesquisa a respeito de crenças deveria envolver: (a) suas experiências e ações; (b) suas interpretações sobre essas experiências; e (c) o contexto social e como esse contexto molda as suas experiências (BARCELOS, 2001).

\subsection{Um perfil das crenças}

Neste item, a partir de uma breve revisão bibliográfica ${ }^{26}$, nos dedicaremos a traçar um perfil das crenças. Barcelos \& Kalaja (2013a, p. 2) sintetizam as principais características das crenças alegando que: a) são contextuais, pessoais, experienciais, sociais, cognitivas e construídas em práticas discursivas; b) são descritas como dinâmicas e variáveis de uma situação para outra; c) estão intrinsecamente relacionadas às ações, que as orientam e influenciam mutuamente; d) são parte da capacidade interpretativa de um professor para dar sentido ao mundo social que o rodeia e embasar suas soluções e encaminhamentos aos problemas com os quais se depara; e) podem, em alguns casos, ser mais resistentes à mudança e; f) desempenham um papel importante em ajudar os professores a compreender a si próprios e aos demais envolvidos no processo de ensino-aprendizagem de línguas.

Dessa forma, as crenças fornecem significado, dão estrutura, ordem, direção e valores compartilhados. Elas também ajudam os indivíduos a se identificarem com grupos e sistemas sociais, de forma a reduzir a dissonância e confusão.

Reunimos no quadro 8, a seguir, as principais características encontradas que corroboram com a concepção de crença adotada para este estudo:

\footnotetext{
${ }^{26}$ Barcelos (2001, 2006); Barcelos \& Kajala (2003, 2013a e b); Dufva (2003); Dufva, Kajala \& Barcelos (2003); Honselfed (2003); dentre outros.
} 


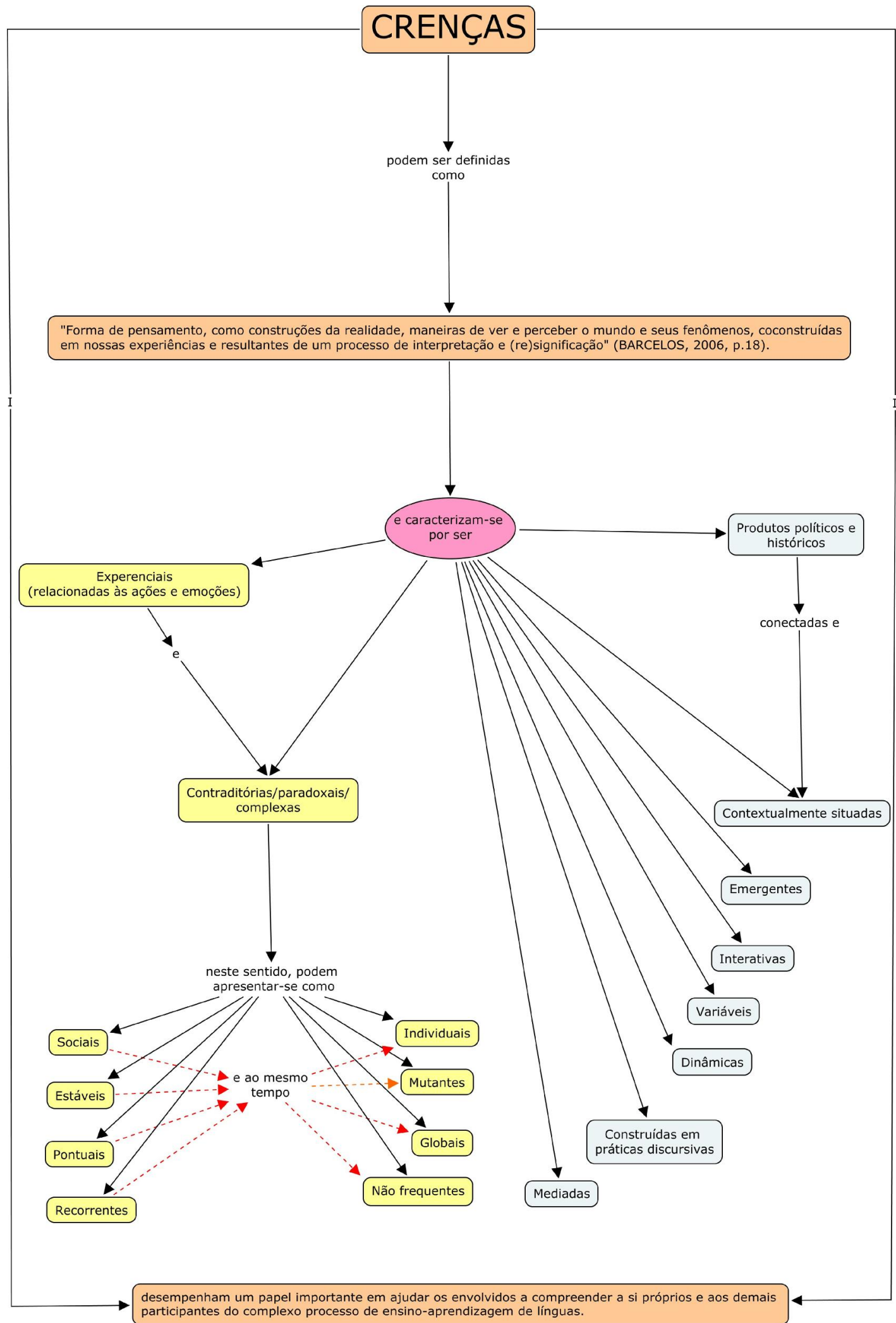

Quadro 8: Principais características das crenças. Elaboração nossa, a partir da revisão bibliográfica. 
Barcelos (2001, p. 73) relata que as crenças são "pessoais, contextuais, episódicas e com origem nas nossas experiências, na cultura e no folclore"; segundo ela, as crenças também podem ser internamente inconsistentes e contraditórias. Em estudo posterior, Barcelos e Kalaja (2003, p. 233) nos apresentaram as crenças como sendo dinâmicas, emergentes, experienciais, mediadas, paradoxais, relacionadas à ação de uma maneira indireta e complexa, de forma que "as crenças exercem grande influência nas ações, mas as ações também podem influenciar as crenças" (BARCELOS, 2010, p.25).

As autoras argumentam que as crenças são dinâmicas porque sofrem mudanças ao longo do tempo e da nossa trajetória de vida, já que vivemos constantes metamorfoses. $\mathrm{O}$ próprio conhecimento acumulado a respeito do processo de ensino-aprendizagem de línguas e, consequentemente, as nossas crenças acerca dele vão mudando ao longo do tempo. Neste sentido, Dufva (2003), argumenta que essa dinamicidade não significa que as crenças são geradas imediatamente, mas são sempre ancoradas em eventos significativos como "incidentes do passado, pessoas que foram significativas, assuntos que lemos ou ouvimos na mídia ou opiniões de nossos professores na escola" (p. 143).

Como consequência da dinamicidade, as autoras citam serem as crenças emergentes, socialmente construídas e situadas contextualmente, já que elas não se encontram em nossas mentes como uma estrutura mental pronta e fixa, mas mudam e se desenvolvem na medida em que interagimos e modificamos nossas experiências e, somos, ao mesmo tempo modificados por elas: "as crenças tornam-se articuladas à medida que agimos e falamos sobre elas" (BARCELOS \& KALAJA, 2003, p. 233). Nesta mesma linha, "falar sobre alguma coisa significa, ao mesmo tempo, ouvir a nós mesmos" (DUFVA, p. 144). Dessa forma, foram de fundamental importância para os participantes da nossa pesquisa os momentos que propiciaremos, com o auxílio do cinema como artefato simbólico socialmente construído, para o fomento da reflexão, de forma a reconhecer e reformular suas crenças num processo constante de interação entre conceitos científicos e conceitos cotidianos.

Neste sentido, Barcelos (2006 p. 19) argumenta que as crenças incorporam as perspectivas sociais, pois nascem no contexto da interação e na relação com os grupos sociais. A autora cita Kramsch (2003), para quem as "crenças não só representam uma realidade social, mas constroem essa realidade” (p. 111). A partir deste ponto de vista, não deveríamos buscar ocultar a inconsistência e variabilidade das crenças mas, pelo contrário "dar um relato contextualizado das crenças, levando em conta sua variabilidade, contingência e inconsistência" (p. 111). 
Assim, na perspectiva sociocultural, o desenvolvimento profissional do professor em formação inicial estará diretamente ligado à interação com seu meio, mediado por pessoas e artefatos culturais. Dessa forma, são fundamentais as oportunidades oferecidas por seu contexto e as experiências vivenciadas em seu meio. Temos, neste processo, a interação entre alunos, alunos e professores, alunos e artefatos simbólicos, alunos-professores e seus alunos das experiências de prática de ensino como estratégias fundamentais potencializadoras do desenvolvimento e, neste processo, "as crenças dos aprendizes são parte das construções e reconstruções de suas experiências" (HOSENFELD, 2003, p. 39).

A mediação, segundo a perspectiva sociocultural, exerce papel fundamental, já que, para Vigotski, o homem apreende o mundo não de forma direta, mas sim de forma mediada, por intermédio de instrumentos, signos e do “outro". Neste sentido, Dufva (2003) apresenta as crenças como meios de mediação usados para regular a aprendizagem e propiciar a solução de problemas.

Barcelos $(2000,2003)$ ressalta que as crenças podem atuar como instrumentos de potencialização ou como obstáculos ao processo de ensinar e aprender línguas. Neste sentido, as crenças são "sociais, mas também individuais e únicas; são compartilhadas, emocionais, diversas, mas também uniformes" (BARCELOS \& KALAJA, 2003, p. 233) e podem favorecer ou prejudicar o complexo processo de ensino-aprendizagem de uma língua estrangeira.

\subsection{Potencialidades e limitações para a (re)significação e (re)construção de crenças}

Nosso trajeto, neste item, está baseado - principalmente - em Barcelos (2007) que tece considerações e reflexões a respeito da mudança de crenças de alunos e professores envolvidos no complexo processo de aprender e ensinar línguas pela lente teórica da LA. São poucos os estudos, em contexto brasileiro, dedicados a colaborar na construção de conhecimentos a respeito das condições e dos fatores que atuam na mudança de crenças de professores. Neste sentido, tivemos contato com as pesquisas de Blatyta (1999), Araújo (2004), Kudiess (2005) e Pessoa \& Sebba (2006). Estamos diante de um tema complexo e que conta com poucos trabalhos no Brasil que discutem teoricamente o conceito de mudança relacionado às crenças. 
A importância de se saber sobre mudança está relacionada ao próprio contexto educacional. Afinal de contas, educar é provocar mudanças ou criar condições para que elas aconteçam, sempre partindo de um lugar que, no caso, são nossas crenças a respeito do mundo que nos cerca (BARCELOS, 2007, p. 110).

Ao traçar uma revisão a respeito das características das crenças, a autora apresenta a visão das crenças como uma estrutura mental pronta e fixa já como ultrapassada e argumenta que, na abordagem contextual $^{27}$, estudos apontam a possibilidade de modificação, desenvolvimento e ressignificação de crenças "à medida que interagimos e modificamos nossas experiências e somos, ao mesmo tempo, modificados por elas" (p. 114).

A pesquisadora busca compreender mudanças relacionando este termo a vários sentimentos como dúvida, incerteza, ambiguidade, caos e lança mão de outros autores para traçar considerações relevantes a respeito da mudança: i) nem sempre significa alteração na ação, mas sim, na consciência do que se faz; ii) pode não ser uma maneira diferente de ensinar ou aprender, mas de pensar a respeito de como se ensina ou se aprende; iii) é um processo lento, demanda tempo e é resultado de um processo de reflexão que inclui novas formas de pensar e compreender nossas ações.

Compartilharemos, nesta tese, da visão de mudança apresentada por Barcelos (2007) a partir das reflexões de Simão et. al. (2005): um processo complexo, interativo e de múltiplas dimensões, que pressupõe a interação entre fatores pessoais e contextuais, intrinsecamente ligado à aprendizagem e ao desenvolvimento, incluindo mudanças ao nível das crenças e das práticas e a articulação entre ambas.

Borg (2006), ao apresentar o esquema com os elementos e processos na cognição de professores, destacou a importância dos fatores contextuais no sistema. No que se refere à mudança de crenças não seria diferente, nossa atuação é feita via interação em contextos sociais e permeada por nossas crenças. Dessa forma, somos sempre influenciados por fatores contextuais.

A partir do trabalho de Rokeach (1968) que busca representar a metáfora de um átomo para comparar com a estrutura das crenças, as imagens 3 e 4, de Barcelos (2007), apresentam as crenças como dotadas de uma estrutura complexa, formada por sistemas e teias. $\mathrm{Na}$ imagem 3 podemos observar que as crenças se organizam em centrais e periféricas. Nesta

\footnotetext{
${ }^{27}$ Apresentamos, na página 43 desta tese, um quadro com as características, vantagens, e desvantagens das três abordagens (normativa, metacognitiva e contextual) para o estudo das crenças.
} 
perspectiva, as crenças mais centrais são mais resistentes à mudança e possuem quatro características:

(a) são mais interconectadas com outras e, por esse motivo, se comunicam mais entre si e, dessa forma, trazem mais consequências para outras crenças; (b) estão mais relacionadas com a identidade e com o 'eu' do indivíduo; (c) são compartilhadas com outros; e (d) derivam de nossa experiência direta ("ver para crer") (BARCELOS, 2007, p. 117).

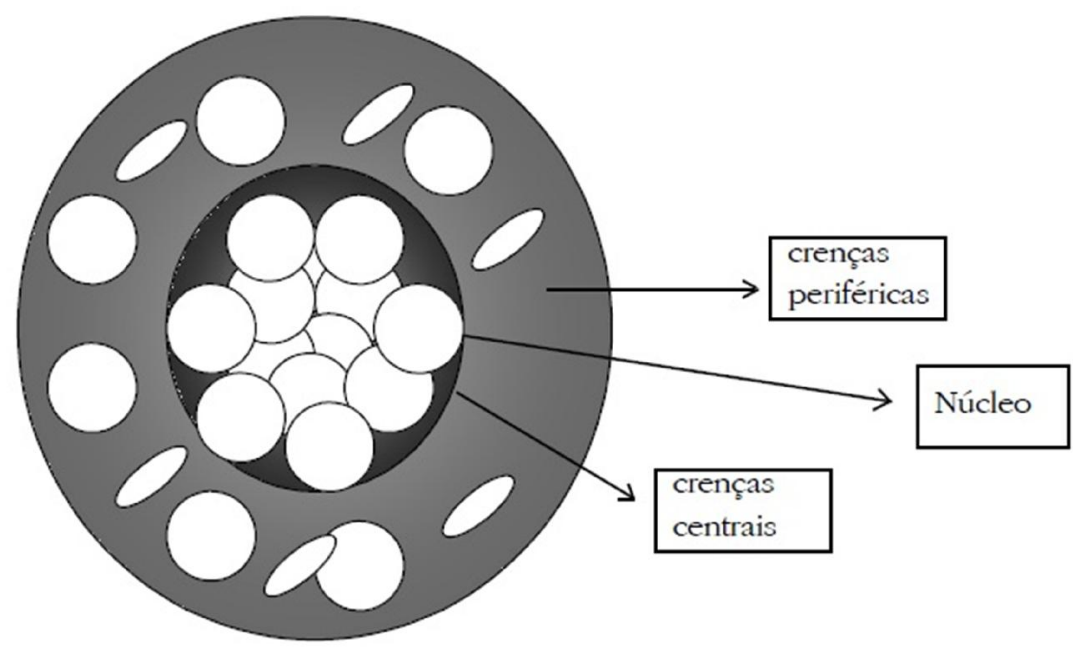

Imagem 3: Representação da estrutura das crenças como crenças centrais e periféricas a partir da metáfora do átomo de Rokeach (1968). Fonte: Barcelos (2007, p. 118).

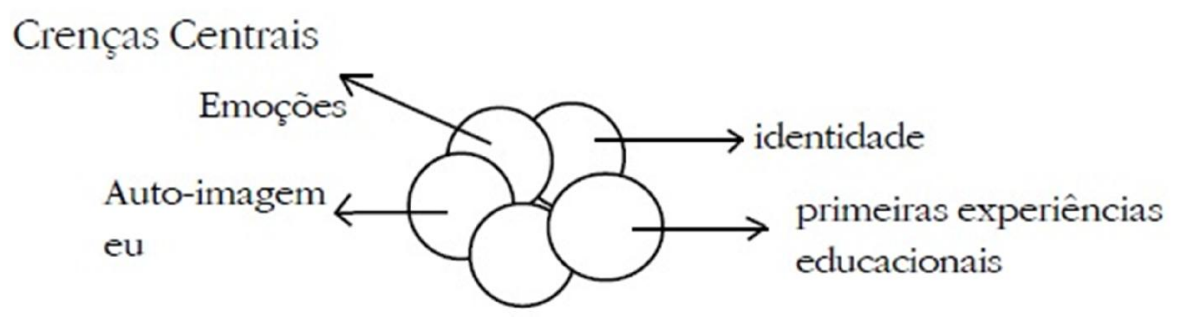

Imagem 4: Detalhamento da estrutura central das crenças. Fonte: Barcelos (2007, p. 118).

É consenso entre diversos pesquisadores que a natureza das crenças é um dos elementos que torna a mudança mais difícil e complexa: 
Quanto mais centrais as crenças (ou seja, incorporadas mais cedo, mais relacionadas com nossa emoção e identidade, e mais inter-relacionadas com as outras crenças), mais difícil mudá-las porque uma mudança (adição ou abandono de uma crença) implicaria uma mudança em todo o sistema, conforme afirmado por Rokeach (1968) e Woods (1996). De acordo com Woods, a mudança de uma crença torna-se difícil então, pois, como estão interconectadas umas às outras, é preciso que haja uma desconstrução de algumas crenças para que outras possam ser incorporadas (BARCELOS, 2007, p. 118).

Pajares (1992) cita Posner et al. (1982) para refletir a respeito da substituição de uma crença. Neste sentido, os autores argumentam que a insatisfação com determinada crença existente é o ponta pé inicial para que ela seja substituída por outra. Para que a troca ocorra, a nova crença deve ser inteligível, plausível e consistente com as demais que compõem o sistema de crenças do indivíduo.

A partir do que foi apresentado, Barcelos (2007) recomenda, nos processos investigativos da alteração de crenças, a observação, análise e descrição o mais detalhada possível de como crenças e ações se inter-relacionam em determinado contexto.

Ao apresentar as condições para se mudar as crenças, Barcelos (2007) retoma a sugestão de Borg (2003) a respeito da importância de que a relação entre mudança cognitiva e comportamental e o mapeamento da mudança no processo de cognição dos professores seja objeto de estudo.

Blatyta (1999), a partir da operação global do ensino de línguas de Almeida Filho (1993) sugere a substituição do termo "ruptura" por "ressignificações" buscando definir a maneira como as mudanças ocorrem, de forma lenta e processualmente, como fruto de uma relação dialógica.

Pessoa \& Sebba (2006) propõem que as metamorfoses nas crenças e ações não ocorrem com facilidade e alertam estarmos diante de um processo gradual. Elas destacam a importância de se promover oportunidades de interação e de explicitação das crenças, bem como favorecer o caminho da reflexão na e sobre a prática de forma a contribuir para a mudança:

Mudar é difícil, mas é preciso. O professor não muda da noite para o dia, com pacotes de formação prontos. Ele muda procedimentos simples - a aula é feita deles - para alterar suas teorias mais simples e elas irem convencendo-o, aos poucos, de que sua filosofia de ensino deve mudar para obter resultados de aprendizagem mais eficazes. Não parece haver mágica no caminho do desenvolvimento profissional de professores (p. 62). 
A partir da revisão dos trabalhos de Araújo (2004), Pessoa \& Sebba (2006) e Blatyta (1999), Barcelos (2007) relaciona, respectivamente, movimentos de reconstrução, mobilização de teorias pessoais e relação dialógica, de forma a apresentar que "a mudança das crenças de professores é um processo dinâmico que envolve idas e vindas, reconstrução e reavaliação" (p. 124).

Neste sentido, nossa pesquisa buscou, ao longo do semestre 2013.2, possibilitar vários momentos para que a reflexão e a explicitação de crenças fossem a mola propulsora para a ressignificação ou mudança dessas crenças.

Orientamo-nos em Woods (2003) na condução de nossas ações e, a partir da utilização do cinema como artefato semiótico mediador, buscamos: i) explicitar as crenças para análise, inspeção e reflexão; ii) promover situações contextualizadas para que os alunos participantes se engajassem na confrontação e ressignificação de seus sistemas de crenças; iii) buscar proporcionar experiências diferenciadas com o apoio da sétima arte, sempre explicando os objetivos de cada sequência didática.

Kudiess (2005) afirma que o professor tende a manter as crenças que obteve como aluno de LE, ao passo que aquelas adquiridas na sua prática, ou em cursos de formação continuada, são menos resistentes à mudança. Neste sentido, um ponto positivo de nossa pesquisa é proporcionar reflexões com o objetivo de propiciar a potencialização da compreensão do processo no qual estão envolvidos os participantes durante a graduação, de forma a construir e/ou (re)construir ou (re)significar crenças favoráveis ao processo.

Não é possível fazer grandes afirmações sobre como as crenças evoluem, mas o que se percebe é que estas, sempre que em contato com novas experiências, passam por um processo de "amadurecimento", seja através dos questionamentos dos professores, reflexões, conflitos, dúvidas ou simplesmente pela assimilação de novos conhecimentos, informações e aprendizagens, podendo vir a se transformar em outras crenças (sofrem mudanças) ou acomodar novas informações, fazendo com que os professores adaptem as suas crenças a uma situação específica (KUDIESS, 2005, p. 79).

Nas atividades propostas ao longo do semestre 2013.2, tivemos a interação e a reflexão como molas propulsoras de possíveis mudanças e ressignificações, num processo contínuo de avaliação e reflexão na e sobre a ação, encorajando a conscientização a respeito das crenças dos participantes, mediadas pelo cinema e à luz da teoria especializada, de forma a tornar as crenças explícitas à autoanálise e possíveis (re)construções ou (re)significações.

Em relação ao conceito de mudança de crenças, após consistente reflexão e revisão bibliográfica, Barcelos (2007) conclui que: 
é importante lembrar que (...) ela pode se dar em duas acepções: (a) uma consciência do que se faz, seguida de uma ressignificação ou reafirmação da crença e da prática atual. Nesse caso, a mudança não necessariamente significa sempre fazer algo novo ou diferente, mas envolver-se na reflexão e conscientização de como compreendemos o que fazemos; e (b) acomodação da crença e mudança de comportamento ou da ação (p. 129).

Temos consciência de que a mudança é um processo complexo e multidimensional que demanda tempo e depende das percepções de todos os envolvidos no complexo processo de ensinar e aprender línguas. Neste sentido, a autora destaca que compreender o processo dinâmico e multidimensional da mudança demanda "um conhecimento a respeito da própria estrutura cognitiva e social das crenças. As crenças mais centrais, que são baseadas em nossa experiência anterior, mostram forte relação com nossa identidade e nossas emoções” (p. 130) e cita que nossas ações ao sugerir mudanças nas crenças dos envolvidos sejam cautelosas, já que "é preciso antes conhecer a sua história de aprendizagem e de ensino e as emoções de todo esse processo, sem deixar, entretanto, de estimulá-los à criticidade necessária para o exercício da docência” (p. 130).

Neste sentido, a sala de aula torna-se um local privilegiado, na perspectiva sociocultural, não somente como ambiente adequado para aprender e ensinar línguas, inclusive "para se aprender a pensar sobre a aprendizagem ou sobre fatores desse processo, como as crenças, os estilos e as estratégias de aprendizagem e suas mudanças" (p. 131).

As atividades, neste contexto, podem propiciar oportunidades para conscientização a respeito do que os envolvidos creem a respeito da linguagem e do aprendizado, bem como as consequências destas concepções para o seu desempenho, sua identidade e suas escolhas como aprendiz e professor.

\subsection{Crenças e formação de conceitos: uma aproximação teórica}

Diante da perspectiva sociocultural adotada para esta tese, na qual concebemos as crenças como um dos componentes da cognição de professores de línguas, nos parece oportuno, neste momento, compartilhar da visão de Vigotski (2001) no que se refere à formação dos conceitos e traçar uma possível aproximação desta visão com as crenças.

Neste intuito, focaremos as crenças como parte do que Vigotski intitula conceitos cotidianos; mas apenas parte, isto é, as crenças são parte dos conceitos cotidianos, que, por sua vez, não são constituídos somente por crenças. 
A formação dos conceitos discutida na obra vigotskiana organiza as principais proposições acerca do desenvolvimento humano, ou seja, as relações intrínsecas entre o pensamento e a linguagem, bem como o papel fundamental da cultura como mediadora na constituição da forma de funcionamento psicológico individual e o processo de internalização de significados e conhecimentos elaborados socialmente.

Nesta perspectiva, compreendemos os conceitos "como um sistema de relações e generalizações contidos nas palavras e determinados por um processo histórico-cultural" (REGO, 2000, p. 76):

são construções culturais, internalizadas pelos indivíduos ao longo de seu processo de desenvolvimento. Os atributos necessários e suficientes para definir um conceito são estabelecidos por características dos elementos encontrados no mundo real, selecionados como relevantes pelos diversos grupos culturais. É o grupo cultural onde o indivíduo se desenvolve que vai lhe fornecer, pois, o universo de significados que ordena o real em categorias (conceitos), nomeadas por palavras da língua deste grupo (OLIVEIRA, 1992, p. 28).

Assim como ocorre em relação às crenças, existe uma inter-relação dos conceitos em um sistema. Neste sentido, Vigotski (2001) argumenta "um conceito não ser uma formação isolada, ossificada, imutável, mas parte ativa de um processo intelectual, constantemente mobilizada ao serviço da comunicação, do conhecimento e da resolução de problemas (p. 57)". O pensador russo acrescenta:

Os conceitos não se encontram depositados no cérebro (...) como ervilhas num saco, sem qualquer relação que os una. Se assim fosse, não seria possível nenhuma relação intelectual que exigisse uma coordenação de pensamentos, nem nenhuma concepção geral do mundo. Nem sequer poderiam existir conceitos separados enquanto tais; a sua própria natureza pressupõe um sistema (VIGOTSKI, 2001, p. 110).

A teoria sociocultural vigotskiana enfatiza a importância dos conceitos na aprendizagem. Johnson (2009, p. 20) argumenta que os conceitos não são fixos, mas desenvolvidos dinamicamente por meio do uso, de modo que são aprendidos ao longo do tempo e formados por meio de processos de síntese e análise, ao mover-se repetidamente entre o engajamento em atividade e raciocínio abstrato.

Os conceitos são divididos entre conceitos cotidianos e conceitos científicos. Os conceitos cotidianos podem ser subdivididos em duas categorias: espontâneos e nãoespontâneos, dependendo da sua acessibilidade à inspecção consciente. 


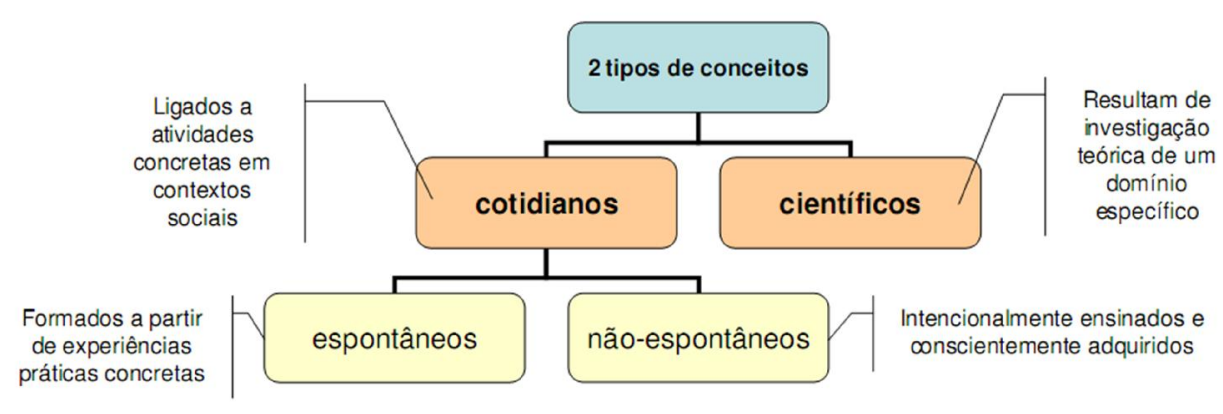

Imagem 5: Tipos de conceitos (Elaborada por Salomão, 2012, p. 49, a partir de Johnson, 2009).

Podemos afirmar que os conceitos cotidianos espontâneos têm sua formação condicionada a situações de experiências práticas de interação em contextos socioculturais. Dessa forma, em nossa pesquisa, quando os participantes repondem a perguntas como "defina língua estrangeira" e/ou "o que se sabe quando se sabe uma língua estrangeira", é bem provável que a resposta parta de sua experiência cotidiana, sem reflexão acadêmico-científica, conforme apresentamos no panorama do contexto de pesquisa, no capítulo 1 desta tese.

Em contrapartida, os conceitos cotidianos não-espontâneos são, na maioria das vezes, ensinados de forma intencional, sua formação envolve intencionalidade no ensino e implica no uso consciente dos mecanismos de processamento superiores. Os conceitos cotidianos, espontâneos ou não, estão relacionados aos contextos sociais concretos:

o desenvolvimento dos conceitos espontâneos e dos conceitos não espontâneos — se encontram relacionados e influenciam-se um ao outro permanentemente. Fazem parte de um único processo: o desenvolvimento da gênese do conceito, que é afetado por condições externas e internas variáveis, mas é essencialmente um processo unitário e não um conflito de formas de intelecção antagônicas e mutuamente exclusivas (VIGOTSKI, 2001, p. 86).

Neste sentido, um professor pode não ter aprendido as bases científicas da abordagem comunicativa com enfoque por tarefas, mas pode ter aprendido a trabalhar a partir de projetos, como, por exemplo, construir com seus alunos uma campanha publicitária, incluindo um guia turístico, na língua alvo para divulgar a região em que vivem, de forma a trabalhar com os estudantes todas as características deste gênero discursivo, bem como apresentar um recorte da gramática, fórmulas linguísticas e vocabulário necessários para desenvolver esta atividade. Dito de outra maneira, ele pode ter aprendido a aplicar a técnica, sem ter conhecimento sobre a teoria que a embasa. 
Como contraponto dos conceitos cotidianos, sejam eles espontâneos ou não espontâneos, temos que os conceitos científicos são resultados de pesquisas teóricas em domínios específicos. Johnson (2009, p. 21) cita que, quando entendidos dentro e por meio de conceitos cotidianos, os conceitos científicos permitem ir além das limitações de suas experiências cotidianas e possibilitam experienciar vivências novas em diversos contextos e situações: isso implica considerar que a apresentação de conceitos científicos, em contextos formais de ensino-aprendizagem, necessita ser contextualizada e estabelecer relações com ações concretas cotidianas. É neste sentido que, nesta tese, lançaremos mão do cinema como artefato cultural mediador das reflexões dos participantes em relação aos conceitos científicos do campo da aquisição/aprendizagem de uma língua estrangeira e da variação linguística.

Nesta linha, os conceitos espontâneos se desenvolvem de baixo para cima, isto é, das propriedades mais elementares às superiores. Já os conceitos científicos se desenvolvem das propriedades mais complexas e superiores às mais elementares, isto é, de cima para baixo.

No que concerne às implicações da perspectiva sociocultural no escopo de nossa pesquisa, isto é, da formação inicial de professores de E-LE, devemos ter em mente que se trata de um processo em constante construção e reformulação numa relação dialética, de contradição entre os conceitos cotidianos e científicos do que vem a ser linguagem, língua, língua estrangeira, variação linguística, unidade e diversidade na língua espanhola e de como se ensina e se aprende E-LE em contextos formais no território brasileiro, bem como em relação às contribuições do cinema neste processo.

Neste sentido, a distinção feita por Vigotski entre os diferentes tipos de conceitos têm implicações diretas para a formação de professores de línguas uma vez que, para se estabelecerem como profissionais, os professores precisam avançar dos conhecimentos empíricos e experienciais para práticas instrucionais teoricamente informadas:

O contexto formal de escolarização é visto, de uma perspectiva sociocultural, como um contexto exemplar, no qual a construção de conceitos emerge da instrução que liga as experiências cotidianas aos conceitos científicos. No entanto, a instrução formal não conduz de forma direta ao desenvolvimento de conceitos, os quais se desenvolvem gradativamente e dependem do gerenciamento do aprendiz e das contribuições e limitações do ambiente de aprendizagem (VIEIRAABRAHÃO, 2012, p. 462).

Ainda que distintos - conceitos cotidianos e científicos - estão estreitamente relacionados e se influenciam de forma mútua já que compõem um processo criativo e único de desenvolvimento da formação de conceitos. A mesma relação de reciprocidade pode ser 
estabelecida no vínculo língua materna - língua estrangeira já que uma pode influenciar mutuamente no aprimoramento da outra.

Rego (2000) nos apresenta que o processo de formação de conceitos, fundamental no desenvolvimento dos processos psicológicos superiores, é longo e complexo "pois envolve operações intelectuais dirigidas pelo uso das palavras (tais como: atenção deliberada, memória lógica, abstração, capacidade para comparar e diferenciar) (p. 78)”.

O aprendizado de um conceito demanda, além da captação de informações exteriores, uma intensa atividade mental por parte do sujeito. Dessa forma, "a gênese dos conceitos é um processo criativo e não mecânico e passivo; (...) um conceito surge e toma forma no decurso de uma complexa operação orientada para a resolução do mesmo problema" (VIGOTSKI, 2001, p. 58).

Neste raciocínio, um conceito não pode ser aprendido pura e simplesmente por meio de um treinamento mecânico, muito menos ser transmitido via ensino:

A experiência prática mostra também que é impossível e estéril ensinar os conceitos de uma forma direta. Um professor que tenta conseguir isto habitualmente não consegue da criança mais do que um verbalismo oco, um psitacismo que simula um conhecimento dos conceitos correspondentes, mas que na realidade só encobre um vácuo (VIGOTSKI, 2001, p.84).

O percurso da formação de conceitos no ser humano, segundo o psicólogo russo, só se completa na adolescência. Kfouri-Kaneoya (2008) relata que "parece valioso para compreendermos a formulação das crenças que, em um caminho semelhante, também são geradas frente à necessidade essencial de se resolver problemas (p. 80)". Dessa forma, "para explicar as formas mais elevadas do comportamento humano, temos que pôr a nu os meios através dos quais o homem aprende a organizar e dirigir o seu comportamento" (VIGOTSKI, 2001, p.59). Assim sendo,

Todas as funções psíquicas de grau mais elevado são processos mediados e os signos são os meios fundamentais utilizados para os dominar e orientar. $\mathrm{O}$ signo mediador é incorporado na sua estrutura como parte indispensável a bem dizer fulcral do processo total. Na gênese do conceito, esse signo é a palavra, que a princípio desempenha o papel de meio de formação de um conceito, transformando-se mais tarde em símbolo (VIGOTSKI, 2001, p.59).

Nesse processo tem fundamental importância a mediação. $\mathrm{Na}$ perspectiva sociocultural, o ensino é concebido como mediação dialógica, já que, conforme destacou Johnson (2009), quando o ensino cria oportunidades de aprendizagem em que os indivíduos podem participar em atividades que lhes proporcionam experiências diretas no uso de novas 
ferramentas psicológicas, essas ferramentas têm o potencial para funcionar como instrumentos poderosos para o aprendizado humano.

O conceito vigotskiano de mediação está diretamente relacionado à questão da internalização que, não é simplesmente a apropriação direta de conceitos, conhecimentos, ou habilidades de fora para dentro. Se compreendermos a aprendizagem dos professores por meio da perspectiva sociocultural, estaremos diante de um movimento progressivo do exterior para o interior, por meio de atividades sociais de mediação para internalização. Isto implica num processo por meio do qual a atividade de uma pessoa é inicialmente mediada por outras pessoas ou artefatos culturais, mas mais tarde vem a ser controlada por ela mesma diante da apropriação e reconstrução de recursos para regular suas próprias atividades (JOHNSON, 2009, p. 17-18).

Podemos traçar o desenvolvimento cognitivo do professor examinando como a mediação se desenvolve capturada pelo conceito vigotskiano da zona de desenvolvimento proximal (ZDP):

Ela é a distância entre o nível de desenvolvimento real, que se costuma determinar através da solução independente de problemas, e o nível de desenvolvimento potencial, determinado através da solução de problemas sob a orientação de um adulto ou em colaboração com companheiros mais capazes. (...) A zona de desenvolvimento proximal define aquelas funções que ainda não amadureceram, mas que estão em processo de maturação, funções que amadurecerão, mas que estão presentemente em estado embrionário. Essas funções poderiam ser chamadas de "brotos" ou "flores" do desenvolvimento, ao invés de "frutos" do desenvolvimento. O nível de desenvolvimento real caracteriza o desenvolvimento mental retrospectivamente, enquanto a zona de desenvolvimento proximal caracteriza o desenvolvimento mental prospectivamente (VIGOTSKI, 2007, p. 97-98).

Dito de outra maneira, a ZPD pode ser definida como a diferença entre o que uma pessoa pode alcançar de forma independente e o que ela pode conseguir trabalhar em colaboração com os outros ou com um mediador mais capaz. Jonhson (2009) argumenta que ao reconhecermos a ZPD como

multidimensional e dinâmica e como lugar de crescimento potencial, devemos oferecer aos alunos instrumentos de mediação estratégicos, em vez de instrumentos fixos ou aleatórios. Isto, entretanto, é difícil de ser executado nas escolas onde os instrumentos de mediação disponibilizados para os professores tendem a ser formalizados (livros didáticos), fixos 
(técnicas educacionais específicas), e rotinizadas (normas escolares) ${ }^{28}$ (p. 20).

Em outras palavras, a ZDP tem sido descrita como "uma metáfora para observar e entender como instrumentos de mediação são apropriados e internalizados ${ }^{29 "}$ (LANTOLF, 2000, p. 17). Uma vez que apresentamos as crenças como um dos elementos que constituem os conceitos cotidianos, no próximo item nos dedicaremos à reflexão a respeito da formação de conceitos na formação do professor de língua estrangeira.

\subsection{Formação de conceitos no contexto do desenvolvimento do professor de língua estrangeira}

Vieira-Abrahão (2012) argumenta que "os professores chegam aos cursos de formação com noções não articuladas ou sistematizadas sobre linguagem, sobre como ela é aprendida e pode ser ensinada" (p. 462); segundo a pesquisadora, essas noções podem ser aproximadas ao que Vigotski (2001) define como conceitos cotidianos.

Nesta mesma linha, Johnson (2009, p. 14) destaca que, do ponto de vista sociocultural, o desenvolvimento profissional dos professores de línguas torna-se um processo de construção a partir de conceitos cotidianos a respeito da linguagem, do ensino-aprendizagem de línguas, para capacitá-los a compreender os conceitos científicos acerca dessas questões que são produzidos e aceitos na profissão.

As experiências práticas, nesta concepção, estariam relacionadas aos conceitos cotidianos (experiential knowledge) e a teoria se relacionaria aos conceitos científicos (expert knowledge) e no processo de formação profissional ao longo da vida, os professores precisam relacionar os conceitos "especializados" com suas vivências "experienciais", num processo contínuo de reformulação, descrição e interpretação da experiência vivida.

A aprendizagem do professor não depende simplesmente da internalização direta do conhecimento especializado de fora para dentro. Em contraposição, os professores elaboram seus conhecimentos especializados a partir de suas vivências, necessidades, intenções, em

\footnotetext{
${ }^{28}$ No original: "multidimensional, dynamic, and the site of potencial growth, it follows that the kinds of mediational means that are offered to learners must be strategic rather than fixed or random. And this is difficult to do in schools where the mediational means that are offered to teachers tend to be formalized (textbooks), fixed (particular instructional techniques), and routinized (norms of schooling)".

${ }^{29}$ No original: "a metaphor for observing and understanding how mediational means are appropriated and internalized".
} 
suas próprias vozes, e criam sentido contextualmente situados a partir do engajamento em tarefas e instruções significativas para os seus próprios objetivos (JOHNSON, 2009, p. 15). Neste sentido, a autora argumenta que os professores não são receptores passivos de teoria, mas usuários ativos e produtores de teoria por seus próprios meios, e conforme a apropriaçao para seus próprios contextos educacionais.

As atividades que promovemos com os participantes da pesquisa bucaram atender as recomendações de Johnson (2009), ela destaca que os formadores de professores devem buscar examinar as ferramentas e espaços de mediação e, ao mesmo tempo, criar alternativas por meio das quais os professores possam exteriorizar seus entendimentos atuais de conceitos e então re-conceituar e recontextualizá-los e desenvolver formas alternativas de se engajar nas atividades associadas com os conceitos.

As ferramentas e os espaços que estão situadas nessas experiências habilitam professores para trazer à superfície os conceitos espontâneos que moldam a sua consciência e assumir e se apropriar dos conceitos científicos que compõem os conhecimentos que constitui a profissão ${ }^{30}$ (JOHNSON, 2009, p. 16 - destaques nossos).

Oportunidades como as que foram proporcionadas aos nossos participantes destacam a forma como novos entendimentos podem auxiliar os envolvidos a reorganizar seus conhecimentos experienciais e essa recomposição tem potencial para possibilitar novas lentes por meio das quais eles poderão interpretar o entendimento de si mesmos e de suas práticas como alunos e como futuros professores. O saber dos professores tem uma grande quantidade de conhecimento experiencial que pode ser transformado por meio do conhecimento teórico. Jonhson (2009) argumenta que o desenvolvimento cognitivo implica um processo dialógico de transformação de si próprio e da atividade na qual se está engajado e não simplesmente a substituição de habilidades.

Dessa forma, o agenciamento humano desempenha um papel fundamental no processo, já que pode determinar o que é internalizado e como será o processo de internalização de novas compreensões e novas maneiras de engajar-se em atividades. Nesta perspectiva, o desenvolvimento cognitivo do professor está diretamente relacionado à sua Zona de Desenvolvimento Proximal (ZPD), que deve ser compreendida como uma arena de potencialidades, um espaço metafórico do qual a cognição individual se origina na mente

\footnotetext{
${ }^{30}$ No original: "The tools and spaces that are situated in these experiences enable teachers to bring to the surface the spontaneous concepts that shape their consciousness and take up and appropriate the scientific concepts that make up the disciplinary and pedagogical knowledge that constitutes the profession".
} 
social coletiva e emerge por meio do engajamento em atividades sociais (LANTOLF \& THORNE, 2006, p. 263).

\subsection{Considerações}

A compreensão do termo "crenças" no contexto do complexo processo de ensinoaprendizagem de línguas foi o fio condutor do trajeto que traçamos neste capítulo. Evidenciamos ser ampla a terminologia adotada nesta área, fato que coloca em destaque a importância desses estudos.

Destacamos a contribuição da perspectiva sociocultural para a compreensão da formação de professores de línguas e interpretamos as crenças como um elemento da cognição.

Não tivemos como objetivo, neste capítulo, esgotar os conceitos das teorias que comungamos, mas apresentar aqueles mais adequados para o escopo desta tese, conforme sintetizamos no quadro 9:

\begin{tabular}{|c|c|}
\hline Termo & Definição \\
\hline Crença & $\begin{array}{l}\text { "Uma forma de pensamento, como construções da realidade, } \\
\text { maneiras de ver e perceber o mundo e seus fenômenos, co- } \\
\text { construídas em nossas experiências e resultantes de um processo de } \\
\text { interpretação e (re)significação. Como tal, crenças são sociais (mas } \\
\text { também individuais), dinâmicas, contextuais e paradoxais" } \\
\text { (BARCELOS, 2006, p.18). }\end{array}$ \\
\hline $\begin{array}{c}\text { Cognição de professores } \\
\text { de línguas }\end{array}$ & $\begin{array}{l}\text { "Um termo inclusivo, que se refere às redes de conhecimento, } \\
\text { pensamentos e crenças construídas por professores de línguas ao } \\
\text { longo de seu trabalho, sendo tais redes complexas, orientadas pela } \\
\text { prática, pessoais e sensíveis ao contexto, seja qual for o estágio } \\
\text { profissional em que o professor se encontre, ou o contexto de ensino } \\
\text { de línguas no qual atue, pense e desenvolva conhecimentos ou } \\
\text { crenças sobre qualquer aspecto de seu trabalho" (BORG, 2006, p. } \\
\text { 272). }\end{array}$ \\
\hline Conceitos & $\begin{array}{l}\text { "Construções culturais, internalizadas pelos indivíduos ao longo de } \\
\text { seu processo de desenvolvimento. Os atributos necessários e } \\
\text { suficientes para definir um conceito são estabelecidos por } \\
\text { características dos elementos encontrados no mundo real, } \\
\text { selecionados como relevantes pelos diversos grupos culturais. É o } \\
\text { grupo cultural onde o indivíduo se desenvolve que vai lhe fornecer, } \\
\text { pois, o universo de significados que ordena o real em categorias } \\
\text { (conceitos), nomeadas por palavras da língua deste grupo" } \\
\text { (OLIVEIRA, 1992, p. 28). }\end{array}$ \\
\hline
\end{tabular}




\begin{tabular}{|c|c|}
\hline $\begin{array}{c}\text { Zona de } \\
\text { Desenvolvimento } \\
\text { Proximal (ZPD) }\end{array}$ & $\begin{array}{l}\text { "Ela é a distância entre o nível de desenvolvimento real, que se } \\
\text { costuma determinar através da solução independente de problemas, e } \\
\text { o nível de desenvolvimento potencial, determinado através da } \\
\text { solução de problemas sob a orientação de um adulto ou em } \\
\text { colaboração com companheiros mais capazes. (...) A zona de } \\
\text { desenvolvimento proximal define aquelas funções que ainda não } \\
\text { amadureceram, mas que estão em processo de maturação, funções } \\
\text { que amadurecerão, mas que estão presentemente em estado } \\
\text { embrionário. Essas funções poderiam ser chamadas de "brotos" ou } \\
\text { "flores" do desenvolvimento, ao invés de "frutos" do } \\
\text { desenvolvimento. O nível de desenvolvimento real caracteriza o } \\
\text { desenvolvimento mental retrospectivamente, enquanto a zona de } \\
\text { desenvolvimento proximal caracteriza o desenvolvimento mental } \\
\text { prospectivamente" (VIGOTSKI, 2007, p. 97-98). }\end{array}$ \\
\hline Mediação & $\begin{array}{l}\text { "Pode ser caracterizada como um processo de intervenção de um } \\
\text { elemento intermediário numa relação que deixa de ser direta e passa } \\
\text { a ser mediada por tal elemento" (GEHLEN \& DELIZOICOV, 2012, } \\
\text { p. 61). } \\
\text { "É considerada o conceito central da teoria sociocultural. É o } \\
\text { processo por meio do qual os seres humanos se utilizam de artefatos } \\
\text { culturalmente construídos, de conceitos e de atividades para regular } \\
\text { (ganhar controle voluntário e transformar) o mundo material ou seu } \\
\text { próprio mundo e suas atividades sociais e mentais reciprocamente" } \\
\text { (VIEIRA-ABRAHÃO, 2012, p. 5). }\end{array}$ \\
\hline Internalização & $\begin{array}{l}\text { "A internalização das atividades socialmente enraizadas e } \\
\text { historicamente desenvolvidas constitui o aspecto característico da } \\
\text { psicologia humana; é a base do salto qualitativo da psicologia animal } \\
\text { para a psicologia humana" (VIGOTSKI, 2007, p. 76). } \\
\text { "A internalização é definida como o processo por meio do qual a } \\
\text { atividade de um indivíduo é inicialmente mediada por outrem ou por } \\
\text { artefatos culturais, porém mais tarde vem ser controlado por ele, à } \\
\text { medida que se apropria e reconstrói recursos para regular sua própria } \\
\text { atividade" (JOHNSON, 2009). }\end{array}$ \\
\hline
\end{tabular}

Quadro 9: Síntese dos principais conceitos.

A teoria a respeito da formação de conceitos e da relação entre pensamento e linguagem discutida na teoria vigotskiana vem contribuir com a nossa proposta investigativa e, neste contexto, cooperam a noção de zona de desenvolvimento proximal e o papel da mediação e da internalização, questões fundamentais para compreendermos o

\footnotetext{
${ }^{31}$ No original: “internalization. This means the process through which a person's activity is initially mediated by other people or cultural artifacts but later comes to be controlled by him/herself as he or she appropriates and reconstructs resources to regulate his or her own activities".
} 
desenvolvimento dos alunos (professores em formação inicial) participantes da nossa investigação.

No próximo capítulo, o contexto da integração latino-americana será a base para pensarmos no Espanhol-Língua Estrangeira como idioma multidimensional e intercultural para brasileiros. 
CAPÍTULO 3

ESPANHOL-LÍNGUA ESTRANGEIRA MULTIDIMENSIONAL E INTERCULTURAL PARA BRASILEIROS NO CONTEXTO DA INTEGRAÇÃO LATINO-AMERICANA 
Como siempre, la pluralidad marca la diferencia. Lo esencialmente ideológico. El reaseguro de la alteridad. Del saber a los saberes. Del poder a los poderes. Del yo al nosotros. De lo uno a lo múltiple. De la realidad a las realidades. De la cultura a las culturas. De la globalización a los mundos posibles. De la lengua a laS lenguaS.

(I Congreso de laS lenguaS, por una América pluricultural y multilingüe Argentina, 2004) 
Neste capítulo, temos como objetivo contemplar o espanhol como língua multidimensional e intercultural. Não pretendemos esgotar o tema, haja vista que estamos diante de uma questão complexa e que já foi bem explorada em diversos estudos teóricos e em compêndios de sociolinguística. Apenas contextualizaremos o leitor na temática da unidade e diversidade linguística, já que esta investigação busca, dentre outras coisas, averiguar, em um contexto empírico de formação de professores, como os participantes percebem a questão.

Nossa escolha pela análise das possíveis contribuições do cinema como mediador do processo de ensino-aprendizagem de línguas pelo viés do contexto da integração latinoamericana deu-se pela necessidade de despertar via ensino uma consciência de América Latina, já que não bastam só as alianças comerciais, temos que ir além, de forma a promover uma integração que considere a América Latina como uma construção cultural, histórica, política e não somente uma construção geográfica.

Neste sentido, sabemos que promover a integração latino-americana no âmbito linguístico-cultural implica a difusão de uma visão do espanhol como língua multidimensional e intercultural e isso depende da composição de propostas curriculares, da elaboração de materiais didáticos, do ensino propriamente dito, com vista à formação de profissionais que atuem como mediadores culturais preocupados com as diferenças culturais vividas pelos diversos países onde este idioma é falado e tendo em conta a necessidade de promover a interculturalidade e alteridade entre os povos latino-americanos.

Neste contexto, compartilhamos da definição de alteridade proposta pela filosofia, no sentido de ser outro, colocar-se ou constituir-se como outro. Em outras palavras, reconhecerse no outro, integrar-se de forma a ir além das diferenças. Questão essencial no ensinoaprendizado de línguas: "trata-se do desafio de respeitar as diferenças e de integrá-las em uma unidade que não as anule, mas que ative o potencial criativo e vital da conexão entre diferentes agentes e entre seus respectivos contextos" (FLEURI, 2005, p. 95).

Esta tese tem como proposta colaborar com a formação do aluno (professor em formação) como um mediador intercultural sensível às discursividades veiculadas pela linguagem, via texto fílmico, tomando, portanto, o diálogo intercultural como um ponto nevrálgico da formação do professor de E-LE. 
Serrani (2005, p. 18) relata que o perfil de interculturalista, sensível aos processos discursivos, requer que o profissional considere especialmente, em sua prática, os processos de produção-compreensão dos discursos relacionados diretamente à identidade sociocultural.

Exaltamos as potencialidades da sétima arte, como possibilidade para apresentar ao estudante brasileiro a língua espanhola na modalidade oral, em situações verossímeis de comunicação, e nos mais variados lugares do mundo, para com isso, facilitar a aquisição da língua numa perspectiva intercultural, de forma a promover a intercomunicação entre as culturas, investindo, por um lado numa postura de respeito às diferenças e, por outro, na manifestação da alteridade, de forma a permitir ao falante analisar outras culturas desde os padrões culturais delas.

A prática cineclubista e o trabalho em geral com o cinema em ambiente acadêmico nos possibilita promover o reconhecimento das diferenças e o contato com o outro - sem o qual, não existe ética possível - e com as ideias que circulam além de nossos limites geográficos. Entendemos, ainda, que o contato com diferentes manifestações artísticas não só auxilia o estudo das línguas e literaturas, como contribui para aguçar a capacidade de reflexão e ampliar o arcabouço cultural de nossos alunos e da comunidade que fazemos parte.

Assim sendo, as atividades que promovemos, principalmente via cineclube, visam utilizar o cinema para o (re)conhecimento crítico da diferença; encorajar a reflexão e o debate, desconstruir estereótipos negativos e, sobretudo, estimular momentos que fomentem a interculturalidade necessária para a integração latino-americana.

\subsection{Consciência de América Latina}

Convivemos com um suposto discurso de integração latino-americana, que há muito tempo permeia nossos textos oficiais, ao lado de claras evidências de imperialismo e colonização linguística que convertem essas leis em letras mortas.

A Constituição de 1988, no seu artigo 4, parágrafo único, apresenta: “A República Federativa do Brasil buscará a integração econômica, política, social e cultural dos povos da América Latina, visando à formação de uma comunidade latino-americana de nações". Porém, nossa história foi marcada por um percurso que confirma a falta de compromisso com uma política que, de fato, tenha se dedicado à construção de uma relação dialética entre o Brasil e os países hispânicos. Desde o tratado de Tordesilhas, nós e nossos vizinhos hispano- 
americanos vivemos de costas uns para os outros. Nossos olhares estiveram por muitos anos voltados à Europa, representada pelos modelos culturais de Paris e/ou Londres e, anos mais tarde, voltamos nossa atenção para a América do Norte.

Presenciamos, em 1991, a assinatura do Tratado de Assunção, instrumento jurídico fundamental do Mercosul, que deixa bem claro em seu $8^{\circ}$ artigo, tratar-se de interesses comerciais, ou seja: a constituição de um mercado comum entre os países membros: "Da mesma forma como acontece com o Tratado de Roma (25 de Março de 1957) que institui a criação da atual União Europeia, o Tratado de Assunção não tem objetivos culturais e linguísticos propostos ${ }^{32 "}$ (CHAREILLE , 2003, p.66).

Vargas Llosa (2006) questiona “o que significa se sentir um latino-americano?”, e apresenta como resposta: em primeiro lugar, ter consciência de que as demarcações territoriais que dividem nossos países são artificiais, impostas de maneira arbitrária na época colonial e que os líderes da emancipação e os governos republicanos, em vez de repararem, legitimaram e às vezes agravaram, dividindo e isolando as sociedades cujo denominador comum era muito mais profundo que as diferenças particulares.

O intelectual, em seu Dicionário Amoroso da América Latina, tomou a liberdade de redesenhar terras que, nos mapas convencionais, parecem destacadas umas da outras. O peruano cita que não se pode entender a América Latina sem sair dela e observá-la com os olhos, e também, os mitos e os estereótipos que têm sido elaborados acerca dela no estrangeiro.

Segundo o escritor, somente no campo da cultura $^{33}$ a integração latino-americana se aproximou de ser real, imposta pela experiência e pela necessidade. No âmbito político e econômico, os organismos para integrar a região não funcionaram bem, devido aos reflexos nacionalistas enraizados em todo o continente.

As fronteiras nacionais não refletem as verdadeiras diferenças que existem na América Latina. Estas se dão no seio de cada nação de maneira transversal, englobando regiões e grupos de países.

Há uma América Latina ocidentalizada, que fala espanhol, português e inglês e é católica, protestante, ateia ou agnóstica, e uma América Latina indígena, que reúne milhões de pessoas, e que conserva instituições, práticas

\footnotetext{
${ }^{32}$ No original: "de igual forma, tal como ocurre con el Tratado de Roma (25 de marzo de 1957) que instituye la creación de la actual Unión Europea, el Tratado de Asunción no se propone objetivos culturales y lingüísticos".

${ }^{33}$ Relacionamos, como possíveis exemplos o PROLAM (Programa de Pós-Graduação em Integração da América Latina) da Universidade de São Paulo, a UNILA (Universidade Federal da Integração Latino-americana) e o Congreso de laS lenguaS, que alcançou, em 2010, sua terceira edição.
} 
e crenças de raiz pré-colombiana. A América indígena, contudo, não é homogênea: na verdade, é outro arquipélago e passa por diferentes níveis de modernização. Enquanto algumas línguas e tradições são patrimônios de vastos conglomerados sociais, como o quíchua e o aimará, outras, como é o caso das culturas amazônicas, sobrevivem em comunidades pequenas, às vezes com poucas famílias (VARGAS LLOSA, 2006, p.8).

Em seu discurso, o autor reforça a ideia de uma América Latina com traços marcantes de mestiçagem. A diversidade multicultural faz dela um protótipo do mundo. A busca pela definição de uma identidade latino-americana tem sido recorrente em nossa cultura,

Da mesma forma como em outras partes do mundo, essa mania de determinar a especificidade histórico-social ou metafísica de um conjunto gregário já fez correr oceanos de tinta na América Latina e gerou ferozes discussões e intermináveis polêmicas (VARGAS LLOSA, 2006, p.9).

Assim sendo, acreditamos que definir a identidade latino-americana é uma pretensão tão inútil quanto impossível, o que nos parece latente é a necessidade de despertar uma consciência comum de "América Latina" e, neste sentido, o linguístico é fundamental para a integração regional.

Arnoux (2010) analisa as representações sociolinguísticas e a construção de identidades coletivas. Esta pesquisadora apresenta que o povo latino-americano terá que ampliar suas identidades nacionais rumo a uma identidade que implica a consciência de um destino comum.

A construção de uma identidade coletiva impõe a necessidade de políticas linguísticas plurilíngues sustentadas em políticas midiáticas e escolares que permitam aos futuros cidadãos compreenderem uns aos outros, para que possam expressar-se em outras línguas e ser capazes de elaborar estratégias de aprendizagem dessas línguas.

Neste sentido, é desejável que as políticas linguístico-culturais contemplem várias modalidades de bilinguismo português-espanhol e a convivência com as línguas dos povos originários. A aprendizagem da língua do outro cumpre uma função decisiva não só porque permite ampliar as redes comunicativas, mas também pelo jogo de ressonâncias culturais as quais cada língua está associada.

É preciso também respeitar as línguas indígenas, que na maioria dos casos unem aldeias de cada lado da fronteira, porque restabelecem vínculos que vão erodindo os velhos limites nacionais que os Estados construíram. Daí a necessidade de atribuir uma importância especial a línguas de ampla expansão como o guarani e o quíchua. $\mathrm{O}$ quíchua une todos os países da região andina, enquanto o guarani é a língua que domina a bacia do Prata e é, além disso, co-oficial do Paraguai. Em nosso caso, ademais, o mapuche enlaça, ao sul, o Chile e a Argentina. Ir construindo uma trama tal que o 
espanhol-português se acompanhe deste fortalecimento das línguas indígenas, e que o seu conhecimento seja transmitido, também com diferentes modalidades, à população não indígena ${ }^{34}$ (ARNOUX, 2012, p.1).

Tanto a legislação brasileira (Lei $\mathrm{n}^{\circ}{ }^{11.161 / 2005)}$ ) quanto a $\operatorname{argentina~(Lei~n.~}{ }^{\mathrm{o}}$ 24.468/2009), podem ser consideradas como exemplos de respostas às necessidades atuais de integração regional. Porém, para que medidas como essas não fracassem, faz-se necessária a conscientização e a atuação da população de forma que essas políticas sejam implantadas e se tornem, de fato, públicas. Neste ensejo, é importante avaliar as crenças associadas às línguas.

Diante do exposto, a integração regional pode ir além da pauta meramente econômica e, para consolidar a integração político-cultural, é fundamental a integração linguística, que implica a sensibilização da população para que adquira consciência da importância da integração regional para o futuro dos nossos países.

A sensibilização para a necessidade de integração, na maioria das vezes, não ocorre. Exemplos disso são as leis de implantação do espanhol no Brasil e do português na Argentina que acabamos de mencionar, cuja implantação caminha a passos muito lentos.

Dito de outra maneira, como aluno, professor, pesquisador e formador de professores no Cariri paraibano temos lutado para que ocorra, no Brasil e, consequentemente, em nosso

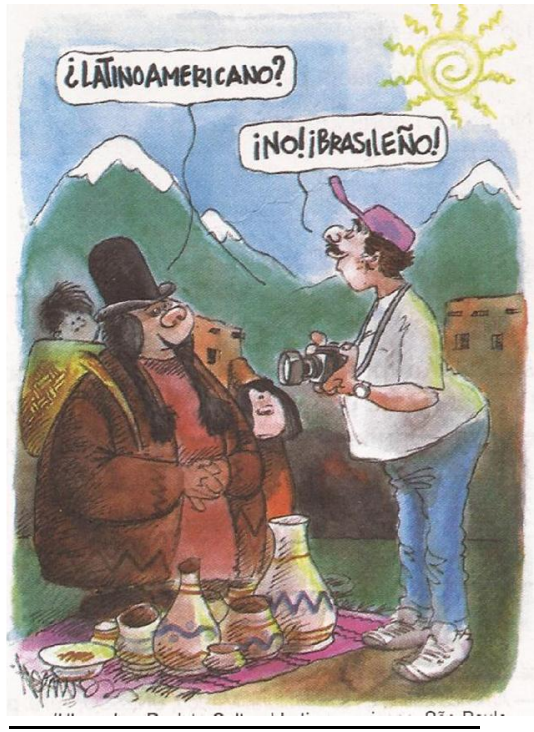
Estado, mudanças quanto ao ensino das línguas estrangeiras, principalmente para que haja políticas públicas de divulgação, implantação e reconhecimento da importância do ensino do espanhol em nosso território de forma que a Lei n. ${ }^{\circ} 11.161 / 2005$ deixe de ser letra morta e promova a língua viva no contexto da integração latinoImagem 6: Charge publicada em Hispania - Revista Cultural Latinoamericana. São Paulo, americana. Hispania Editora, Año I, n. 1, mayo/jun. 1996, apud BRUNO \& MENDOZA, 2001, p 15.

Neste sentido, sabemos que ainda há muito para ser feito no

\footnotetext{
${ }^{34}$ No original: "Hay que atender también a las lenguas indígenas, que en la mayoría de los casos unen pueblos de un lado y otro de la frontera, porque restablecen vínculos que van erosionando los viejos límites nacionales que los Estados construyeron. De ahí la necesidad de asignarles una importancia particular a lenguas de amplia expansión como el guaraní y el quechua. El quechua une a todos los países de la zona andina, mientras que el guaraní es la lengua que domina la cuenca del Plata y es, además, cooficial en Paraguay. En nuestro caso, además, el mapuche enlaza, por el Sur, Chile y la Argentina. Ir construyendo un entramado tal que el españolportugués se acompañe de este fortalecimiento de las lenguas indígenas, y que su conocimiento sea transmitido, también con diferentes modalidades, a la población no indígena".
} 
campo da formação inicial e continuada de professores. Em decorrência desse quadro, há a necessidade de preparar material didático não somente para tê-lo como material de apoio, mas também para direcionar um estudo preocupado com as diferenças culturais experimentadas pelos diversos países em que esta língua é falada.

A questão da implantação da lei 11.161/2005 foi discutida em nossa dissertação de mestrado (SOUZA, 2009). Naquela ocasião, já sinalizávamos que o Estado utilizava-se da ausência de ações como estratégia política para a não apropriação da lei, bem como a falta de interesse na promoção de um espanhol que promovesse a integração latino-americana.

Para reforçar a ideia de integração, é necessário o maior envolvimento dos falantes, do estado, da mídia e da indústria cultural. Os meios de comunicação poderiam, como representantes do $4 .^{\circ}$ poder, cumprir um papel fundamental neste processo. Arnoux (2012) relata, por exemplo, que a TELESUR é uma emissora que divulga conhecimentos relacionados a vários países da América Latina, porém, não tem ampla difusão. Relata também que antes da expansão de temas como MERCOSUL, UNASUL e das políticas acadêmico-culturais de integração era possível, via empresas de TV a cabo, assistir -na Argentina- a vários programas da TV brasileira, o que hoje já não é mais possível.

Por exemplo, Telesul, que possibilita o conhecimento dos outros países sulamericanos, não tem ampla difusão. É incrível, por outro lado, que algumas empresas de TV a cabo não sejam acessíveis à televisão brasileira, quando antes sim podíamos fazê-lo. Este é um tema de política regional, que tem de ser tratado na Unasul, tampouco pode ser que no Brasil a gente se informe, em espanhol, pela CNN, do que está acontecendo no mundo. A mídia deve fazer um esforço e os governos devem implementar políticas para que essas emissões que permitem o conhecimento dos outros países latino-americanos cheguem a todos. A língua e a cultura têm uma importância decisiva para que nos conheçamos. E, nesse sentido, não devemos esquecer a necessidade de implementar políticas conjuntas entre os países hispano-americanos, tanto para elaborar instrumentos linguísticos quanto para preparar materiais para a divulgação do espanhol e, inclusive, propor certificados de domínio das línguas comuns ${ }^{35}$ (ARNOUX, 2012, p. 4).

\footnotetext{
${ }^{35}$ No original: "Por ejemplo, Telesur, que posibilita el conocimiento de los otros países sudamericanos, no tiene amplia difusión. Es increíble, por otro lado, que en algunas compañías de cable no se pueda acceder a la televisión brasileña, cuando antes sí podíamos hacerlo. Ese es un tema de política regional que tiene que ser tratado en la Unasur; tampoco puede ser que en Brasil uno se entere, en español, por la CNN de lo que está pasando en el mundo. Los medios deben hacer un esfuerzo y los gobiernos deben implementar políticas para que esas emisiones que permiten el conocimiento del otro latinoamericano lleguen a todos. La lengua y la cultura tienen una indudable importancia en ese conocernos. Y en ese sentido, no hay que olvidar la necesidad de implementar políticas conjuntas entre los países hispanoamericanos, tanto para elaborar instrumentos lingüísticos como para preparar materiales para la difusión del español e, incluso, proponer certificados de dominio de la lengua comunes".
} 
No Brasil, o contato com a língua e cultura espanhola, via TV a cabo, só é possível na maior parte das vezes - via TVE ou pela CNN em Espanhol. Os meios de comunicação são fundamentais neste processo de integração e poderiam promover conteúdo que permita o conhecimento do outro latino-americano. Neste sentido, é fundamental e urgente que os governos implementem políticas públicas para que as transmissões que permitam a intercompreensão latino-americana cheguem a todos.

\subsection{Variação e preconceito}

A problemática da variação na língua espanhola, quando abordada desde uma perspectiva brasileira, implica o predomínio, muitas vezes, de noções cristalizadas de "certo" e "errado" que perpetuam o preconceito linguístico que geram a dicotomia "espanhol da Espanha" vs "Espanhol da América", além do imaginário de um centro legislativo da língua, o controle in vitro ${ }^{36}$ exercido pela Real Academia ou até mesmo a crença em um espanhol "neutro" ou "internacional", que muitas vezes geram equívocos no ensino dessa língua estrangeira no Brasil.

Roberto Bein, da Universidad de Buenos Aires, ao analisar as políticas linguísticas do Mercosul, apresenta um exemplo das consequências dessa ênfase ao espanhol peninsular, bem como da falta de uma política linguística latino-americana.

O professor transcreve um e-mail recebido de uma prima argentina que vive no Rio de Janeiro e relata como estão sendo as aulas de espanhol que o filho dela tem na escola brasileira: "a professora descontou um ponto na prova do Miguel, pelo fato de, ao escrever o abecedário em espanhol, ter colocado ' $v e^{\prime}$ pela $\mathrm{V}$ e 'doble $v e^{\prime}$ pela $\mathrm{W}$, e a professora insiste em dizer que é incorreto, que a única opção é 'uve' e 'uve doble'”, (BEIN, 2008).

$\mathrm{O}$ exemplo citado demonstra claramente a questão das atitudes em relação às línguas: ao aluno, falante nativo de espanhol e aprendiz dessa língua em um país onde esse idioma é

\footnotetext{
36 Calvet (2002) analisa as mudanças linguísticas a partir da dicotomia "in vivo" e "in vitro". O autor argumenta que a maldição de Babel, defendida por alguns, nunca impediu a intercomunicação de sociedades em convívio já que as línguas em contato mudam de forma natural, em função das práticas sociais, gestão "in vivo" de uma situação linguística como consequência dos modos como as pessoas resolvem os problemas de comunicação com que se confrontam diariamente. A gestão "in vitro" refere-se à transformação pela intervenção do poder e pelo planejamento linguístico por meio legislativo, forma artificial de alterar determinada situação linguística. Calvet (2007) defende que a política linguística vê-se sempre sujeita a duas forças, buscando a coerência entre os objetivos do poder e as soluções intuitivas que são frequentemente postas em prática pelo povo, bem como do problema de certo controle democrático, a fim de não deixar os "decisores" fazerem o que bem entendam.
} 
ensinado como língua estrangeira, a professora corrige o nome das letras " $\mathrm{V}$ " $\mathrm{e}$ "W" porque o espanhol difundido no Brasil tem privilegiado a norma peninsular. Atitudes como essa são legitimadas pela política linguística do Brasil, da Argentina e da Espanha. Conforme aponta Bein (2008), quando um país não empreende sua própria política linguística interna e externa se vê submetido à política de terceiros países.

Em geral, toda consideração das línguas e variedades como fator de identificação e símbolo de identidade social, grupal, nacional, etc., como marca do "pertencer" a um "nós" coletivo, pode relacionar-se com essa temática [das atitudes lingüísticas], por isso a incorporação do conceito "representação social" (Jodelet, 1989), oriundo das ciências sociais, também interveio no desenvolvimento de alguns estudos sobre atitudes (FANJUL, 2004, p. 169).

Ainda hoje sofremos as consequências das relações entre discurso colonial e discurso linguístico (CALVET, 2005) e, independente da variante de espanhol adotada em nosso território, temos que encarar o fato de que aqui se desenvolverá um "Espanhol brasileiro". Nesse aspecto, compartilhamos da reflexão tecida por Celada e Rodrigues (2005, p. 9), quando as pesquisadoras afirmam ser preciso reconhecer que a língua espanhola em expansão por terras brasileiras deverá submeter-se a certa heterogeneidade, deixando-se filtrar, sem pruridos puristas, por novas formas de dizer que resultam da maneira como um brasileiro explora sua posição específica de estrangeiro e no espanhol se inscreve.

Para Revuz (1998), aprender uma língua é sempre, um pouco, tornar-se outro. O que se estilhaça ao contato com a língua estrangeira é a ilusão de que existe um ponto de vista único sobre as coisas, é a ilusão de uma possível tradução termo a termo, de uma adequação da palavra à coisa.

Antes de falar todo sujeito está imerso em, um mundo de discursos, no qual há sempre interpretações (explícitas, implícitas ou denegadas) sobre o sujeito e seu sentir, sobre expectativas a seu respeito e sobre o mundo ao seu redor. As memórias discursivas são aquilo que está inscrito no sujeito juntamente com/nas palavras da língua materna. E é isso que o encontro com novas línguas, novas variedades, discursividades e culturas questionará, perturbará, mobilizará (SERRANI, 2005, p. 19).

Sobre a interferência da língua materna na constituição deste "novo eu" em contato com a língua espanhola no Brasil, será sempre uma reconstrução baseada na língua ou variedade de origem, aquela que teceu o inconsciente, e nas bases ou memórias discursivas, que constituem a denominada "identidade cultural" de cada um de nós. 
A sociolinguística, no âmbito acadêmico, tem tentado desmistificar conceitos enraizados sobre as línguas naturais ao defender que todas as variantes linguísticas servem com a mesma qualidade ao propósito de comunicação, que seria a principal função das línguas.

Ainda hoje, diversos mitos habitam o imaginário coletivo, como, por exemplo, a ideia de que seria possível ensinar/aprender o espanhol de 'cada país', de forma que o aluno necessitasse consequentemente, aprender a falar 'como espanhol', 'como argentino', 'como mexicano' (FANJUL, 2004, p.165).

Os avanços nos estudos da relação entre língua e sociedade já deixaram claro que a variação é uma característica comum às línguas e, no que concerne ao espanhol, compartilharemos da citação de Valle (2005), para quem a língua espanhola é muitas coisas: "Para alguns nem espanhol é: é castelhano. E o é, em cada caso, por razões bem diferentes. Esta língua é falada em lugares distantes e de maneiras diferentes. Vive em comunidades bem diferentes e em cada uma delas assume valores materiais e simbólicos peculiares ${ }^{37}$ (p. 391)"

Todo falante, como membro de determinada comunidade linguística, estará condicionado por variantes geográficas e sociais, por meio de vínculos de ordem psíquica e coletiva internalizadas independente da sua vontade individual, ou seja, como fruto do "contrato coletivo" ao qual o indivíduo faz "adesão" ao participar de determinado grupo social.

A variação em determinada língua pode ser classificada por critérios geográficos (variação diatópica), sociais (variação diastrática) e de estilo (diafásica) já que a língua varia no tempo e no espaço conforme as características dos usuários e da situação de comunicação. O contexto comunicativo regula e determina de alguma forma as condutas linguísticas e extralinguísticas dos interlocutores.

Os falantes costumam adequar suas realizações linguísticas a determinada cena comunicativa. Dessa forma, o domínio e o emprego adequado de modalidades linguísticas e registros são proporcionais à proficiência dos interlocutores, buscando alcançar o maior nível de domínio de registros. A língua é heterogênea por definição e sempre há múltiplas

\footnotetext{
${ }^{37}$ No original: "La lengua española es muchas cosas. Para algunos ni español es; es castellano. Y lo es, en cada caso, por muy distintas razones. Se habla esta lengua en lugares lejanos y de maneras diferentes. Vive en comunidades muy dispares y en todas ellas asume valores materiales y simbólicos peculiares".
} 
variedades linguísticas (sociais, regionais, registros em diferentes contextos), que se realizam em gêneros discursivos particulares (SERRANI, 2005).

A variação $n a$ e $d a$ língua espanhola pode ser explorada e aprofundada, abordando as principais variantes americanas e peninsulares a partir de mostras autênticas ou verossímeis de língua, segundo os critérios da filologia, dialetologia e sociolinguística. Esse tema é de fundamental importância. Bugel (1998) destaca o professor como um modelo sociolinguístico para o aluno; dessa forma, se o docente não explicitar a questão da unidade e diversidade, o aprendiz poderá considerar as realizações diferentes daquelas do professor como erradas de maneira preconceituosa, fruto de puro desconhecimento.

Os documentos oficiais (PCN, OCEM-Espanhol) propõem o ensino de espanhol de maneira a expor o aluno à alteridade, à diversidade e à heterogeneidade da língua estrangeira. Neste sentido:

É importante ressaltar que o contato que os alunos tenham com as variedades do espanhol não pode ser estabelecido apenas por meio de simples curiosidades léxicas, como se as diferenças fossem reduzidas a umas tantas palavras que se usam em um lugar e em outro não. É necessário que as variedades apareçam contextualizadas e por meio de um falante real ou possível que mostre tal variedade em funcionamento. O professor não pode falar apenas sobre as variedades e ser a única voz que as representa, é importante que transmita a palavra a outros falantes que mostrarão como cada variedade realmente funciona ${ }^{38}$ (VENTURA, 2005, p. 119-120).

A autora, quando indica que o ensino de língua estrangeira deve estar contextualizado na fala do nativo, no ensino da variação linguística, seguramente, não fala de um encontro direto com o livro didático, que certamente trará, tão somente, curiosidades lexicais, distorcendo a ideia do que seja a variação linguística para o aluno. Tendo esse pressuposto, o cinema, enquanto ferramenta didática, cumpre a função educativa determinada pelos seus fins pedagógicos, de propiciar ao alunado amostras contextualizadas e, portanto, carregadas de valor cultural e ideológico da própria língua espanhola.

Em contextos formais de ensino-aprendizagem, o professor de língua estrangeira muitas vezes arrisca-se na tentativa de ser o único porta-voz do Outro, mediante suas falas e cultura, falhando no engajamento para o desenvolvimento do bloco língua-contexto-realidade.

\footnotetext{
${ }^{38}$ No original: "Es importante resaltar que el contacto que los alumnos tengan con las variedades del español no se puede establecer sólo por medio de simples curiosidades léxicas, como si las diferencias se redujeran a unas tantas palabras que se usan en un lugar y en otro no. Es necesario que las variedades aparezcan contextualizadas y por medio de un hablante real o posible que muestre dicha variedad en funcionamiento. El profesor no puede sólo hablar sobre las variedades y ser la única voz que las representa, es importante que transmita la palabra a otros hablantes que mostrarán cómo funciona realmente cada variedad".
} 
O professor como arquiteto da arte de ensinar, tem a capacidade de inventar e reinventar sua prática de ensino, e pode buscar, nos materiais didáticos, meios, e não fins, que lhe possibilite contribuir para a aprendizagem e formação dos alunos.

Nossa proposta em levar o cinema para a sala de aula se apoia no fato de que ele com sua dinamicidade transporta o indivíduo para um meio desconhecido, em que pouco se conhece sobre a cultura do outro, seus costumes e suas crenças. A língua estrangeira é, antes de tudo, um sentir-se estrangeiro e o cinema pode ser mediador deste encontro com o Outro.

O texto fílmico é dinâmico e pode possibilitar a aprendizagem fora dos padrões convencionais de ensino e despertar, no aluno, o interesse em conhecer/entender a ação do outro que vê na tela, e saber o porquê dele agir de determinada maneira e, isso só é possível, conhecendo a cultura, o contexto e a ideologia. Só assim, é que se pode estabelecer uma relação compreensiva com o outro.

Há a necessidade da conscientização de alunos, professores e grupos editoriais a respeito da unidade e diversidade da língua para que se produzam materiais mais coerentes, a partir de diferentes visões da língua espanhola e que sejam respeitadas as diferenças como características inerentes à língua e não como curiosidades do povo conquistado.

Neste sentido, uma problematização necessária é em relação à produção dos materiais didáticos, que reproduzem essa visão parcial, estereotipada e de caricatura da língua e seus falantes. Porém, na maioria das vezes os autores até apresentam propostas interessantes pensadas rumo à diversidade, mas os grupos editoriais barram os projetos por conta dos custos para contratar nativos de diferentes países para fazerem as gravações ou para pagar direitos autorais por textos autênticos e/ou colocam a revisão ou edição nas mãos de uma equipe (na maioria das vezes espanhola) que não está preparada nem aberta a essa visão de unidade diversidade e o projeto acaba se perdendo.

Consequência disso é que a maior parte dos livros didáticos de espanhol existentes no Brasil não apresentam muito a respeito das variantes do espanhol hispano-americano e, quando o fazem, reduzem a variação a puras amostragens sem qualquer reflexão maior a seu respeito.

Em publicação dedicada a compreender a natureza social e educacional dos processos de ensino/aprendizagem de línguas, Moita Lopes (1996) dedicou um capítulo para discutir a atitude de professores e alunos de inglês como língua estrangeira no Brasil em relação às culturas dos falantes nativos, sobretudo os ingleses e norte-americanos. O autor criticou a 
"atitude exageradamente positiva e de quase adoração pela cultura de língua inglesa" (p. 37), questão que pode ser transposta para a área de E-LE no que diz respeito ao prestígio pela variante peninsular em detrimento das variantes hispano-americanas, na maioria das vezes estigmatizadas.

Estudos como o de Bugel (1998) mostram que alguns alunos e professores de E-LE da cidade de São Paulo preferem aprender/ensinar o espanhol peninsular por considerarem uma variante de prestígio. Inclusive, a autora destaca que muitos professores, falantes nativos latino-americanos, por terem o livro didático como uma espécie de "camisa de força", renunciam a suas variantes maternas em prol de uma imaginada língua padrão, sempre ligada à ideia de espanhol da Espanha.

Outro fato merecedor de questionamento é o imaginário coletivo que projeta o espanhol falado na Espanha como padrão. $\mathrm{Na}$ verdade, nem na própria Espanha esta língua é única, padronizada, estandardizada. Estudo realizado por Irala (2004), com professores em serviço e pré-serviço, também mostrou a predominância da preferência pelo espanhol peninsular, fato já destacado no PCN-LE, 1998:

Embora em um nível diferente, devido ao papel que os Estados Unidos representam na economia internacional, a mesma vinculação do inglês com os Estados Unidos é detectada na associação do Espanhol com a Espanha no Brasil. Chamar a atenção por meio de trabalhos de pesquisa para países que usam o espanhol tanto como língua materna e/ou língua oficial nas Américas (Argentina, Bolívia, Chile, El Salvador, Equador, Guatemala, Paraguai, Uruguai etc.) traz para sala de aula aspectos de natureza sociopolítica da aprendizagem de uma língua estrangeira, além de contribuir para uma percepção intercultural da América (p.50-51).

No âmbito dos documentos oficiais, como por exemplo, a Constituição de 1988, os PCN e as OCEM-Espanhol, a diversidade é tratada com ênfase. No entanto, constatamos o fato de o discurso jurídico não ser apropriado pelos agentes que o colocam em prática; dessa forma, a maior parte dos professores, materiais didáticos e, consequentemente, alunos, ignoram a diversidade linguística do espanhol.

A presença dessa língua no Brasil é dividida por Celada (2002) em duas cenas: a primeira iria até o início dos anos 90, e a segunda partiria desse período e alcançaria nossa contemporaneidade, momento em que se instaura outra "nova memória". Lemos (2008, p.12) cita a Lei $\mathrm{n}^{\circ}$ 11.161/05, que torna obrigatória a oferta da língua espanhola nas escolas brasileiras que atuam no ensino médio, como um acontecimento discursivo que coloca em relação a atualidade dessa língua com a memória discursiva. Para a pesquisadora, essa lei 
desata efeitos como a escrita das Orientações Curriculares Nacionais para o Ensino MédioEspanhol (OCEM-Espanhol) que afetam antigas rotinas no que tem a ver com o aprendizado dessa língua em nosso território.

Considerando que "(S/C)em línguas, (S/C)em mundos"39 faz-se necessário levar estes mundos possíveis para a sala de aula de língua estrangeira.

Propomos a busca pela formação de um aprendiz que além da competência comunicativa, tenha insumos que instiguem seu potencial para alcançar o perfil intercultural, pois além de se comunicar adequadamente em contextos interculturais, terá sensibilidade para perceber o impacto que a diferença cultural exerce no processo comunicativo, em outras palavras, compreenderá "os padrões de comunicação, as expectativas e interpretações de outros $^{40,}$ (JIN \& CORTAZZI, 2001, p.124), e assim poderá interagir com seus vizinhos latino-americanos que se encontram tão próximos fisicamente e com tantas barreiras a romper no plano ideológico, econômico, político, dentre outras.

$\mathrm{Na}$ suposta promoção de um espanhol para a integração latino-americana, como preconizam nossos textos oficiais, para garantir o princípio fundamental da linguagem baseado no fenômeno social da interação verbal, como propõe o teórico russo Bakhtin (1999), surge a necessidade elementar de ver o outro, de dar voz aos seus sentimentos.

Cada falante pertence, de forma potencial, a várias comunidades discursivas que os reconhecem como seus, em maior ou menor grau, sendo o aprendiz estrangeiro o que tem maior capacidade para perceber as diferenças. $\mathrm{O}$ que confere ao estudante essa capacidade é o fato de olhar com os olhos de quem vê de fora, sem estar imerso naquela comunidade linguística. Esse potencial só pode acrescentar o repertório daquele que desvenda o novo: o privilégio do falante intercultural tem que estar acompanhado de uma valorização da responsabilidade no uso das palavras e da posse de seus significados (KRAMSCH, 2001).

Nesta tese, compreenderemos cultura como o sistema de crenças, valores, costumes, condutas e artefatos compartilhados, que os membros de uma sociedade usam na interação entre si e com o seu mundo, sendo transmitida de geração em geração por meio do aprendizado. Dessa forma, a cultura é transmitida no processo de socialização e, diante do contato com outras culturas pode ocorrer o etnocentrismo, o relativismo cultural ou o interculturalismo.

\footnotetext{
39 "Sem línguas, Sem possibilidade de mundos ou Cem línguas, Cem mundos possíveis". Este foi o título da XIII Semana de Letras da UNESP - São José do Rio Preto, 2001.

${ }^{40}$ No original: los patrones de comunicación, las expectativas e interpretaciones de otros".
} 
Aguilera Reija et alii (1996) apresentam a visão etnocêntrica caracterizada pela adoção da cultura própria como modelo para avaliação de outras formas de viver e conceber o mundo, procedimento que pode gerar problemas, a partir de uma compreensão desfigurada daquilo que está sendo observado. Já o relativismo cultural é apresentado por uma atitude aberta em face do conhecimento e análise de outras culturas, considerando-as iguais, mas sempre tomando como ponto de partida nossos próprios valores.

Ao mesmo tempo em que representa um posicionamento de respeito e tolerância, o relativismo cultural mantém o isolamento entre diferentes grupos humanos. Dito de outra maneira, o relativismo cultural apresenta uma atitude aberta em face do conhecimento e análise de outras culturas, considerando-as iguais, mas sempre tomando como ponto de partida nossos próprios valores. Ao mesmo tempo em que representa uma postura de respeito e tolerância, o relativismo cultural mantém o isolamento entre diferentes grupos humanos. "Eu te respeito e te compreendo, mais você na sua casa e eu na minha”.

Já o interculturalismo busca a intercomunicação entre as culturas, tentando superar o relativismo cultural e avançar para a conquista de uma atitude de respeito e igualdade que nos permita analisar as outras culturas desde seus próprios padrões culturais.

A ideia de interculturalidade é proposta por alguns pesquisadores a partir da releitura do conceito de competência comunicativa de Del Hymes, bem como de sua visão de etnógrafo. Parte-se da concepção de que desde os nossos primeiros dias de vida buscamos entender o mundo que nos rodeia observando, escutando e, com o tempo, falando. Dessa forma, esse constructo seria uma competência que forma parte das práticas sociais e culturais de uma comunidade, na qual a língua ocupa posição central.

Essa releitura propõe a etnografia como forma de estudar os 'Outros' e, assim sendo, as estruturas sociais e culturais que dão sentido às suas vidas. Serrani (2005) argumenta que o componente sociocultural é sempre posto em relevo na teoria, mas não é raro que tenha um papel secundário em práticas do ensino de línguas.

A autora apresenta a necessidade de o professor de línguas portar-se como interculturalista, referindo-se a um docente apto para realizar práticas de mediação sociocultural, contemplando o tratamento de conflitos identitários e contradições sociais na linguagem da sala de aula.

Dessa forma, ao entendermos que a língua se realiza sempre em discursos ou, como argumentou Bakhtin (1999), em gêneros discursivos, é indispensável que a formação do 
docente de línguas capacite o futuro profissional a propiciar aos seus alunos reacomodações subjetivo-emocionais, cognitivas e sociais inerentes à produção discursiva de sentidos.

A formação de um docente de línguas como interculturalista requer capacitação para que ele não conceba seu objeto de ensino - a língua - como um mero instrumento a ser "dominado" pelo aluno, segundo progressões de complexidade apenas morfossintática ou de apresentação de situações comunicativas (SERRANI, 2005, p 17).

A proposta de Serrani (2005) é norteada por uma política linguística cultural e educativa na qual se levaria em conta: a) estimular os alunos a estabelecerem pontes culturais com outras sociedades e culturas, b) propiciar a educação à diversidade sociocultural e ao questionamento de etnocentrismos e exotismos, c) dar ao componente cultural um peso significativo no planejamento de cursos de línguas. Na concepção da autora, teríamos uma ideia discursiva, portanto processual e sócio histórica, da linguagem, nos componentes de um currículo multidimensional.

[a] proposta é que em cada projeto pedagógico, currículo, programa, planejamento etc. se selecionem, de forma explícita e destacada, materiais lingüístico-discursivos correspondentes a territórios, momentos, grupos sociais e legados culturais que permitam um enfoque culturalmente heterogêneo (SERRANI, 2005, p. 32).

Dessa forma, esse deslocamento conceitual resultante de considerar que a língua só acontece em processos discursivos, e por sua vez, que esses não podem ocorrer sem a materialidade da língua e da história, leva a propor que o componente de conscientização da linguagem não seja um componente separado, mas que seja parte substancial do módulo de língua discurso.

\subsection{O lugar das línguas estrangeiras na legislação}

Diante do nosso contexto de formação de professores, além de pensar a questão da unidade e diversidade experimentada pela língua espanhola do ponto de vista teórico, enfocaremos o que os documentos oficiais brasileiros (PCN, OCEM, PNLD) apresentam em relação à difusão desta língua estrangeira em nosso país. Acreditamos ser fundamental discutir a relevância desse conteúdo nos cursos de formação de professores, pois é ali que o professor começa a dar sentido a esses documentos. O problema é quando o docente lê esses textos e não sabe o que fazer com eles ou não sabe interpretá-los. 
O direito ao pluriculturalismo e ao multilinguismo é garantido pelos artigos 215 e 216 da nossa Lei Magna. Porém, os espaços enunciativos para as línguas estrangeiras dentro da escola pública tinham sido restritos, até a promulgação da Lei 11.161/2005, ao encontro na maioria das vezes frustrado e traumatizante com a língua inglesa. Este encontro, muitas vezes a primeira relação do aprendiz brasileiro com a língua estrangeira na escola, pode acabar determinando a relação desse sujeito com outras línguas estrangeiras ao longo da vida.

A lei 11.161/2005 representa um gesto claro de política linguística, e demanda reflexões sérias a respeito do lugar que o espanhol pode e deve ocupar no processo educativo. Esse acontecimento discursivo vem a romper com a memória de não especificação das línguas estrangeiras na legislação de até então, e o direito (ainda que virtual) ao pluriculturalismo e ao multilinguismo só pode ter espaço depois que a escola cumpra com a oferta obrigatória da língua espanhola.

Ao dispor sobre “o ensino de Língua Espanhola”, a Lei 11.161/2005 apresenta as seguintes especificações de organização curricular:

- oferta obrigatória pela escola no Ensino Médio (art. 1. ${ }^{\circ}$ caput);

- oferta facultada nos anos finais do Ensino Fundamental (art. 1. ${ }^{\circ}, \S 2^{\circ}$ );

- matrícula facultativa para os alunos (art. 1. ${ }^{\circ}$ caput);

- implantação gradativa nos currículos do Ensino Médio a completar-se em cinco (5) anos, ou seja, até 2010 (art. $1 .^{\circ}$ caput e $\S 1 .^{\circ}$ );

- nas escolas públicas, o ensino de Língua Espanhola deve ser feito no horário letivo regular (art. 2. ${ }^{\circ}$ );

- nas escolas privadas, o ensino de Língua Espanhola poderá ser no horário letivo regular ou por meio de outras estratégias (art. 4. ${ }^{\circ}$ ). (grifo nosso).

A questão de a oferta ser obrigatória pela escola no Ensino Médio e a matrícula facultativa para os alunos (art. 1) constitui o tema das maiores polêmicas que a lei tem gerado. Outro ponto problemático é a indeterminação do modo como deverá ser oferecida a disciplina, já que em nenhum momento a lei determina a carga horária semanal e nem a quantidade de anos de oferta do espanhol no ensino médio, por exemplo ${ }^{41}$.

41 Por limitações de espaço, não nos deteremos nestas questões, que podem ser encontradas discutidas criticamente e de forma detalhada em Rodrigues (2010). 
$\mathrm{O}$ art. 5..$^{\circ}$ salienta a competência dos Conselhos Estaduais de Educação e do Distrito Federal para "emitir as normas necessárias" à sua execução, "de acordo com as condições e peculiaridades de cada unidade federada" e conclama a União a estimular e apoiar os sistemas de ensino estaduais e do Distrito Federal, no âmbito da política nacional de educação (art. $6^{\circ}$ ).

Estamos diante de uma lei ordinária, sem fazer referência explicita a outra ordem normativa, pois, ela não altera, qualquer dispositivo da Lei de Diretrizes e Bases da Educação Nacional ou de qualquer outra Lei Federal. O sistema educacional brasileiro, após a aprovação da lei n. ${ }^{\circ}$ 9.394, de 20 de dezembro de 1996, que estabelece as diretrizes e bases da educação nacional apresenta dois níveis escolares: Educação Básica e Educação Superior. A primeira formada pela Educação Infantil, Ensino Fundamental e Ensino Médio. A Educação superior abrange cursos de graduação e pós-graduação (compreendendo programas de mestrado, doutorado, especialização, aperfeiçoamento, entre outros), inclui também cursos sequenciais por campo do saber e cursos de extensão. Há ainda modalidades de educação e ensino: Educação Especial, Profissional e de Jovens e Adultos.

Nesta LDB de 1996 a Língua Estrangeira recupera a importância que durante algum tempo the havia sido negada. Legislando sobre o nível Fundamental e Médio: no primeiro, determina a oferta obrigatória, a partir do sexto ano (nomenclatura nova, do EF de nove anos): “o ensino de pelo menos uma língua estrangeira moderna, cuja escolha ficará a cargo da comunidade escolar, dentro das possibilidades da instituição" (Art. 26/§ 5. '). Já no Ensino Médio, prevê que "será incluída uma língua estrangeira moderna, como disciplina obrigatória, escolhida pela comunidade escolar, e uma segunda, em caráter optativo, dentro das disponibilidades da instituição" (Art. 36. ${ }^{\circ}$, III)

A nossa legislação, antes da Lei 11.161/2005, apresentava uma indeterminação das línguas estrangeiras que ocupariam a grade curricular, com falta de referência a elas, como podemos observar nos PCN:

Independentemente de se reconhecer a importância do aprendizado de várias línguas, em vez de uma única, e de se pôr em prática uma política de pluralismo lingüístico, nem sempre há a possibilidade de se incluir mais do que uma língua estrangeira no currículo. Os motivos podem ir da falta de professores até a dificuldade de incluir um número elevado de disciplinas na grade escolar. Assim, uma questão que precisa ser enfrentada é qual, ou quais línguas estrangeiras incluir no currículo. (...) Pelo menos três fatores devem ser considerados:. fatores históricos;. fatores relativos às comunidades locais;. fatores relativos à tradição.(...) Deve-se considerar também o papel do espanhol, cuja importância cresce em função do aumento das trocas econômicas entre as nações que integram o Mercado das Nações do Cone Sul (Mercosul). Esse é um fenômeno típico da história recente do 
Brasil, que, apesar da proximidade geográfica com países de fala espanhola, se mantinha impermeável à penetração do espanhol (PCN-LE, 1999, p.2223).

O espaço das línguas estrangeiras na escola passa a ser ocupado pela língua espanhola (com prioridade e preferência sobre as demais línguas) a partir desse "acontecimento discursivo" (LEMOS, 2008), que é a Lei 11.161 e, um ano depois, isto é, em 2006, que vai “desatar sentidos” como a elaboração das Orientações Curriculares para a Língua Espanhola no Ensino Médio (OCEM-Espanhol).

As OCEM-Espanhol (2006) contaram com a consultoria de uma equipe de renomados pesquisadores da área de E-ELE, dentre eles, Isabel Gretel María Eres Fernández (Faculdade de Educação) e Neide Therezinha Maia González (Departamento de Letras Modernas) da Universidade de São Paulo. Além dos consultores, o documento recebeu a leitura crítica de pesquisadores de várias instituições, dentre elas UFSCAR, UFRJ, UFMG, UERJ, UNESP.

Esse documento destaca quatro principais aspectos que se referem à concepção de Língua Espanhola que deve orientar a aprendizagem dessa língua no Brasil. São eles: 1) educação regular x ensino livre; 2) a compreensão das linguagens como significados, conhecimento e valores; 3) a hegemonia do Espanhol peninsular; 4) o grau de proximidadedistância entre o Português e o Espanhol.

Apresentam as OCEM-Espanhol que: "em primeiro lugar, é crucial que fiquem bem claras as diferenças que deve haver entre o papel da língua estrangeira e a forma de abordá-la no âmbito da educação regular e no âmbito do ensino livre” (p.131). Isso porque, a educação regular espera que a aprendizagem de uma Língua Estrangeira esteja vinculada a discussões de ordem política, social e cultural que levem à formação do estudante brasileiro no que concerne a sua autonomia e cidadania.

O segundo aspecto ressaltado pelas OCEM-Espanhol se refere à importância fundamental de se "trabalhar as linguagens não apenas como formas de expressão e comunicação, mas como constituintes de significados, conhecimentos e valores” (p.131).

Sobre a questão da hegemonia peninsular, diz o documento que é necessário que se trabalhe com uma concepção de Língua Espanhola que contemple sua diversidade de usos. Nesta concepção, o professor seria um interculturalista articulador de muitas vozes ao propiciar ao aluno a reflexão, o conhecimento dos Outros e consequentemente de si mesmo, auxiliando na compreensão dos lugares que essas múltiplas vozes ocupam. 


\subsection{O espanhol da América}

Antes de adentrarmos na temática do espanhol da América, gostaríamos de esclarecer que temos consciência em relação à diversidade linguística comum a qualquer país/região e, portanto, julgamos não ser adequada uma visão dicotômica espanhol pensinsular/europeu versus espanhol americano/hispano-americano e que lançamos mão desses termos apenas por falta de outra terminologia que nos permita facilitar a discussão a respeito do tema. Neste sentido, cabe citar mais uma vez Lope Blanch (1989), o pesquisador destacava que as diferenças que ocorrem entre a língua falada nestes países não nos permite estabelecer duas grandes modalidades bem contrastadas, espanhola e americana e, além disso, existe maior afinidade entre algumas modalidades americanas e espanholas que entre certas modalidades hispano-americanas entre si. Dessa forma, sabemos que a língua espanhola é o idioma comum a muitos países e que - como língua natural - possui diferenças - léxicas, fonéticas e, num menor grau, morfossintáticas- em situações de uso em uma ou outra região.

Diante do exposto, todos sabemos que o espanhol é uma língua com quase 500 milhões de falantes repartidos em mais de 20 países, fato que gera opiniões sobre como a língua espanhola é una e múltipla ao mesmo tempo. Quando o tema é "espanhol da América" temos que ter em mente que estamos nos referindo a uma mesma língua para dezenove países: México, Guatemala, Honduras, El Salvador, Nicarágua, Costa Rica, Panamá, Cuba, República Dominicana, Porto Rico, Venezuela, Colômbia, Equador, Peru, Bolívia, Chile, Paraguai, Uruguai, Argentina.

Se levarmos em consideração que estamos diante de uma língua geograficamente extensa e as especificidades que envolvem a aquisição desta língua por brasileiros, surgem os questionamentos: 1) Qual espanhol deve ser ensinado? 2) Que modelo interessa ter como referência para o ensino e aprendizagem do Espanhol Língua Estrangeira (E-LE) no Brasil? Estas perguntas têm respostas bastante variadas, segundo as situações:

Deve-se pensar que o simples fato de alguém encontrar-se com tais questões, está mostrando, por um lado, a existência de uma multiplicidade de opções: não existe um só modelo, manifestação ou uso da língua espanhola ${ }^{42}$ (MORENO FERNÁNDEZ, 2007, p. 10).

\footnotetext{
${ }^{42}$ No original: "Debe pensarse que el simple hecho de que alguien se plantee tales cuestiones está revelando, por un lado, la existencia de una multiplicidad de opciones: no hay un solo modelo, manifestación o uso de la lengua española”.
} 
Como nos apresenta Moreno Fernández (2007), a língua espanhola, como língua natural, é notadamente variável e apresenta uma multiplicidade de manifestações geodialetais e sociodialetais susceptíveis de serem levadas ao ensino.

Apesar disso, é aceito o princípio de unidade fundamental do espanhol, que permite que qualquer professor de espanhol bem formado, utilizando a variedade geolectal que utiliza, possa realizar seu trabalho sem dificuldade em qualquer ambiente:

É fundamental compreender que o espanhol aglomera variedades geolinguísticas e sociolinguísticas diversas. Com isso, sem querer negar o já conhecido, é evidente que a língua geral manifeste-se de forma distinta de acordo com as variáveis externas a ela, como a geografia, o tempo, a sociedade e a situação. Dessas variáveis, vamos nos deter especialmente à geografia e à sociedade, pois, é o resultado variável que as diferentes realidades geográficas e sociais do domínio hispânico provocam sobre o espanhol. A língua espanhola apresenta variedades dialetais na Europa, América e África. Também inclui falas crioulas na América (papiamento, palenquero) e na Ásia (chabacano, chamorro), e uma variedade sem divisão geográfica compacta (judeuespanhol). O professor de E/LE deve ter uma formação básica e dispor de uma informação adequada sobre a realidade dialetal da língua que ensina. É importante que conheça as características fundamentais das variedades da Europa e da América, por serem as mais difundidas e extensas ${ }^{43}$ (MORENO FERNÁNDEZ, 2007, p.22-23).

\section{Segundo as OCEM (Orientações Currriculares para o Ensino Médio - Espanhol,}

MEC, 2006, p. 134), e diante do que foi exposto aqui, faz-se necessário ir mais além da pergunta: Qual espanhol ensinar? E pensar em: Como ensinar essa língua espanhola, tão plural e heterogênea, sem sacrificar suas diferenças, e nem reduzi-las a simples amostra sem qualquer reflexão a respeito?

Neste sentido, o documento nos orienta que "nenhum falante de nenhuma língua conhece a fundo todas as variedades existentes" (p. 136) e, portanto, cada professor tem uma maneira própria de expressar-se, independente de ser falante nativo de determinado território ou ter adotado uma variedade ou, até mesmo, por ter o espanhol como língua estrangeira

43 No original: "Es fundamental comprender que el español aglutina variedades geolingüísticas y sociolingüísticas diversas. Con esto se quiere decir que, sin negar lo común, es evidente que la lengua general se manifiesta de formas distintas de acuerdo con variables externas a ella, como son la geografía, el tiempo, la sociedad y la situación. De esas variables, nos van a interesar especialmente la geografía y la sociedad, es decir, los resultados variables que las distintas realidades geográficas y sociales del dominio hispánico provocan sobre el español. La lengua española presenta variedades dialectales en Europa, América y África. Asimismo incluye hablas criollas en América (papiamento, palenquero) y Asia (chabacano, chamorro), y una variedad sin circunscripción geográfica compacta (judeoespañol). El profesor de E/LE debe tener una formación básica - y disponer de una información adecuada sobre la realidad dialectal de la lengua que enseña. Más concretamente, es importante que conozca los caracteres fundamentales de las variedades de Europa y de América, por ser las mayoritarias y las más extensas". 
acaba, inevitavelmente, mesclando fragmentos de variedades diferentes, essa seria "a sua forma 'natural' de se expressar, a que conhece melhor e à qual se sente mais vinculado. Portanto, essa deve ser a modalidade fundamental de expressar-se, em aula ou fora dela" ( $p$. 136).

As OCEM (MEC, 2006) recomendam, portanto, que o professor deve utilizar a variante que ele melhor conhece, mas alerta que, independente de qual seja a variante adotada, o professor pode se empenhar em mostrar aos alunos que existem outras, "tão ricas e válidas quanto a usada por ele, e, dentro do possível, criar oportunidades de aproximação a elas, derrubando estereótipos e preconceitos" (p.136). Dessa forma, é essencial que o professor seja um mediador intercultural, articulador de muitas vozes.

Nesta mesma linha, Hoyos Andrade (1974, p.181) refere-se ao fato de não ser fácil a tarefa de ensinar um idioma, e menos ainda quando esta língua é um complexo dialetal ou, ainda, uma amplitude de variedades regionais. Ao transmitir uma língua - una e múltipla ao mesmo tempo- deve-se dedicar ao ensino ativo de uma variedade enquanto expõe ao aluno gradualmente- um número cada vez maior de variedades.

Dessa forma, acreditamos que é necessário preparar o aprendiz para uma compreensão pluricultural e multilíngue. A respeito desta questão, compartilhamos a opinião de Moreno García (2000): vocês conhecem algum rico que reclame do fato de ter muito dinheiro? Ou seja, o professor deve começar com uma variedade e expor ao aluno um número cada vez maior de variantes.

Segundo Rona (1964), a homogeneidade do espanhol americano é um mito que pode ser atribuído "ao fato de que se começasse a falar e escrever a respeito do espanhol americano antes de ser conhecido o espanhol americano ${ }^{44, "}$ (p.125).

Neste sentido, Lope Blanch $\left(1989\right.$, p.29) ${ }^{45}$ nos aponta que:

A língua espanhola continua sendo o sistema linguístico de comunicação comum a vinte nações, no entanto, com as diferentes particularidades: léxicas, fonéticas e em menor grau, morfossintáticas- que combinam o uso em uma ou outra situação linguística. Diferenças que se complementam entre todos esses vinte países, sem nos permitir estabelecer duas grandes modalidades bem contrastadas- espanhola e americana, ademais, existe uma maior conformidade entre algumas modalidades americanas e espanholas que entre certas modalidades hispano-americanas entre $\mathrm{si}^{46}$.

\footnotetext{
${ }^{44}$ No original: "al hecho de que se empezara a hablar y escribir el español americano antes de conocerse el español americano".

45 apud Conceição Pinto (2009, p. 8).

46 No original: "La lengua española sigue siendo el sistema lingüístico de comunicación común a veinte naciones, no obstante las particulares diferencias - léxicas, fonéticas y, en menor grado, morfosintácticas - que
} 
Ao fazer a caracterização das variedades geográficas do espanhol da América, a maioria das investigações ${ }^{47}$ acompanha o esboço elaborado por Henríquez Ureña $(1921)^{48}$, e agrupa cinco áreas que seguem um comportamento semelhante:

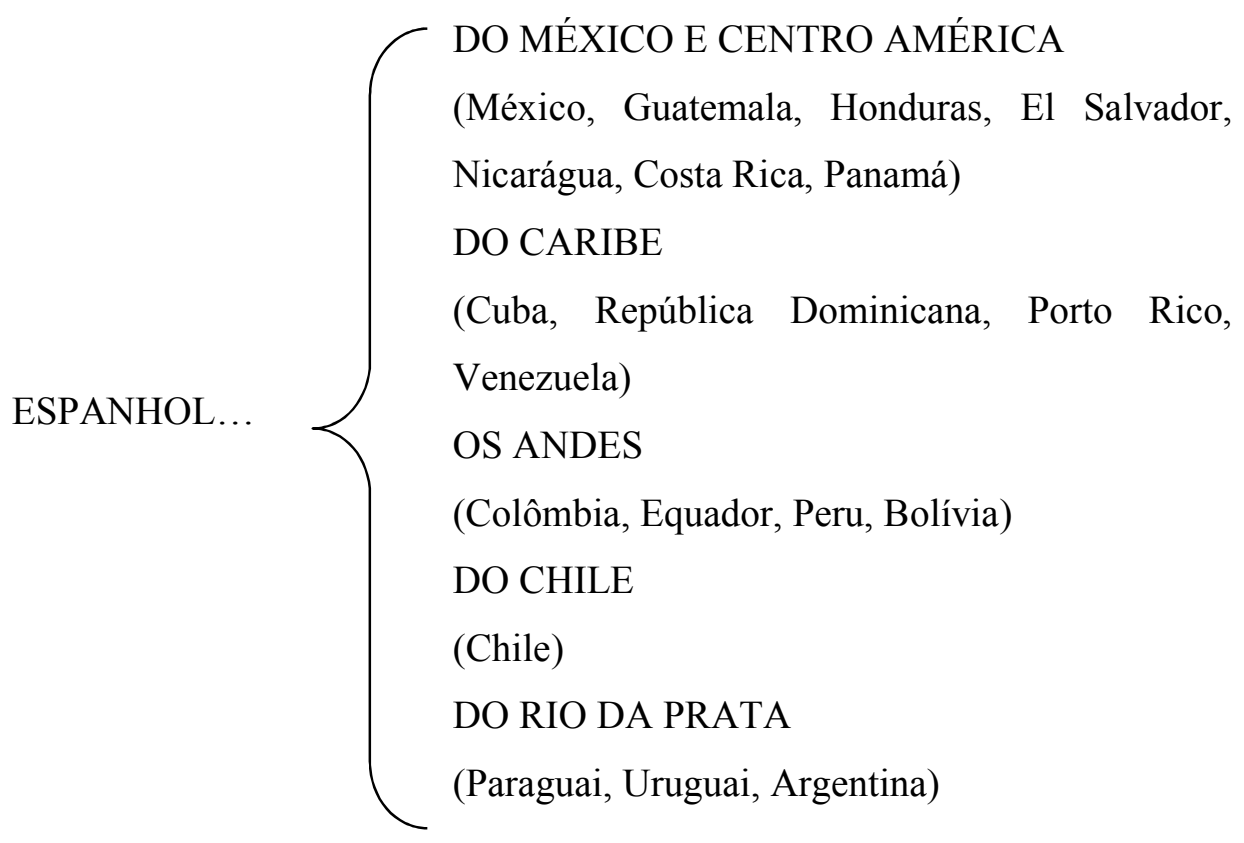

Quadro 10: Variedades geográficas do espanhol da América

Neste momento, é impossível analisar com profundidade cada um dos cinco grupos linguísticos apresentados, intento que resultaria em um texto extremamente longo e que fugiria ao objetivo desta tese, de vez que estas questões já foram tratadas em compêndios de sociolinguística e nos interessa, portanto, averiguar em um contexto empírico de formação de professores como os participantes percebem e lidam com a questão da unidade e diversidade $d a$ e $n a$ língua espanhola.

esmaltan el uso en unas y otras. Diferencias que se producen entre todos esos veinte países, sin permitirnos establecer dos grandes modalidades bien contrastadas - española y americana por cuanto que, además, existe mayor afinidad entre algunas modalidades americanas y españolas que entre ciertas modalidades hispanoamericanas entre sí".

${ }^{47}$ Como Moreno Fernández (2007, p. 41-46) e Andión Herrero (2004), por exemplo.

${ }^{48}$ apud Rona (1964, p. 216). 


\subsection{Breve apresentação da filmografia utilizada para a reflexão a respeito da unidade e diversidade na e da língua espanhola}

Conforme relatamos no item "procedimentos metodológicos", do primeiro capítulo desta tese, optamos por utilizar, no momento de tratar da temática que envolve a unidade e diversidade linguística no universo hispânico, produções que retratam memórias, histórias e territórios latino-americanos.

Esta escolha deu-se em função da invisibilidade da América Latina constatada em nossa análise preliminar do contexto: a Espanha é a mais citada quando os participantes são questionados a respeito de qual país gostariam de visitar, com a predominância de crenças como a Europa como continente superior e "dono da língua". Além disso, $71 \%$ dos participantes relatam que seria mais importante que um curso fosse iniciado com o espanhol peninsular, em detrimento do espanhol americano e, quando questionados a respeito da identificação com os falantes da língua, 59\% deles se sentiriam melhor falando como um espanhol.

Uma vez justificada a nossa escolha pelo cinema latino-americano, neste item apresentamos, brevemente, cada um dos filmes utilizados, ao longo do semestre 2013.2, com o intuito de proporcionar reflexões a respeito da variação linguística e do ensino de espanhol para brasileiros no contexto da integração latino-americana.

\subsubsection{O 'entre-lugar' ${ }^{49}$ dos bolivianos em São Paulo}

Produzida pela HBO Brasil, a série "Destino: SP" apresenta, ficcionalmente, a relação dos novos imigrantes que chegam a São Paulo, a segunda maior cidade do mundo, diariamente, com seus sonhos, esperanças, frustrações e alegrias. Os grupos abordados em cada episódio são chineses, nigerianos, israelitas, bolivianos, coreanos e argentinos. A série aborda conflitos culturais recentes e é protagonizada não por atores profissionais, mas por pessoas comuns.

Os episódios projetam as metamorfoses que os imigrantes passam para sobreviver às barreiras encontradas durante a adaptação em uma nova e complexa cidade. O amor, em todas

\footnotetext{
${ }^{49}$ Nos termos de Bhabha (1998).
} 
as manifestações: eterno, passageiro, materno, fraterno, convencional ou polêmico é destacado como foco principal e universal das relações humanas.

Para nossos momentos de reflexão, selecionamos o episódio "Dia da Independência", dirigido por Alex Gabassi, em 2012, que revela Santiago Alejandro Lima Canaviri, um garoto boliviano de nove anos com presença marcante e com uma atuação que comove.

Uma característica da série dedicada a investigar o fenômeno da imigração na maior metrópole brasileira: os atores, imigrantes reais, foram recrutados em redes sociais ou mesmo nas ruas, outro vínculo com o cinema neorrealista italiano (FILHO, 2012).

Como cada episódio é gravado na língua de origem dos imigrantes, a atuação do pequeno boliviano acrescenta força e autenticidade à narrativa. Vítima de bullying escolar, o garoto é submetido à violência dos colegas brasileiros, além de ser discriminado pelo próprio diretor da escola. Junto com a temática deste audiovisual, abordamos a história desse povo, a apresentação de alguns traços culturais e uma reflexão a respeito dos movimentos migratórios contemporâneos:

Cruzar fronteiras tornou-se um ato comum no mundo contemporâneo, em razão das múltiplas opções de mobilidade colocadas à disposição dos viajantes. Entretanto, há uma grande diferença entre aqueles que o fazem na condição de turistas e os que migram em busca de uma vida melhor, enfrentando barreiras jurídicas, exploração de sua mão-de-obra, discriminação, entre outros desafios (SILVA, 2005a, p.1).

Os movimentos migratórios contemporâneos são dinâmicos, apresentando complexas configurações e desafios. Neste intuito, a partir dos vários níveis e dimensões da exploração apresentados na película, dentre eles: Checho, o garoto boliviano, é explorado pelos colegas da escola; o padrasto dele explora outros bolivianos e, por sua vez, é explorado pelos coreanos; trabalhamos em sala com algumas notícias relacionadas à exploração da mão de obra nas indústrias de confecção em São Paulo ${ }^{50}$.

Discutimos também a concentração dos bolivianos em São Paulo e destacamos a importância da Praça Kantuta, localizada no bairro do Pari (próximo ao metrô Armênia) como preservação da memória, da cultura e da construção de um "entre-lugar" em pleno coração de São Paulo. Nela acontece a Feira Kantuta, organizada pela Associação gastronômica cultural, folclórica boliviana Padre Bento. Kantuta é o nome de uma flor típica do altiplano andino que deu origem as cores de uma das bandeiras bolivianas. O nome foi adotado para a praça devido

${ }^{50}$ Disponível em: <http:/www1.folha.uol.com.br/cotidiano/2014/02/1412492-bolivianos-sao-vendidos-em-feiralivre-no-centro-de-sao-paulo.shtml>. Acesso em: 19 jan. 2014. 
à grande presença da comunidade andina (notadamente boliviana), que ali se reúne semanalmente, aos domingos.

A praça funciona como local de encontro e resistência da cultura do altiplano. Lá, visitantes em geral podem encontrar artesanato, culinária e diversos produtos de origem, principalmente, boliviana e peruana. Além disso, os imigrantes (a maioria trabalhadores ilegais da indústria têxtil local) podem encontrar auxílio para a legalização de documentos, oportunidades de trabalho e cursos de Português-Língua Estrangeira. Bhabha (1998) destaca o papel de entre-lugares:

Esses 'entre-lugares' fornecem o terreno para a elaboração de estratégias de subjetivação - singular ou coletiva - que dão início a novos signos de identidade e postos inovadores de colaboração e contestação no ato de definir a própria ideia de sociedade (p. 20).

O pensador argumenta que o "direito" de se expressar a partir da periferia do poder e do privilégio autorizados não depende da persistência da tradição; ele é alimentado pelo poder da tradição de se reinscrever através das condições de contingência e contraditoriedade que presidem sobre as vidas dos que estão "na minoria" (BHABHA, 1998, p. 21).

Conforme destacou Arnoux (2008, 2010, 2012), o linguístico é fundamental para a integração regional e, neste sentido, é importante pensar em políticas públicas educacionais para escolas bilíngues, principalmente neste contexto. Neste sentido, compartilhamos e discutimos com os alunos a reportagem publicada recentemente a respeito da primeira escola pública bilíngue em português e espanhol, o Colégio Estadual Hispano-Brasileiro João Cabral de Melo Neto, que foi inaugurada no Rio de Janeiro ${ }^{51}$ em 2014.

\subsubsection{A vida é uma espuma e deve seguir o exemplo do mar}

E sua mãe também ${ }^{52}$, produção dirigida por Alfonso Cuarón, retrata dois amigos adolescentes mexicanos de dezessete anos, Tenoch - membro de uma família rica ligada à política - e Julio - um garoto de classe média. Em uma festa de casamento eles encontram Luisa, uma mulher atraente onze anos mais velha que eles, esposa espanhola de um primo de Tenoch. Eles a convidam para uma viagem imaginária que eles, supostamente, irão fazer. De

$51 \quad$ Disponível em: $\quad<$ http://www.ebc.com.br/noticias/brasil/2014/01/primeira-escola-publica-bilingue-emportugues-e-espanhol-e-inaugurada-no-rio $>$ Acesso em: 12 mar. 2014.

${ }^{52}$ CUARÓN, Alfonso [Dir.] Y tu mamá también. DVD, México, 2001. 
imediato, Luisa não lhes dá muita atenção, mas, posteriormente, ao receber um diagnóstico médico de que ela tem pouco tempo de vida, ela mantem esta informação em segredo e decide aceitar o convite. Diante do aceite de Julia, os dois amigos organizam a viagem, em carro, para a imaginária praia Boca del Cielo.

O filme segue a fórmula clássica de um road movie, apresentando o trajeto físico e a viaje interior, que tem sentido diferente para cada um dos protagonistas: para Julio e Tenoch é como se fosse o início da vida adulta, já para Luísa trata-se da despedida deste mundo. O trio atravessa um México rural pobre, no qual os protagonistas contrastam com pessoas e paisagens muito diferentes do seu entorno habitual.

O tom intimista como o qual começa esta história, aparentemente frívola, contrasta com os densos conflitos emocionais que desencadeia. Cuarón escolheu exibir uma parte da realidade social do México ligada à pobreza em que vive a grande maioria de sua população, o que acentua o contraste com os privilegiados protagonistas. A câmera dá a estes fundos de paisagem social um tratamento que enriquece a história ${ }^{53}$ (SALVADOR, 2009, p. 236).

Além das reflexões linguísticas ${ }^{54}$, o filme nos possibilitou incitar reflexões a respeito de outras temáticas, dentre elas, a liberdade, a coragem, a sensibilidade, a natureza, o sexo, a amizade e o ingresso na vida adulta, bem como refletir que nada é eterno e que a vida é composta por fases como descobertas, aceitações e fechamentos. Conta com o recurso da narrativa com o corte do áudio para que o narrador revele como terminará as histórias de alguns personagens secundários.

Torna-se um pouco perturbador perceber que a maioria das histórias de vida não tem nada de especial e a maioria de nós passará por esse mundo sem fazer muita diferença para a humanidade. Com sorte, a gente consegue fazer a diferença na vida de algumas pessoas que nos rodeiam e, no fim, o que sobra? O que realmente vale a pena? A narrativa propicia a reflexão a respeito do que sobra no final da vida, quando estamos à beira da morte, o que realmente fica? O que valeu a pena? O filme explora a metáfora "la vida es como la espuma, por eso hay que darse como el mar", que interpretamos como sendo a espuma transitória, criada rapidamente, ganha volume e quando menos se espera se consome pouco a pouco até tornar-se nada, e assim é a vida. Dessa forma, a espuma poderia se comportar como o mar:

${ }^{53}$ El tono intimista con que arranca esta historia, aparentemente frívola, contrasta con el denso conflicto emocional que se desencadena. Cuarón elige mostrar una parte de la realidad social de México ligada a la pobreza en que vive gran parte de su población, lo que acentúa el contraste con los privilegiados protagonistas. La cámara da a estos fondos de paisaje social un tratamiento que enriquece la historia

${ }^{54}$ No caso da variação lexical, contamos principalmente com o Proyecto de Jergas de Habla Hispana, Disponível em: < http://www.jergasdehablahispana.org/> Acesso em: 15 mai. 2013. 
com força, coragem, sem se prender, ainda que haja pedras, barcos, montanhas, ele sempre busca o seu caminho, independente dos obstáculos, ele se impõe para seguir seu caminho.

\subsection{3 "Dizem que tem sete línguas a boca do dragão. Eu não sei. Mas me consta que muitas mais línguas têm a boca do mundo e o fogo de suas línguas nos abriga... ${ }^{55 \% "}$}

O filme 7 cajas $^{56}$, produção paraguaia de 2012, dirigida por Juan Carlos Maneglia e Tana Schembori, apresenta a realidade linguística paraguaia. A projeção leva à tela o Mercado 4 de Assunção, considerado como um espaço multicultural e plurilíngue, já que as pessoas que por ali transitam se comunicam em espanhol, guarani, inglês, chinês, árabe, coreano e hebreu. Junto com essas línguas, podemos observar que há manifestações do uso contínuo do yaporá (o uso alterando em um mesmo período discursivo do espanhol e do guaraní) pela grande maioria das pessoas que convivem naquele ambiente.

Logo no início da projeção, após a apresentação do cenário, o mercado 4 de Assunção, somos apresentados ao nosso personagem principal, Víctor, de 17 anos, um carreteiro que se distrai sonhando em algum dia ser famoso e aparecer nas telinhas das televisões que lotam as lojas do grande mercado. Este tempo empreendido pelo nosso protagonista numa loja de DVD's tem como consequência a perda de um cliente para outro carreteiro. $\mathrm{O}$ ambiente do mercado é hostil, competitivo e há milhares como ele esperando levar as compras dos clientes em troca de alguma gorjeta.

Diante da oportunidade de trabalho perdida, Victor fica inquieto e começa a se mover na busca por algum bico que lhe renda algum dinheiro para ganhar o dia. É neste movimento que recebe uma proposta inusitada: transportar 7 caixas, sem conhecer seu conteúdo, em troca de uma nota rasgada de 100 dólares: metade é recebida como sinal e a outra metade do dinheiro seria entregue quando terminasse o seu trabalho.

Para orientá-lo durante o dia, o responsável das caixas lhe empresta um celular e Víctor inicia seu trajeto. De imediato, cruzar o mercado parecia fácil, mas as coisas vão se complicando: tem uma das caixas roubada, perde o celular e a polícia rodeia o mercado buscando algo que ele ignora por completo. A isso se soma um grupo de carreteiros dispostos a roubar as caixas na expectativa de que elas estejam cheias de dinheiro.

55 ...Será sempre pouco quanto se faça para defendê-las do desprezo e do extermínio (Eduardo Galeano In: LAS LENGUAS, 2007).

${ }^{56} 7$ cajas (MANEGLIA, Juan Carlos; SCHEMBORI, Tana [Dir.] 7 cajas. DVD, Paraguai, 2012); 
Sem ao menos imaginar, Víctor e os carreteiros que o perseguem estão envolvidos em um crime do qual não sabem a causa, a vítima e muito menos o culpado. No final do dia Víctor entende que, sem querer, acaba se tornando cúmplice de algo muito perigoso e, ainda que de forma conturbada e não planejada, ele realiza seu sonho de conquistar alguns minutos de aparição na TV.

Uma consistente análise da questão linguística representada neste filme pode ser encontrada em Pascua Vílchez (2014). O autor se filia à sociologia da linguagem e discorre a respeito da identidade linguística dos grupos sociais, as atitudes perante a língua, o bilinguismo e multiculturalismo, a alternância e mistura de códigos presentes no filme.

Com o propósito de estabelecer relações entre os códigos linguísticos (espanhol, guarani e jopará) e o contexto social em que são usados, o pesquisador constata que a escolha de uma ou outra língua pelos personagens está relacionada com determinados contextos de uso e estereótipos sociais e argumenta que a situação linguística daquele país está mais ligada a uma situação de diglossia ${ }^{57}$ que de bilinguismo.

Esta produção cinematográfica nos possibilitou trabalhar, dentre outras coisas, com a conscientização a respeito das várias modalidades de bilinguismo no território latinoamericano. Conforme relatou Arnoux (2012), um dos desafios linguísticos da integração consiste em construir uma trama tal que o espanhol-português se acompanhe do fortalecimento das línguas indígenas, e que o seu conhecimento seja transmitido, também com diferentes modalidades, à população não indígena.

\subsubsection{Um passeio pelas lendas e culturas peruanas}

A produção peruana El misterio del Kharisiri, de 2004, dirigida por Henry Vallejo, explora a questão do sobrenatural por meio do mito do Kharisiri, um personagem andino ligado à bruxaria que pode possuir a forma que desejar a fim de alcançar seus objetivos. É, geralmente, representado por um bruxo com poderes para interceder no destino dos homens mediante o pagamento de dinheiro.

\footnotetext{
${ }^{57}$ Os pesquisadores da área argumentam que a diglossia é uma situação social na qual uma comunidade de fala utiliza duas variedades de uma língua (diglossia no sentido estrito - Ferguson (1959)) ou duas línguas distintas (diglossia no sentido amplo - Fishman (1972)) em âmbitos e para funções sociais diferentes (CENTRO VIRTUAL CERVANTES, 2014).
} 
A principal história contada pelo filme é a de um casal de jornalistas que investigam um roubo no município de Pomata envolvendo o filho do prefeito. Uma repórter e o câmera investigam o desaparecimento e se veem em uma rede de acontecimentos no mínimo estranhos, rituais e mortes.

A fotografia do filme nos apresenta um entorno belo entorno natural, com cavernas, construções arqueológicas, lagoas, igrejas. Além das questões linguísticas, exploramos com os alunos o papel da imprensa, como ela é vista pelas autoridades locais e a sua função como formadora de opiniões e de informações para a sociedade.

\subsubsection{Manutenção do Status quo?}

Ambientado no Chile de 1973, Machuca $^{58}$ nos apresenta dois garotos de 11 anos, Gonzalo e Pedro, que vivem na capital do país. Pinheiro (2010) relata que a narrativa pode ser dividida em três fases. Na primeira, há a apresentação de Gonzalo, gordinho, solitário, afeito as regras, até que sua rotina é quebrada com o ingresso de meninos pobres na escola privada em que estuda. No desenvolvimento, o espectador acompanha a amizade que floresce com o menino pobre Pedro Machuca, os conflitos causados pela desigualdade social, até culminar com o desenlace em que a situação social não permite a continuidade desta amizade.

De universos tão próximos e tão distantes, já que o primeiro vive num bairro elegante e o segundo numa favela, a vida deles se cruza quando o diretor do colégio de Gonzalo dá início a um processo de integração escolar de garotos pobres:

Machuca, o segundo longa-metragem de Andrés Wood, recolhe eventos que ocorreram no doloroso 1973 chileno - o ano do golpe de Pinochet contra Allende - para transformá-los em ficção histórica. O personagem do Padre McEnroe é baseado no diretor do Saint's George's College, o padre Gerardo Whelan, que implementou um programa de integração social na escola católica que dirigiu de 1969 até sua demissão em 1973. Para ele é dedicado este filme tão perfeito como necessário. Machuca contou com um generoso orçamento que seus realizadores souberam converter no que será um clássico do cinema latino-americano ${ }^{59}$ (SALVADOR, 2009, p.247).

\footnotetext{
${ }^{58}$ WOOD, Andrés [Dir.] Machuca. DVD, Chile, 2004.

${ }^{59}$ No original: "Machuca, segundo largometraje de Andrés Wood, recoge acontecimientos que ocurrieron en el doloroso 1973 chileno - el año del golpe de Estado de Pinochet contra Allende - para convertirlos en ficción histórica. El personaje del padre McEnroe está basado en el rector del Saint's George's College, el padre Gerardo Whelan, quien implantó un programa de integración social en el colegio católico que dirigió desde 1969 hasta su destitución en 1973. A él está dedicada esta película casi tan redonda como necesaria. Machuca dispuso de un generoso presupuesto que sus realizadores supieron convertir en lo que será un clásico del cine latinoamericano".
} 
O conflito principal do filme é o embate entre a classe social abonada que perdia privilégios, e os mais pobres, que ansiavam pelas mesmas oportunidades, exemplificada pelo acesso dos meninos pobres ao colégio de elite de Santiago, durante o período do governo de Salvador Allende. Registrada a partir do olhar de uma criança, a história representa um duro enfrentamento de classes retratado com um enfoque mais social do que político, os personagens são verossímeis e a história está bem ambientada. Ao longo da projeção, várias situações e diálogos dão destaque à diferença entre os meninos e anunciam que não há espaço para amizade entre pessoas de diferentes classes sociais.

Um dos pontos fortes do filme é a sequência em que o pai alcoólatra do menino pobre, ao chegar a casa e ver ele com o seu amigo, ironiza a relação de amizade entre os dois:

Ismael (pai de Pedro): Quem é aquele:

Pedro: Um amigo.

Ismael: Um amigo, certo? Você tem cada amigo... Sabe onde seu amigo estará daqui a cinco anos? Começando a faculdade. E você vai limpar banheiros. Em dez anos, estará trabalhando com o pai dele. E você vai estar limpando banheiros. Em quinze anos, o seu amigo vai ser dono da empresa do pai. E você? Adivinha só? Você ainda vai estar limpando banheiros. Ele sequer irá lembrar o seu nome. O seu amigo... (WOOD, 2004).

Além das atividades realizadas antes, durante e depois da exibição do filme para a conscientização linguística a respeito do espanhol do Chile, discutimos com os participantes o texto "Bourdieu e a educação" de Hey e Catani (2008) e os alunos foram estimulados a relacionar temas como a escola enquanto reprodutora da dominação e conhecimento e poder com a temática apresentada pelo filme.

\subsection{6 "Era um homem que tinha tudo: para ele só faltava ser pai, ser filho e sem homem"}

O filme O Filho da novia ${ }^{60}$, concorrente argentino ao Oscar de melhor filme estrangeiro em 2001, nos apresenta Rafael Belvedere que está em crise, pois assumiu muitas responsabilidades e não tem mais tempo para qualquer tipo de diversão. Boa parte de seu tempo é gasto no gerenciamento do restaurante fundado pelo pai, no qual até tem um relativo sucesso, mas sem nunca conseguir escapar da sombra dele:

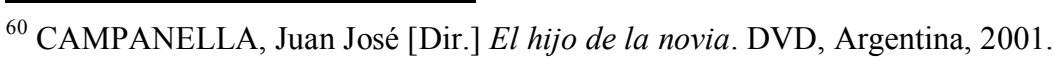


Um quarentão que diz ser o que não é que vive angustiado pela instabilidade econômica do seu restaurante, que terminou por deixar de lado seus vínculos afetivos para dedicar-se ao seu negócio, herdado de seus pais. Seu dia a dia é agitado, vive com o telefone nas mãos para segurar seus fornecedores e cobrir suas dívidas bancárias. Quase não encontra tempo para ficar com sua pequena filha, compartilhar as refeições com seu pai, e manter uma frágil relação amorosa com Naty, e ainda visitar sua mãe, Norma, uma vez ao ano, que vive em um abrigo e sofre do mal de Alzheimer. Um dia, seu pai pede sua ajuda para poder concretizar um plano: quer casar com sua mãe na igreja, para satisfazer um desejo que a negou há quarenta anos. Em meio ao estresse descontrolado, o filho não dá importância ao pedido do pai, e tenta disfarçar. No entanto, um episódio dramático e a reaparição de um amigo de infância leva Rafael a reconsiderar o pedido de ajuda ${ }^{61}$ (SALVADOR, 2009, p. 232).

Rafael raramente visita sua mãe, Norma, que sofre de uma terrível enfermidade neurológica e está perdendo a memória. O filme nos apresenta a Argentina contemporânea e nos possibilitou abordar questões linguísticas como o espanhol rio-platense, o cocoliche $^{62}$, o lunfardo $^{63}$ e o voseo $^{64}$ e, além disso, nos convida a refletir a respeito da velhice, da maturidade, das responsabilidades afetivas, das relações familiares, da memória e da ideia de êxito.

\footnotetext{
${ }^{61}$ No original: "un cuarentón algo fanfarrón agobiado por la inestabilidad económica que le reporta su restaurante, ha terminado por desatender los vínculos afectivos en pos de conservar su negocio, heredado de sus padres. Su día a día es un continuo maratón teléfono en mano, para retener proveedores y tapar agujeros bancarios. Apenas le queda tiempo para hacerse cargo de su pequeña hija, compartir alguna comida con su padre, sostener una frágil relación amorosa con Naty y visitar una vez al año a su madre, Norma, que vive en una residencia y tiene mal de Alzheimer. Un día, su padre le pide ayuda para llevar a cabo un proyecto: quiere casarse con su madre por la Iglesia, para complacerla en algo que le negó cuarenta años atrás. En medio del estrés desenfrenado, el hijo trivializa el pedido e intenta distraer al anciano. Pero un episodio dramático y la reaparición de un amigo de la infancia llevan a Rafael a reconsiderar tan singular reclamo (SALVADOR, 2009, p.232)".

${ }^{62}$ Segundo Soca (2004), o cocoliche, definido como "gíria hibrida que certos imigrantes italianos falam na Argentina, mesclando seu idioma com o espanhol", passou a ser uma palavra do idioma espanhol que compõe o dicionário da Real Academia desde sua edição de 1927.

${ }^{63}$ O lunfardo é um léxico nascido de uma origem tripla: a gíria criminosa dos ladrões, como base, a fala dos subúrbios e a fusão linguística imigratória representada nos cortiços portenhos. (...) Se gera e se desenvolve entre 1870 a 1920, aproximadamente, e se propaga por escrito em letras de tango e em textos de sainetes e comédias. (...) Trata-se de um dialeto popular portenho. Atualmente, existe uma tendência ao "panlunfarismo", que consiste em considerar e qualificar de "lunfarda" a toda manifestação coloquial de fala em Buenos Aires: a dos dependentes de drogas, do futebol, do hipismo, e da música popular atual (ACADEMIA ARGENTINA DE LETRAS, 2004, p. 71).

${ }^{64}$ Em algumas partes da América Latina se utiliza o voseo, tratamento que consiste em usar o vos (apócope de vosotros) para dirigir-se a uma pessoa em lugar do pronome tú. Conforme apresentam alguns pesquisadores, durante muito tempo o vos não passou de uma forma coloquial, própria da fala popular, repudiada na linguagem escrita. Mas há uns 50 anos, ao ser adotado por escritores latino-americanos renomados, parece ter sido incluído também na escrita. Atualmente, encontramos o voseo na imprensa, no cinema, na publicidade de países como Argentina e Uruguai. Também aparecem em grande parte do Paraguai, Guatemala, El Salvador, Nicarágua e México (SOUZA, 2012).
} 
Trata-se de um filme leve, engraçado, triste, feliz e real. Principalmente nos dias de hoje, onde a falta de tempo e o stress do dia a dia nos faz perder os momentos mais felizes que são as coisas mais simples da vida, como a família.

\subsubsection{Um convite para colocar a mochila nas costas e conhecer a América Latina}

Che Guevara era um jovem estudante de Medicina que, em 1952, decide viajar pela América do Sul com seu amigo Alberto Granado. A viagem é realizada em uma moto, que acaba quebrando após oito meses. Eles, então, passam a seguir viagem por meio de caronas e caminhadas, sempre conhecendo novos lugares.

Em Diários de motocicleta ${ }^{65}$, podemos observar e levar os alunos a refletir a respeito de muitas características histórico-culturais da América do Sul (Argentina, Chile, Venezuela, Peru) e é possível empreender um passeio por belos cenários naturais. Este filme, em que prevalece o uso da variedade linguística rio-platense, nos permite abordar o despertar da consciência de uma América Latina como construção cultural e não apenas geográfica.

Nas palavras do protagonista do filme,

Cremos, e depois desta viagem ainda mais firmemente que antes, que a divisão da América em nações incertas e ilusórias é totalmente fíctícia. Constituímos uma só raça mestiça, desde o México até o Estreito de Magalhães apresenta notáveis semelhanças etnográficas. Por isso, tratando de tirar de mim toda carga de provincialismo exíguo, brindo pelo Perú y por toda a América unida ${ }^{66}$ (SALLES, 2004).

$\mathrm{Na}$ tela é projetada uma excelente história, lindas paisagens e elaborados diálogos que nos convidam à reflexão. Somos envolvidos nas diversas possibilidades de uma viagem digna de muita coragem e pouco preparo, pela América do Sul, sua cultura, muita desigualdade social e um povo alegre e hospitaleiro, apesar das diversas adversidades que passam.

Drexler compôs uma canção que parece que fora predestinada para o filme. A maior parte de nós acaba fazendo a travessia do rio no fim da projeção. Na palavra dos protagonistas: "esse não é um relato de façanhas impressionantes. É uma parte de duas vidas registradas num momento que cursaram juntas um determinado trecho com identidade de

\footnotetext{
${ }^{65}$ Diários de motocicleta (SALLES, Walter [Dir.] The Motorcycle Diaries. DVD, Argentina, 2004).

${ }^{66}$ No original: "Creemos, y después de este viaje más firmemente que antes, que la división de América en nacionalidades inciertas e ilusorias es completamente ficticia. Constituimos una sola raza mestiza que desde México hasta el estrecho de Magallanes presenta notables similitudes etnográficas. Por eso, tratando de quitarme toda carga de provincialismo exiguo, brindo por Perú y por toda América unida".
} 
aspirações e conjunções de sonhos". O convite à reflexão continua: "nossa visão foi muito estreita? Muito parcial? Muito precipitada? Nossas conclusões foram rígidas demais? Talvez. Mas esse vagar sem rumo por uma América maiúscula me mudou mais do que eu pensei. Eu já não sou eu. Pelo menos já não sou mais o mesmo em meu interior”. Enfim, um espetáculo da identidade latina, da nossa identidade.

\subsubsection{Política e sexualidade em Morango e chocolate}

Um dos grandes filmes da década de 1990, dirigido por Tomás Gutiérrez Alea e Juan Carlos Tabío, Fresa y Chocolate $^{67}$ ganhou vários prémios internacionais e foi o primeiro filme cubano indicado ao Oscar de melhor filme estrangeiro. Acabou tornando-se um clássico do cinema cubano e um filme imprescindível do cinema rodado em língua espanhola.

A película leva à tela um belo registro artístico da diversidade linguística, cultural e sexual, e nos apresenta ser possível existir amizade entre dois homens que, de início, parecem não ter nada em comum: Diego, artista homossexual que sofre discriminação como em qualquer país do mundo, culto e liberal, transpira cultura, não deseja a intervenção estrangeira, mas cita ter o regime cubano falhas como qualquer outro e David, um jovem heterossexual, filho de camponeses que, graças à revolução, tem acesso à universidade, militante comunista, aceita tudo o que é imposto pelo governo, sem ousar questionar, tal qual uma doutrina religiosa.

A obra projeta o povo e a cultura cubana e apresenta discussões e reflexões a respeito de sua complexa realidade histórica. A narração flui com ótimas atuações e repleta de ricos diálogos. O tema da tolerância e discriminação, a partir de estereótipos opostos é retratado de forma articulada, formando belas metáforas:

Curiosamente, em um filme que aborda de frente a questão gay, as três sequências de cama são heterossexuais. Poderia-se dizer que é uma defesa da homossexualidade (morango) feita pela heterossexualidade (chocolate), assim como uma crítica ao comunismo feita pelos comunistas. Existe uma metáfora melhor para a tolerância? ${ }^{68}$ (SALVADOR, 2009, p.190).

\footnotetext{
${ }^{67}$ Morango e Chocolate (GUTIÉRREZ ALEA, Tomás; TABÍO, Juan Carlos [Dir.] Fresa y Chocolate. DVD, Cuba: 1993).

${ }^{68}$ No original: "Resulta curioso que en una película que aborda frontalmente la temática gay, las tres secuencias de cama sean heterosexuales. Podría decirse que es una defensa de la homosexualidad (fresa) hecha por la heterosexualidad (chocolate), así como una crítica al comunismo hecha por comunistas. ¿Existe una metáfora mejor de la tolerancia?".
} 
Do contato entre Diego e David fluem diálogos produtivos que exploram, com bastante profundidade, temas como a liberdade de expressão, a segurança e soberania nacional e o patriotismo. A mistura saborosa e enriquecedora do morango com o chocolate pode ser interpretada como uma metáfora da mistura de produtos diferentes, peculiares, que já são bons individualmente, mas podem ser melhor ainda combinados.

Diego, o protagonista do filme, argumenta que Davi deve respeitar sua vocação e estudar literatura, se é o que ele realmente gosta, e não ciência política. Neste sentido, ele argumenta: "tenho um amigo que quando criança tinha um talento extraordinário para piano, mas seu pai foi contra, dizendo que arte era coisa de afeminados. Hoje meu amigo tem 60 anos, é boiola e não sabe tocar piano”. Este filme tem potencial artístico e sensibilidade para atrair ao homossexual e ao heterossexual, ao comunista e ao liberal, ao que sabe, ou não tocar piano, de forma a mostrar que apesar de divergências políticas e sexuais a amizade e o amor, em sentido amplo, podem acontecer.

\subsection{Considerações}

Este capítulo contribui com os objetivos de promover a difusão do Espanhol-Língua Estrangeira em uma abordagem dirigida à integração com vistas à interculturalidade, à alteridade e à diversidade linguística já que sabemos que o linguístico é um elemento fundamental para a integração.

Balanceamos as questões linguísticas com a reflexão política (incluindo aqui as políticas públicas em torno das línguas, logo, políticas linguísticas), pela necessidade de despertar, via ensino, uma consciência de América Latina. Destacamos a questão do espanhol enquanto língua multidimensional e intercultural, e refletimos a respeito de como equacionar tudo isso no dia a dia da sala de aula de espanhol para brasileiros e, é claro, o cinema oferece sua contribuição no assunto.

Ao pensarmos na formação docente para o ensino do espanhol enquanto língua multidimensional e intercultural, surgem algumas inquietações: (i) Quais são as crenças dos professores que levarão a cabo a missão de promover esse ensino? (ii) De que forma esse profissional valorizará as diferenças culturais experimentadas pelos diversos países onde esta língua é falada? (iii) Este educador levará em conta a necessidade de um ensino que promova a integração dos países latino-americanos? (iv) Como poderão contribuir para a construção de 
uma identidade linguística que represente a América Latina frente aos demais blocos políticos econômicos mundiais?

Neste sentido, pensar e construir a noção de alteridade pressupõe uma infinidade de caminhos possíveis e os desafios implicados. Assim, o reconhecimento do "outro" como constituinte, parte integrante de si, deve ultrapassar a teoria, para que a alteridade chegue aos alunos concretamente e, principalmente, seja reconhecida nas situações e acontecimentos cotidianos, como um valor social e educacional dos mais relevantes.

Aquilo que esperamos dos nossos alunos da educação básica deve ser, antes, objetivo da formação de professores. Dessa forma, a articulação das diversas tecnologias e os multiletramentos de forma a promover a conscientização a respeito da unidade e diversidade linguística no ensino de línguas, bem como a noção de interculturalidade deve ser apropriada primeiramente pelo docente, para, aí sim, alcançar o âmbito dos educandos. O caminho a ser traçado neste sentido é longo e necessita de uma continuidade - tanto teórica, quanto prática-, para que as diferentes formas de preconceito sejam dissipadas em prol da compreensão do outro e de suas múltiplas identidades.

O próximo capítulo está dedicado à compreensão do cinema em nossa contemporaneidade, bem como as contribuições da sétima arte para a compreensão e potencialização do complexo processo de ensino-aprendizagem. 
CAPÍTULO 4

CONTRIBUIÇÕES DA SÉTIMA ARTE PARA A COMPREENSÃO E POTENCIALIZAÇÃO DO PROCESSO DE ENSINO-APRENDIZAGEM 
Compreender um filme não é essencialmente uma prática estética; é uma prática social que mobiliza toda uma gama de sistemas no âmbito da cultura (TURNER, 1997, p.169).

A arte não pode mudar o mundo, mas pode contribuir para a mudança da consciência e impulsos dos homens e mulheres que poderiam mudar o mundo (Hebert Marcuse).

A função política da estética é a educação espiritual (Glauber Rocha). 
Conforme já destacamos anteriormente, as reflexões apresentadas ao longo desta tese são mediadas pelo cinema, considerado - conforme a perspectiva sociocultural - como artefato cultural, ferramenta de mediação simbólica potencializadora do desenvolvimento humano. Ao adotarmos termos como artefato e ferramenta, não pretendemos reduzir a arte a um mero caráter utilitário. Pelo contrário: segundo a perspectiva sociocultural que comungamos, estes termos ganham uma dimensão mais ampla já que a relação homem-mundo é mediada por artefatos e ferramentas físicas, sociais e simbólicas, como explicaremos a seguir.

Para Vigotski (2007, 2009), a relação do homem com o mundo não é uma relação direta, mas, fundamentalmente, mediada por sistemas simbólicos. Complementando, Vieira Abrahão (2012) nos apresenta a mediação como um conceito central da teoria sociocultural, sendo o "processo por meio do qual os seres humanos se utilizam de artefatos culturalmente construídos, de conceitos e de atividades para regular o mundo material ou seu próprio mundo e suas atividades sociais e mentais reciprocamente" (p. 5).

Assim, a mediação pode ocorrer por instrumentos ou signos:

O signo age como um instrumento da atividade psicológica de maneira análoga ao papel de um instrumento no trabalho. Os instrumentos, porém, são elementos externos ao indivíduo, voltados para fora dele; sua função é provocar mudanças nos objetos, controlar processos da natureza. Os signos, por sua vez, também chamados por Vygotsky de 'instrumentos psicológicos' são orientados para o próprio sujeito, para dentro do indivíduo; dirigem-se ao controle de ações psicológicas, seja do próprio indivíduo, seja de outras pessoas. São ferramentas que auxiliam nos processos psicológicos e não nas ações concretas, como os instrumentos (OLIVEIRA, 1993, p. 30).

Em consonância com esta reflexão, Johnson (2009) acrescenta que as ferramentas das quais lançamos mão para a mediação da nossa relação com o mundo podem ser físicas, sociais ou simbólicas.

A partir das considerações expostas, neste capítulo, partindo do pressuposto de que nossas reflexões acerca das crenças que permeiam a aquisição da língua espanhola e o tratamento da variação linguística por professores brasileiros deste idioma em formação inicial serão mediadas pelo cinema, apresentaremos o potencial da sétima arte em levar à tela de projeção a vida em seus múltiplos aspectos.

Teceremos considerações a respeito das várias vias de estudo com vistas à compreensão do cinema, com foco na indústria, nas artes, nas invenções, no entretenimento e ressaltamos seu potencial para propiciar a compreensão da cultura escolar, bem como sua capacidade de potencializar o processo de ensino-aprendizagem. 
Conforme já relatamos na introdução, nesta tese empregamos o termo cinema em sentido amplo, como imagem em movimento, independente do suporte, exceto quando fizermos referência explícita nesse sentido.

A primeira sessão. 28 de dezembro de 1895. No salão indiano do Grand Café, em Paris, os trinta e três convidados dos irmãos Lumière vão assistir a um extraordinário espetáculo. Sobre uma pequena tela, uma fotografia recém-projetada de repente ganha vida. Carros, cavalos, pedestres começam a andar. Toda a vida de uma rua aparece. 'Diante desse espetáculo, ficamos boquiabertos', declarará o célebre prestigiador Georges Méliès. A invenção em breve vai atrair multidões e dar volta ao mundo (MARCHAND, 1995, p.6).

É consenso entre os estudiosos que a definição inicial para o cinema foi uma técnica de registro do movimento. Entretanto, ao longo da história, com acréscimos de elementos estéticos, sons, mudança de planos, angulações, enquadramentos, movimentos de câmera, iluminações e tecnologias, o cinema passou a ser denominado "a sétima arte", constituindo uma das mais ricas e completas manifestações artísticas desenvolvidas pelo ser humano, graças à possibilidade de englobar os demais processos de criação artística - música, pintura, escultura, teatro, literatura e dança.

Com o propósito de acrescentar mais sentido ao enunciado fílmico e atribuir-lhe maior verossimilhança, várias técnicas e procedimentos foram criados e aprimorados, dentre eles o uso da edição (arranjo das sequências na tela, a montagem cinematográfica em si); o fade-out (método de transição ou fechamento que provoca o desaparecimento gradual da imagem); o lap-dissolve (sobreposição gradual de uma nova imagem); a adoção do som e da cor na tela do cinema; a substituição do "ator" por "gente de verdade" (filmes neorrealistas); cenas externas $v s$ filmagens de estúdios; a adoção da noção de gênero no cinema; maior atenção para a composição das tomadas - mise-en-scène- do que para a sua combinação - montagem(com vistas à valorização do movimento dos elementos cinematográficos, do posicionamento de figuras e cenas pela câmera, da iluminação, do foco de profundidade.

Além de representar a vida, a arte cinematográfica dá forma às inquietações e aos desejos mais íntimos da alma humana. Em geral, os filmes reúnem extraordinário número de informações nas diferentes áreas da experiência e, ao longo do tempo, as discussões relacionadas ao cinema têm perpassado diversos focos: indústria, artes, invenções, entretenimento, etc.

Silva (2006), ao tecer reflexões acerca do cinema e os vínculos sociais, utiliza a cena do filme Ônibus 174 em que aparece o ônibus com o sequestrador, de arma na mão, com um apanhado de corpos confinados pelo terror num veículo estático, como uma metáfora da vida 
contemporânea. Para ela, apesar da "violência do filme, um ônibus parado e um entorno de imagens em movimento são metáforas da vida urbana, território atual do sedentarismo de seres que eram, na sua sociabilidade inicial, nômades (p.227)".

De acordo com a autora, o cinema realiza, para o homem sedentário, a viagem que o espírito anseia, sem que haja a necessidade de deslocamento de lugar. Apesar de o movimento relacionar-se ao prazer, no cinema há a dualidade entre esse e a angústia devido ao fato de ser o movimento nada mais do que um contínuo de imagens luminosas em fotogramas sucessivos que são ampliados de forma simbólica pela montagem. É ele o responsável por transformar as lacunas entre os fotogramas, intermediando a ligação com o sentido do movimento. "A imagem-movimento do cinema é, assim, um 'entre', um ponto médio entre duas imagens, como pretende Deleuze, uma ausência-presença que simboliza a perfeição, o conflito prazer angústia produzida pelo cinema” (p. 228).

O cinema, além de mascarar a saciedade de carência de movimento deste homem que um dia foi nômade, cumpre a função da fabulação necessária ao espírito, conforme nos apresenta Cândido (1995). A partir das afirmações deste autor, podemos apreciar a arte como uma necessidade básica, já que se trata da manifestação universal de todos os homens em todos os tempos:

Não há povo e não há homem que possa viver sem ela, isto é, sem a possibilidade de entrar em contato com alguma espécie de fabulação. Assim como todos sonham todas as noites, ninguém é capaz de passar as vinte $\mathrm{e}$ quatro horas do dia sem alguns momentos de entrega ao universo fabulado. O sonho assegura durante o sono a presença indispensável deste universo, independente da nossa vontade. E durante a vigília a criação ficcional (...) está presente em cada um de nós, analfabeto ou erudito, como anedota, causo, história em quadrinho, noticiário policial, canção popular, moda de viola, samba carnavalesco. Ela se manifesta desde o devaneio amoroso ou econômico no ônibus até a atenção fixada na novela de televisão ou na leitura de um romance (p. 242).

Ao argumentar sobre o direito à literatura, que - neste contexto - expandimos às artes, grupo no qual o cinema se encaixa, sabemos que as manifestações artísticas correspondem "a uma necessidade universal que deve ser satisfeita sob pena de mutilar a personalidade, porque pelo fato de dar forma aos sentimentos e à visão do mundo ela nos organiza, nos liberta do caos e, portanto, nos humaniza" (CÂNDIDO, 1995, p. 256).

Humanização aqui é entendida como um processo que caracteriza o homem com traços ditos essenciais: capacidade de refletir, de adquirir conhecimento e sabedoria, boa 
disposição ao relacionar-se com o outro, afinamento das emoções e capacidade de percepção do que é belo e complexo.

\subsection{O cinema nos permite outras maneiras de olhar para o mundo e, assim, compreender a nós mesmos}

Ao adentrar a sala de projeção somos envolvidos por um emaranhado de imagens e sons que atingem nossa alma e afetam diretamente nossas paixões, frustrações, ânsias e perturbações.

Uma breve análise pela trajetória do cinema nos revelará que, desde a década de 1960, a sétima arte vem passando por uma mudança de abordagem e tem se transformado em um dos mais fortes canais de comunicação e significação sociocultural. Para além da expressão de um meio de comunicação, o cinema hoje atua como elemento de representação da cultura, da ideologia e da percepção humana.

É bem menos radical agora do que seria há dez anos considerar a compreensão do cinema como uma investigação não só de um meio de comunicação expressivo e representacional, mas também das atuações da cultura e da ideologia (TURNER, 1997, p.170).

Neste sentido, Turner (1997), ao apresentar-nos o cinema como prática social, nos alerta para o fato de que compreender um filme não é essencialmente uma prática estética; é uma prática social que mobiliza toda uma gama de sistemas no âmbito da cultura. Dessa forma, o sujeito reestabelece relação com aquilo que é produzido a partir de sua atividade enquanto atuante na história, fazendo da grande arte o produto humano mais digno no plano coletivo. Num fluxo de reapropriação da arte, o sujeito humano encontra-se consigo mesmo, e assim é capaz de novamente intervir na história.

Atualmente, ao pensarmos no cinema a partir do tema arte e entretenimento, devemos levar em consideração que ele vai além da projeção do filme, constituindo um complexo sistema composto por elementos bastante diversificados, tais como a indústria, o mercado de filmes, o roteiro, o argumento, as locações, os atores, a produção, as interpretações, as conversas depois do filme, dentre outros.

Almeida (1994) considera a sala de projeção como o local de encontro entre as pessoas que produzem e as que o consomem o cinema. Para ele, trata-se do momento estético em que um objeto produzido técnica e artisticamente vai ao encontro do imaginário do espectador, 
criando uma relação íntima com seus desejos, ressentimentos, traumas, prazeres, suas vontades, ilusões, raivas e vivências. O autor lembra, ainda, que nossa objetividade só é restituída após o término da projeção.

Com o seu aparato tecnológico apropriado para documentar, registrar de forma estética e narrar histórias, o cinema nos permite uma nova maneira de olhar para o mundo e, com isso, estabelece uma forma peculiar de inteligibilidade e conhecimento. Esta arte pode ser utilizada, nas escolas - desde a educação infantil ao ensino superior- como um dispositivo didático lúdico e atrativo, valioso na formação de novas gerações, possibilitando o encontro simultâneo com a cultura cotidiana e erudita, pois é o campo no qual a estética, o entretenimento, a ideologia e os valores sociais mais amplos são sintetizados numa mesma obra.

Alguns estudiosos consideram o cinema como uma das artes mais completas do século XX, por sua capacidade de sintetizar diversas outras manifestações estéticas produzidas pelo ser humano: literatura, pintura, arquitetura, dentre outras.

Quanto mais o espectador de cinema se empenhar em compreender/analisar os filmes aos quais assiste, maiores serão as chances de se aproximar da intencionalidade e seleção de sentidos pretendidas pelos idealizadores, das características culturais e das ideologias de suas escolhas, permitindo compará-las a sua própria cultura e valores. Neste sentido, do relacionamento espectador-filme pode surgir uma consciência humano-social com capacidade de resignificar o audiovisual e ir além dele, num processo quase subliminar, propício à formação de novas percepções e entendimento da vida em sociedade.

Neste sentido, Trevizan (1998) aponta que o potencial artístico de um bom filme não se sustenta somente no reconhecimento da credibilidade da história contada, mas reside, sobretudo, na possibilidade de a linguagem criada estabelecer com o espectador um nível profundo de comunicação intelectual, filosófica, psicológica, emocional, fazendo com que ele reflita sobre si mesmo e sobre o outro.

\subsection{A sociedade submersa em imagens, sons e movimentos}

É inegável a presença das imagens, sons e movimentos em nosso cotidiano. Já é consenso entre vários estudiosos que o cinema não nasceu mudo, mas em meio a narradores, explicadores, conferencistas, conversas, cantorias, enfim, em uma grande intersemiose. Neste 
ponto, damos destaque à compreensão da importância do montador na construção dos sentidos em meio ao emaranhado de signos que compõem uma cena. $\mathrm{O}$ próprio cinema nos tornou mais conscientes disto, por exemplo, quando nos apresentou Elizaveta Svilova restaurando o tempo em $O$ homem com a câmera ${ }^{69}$ (VERTOV, 1929).

Atualmente, a produção e a circulação de imagens se dão de forma interativa e dinâmica, como aponta Di Camargo (2009):

Desde as tradicionais artes plásticas, passando pela fotografia, pelo cinema, pela TV e chegando à Internet, o homem tem utilizado diversos recursos para se comunicar através da imagem. E, analisando os contextos da produção imagética, percebe-se que as imagens estão ligadas à arte, ao jornalismo, à publicidade, enfim, aos vários campos de produção de sentido, como um elemento imprescindível para o processo de comunicação (p. 2728).

O audiovisual é a linguagem do principal meio ${ }^{70}$ de comunicação social e tem presença marcante na produção cultural contemporânea, o que pode ser observado desde a propaganda até a sofisticada produção cinematográfica contemporânea. São vários os gêneros que utilizam a linguagem audiovisual como ferramenta essencial: filmes, telenovelas, vídeos, minisséries e videoclipes, os quais estão cada vez mais presentes em nossa cultura e tecnologicamente mais sofisticados (DI CAMARGO, 2009).

É inegável a revolução causada pela Internet na produção e circulação da linguagem audiovisual. A teia de alcance mundial mudou nossa forma de acesso à informação; a maneira de concebê-la (de forma hipertextual e multimodal); nossa forma de entretenimento e o panorama educacional. Cabe destacar também que a internet possibilita ao usuário a possibilidade de desempenhar um papel ativo, de emissor criador de conteúdo audiovisual e não somente o tradicional consumidor de conteúdo. Diante da gama de possibilidades para criação e consumo de produtos audiovisuais, faz-se necessário sensibilizar o espectador para compreender os vários discursos presentes nos produtos culturais transmitidos pela mídia:

Principalmente [pela] televisão, objeto popular de consumo, canal ideal para a propagação da cultura de massa. E também o cinema, uma forma complexa de fazer arte que difere das tradicionais em diversos aspectos. Sem a intenção de fazer um julgamento preconceituoso, faz-se necessário realizar

\footnotetext{
${ }^{69} \mathrm{O}$ filme, rico em metalinguagem, apresenta um cinegrafista que viaja documentando cenas da União Soviética no começo do século 20, mostrando cenas urbanas, do cotidiano e da intimidade de seus cidadãos. Na obra, dois elementos da produção cinematográfica - câmera e montagem - são apresentados em perfeita sintonia, por meio de diversos recursos que só poderiam existir com atuais softwares, mas Vertov conseguiu fazer manualmente $\mathrm{e}$ com muita técnica e profissionalismo: câmera lenta, animação, imagens múltiplas, tela dividida, zoom in e zoom out, foco embaçado e imagens congeladas, dentre outros.

${ }^{70}$ Do latim medius, com plural em media, que nos remete à mídia.
} 
uma leitura mais crítica dessa linguagem cada vez mais sofisticada. É conveniente rever o modo como enxergamos a comunicação de massa, a fim de que possamos participar, de forma politizada, desse processo de produção e consumo (DI CAMARGO, 2009, p. 28).

Vários estudiosos destacam as potencialidades da sétima arte no processo educativo. Napolitano (2003), por exemplo, comenta que o trabalho com o cinema pode auxiliar a escola a reencontrar a cultura ao mesmo tempo cotidiana e elevada, pois o cinema é o campo no qual a estética, o lazer, a ideologia e os valores sociais mais amplos são sintetizados numa mesma obra de arte.

Neste sentido, Trevizan (1998) cita que o filme congrega informações nas diferentes áreas da experiência humana e por isso deve ser utilizado, nas escolas, com o um instrumento didático.

\subsection{Os vários usos do cinema e vídeo na escola}

Em artigo acerca do vídeo na sala de aula, Moran (1995, p. 27) destaca que este dispositivo auxilia o bom professor, atrai os alunos, mas não modifica substancialmente a relação pedagógica. O pesquisador argumenta que as mídias aproximam a sala de aula do cotidiano, das linguagens de aprendizagem e comunicação da sociedade urbana, mas também introduz novas questões no processo educacional.

$\mathrm{O}$ autor nos apresenta vários usos do vídeo em sala de aula. Como usos inadequados, temos o vídeo-tapa-buraco; vídeo-enrolação; vídeo-deslumbramento e o vídeo-perfeição. Como possibilidades desejáveis de utilização o pesquisador relaciona o vídeo como sensibilização, ilustração, simulação, conteúdo de ensino, produção, avaliação, espelho e interação/suporte de outras mídias. Comentaremos, a seguir, cada uma dessas categorias elencadas.

Para ele, o "vídeo-tapa-buraco" ocorre quando exibimos um vídeo para sanar um problema inesperado, como, por exemplo, a falta do professor. O autor argumenta que "usar este expediente eventualmente pode ser útil, mas se for feito com frequência desvaloriza o uso do vídeo e o associa - na cabeça do aluno - a não ter aula” (MORAN, 2003, p. 34).

O "vídeo-enrolação" aconteceria com a exibição de um vídeo sem muita relação com o conteúdo que está sendo estudado. Nesta situação, o alunado até pode não reclamar na hora e ser coautor do mau uso, mas sabe que o vídeo é usado como forma de camuflar a aula. 
Outra situação seria o "vídeo-deslumbramento", que ocorre quando o professor que acaba de descobrir o uso do vídeo se empolga e passa vídeo em todas as aulas, esquecendo outras dinâmicas mais pertinentes, neste caso, "o uso exagerado do vídeo diminui a sua eficácia e empobrece as aulas" (MORAN, 2003, p. 34).

Situações negativas causadas pelo professor que sempre questiona todos os vídeos possíveis, apresentado defeitos de informação ou estéticos, são consideradas pelo autor de "vídeo perfeição". Segundo ele, as obras sempre serão representações e, no caso dos "vídeos que apresentam conceitos problemáticos podem ser usados para descobri-los, junto com os alunos, e questioná-los" (MORAN, 2003, p. 34).

Outra forma indesejada de utilização consiste no "só vídeo", quando o professor não explora o material, ficando na mera exibição, sem discussão e nem integração com outros assuntos da aula.

Dentre as propostas desejáveis de utilização, o autor apresenta o "vídeo como sensibilização", como um dos mais importantes na escola: "um bom vídeo é interessantíssimo para introduzir um novo assunto, para despertar a curiosidade, a motivação para novos temas. Isso facilitará o desejo de pesquisa nos alunos para aprofundar o assunto do vídeo e da matéria" (MORAN, 2003, p. 34).

O "vídeo como ilustração" tem o potencial de reunir muitos contextos, na maioria das vezes distantes da realidade do aluno, em uma só mídia e permite exemplificar e/ou complementar o que é visto em sala de aula, auxiliando os alunos na compreensão de cenários desconhecidos, de outros tempos históricos. Neste sentido, "a vida se aproxima da escola através do vídeo" (MORAN, 2003, p. 35). O pesquisador argumenta que um vídeo pode trazer para a sala de aula realidades distantes dos alunos, como, por exemplo, a Amazônia ou a África.

O cinema pode ser utilizado em atividades que visem desmistificar conceitos cristalizados acerca da língua e cultura estrangeira que está sendo estudada, como no caso do espanhol, pois permite apresentar diversas realidades e variedades linguísticas e culturais num mesmo contexto, isto é, na sala de aula, de maneira a permitir o trabalho com as crenças e a desconstrução de estereótipos negativos.

Neste sentido, o cinema pode ser um material didático, definido pelas Orientações Curriculares para o Ensino Médio - Espanhol, como o conjunto de recursos dos quais os professores se valem em suas práticas pedagógicas, “entre os quais se destacam, grosso modo, 
os livros didáticos, os textos, os vídeos, as gravações sonoras (de textos, canções), os materiais auxiliares ou de apoio, como gramáticas, dicionários, entre outros" (OCEM, 2008, p. 154) que exercem um papel importante na sala de aula.

A utilização do cinema como recurso didático pode propiciar momentos de encontro com o Outro, sua língua e sua cultura, e mostrar aos alunos realidades muitas vezes desconhecidas e distantes, tornando o aprendizado mais significativo e prazeroso.

Neste sentido, já é sabido que para que o ensino de uma língua seja mais eficaz é necessário não só aprender gramática, mas ir além da simples sensibilização do aluno quanto a questões socioculturais, como afirma Goettenauer (2005):

A questão não é apenas sensibilizar o aluno e buscar formas para ensejar atitudes imparciais diante de outros valores, outras tradições, outros modos de ver, viver, e nomear a realidade. Trata-se de algo bem mais complexo: acolher o outro e compartilhar com ele hábitos, costumes, ideias (...). Apropriar-se de uma língua distinta da materna é apropriar-se de novas lentes para mirar o mundo (p. 64).

Outra rica possibilidade é o "vídeo como simulação" já que nos permite ilustrar a aula de forma mais sofisticada, por exemplo, "o vídeo pode simular experiências de química que seriam perigosas em laboratório ou que exigiriam muito tempo e muitos recursos. Um vídeo pode mostrar o crescimento acelerado de uma planta, de uma árvore - da semente até a maturidade - em poucos segundos" (MORAN, 2003, p. 35).

O "vídeo como conteúdo de ensino", parte do pressuposto de que a mídia pode abordar temas direta ou indiretamente. Ao apresentar o "vídeo como produção", o autor subdivide esta categoria em três itens: a) como documentação, registro de eventos, aulas, estudos do meio, experiências, entrevistas, depoimentos; b) Como intervenção: interferir, modificar um determinado programa, um material audiovisual, acrescentando uma trilha sonora ou editando o material de forma compacta ou introduzindo novas cenas com novos significados, "assim como ele interfere num texto escrito, modificando-o, acrescentando novos dados, novas interpretações, contextos mais próximos do aluno" (MORAN, 2003, p. 35); c) como expressão, como nova forma de comunicação, adaptada à sensibilidade principalmente das crianças e dos jovens:

As crianças adoram fazer vídeo e a escola precisa incentivar ao máximo a produção de pesquisas em vídeo pelos alunos. A produção em vídeo tem uma dimensão moderna, lúdica. Moderna como um meio contemporâneo, nova e que integra linguagens. Lúdica, pela miniaturização da câmera, que permite brincar com a realidade, levá-la junto para qualquer lugar. Filmar é uma das experiências mais envolventes tanto para as crianças como para os 
adultos. Os alunos podem ser incentivados a produzir dentro de uma determinada matéria, ou dentro de um trabalho interdisciplinar. E também produzir programas informativos, feitos por eles mesmos e colocá-los em lugares visíveis dentro da escola e em horários em que muitas crianças possam assistir a eles (MORAN, 2003, p. 36).

Outra proposta seria a do "vídeo como avaliação", o que inclui os alunos, o professor, e o processo de ensino-aprendizagem. O autor destaca também o "vídeo-espelho"; nele, "vejo-me na tela para poder compreender-me, para descobrir meu corpo, meus gestos, meus cacoetes" (MORAN, 2003, p. 36). Esta categoria permite a análise do grupo e dos papéis de cada um, para acompanhar o comportamento individual, do ponto de vista participativo, para incentivar os mais retraídos e pedir aos que falam muito para darem mais espaço aos colegas. O autor argumenta também que o vídeo-espelho é de grande utilidade para o professor se ver, examinar sua comunicação com os alunos, suas qualidades e defeitos.

A última possibilidade apresentada seria a do "vídeo como interação/suporte de outras mídias"; nela o autor destaca o vídeo como suporte da televisão e do cinema e a interação do vídeo com outras mídias, como o computador, celular, videogames, internet.

\subsection{Pesquisa em educação com base nas artes}

Neste momento, compartilharemos das ideias de Moraes (2004, p. 53), para quem os filmes, além de um recurso para a prática educacional, na medida em que os utilizamos em sala de aula, podem ser objetos de pesquisa nos quais buscamos entender as várias lentes que se cruzam na representação da cultura escolar.

Dessa forma, é possível ir além da exploração da sétima arte como recurso para a prática educacional, partindo para o texto fílmico como objeto de pesquisa para a compreensão de como a cultura escolar é representada pelo cinema, isto é, como as funções, objetivos, práticas e agentes escolares são veiculados por esta mídia.

Levando-se em consideração que a linguagem cinematográfica estabelece com o espectador uma comunicação intelectual, filosófica, psicológica e emocional, fazendo com que ele reflita sobre si mesmo e sobre o outro, é possível analisar os diversos recursos da linguagem cinematográfica utilizados pelos cineastas e como essas opções estéticas influenciam na construção do olhar do espectador sobre a realidade escolar, bem como a escola é representada pela sétima arte. Isto é, como as produções cinematográficas colaboram na construção de referência do imaginário a respeito do ambiente escolar. 
Propostas neste sentido se inserem no campo da Pesquisa Educacional com base nas Artes $^{71}$, via pesquisa qualitativa de cunho interpretativista que, concebendo o cinema como prática social e a partir da teoria da representação cultural, pretende compreender as vozes engendradas pela linguagem cinematográfica para compor as narrativas fílmicas nas quais é retratada a cultura escolar.

Embora o trabalho dos artistas seja sempre considerado da perspectiva ampla da criatividade, vários artistas contemporâneos se empenham na realização de formas altamente sistemáticas e profundas de pesquisa... Ao prepararem um espetáculo teatral, por exemplo, diretores, dramaturgos e atores frequentemente realizam uma ampla investigação da linguagem e dos costumes daquele período ou mesmo a história das produções daquele determinado trabalho (...). Compositores e artistas performáticos pesquisam, coletam histórias orais e se empenham em estudos etnográficos sem dar nomes ao que fazem (SABATINI, 1993 apud TELLES, 2004, p. 35).

Telles (2006) relata que um dos pioneiros a citar o potencial das artes para buscar instrumentos e formas alternativas de representação das pesquisas em educação foi Eisner (1991). Para esse educador, as artes têm uma longa tradição em descrever, interpretar e avaliar o mundo e dar forma à experiência.

Exemplos de experiências vicárias são encontrados nas artes. Por meio da forma artística de pesquisa conhecida como narrativas de histórias educacionais, o leitor pode experienciar, de forma vicária, um mundo virtual crível da escola ou sala de aula, habitado por pessoas que são as personagens virtuais da história. Este tipo de experiência estética pode ser suficientemente significativa a ponto de causar um questionamento das premissas fundamentais dos valores, assim como das bases ideológicas sobre as quais as decisões relativas à educação são tomadas (DENZIN, 1992, p. $15)$.

Nesta perspectiva do cinema como fonte de pesquisa para a compreensão das possíveis representações da cultura escolar, cabe citar Pinheiro (2010), Fabris (2005) e as pesquisas de Telles $(2004,2005)$.

A dissertação de mestrado de Pinheiro (2010) verifica as representações sociais relacionadas à escola a partir da comparação das imagens levadas à tela pela produção francesa Os incompreendidos (1959) e pelo filme chileno Machuca (2004).

Outro trabalho nesta linha com o qual tivemos contato é a tese de Fabris (2005). Nela, a autora toma o cinema como objeto de compreensão da cultura escolar e analisa como o

\footnotetext{
${ }^{71}$ Arts-Based Educational Research (EISNER, 1991, 1997; DIAMOND \& MULLEN, 1999; TELLES, 2004 e 2005), Artsinformed Research ou Arts-Based Approaches to Qualitative Inquiry (GRAY, 2003).
} 
cinema brasileiro representa a escola e o trabalho docente no contexto de dezessete filmes nacionais.

Telles (2004) utiliza o espetáculo teatral como dispositivo de reflexão e representação do desenvolvimento do professor e tece reflexões acerca da pesquisa educacional com base nas artes e na reflexão compartilhada, defendendo a necessidade de formas alternativas de representação da docência e do conhecimento dos professores.

\subsection{Contribuições da prática cineclubista para a formação humana}

Conforme cita Andrade (2010, p. 212), “o [sistema] cineclubista é aquele que se dedica a divulgar e discutir o cinema como obra de arte, como pensamento, como renovação do olhar, do pensar e do sentir. E não como consumo, pura e simplesmente". Macedo (2005, p. 29) apresenta-nos três características dos cineclubes: i) não ter fins lucrativos; ii) possuir uma estrutura democrática; iii) ter um compromisso cultural e ético.

Segundo o autor, os primeiros cineclubes apareceram como uma resposta quase que automática ao excesso de estandardização que o monopólio do cinema ia instaurando. Os coletivos se agruparam cheios de ilusões sobre a "sétima arte" e o papel do "belo". No entanto, mesmo assim, eles já surgiram como uma organização sem fins lucrativos - o que os diferenciava dos valores de mercado -, já nasceram baseados numa estrutura coletiva e democrática (em maior ou menor grau, mas sempre democrática) e se formaram com uma comprovada disposição de se contrapor ao poder monopolizado e alienador do cinema comercial, ressaltando as produções que não encontravam distribuição no mercado comercial ou que eram repelidas por motivos estéticos, políticos. Dessa forma, os cineclubes afloraram como uma maneira de organização coletiva.

Além de permitir ao homem sedentário, que incialmente era nômade, a viagem da alma sem que o corpo saia do lugar o cinema também teve, em seu início um caráter de nomadismo que ainda hoje permanece em algumas regiões do Brasil. Neste sentido, podemos destacar que as primeiras sessões de cinema realizadas no Brasil cumpriam essa função de movimentação simbólica, além de terem um caráter itinerante pela própria limitação técnica.

Atualmente, ocorre no Brasil um grande número de sessões semelhantes a essas primeiras por seu caráter nômade, itinerante, e arcaicamente comunitário. Elas reúnem espectadores em centros comunitários, quadras de esporte, ruas de bairros periféricos, hospitais, presídios, praças interioranas. A falta de salas específicas e adequadas para a exibição cinematográfica colabora em muito para que essa situação se dê. Segundo a Pesquisa de 
Informações Básicas Municipais do IBGE - Instituto Brasileiro de Geografia e Estatística, 92 por cento das cidades brasileiras não possuíam salas de cinema até 1999 (SILVA, 2006, p. 228).

A pesquisadora relata que as sessões comunitárias existentes até hoje não se dão unicamente pela falta de salas de projeção, mas pela necessidade de socialização do ser humano, já que "ver produtos da indústria cultural numa tela de cinema é participar afetivamente de um movimento lúdico que remete constantemente ao outro e, reflexivamente, a si mesmo (SILVA, 2006, p.229)".

A familiaridade e a vinculação institucional com o local de projeção conferem ao espaço da sessão comunitária uma significação diferente daquela atribuída à sala de cinema comercial. A movimentação das pessoas se dá de maneira mais fluida, aparentemente mais descontraída e festiva. O conhecimento dos espectadores entre si e com os organizadores do evento também modifica a qualidade da interação. Os indivíduos são reconhecidos como tal e isso diminui a formalidade dos procedimentos de aproximação, facilitando o encontro. Outros comportamentos típicos do anonimato (pôr os pês sobre o espaldar da cadeira da frente ou jogar lixo no chão) são inibidos. Ainda que seja assim, qualquer tipo de filme ou de sessão de cinema alimenta produções simbólicas e relações sociais que se estabelecem em torno do filme. Quando essas relações envolvem vínculos comunitários mais caracterizados, a mobilização do público é muito intensa, excede o evento (SILVA, 2006, p.229).

Alves (2010) apresenta-nos a formação humana como um problema crucial do nosso tempo histórico; para ele "uma democracia sem democratização radical é o anseio oculto do capitalismo histórico" (p. 13). Neste sentido, o autor apresenta como característica a constituição do capitalismo manipulatório, "que se tornou hoje um sistema mundial organizado pela oligarquia industrial-financeira, que controla os aparatos de 'formação de opinião pública', sob o controle do capital concentrado dos grandes grupos da indústria cultural” (p. 13).

Diante da formação humana como um problema crucial do nosso tempo histórico, acreditamos que a prática cineclubista, principalmente em ambientes educacionais, pode colaborar para a promoção de uma formação integral e plena, já que, infelizmente, $90 \%$ das cidades brasileiras não têm sala de cinema, torna-se fundamental promover novas formas de acesso e difusão cultural:

No Brasil, para ficarmos exclusivamente no campo do audiovisual, apenas cerca de $10 \%$ dos municípios tem salas de cinema, e é esse também o percentual de brasileiros que vê algum filme no cinema pelo menos uma vez por ano. Se todos têm televisores, o acesso a programações diferenciadas 
(TV por assinatura), é da mesma magnitude que o cinema. $\mathrm{O}$ acesso regular à internet tem crescido muito, mas ainda é privilégio de uma minoria. A quase totalidade das comunidades brasileiras não tem museus, teatros, bibliotecas, etc. No resto da América Latina, África e grande parte da Ásia onde se concentram $80 \%$ da população mundial- os indicadores são semelhantes, frequentemente piores (MACEDO, 2010, p. 33).

Dito de outra maneira, o autor destaca que mais de $90 \%$ dos municípios brasileiros não têm cinema e o mesmo percentual de exclusão se aplica ao público, já que menos de $10 \%$ da população do Brasil vai ao cinema pelo menos uma vez por ano. Macedo (2005) argumenta que o cinema ao qual um décimo da população brasileira tem acesso é o cinema "produzido no famoso distrito da cidade de Los Angeles, Hollywood, onde se concentra a indústria que controla $85 \%$ dos mercados cinematográficos de todo o mundo" (p. 4):

Esse 'produto' ocupa, de forma predatória, todo o espaço cultural, procurando substituir o imaginário do nosso povo, sufocado qualquer outra expressão e matando toda diversidade. Pois dentre esses $10 \%$ da população que vão [sic] ao cinema, são cerca de $10 \%$ os que veem um filme brasileiro ou de outra nacionalidade, inclusive os filmes americanos não produzidos pelas grandes corporações hollywoodianas. Em outras palavras, só 1\% dos brasileiros têm algum contato com filmes brasileiros e de todo o resto do mundo, somados (MACEDO, 2005, p.5).

Ao argumentar acerca da potencialidade dos cineclubes em espaços escolares, Alves (2010, p. 13) ressalta que, na medida em que a prática cineclubista conseguir elaborar metodologias pedagógicas capazes de irem além da mera exibição do filme e, inclusive, de mera discussão entretida da narrativa fílmica, ela se coloca num campo precioso da subversão cultural contra a ordem "imbecilizante" do capital. Neste sentido, devemos ter como meta, ir além da tela no sentido de criar, por meio da prática cineclubista, espaços de produção de conhecimento crítico.

Vivemos, de fato, uma total massificação de valores [...]. É preciso mostrarmos a alma humana destituída de fórmulas convencionalizadas, de estereótipos. É necessário que o homem redescubra o seu próprio significado diante do mundo codificado que se lhe apresenta (TREVIZAN, 1998, p. 96).

Diante da importância de promover o trabalho com o cinema em contextos de formação, compartilharemos da experiência de dois planos de trabalho que propõem a prática cineclubista em Monteiro-PB, cidade do cariri ocidental paraibano que, assim como $90 \%$ das cidades brasileiras, não tem sala de cinema.

No Campus VI da Universidade Estadual da Paraíba-UEPB, o Núcleo de Espanhol desenvolve semanalmente o "Cinema dos outros", que visa a exibição e discussão de filmes 
do universo hispânico, com vistas à alteridade e à interculturalidade. O projeto "cinema como arte, entretenimento, ferramenta e prática social" que lideramos tem três focos de atuação: i) complementar e fortalecer a prática cineclubista: exibição, análise e discussão no campus; ii) constituir um grupo interdisciplinar de estudos e pesquisas sobre o cinema; iii) desenvolver oficinas para produção de material didático e formação de multiplicadores na aquisição do ELE mediada pelo cinema.

Macedo (2005, p. 20) relata que $60 \%$ dos jovens entre 15 e 29 anos nunca foram ao cinema. No caso do nosso contexto de pesquisa, uma coleta de dados feita com os alunos do curso de Letras-Espanhol do Campus VI revela que 59\% deles nunca foram ao cinema. Um total de $42 \%$ dos participantes declarou que raramente assiste a filmes, em casa ou com amigos. Esses dados revelam que o nosso público não tem o costume de consumir/apreciar o cinema.

\subsection{Algumas pesquisas que utilizam o cinema no ensino de línguas e na formação de professores}

No que concerne às pesquisas que utilizam o cinema como mediador no ensino de línguas, tivemos contato com as investigações de Garcia de Stefani (2010) e Gómez Alibés (2008). No campo da formação inicial e continuada de professores de línguas, conhecemos os trabalhos de Mayrink (2007) e Garcia de Stefani (2014).

Garcia de Stefani (2010) desenvolveu uma pesquisa de mestrado na qual argumenta que embora o cinema possa configurar-se como um recurso didático eficiente para a implementação do ensino comunicativo de línguas, por seu caráter lúdico e por sua capacidade de promover maior envolvimento dos alunos na realização de atividades significativas, percebe-se que seu uso ainda é bastante limitado no âmbito de ensino de língua estrangeira.

A partir desta constatação, o objetivo da pesquisa qualitativa de base etnográfica desenvolvida pela pesquisadora foi investigar o uso do filme Diários de Motocicleta como conteúdo didático no contexto de ensino de espanhol como língua estrangeira, tomando por base os pressupostos teóricos da aprendizagem significativa. A pesquisadora argumenta que a análise dos dados revela que o filme representa uma maneira eficaz de apresentar o insumo linguístico contextualizado, de envolver os alunos em atividades de interação e negociação de 
sentidos, de estimular o pensamento crítico e o conhecimento de mundo, além de contribuir significativamente para o desenvolvimento da autonomia do aluno como aprendente de línguas.

Gómez Alibés (2008) propõe a substituição das tradicionais gravações de áudio dos livros didáticos por fragmentos de filmes como uma nova visão da apresentação de situações cotidianas na aula de E-LE.

O autor argumenta que há uma série de situações típicas pelas quais qualquer pessoa pode passar vivendo em um país estrangeiro que a maioria dos livros didáticos de E-LE, geralmente, apresentam em suporte de áudio, dentre elas: fazer pedidos em um restaurante, perguntar o caminho para um pedestre, registrar um boletim de ocorrência em uma delegacia, realizar operações bancárias, resolver problemas no aeroporto, se expressar em um consulta médica, alugar um imóvel, interagir em uma entrevista de emprego, fazer uma reserva em um hotel.

O pesquisador conclui ser possível substituir esses arquivos de áudio tradicionais por trechos de filmes que apresentam usos diários e reais da linguagem de forma autêntica e próxima da realidade.

Em sua pesquisa de doutorado, Mayrink (2007) lançou mão de produções cinematográficas com o objetivo descrever e interpretar o fenômeno da formação críticoreflexiva de professores em formação inicial (alunos de Letras e Pedagogia) mediada por filmes. A partir da perspectiva sociocultural de Vigotski, a autora compreendeu que os filmes se constituem em signos mediadores com potencial para o desenvolvimento crítico-reflexivo do futuro professor.

Atualmente, Garcia de Stefani (2014) realiza sua pesquisa de doutorado tendo como temática a formação continuada de professores de inglês e espanhol em serviço com o apoio do cinema, com vistas a fomentar o desenvolvimento e a aplicação em sala de aula de atividades didáticas a partir conteúdo fílmico à luz dos letramentos críticos.

\subsection{O papel dos meios alternativos na difusão e no acesso aos produtos audiovisuais}

Macedo (2005) destaca o papel da internet no acesso e difusão do audiovisual e as novas alternativas e suportes para a prática cineclubista que as tecnologias da informação e comunicação possibilitam. 
O cinema digital e a rede mundial de computadores representam um instrumento decisivo na evolução do processo de distribuição e difusão. Neste sentido, temos os meios alternativos - assunto polêmico - como um importante elemento da democratização do acesso e da formação do público.

A principal realização da digitalização é que inúmeros filmes de todas as partes do mundo, de todas as épocas e de todos os géneros cheguem com boa qualidade e a preços que são acessíveis para milhões de latino-americanos. Com efeito, a comercialização informal de filmes em DVD - chamado de "pirataria" pelas grandes empresas e a mídia - beneficiou, principalmente, milhões de conterrâneos que não têm uma sala de cinema nas proximidades, ou que não podem arcar com os proibitivos preços das entradas - uma ida familiar ao cinema equivale, aproximadamente, a 10 por cento do salário mínimo nos diversos países da América Latina-. Assim, inúmeros lares podem ver a estreia "top" que a mídia constrói como necessidade inevitável ou, virtualmente, qualquer filme que eles desejarem ${ }^{72}$ (GONZÁLEZ, 2011, p. 27).

Neste sentido, o autor destaca também o papel de inciativas privadas que surgem nos setores populares para suprir essa carência por circuitos acessíveis de exibição. Como exemplo, o pesquisador cita a experiência da Bolívia, há mais de 20 anos, com os "videoapis", denominados como "locales de comida al paso (ubicados en barrios de sectores de bajos recursos) que adosaron televisores de pantalla grande y reproductores de video-home para ofrecer 'programaciones' variadas de películas de todo el mundo y de todos los géneros por pocas monedas" (GONZÁLEZ, 2011, p. 27).

A partir da facilidade com que as novas tecnologias permitem realizar cópias de alta qualidade de material audiovisual (com mínimo equipamento) e ter acesso às mesmas -seja mediante a venda nas ruas dessas cópias, ou baixando-as da Internet, usando os programas "peer to peer $^{73}$ "-, são criadas as ferramentas para que o público excluído do mercado cultural (em especial, as classes média baixa e baixa) opere uma espécie de "acesso cultural por mão própria", seja mediante a compra nas ruas de discos compactos copiados e o intercâmbio digital de arquivos sem fins lucrativos

\footnotetext{
${ }^{72}$ No original: "El principal logro de la digitalización es que innumerables filmes de todo el mundo, de todas las épocas y de todos los géneros lleguen con buena calidad y a precios accesibles a millones de latinoamericanos. En efecto, la comercialización informal de películas en DVD -llamada "piratería” por las grandes empresas y los medios- ha beneficiado, principalmente, a millones de conterráneos que no tienen una sala de cine cercana, o que no pueden pagar los prohibitivos precios de las entradas - una salida familiar al cine equivale, aproximadamente, al 10 por ciento del salario mínimo en los distintos países de América Latina-. Así, innumerables hogares pueden ver el estreno "top" que los medios construyen como necesidad ineludible o, virtualmente, cualquier película que deseen”.

${ }^{73}$ Peer-to-peer (par-a-par/ponto-a-ponto, sigla: P2P) é uma arquitetura de redes de computadores em cada um dos pontos da rede funciona tanto como cliente quanto como servidor, permitindo compartilhamentos de serviços e dados sem a necessidade de um servidor central (Wikipedia).
} 
(via Internet, usando os programas "peer to peer") ${ }^{74}$ (GONZÁLEZ, 2011, p. 34).

O pesquisador cita, nas regiões com menos recursos, o papel de estabelecimentos comerciais, como papelarias, lan houses ou os ciber cafés, que oferecem computadores com acesso à internet em que as pessoas podem pagar valores acessíveis, geralmente, por hora de utilização. O autor apresenta esses lugares como centro de socialização (pessoal e virtual) e de acesso e difusão do conhecimento, da educação e da cultura de milhões de pessoas, principalmente jovens, que - em sua maioria - nunca foram ao cinema, não visitam bibliotecas, abandonaram a escola e se encontram em situação de risco social. Nesses espaços, as atividades mais praticadas são o consumo de música e filmes baixados da internet, para assistir e/ou copiar e/ou compartilhar.

\subsection{O exercício da competência intertextual}

Já é consenso entre os estudiosos que quanto mais o espectador de cinema se empenhar em compreender/analisar os filmes aos quais assiste, maiores serão as chances de se aproximar da intencionalidade e seleção de sentidos pretendidas pelos idealizadores, das características culturais e das ideologias de suas escolhas, permitindo compará-las a sua própria cultura e valores. Dito de outra maneira, se no decorrer da história do cinema aconteceram mudanças importantes, tanto no modo de fazê-lo como no de recebê-lo, um fato não deve ser desconsiderado: quanto maior o empenho do espectador em perscrutar as obras a que assiste, mais chances ele terá de se aproximar das intenções e buscas de sentido pretendidas por seus diretores, das características culturais e das ideologias que endossam suas escolhas, permitindo àquele compará-las a sua própria cultura e valores ideológicos, tornando-se, a cada filme assistido, um cidadão mais crítico e participativo na sociedade em que vive (TOLEDO \& DI CAMARGO, 2007, p. 110-111).

O espectador deve, portanto, preocupar-se com a identificação da correspondência estabelecida pelo produtor entre o sistema semiótico construído (linguagem) e a informação e/ou história transmitida. Para tanto, é preciso atenção especial ao processo de transformação dos elementos selecionados (sons, cores, formas, movimentos, gestos...) em signos

\footnotetext{
${ }^{74}$ No original: "A partir de la facilidad con que las nuevas tecnologías permiten realizar copias de alta calidad de material audiovisual (con mínimo equipamiento) y tener acceso a las mismas -ya sea a través de la venta callejera de dichas copias, o bajándolas de Internet, mediante los programas peer to peer-, se crean las herramientas para que el público excluido del mercado cultural (en especial, las clases mediabaja y baja) opere una especie de "acceso cultural por mano propia", mediante la compra callejera de discos compactos copiados y el intercambio digital de archivos sin fines de lucro (vía internet, mediante programas peer to peer".
} 
correlacionados com o todo organizacional da produção [...]. Podemos dizer que o espectador deverá agir da seguinte forma no percurso recepcional do filme: realizar a contemplação inicial dos elementos selecionados (estado primeiro de reconhecimento dos ícones); passar à inserção (relacional) destes elementos contemplados na totalidade significativa da produção fílmica (estado segundo de apreensão dos índices); alcançar a interpretação propriamente dita, atualizando convenções semióticas, leis pré-estabelecidas (estado terceiro de leitura final dos símbolos instaurados) (TREVIZAN, 1998, p. 98-99).

Neste sentido, Trevizan (1998, p. 86) aponta que o potencial artístico de um bom filme não se sustenta somente no reconhecimento da credibilidade da história contada, mas reside, sobretudo, na possibilidade de a linguagem criada estabelecer com o espectador um nível profundo de comunicação intelectual, filosófica, psicológica, emocional, fazendo com que ele reflita sobre si mesmo e sobre o outro.

O cinema é e sempre será um jogo de arte, humanismo e sedução. Todo bom filme apresenta uma adequação perfeita entre o conteúdo (a história humana contada) e a linguagem fílmica, veiculadora deste conteúdo [...] Todo filme repousa, é claro, sobre uma história, com personagens e situações aproximadas do mundo real [...]. A complexa estratégia de sedução da linguagem fílmica aguarda o espectador como um observador capaz de compactuar com o cineasta, na busca de um grau elevado de conhecimento filosófico sobre o próprio EU e sobre o OUTRO (o mundo). Uma obra de arte, através de uma linguagem particular, põe em questão as verdades sociais adquiridas, convidando o espectador a uma nova visão do mundo (TREVIZAN, 1998, p. 85-86).

A recuperação do diálogo entre textos diversos, tomando aqui texto no sentido amplo, enriquece a competência intertextual, o que permite que o espectador recupere experiências e leituras anteriores. Mikhail Bakhtin valoriza a interação entre os textos, isto é, o dialogismo do discurso: "a presença de muitas vozes que não se fundem em uma consciência única, mas participam de um dinamismo dialógico" (DI CAMARGO, 2009, p. 32).

O cinema representa uma instância privilegiada de relações dialógicas e intertextuais, de construção ideológica e interação social, devido ao interrelacionamento das mais variadas modalidades de signos sistematizados, não apenas pela palavra, mas, igualmente, pelo som e pela imagem- na constituição de seu produto final, o texto fílmico (DI CAMARGO, 2009, p. 46).

Todo texto é sempre resultado da uma rede complexa de discursos porque todo sujeito criador está sempre em sintonia cultural com o seu tempo histórico e em sua produção recupera outras experiências de leitura (TREVIZAN, 1998). Para o professor, proporcionar ao 
aprendiz oportunidades para desvendar a pluralidade contida em um filme pode acrescentar muito ao desenvolvimento global enquanto indivíduo:

a importância da exploração em sala de aula, da natureza intertextual do texto fílmico. Assim, como o texto literário, também o texto fílmico é construído pelo processo dialogante com outros textos. Escritores, pintores, cineastas, artistas em geral dialogam culturalmente, resgatando, nos textos produzidos, o tesouro enciclopédico do já dito (ECO, 1991:22). É possível, portanto, em sala de aula, recuperarmos o diálogo de um filme em análise com outros filmes e também com textos estranhos ao universo cinematográfico (TREVIZAN, 1998, p. 91).

Levar o cinema para a sala de aula pode implicar proporcionar aos aprendentes ${ }^{75}$ um trabalho interdisciplinar que pode ir desde o resgate da história da sétima arte, por exemplo, até o desenvolvimento de conceitos da linguagem cinematográfica que propiciem elementos básicos de análise que permitam ler além das imagens. Dentro da diversidade de obras disponíveis, pode-se trabalhar, com as devidas adaptações, desde dança, música, teatro, literatura, culinária até oficinas para os alunos produzirem seus vídeos.

Neste sentido, compartilharemos aqui duas pesquisas das quais participamos e que abordam o exercício da intertextualidade. O trabalho de Souza et. all. (2007) relata uma investigação desenvolvida com alunos do $5 .^{\circ}$ ano do ensino fundamental de uma escola pública do interior paulista. $\mathrm{Na}$ ocasião, tivemos como objetivo principal compreender o ponto de vista dos alunos acerca da percepção da intertextualidade entre os clássicos da literatura infantil (Branca de Neve e os setes anões, Cinderela e A Bela Adormecida) e o filme Shrek(2001).

A experiência envolveu a leitura e dramatização dos clássicos, seguida pela comparação dos contos infantis e da análise dos elementos que constituem o gênero. $\mathrm{Na}$ sequência, houve a projeção do filme e o levantamento das relações entre o filme e as histórias. Na ocasião, verificou-se a recuperação do diálogo entre o filme com os contos trabalhados, bem como a relação entre as questões tratadas e a realidade dos alunos envolvidos.

Em Souza \& Bongestab (2012) mostramos que, ao tomar o cinema como arte e entretenimento, também existe a possibilidade de significá-lo como ferramenta e prática social propícios para o exercício da intertextualidade. Nele, exploramos a presença das

\footnotetext{
${ }^{75}$ Termo utilizado por Shulman (1986) apud Brzezinski (2002, p.2) para designar aquele ser que aprende como autor de sua própria aprendizagem.
} 
"muitas vozes" que compõem a produção cinematográfica de Carlos Saura, um diretor de cinema e escritor multifacetado, que entrelaça literatura, pintura, dança, música, fotografia, teatro, em suas obras.

\subsection{O potencial do cinema como mediador no trabalho com os gêneros orais na aula de E-LE}

Segundo Bakhtin (1999), em todas as atividades comunicativas são usados eventos textuais maleáveis, dinâmicos e plásticos, tanto orais quanto escritos, adaptáveis às formas de comunicação que surgem na sociedade, de forma que novas formas discursivas originam novos gêneros que, por vezes, são baseados em outros já existentes, fenômeno como transmutação, isto é, novas formas são ancoradas em modelos já existentes.

O processo de transmutação favorece a diluição das fronteiras entre oralidade e escrita. Nesta perspectiva, podemos afirmar que a língua se realiza em gêneros que se manifestam em vários domínios discursivos. Para Marcuschi (2008), os gêneros estão diretamente atrelados à noção de domínio discursivo, que se refere "à instância de produção discursiva" na qual o gênero está inserido. Desse modo, cada gênero faz parte de uma esfera mais ampla que acolhe vários outros gêneros. De acordo com o autor, "estes domínios nem são textos nem discursos, mas propiciam o surgimento de discursos bastante específicos" (p. 171).

$\mathrm{O}$ autor apresenta os gêneros como sendo os diversos textos que permeiam nossas relações sociais e que são definidos pelo conteúdo, estilo, função e composição. Isso implica dizer que os textos que produzimos não são estruturas linguísticas estanques, ou seja, modelos prontos e acabados, mas sim, produções sociais dinâmicas e flexíveis, que são feitas por alguém e para alguém, com alguma finalidade e em um contexto sócio-histórico-cultural definido.

A ideia de que o ensino de língua deve servir para tornar o aluno comunicativamente ativo na língua-alvo exige o contato dos aprendizes com a maior quantidade possível de gêneros discursivos na língua a ser aprendida, pelo fato de esse conhecimento ser necessário para a compreensão linguística e cultural, bem como para que ele possa produzi-los na línguaalvo. Para isso, é preciso que o professor estimule o conhecimento dos alunos em relação aos fatores extralinguísticos. 
Neste sentido, o cinema apresenta diversos gêneros orais (música, poema, fala cotidiana...) em um mesmo suporte e, a partir das temáticas apresentadas, nos permite trabalhar com diversos gêneros escritos. Em outras palavras, o cinema como input nos apresenta insumos para trabalhar todas as habilidades, nesta tese entendidas como simultâneas e integradas, já que não é possível apresentar uma hierarquia entre elas:

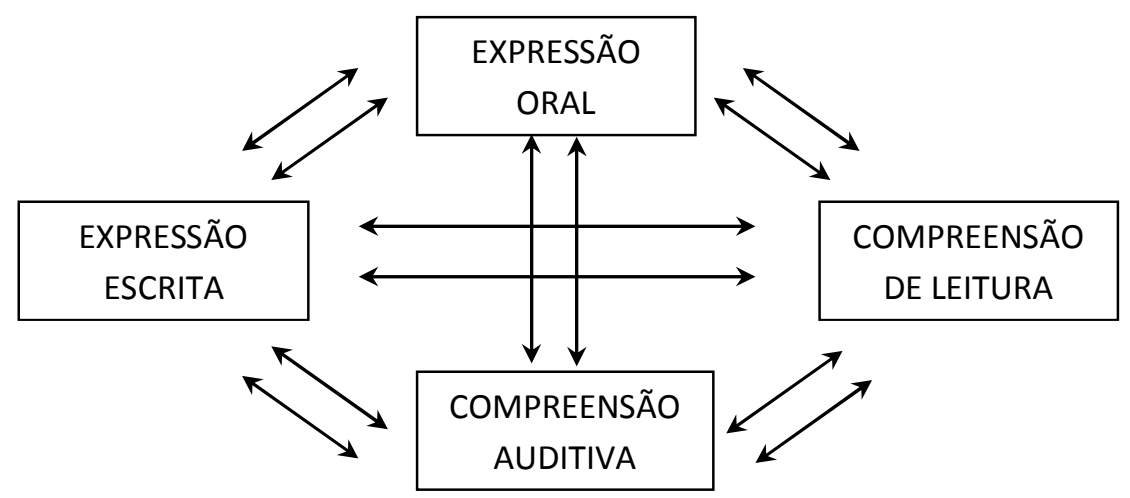

Quadro 11: As quatro habilidades - simultâneas e integradas. Fonte: Pinilla Gómez (2005, p. 882).

Qualquer uma dessas habilidades - ouvir, falar, ler, escrever - pode ser propulsora ou consequência das demais:

As habilidades geralmente não aparecem de forma isolada nas atividades, mas quase sempre respondem a esse princípio de integração em uma mesma atividade. Na maioria dos casos aparecem de forma simultânea ( ... ). Não necessariamente a uma habilidade de compreensão auditiva segue uma de expressão oral, ou a uma atividade de compreensão de leitura segue uma de expressão escrita, mas existe uma ampla variedade de possíveis combinações entre as quatro habilidades, sem que seja possível estabelecer uma ordem definida, já que cada habilidade pode ser propulsora ou consequência de qualquer uma das outras três ${ }^{76}$ (PINILLA GÓMEZ, 2005, p. 882).

É consenso entre vários professores e pesquisadores que, das quatro habilidades, a expressão oral é a mais difícil de ser alcançada, constituindo-se, talvez, no maior desafio, tanto para o professor quanto para o estudante. Dentre as quatro habilidades consideradas nesse processo, a produção oral é a que, muitas vezes, mais motiva o professor, e também o aluno, em todo empenho para a aquisição/aprendizagem efetiva de uma nova língua.

\footnotetext{
${ }^{76}$ No original: "Las destrezas no suelen aparecer de forma aislada en las actividades, sino que casi siempre responden a ese principio de integración en una misma actividad. En la mayoría de los casos aparecen de forma simultánea (...). No necesariamente a una destreza de comprensión auditiva sigue una de expresión oral, o a una actividad de comprensión lectora sigue una de expresión escrita, sino que existe una amplia gama de posibles combinaciones entre las cuatro destrezas, sin que tampoco sea posible establecer un orden definido, ya que cada destreza puede ser propulsora o consecuencia de cualquiera de las otras tres".
} 
O cinema permite aproximar o aluno das principais características da comunicação oral em que, conforme apresenta Pinilla Gómez (2005),

predominam os traços de imediatidade e espontaneidade. Por outro lado, no discurso oral dá-se um conjunto de elementos linguísticos, paralinguísticos e extralinguísticos que facilitam e agilizam a transmissão de mensagens quando os interlocutores partilham ou acreditam partilhar uma versão semelhante do contexto ${ }^{77}$ (p. 887).

No caso do processo de ensino-aprendizagem de uma língua-estrangeira, o cinema como artefato semiótico socialmente construído, pode apresentar muitos outros falantes, de forma a mediar a construção da interlíngua do aluno, tanto em contextos formais como informais de ensino.

\subsection{Considerações}

Os possíveis diálogos entre a arte cinematográfica e a educação foi o fio condutor no trajeto que traçamos neste capítulo. Destacamos a capacidade da sétima arte para representar a vida em seus múltiplos aspectos, enfatizando o potencial representacional das inquietações e desejos mais íntimos da alma humana. Tecemos considerações acerca das várias vias de estudo com vistas à compreensão do cinema, com foco na indústria, nas artes, nas invenções, no entretenimento e ressaltamos seu potencial na formação de novas gerações.

A partir de visões múltiplas e ao mesmo tempo complementares, isto é, tomando o texto fílmico como arte, entretenimento, ferramenta e prática social, traçamos reflexões acerca da sociedade contemporânea submersa em imagens, sons e movimentos, discorremos sobre os vários usos do cinema e vídeo na escola, apresentamos a pesquisa em educação com base nas artes, bem como as contribuições da prática cineclubista para a formação humana e a importância da sétima arte no exercício da competência intertextual.

Conforme apresentamos, o cinema pode contribuir, pelo menos, de três formas com a educação: 1) como recurso didático aliado ao processo de ensino-aprendizagem; 2) como corpus de pesquisa para a compreensão de como a cultura escolar é representada pelo cinema, isto é, como as funções, objetivos, práticas e agentes escolares são veiculadas por essa mídia; 3) como dispositivo desencadeador de reflexões compartilhadas.

\footnotetext{
${ }^{77}$ No original: "predominan los rasgos de inmediatez y espontaneidad. Por otra parte, en el discurso oral se da una conjunción de elementos lingüísticos, paralingüísticos y extralingüísticos que facilitan y agilizan la transmisión de mensajes cuando los interlocutores comparten o creen compartir una versión parecida del contexto".
} 
No caso do ensino-aprendizagem de línguas estrangeiras e da formação de professores de línguas, que é o foco desta tese, o cinema nos brinda com inúmeras possibilidades. Esta mídia pode ter vários proveitosos usos, como ressaltou Moran (1995): vídeo como produção, sensibilização, simulação, pode ilustrar espaços, tempos, culturas e, dentre outras coisas, apresentar mostras verossímeis da língua sem manipulações com fins didáticos, bem como apresentar representações da escola e do trabalho docente. Um exemplo são as aulas produzidas nos estágios supervisionados; que podem ser gravadas gerando material que pode ser analisado em sessões de visionamento, enfim, são inúmeras as contribuições do cinema para potencializar a formação de professores.

Ao longo de cada item relatamos, sempre que possível, pesquisas e trabalhos que expandem as questões aqui apresentadas de forma a ilustrar a riqueza da sétima arte, que em sua composição incorpora várias das outras manifestações artísticas experimentadas pelo ser humano e nos coloca diante do desafio de promover, via ensino, pesquisa e extensão a arte de ver objetivando leituras plurais do mundo.

O próximo capítulo coteja algumas das principais teorias/modelos de aquisição/aprendizagem de língua estrangeira em representações cinematográficas, visando contribuir para a ampliação da compreensão do complexo processo de ensino-aprendizagem de línguas com o qual estamos envolvidos. 
CAPÍTULO 5

\section{ALGUMAS REPRESENTAÇÕES CINEMATOGRÁFICAS DO PROCESSO DE AQUISIÇÃO/APRENDIZAGEM DE LÍNGUAS ESTRANGEIRAS}


$\mathrm{O}$ que se sabe quando se sabe uma língua? Como se adquire esse conhecimento? (GONZÁLEZ, 2004, p. 71).

Hemos estado progresando en espiral desde hace siglos, a base de retomar los mismos problemas bajo nuevas perspectivas (VEZ JEREMÍAS).

O outro guarda um segredo: o segredo do que eu sou (Sartre)

Nunca acreditei em verdades únicas. Nem nas minhas, nem nas dos outros. Acredito que todas as escolas, todas as teorias podem ser úteis em algum lugar, num determinado momento. Mas descobri que é impossível viver sem uma apaixonada e absoluta identificação com um ponto de vista. No entanto, à medida que o tempo passa, e nós mudamos, e o mundo se modifica, os alvos variam e o ponto de vista se desloca (BROOK, 1995, p.15). 
Como aluno, professor e pesquisador, há algum tempo nos dedicamos a aprender e ensinar línguas. Neste capítulo, buscaremos compreender o processo de aquisição/aprendizagem de línguas estrangeiras, ilustrando-o com algumas de suas representações cinematográficas.

Para tanto, iniciaremos nosso trajeto compartilhando a visão de diversos pesquisadores, segundo os quais, ao estudarmos a aquisição/aprendizagem de uma segunda língua/língua estrangeira, nos deparamos com um processo complexo que envolve um número significativo de variáveis.

As principais teorias e modelos de aquisição/aprendizagem de línguas vão da perspectiva linguística à sociocultural. Dentre eles, destacam-se: teoria behaviorista; modelo monitor de Krashen; o modelo da aculturação proposto por Schumann; a Gramática Universal defendida por Chomsky; o conexionismo; a questão da interação; a hipótese do output ou da lingualização reconhecido por Swain e as dimensões socioculturais na aprendizagem de uma língua estrangeira.

Tais estudos foram detalhados por inúmeros pesquisadores. Nesta tese, serão considerados Allwright \& Bailey (1991), Block (2003), Hall (2011), Kumaravadivelu (2012), Larsen-Freeman \& Cameron (2008), Larsen-Freeman \& Long (1994), Mitchell \& Myles (1998), Ortega (2009) e Paiva $(2005,2009,2012,2013)$,autores que foram estudados em sala de aula de maneira detalhada nos dois componentes curriculares e no curso de extensão oferecidos aos participantes da pesquisa ao longo do semestre 2013.2.

A temática já foi explorada em diversos estudos teóricos, dentre eles os que acabamos de citar e, diante do nosso objetivo de averiguar, em um contexto empírico de formação de professores, quais as crenças que os participantes têm acerca do processo de aquisição/aprendizagem da língua e como eles percebem a questão a partir da reflexão mediada pelo cinema, neste momento, é impossível analisar com profundidade cada uma das muitas teorias que já foram propostas a respeito do tema, o que além de resultar em um texto extremamente longo, fugiria ao objetivo desta tese.

Diante do exposto, não pretendemos esgotar o tema, haja vista que estamos diante de uma questão complexa e, embora haja uma imensa quantidade de teorias e modelos, ainda não se chegou a um consenso sobre como se adquire/aprende uma língua, já que nada do que foi proposto até então dá conta de todas as variáveis implicadas no processo. 
Dessa forma, apenas teceremos uma contextualização breve para o leitor nos momentos em que determinada teoria ou modelo de aquisição/aprendizagem for fundamental para ilustrar nossas análises a respeito de algumas representações cinematográficas do complexo processo de ensino-aprendizagem de língua sob as quais nos debruçamos neste capítulo.

\subsection{Em busca da compreensão do complexo processo de aquisição/aprendizagem de línguas estrangeiras}

Explicar o processo de aquisição/aprendizagem de uma língua estrangeira não é tarefa fácil, sendo até considerada um desafio por alguns estudiosos. Paiva (2005) argumenta que a maior dificuldade se encontra no fato de que nenhum pesquisador tem acesso direto às experiências dos aprendizes.

Revuz (1998) alerta para o fato de que é preciso reconhecer que a aprendizagem de línguas estrangeiras se destaca, primeiramente, pela sua alta taxa de insucesso. Segundo a autora, poucas pessoas alcançam o conhecimento suficiente de uma ou várias línguas estrangeiras a ponto de conseguir ler um livro, assistir um filme, conversar com falantes nativos e expressar-se de forma precisa, sem muitas dificuldades.

Para a estudiosa, estamos diante de um paradoxo: um "filhote" de homem, frágil física e intelectualmente, aprende a língua materna em tempo recorde. Quando crescido, dotado de saberes e instrumentos intelectuais, muitas vezes apresenta dificuldades para aprender outros idiomas.

$\mathrm{Na}$ tentativa de melhor decifrar este processo, reconhecemos que o método científico disponibiliza diferentes formas de olhar para o objeto em estudo e que o uso de um único ponto de vista não oferece uma representação adequada daquilo que desejamos compreender. Por outro lado, a adoção de diversos olhares nos permite elaborar um "esboço" do processo que buscamos entender. Apesar da falta de precisão, tal "rascunho" auxiliará na assimilação do tema em análise e nos convidará a continuar este estudo, seja pela concordância ou pelo contraponto necessário à construção do conhecimento. 
Também temos consciência de que "aquisição/aprendizagem" e "língua estrangeira" são conceitos complexos e polissêmicos, mas o conhecimento deve buscar dar conta da complexidade, pois, conforme Machado (2007):

somente o ser humano tem a capacidade de pensar e, consequentemente, sistematizar, ordenar, classificar, analisar, prever os fenômenos do mundo em suas múltiplas dimensões, ou seja, somente o homem é capaz de produzir ciência, somente ele é capaz de realizar trabalho científico, de pesquisar ( $\mathrm{p}$. $1-2)$.

Almeida Filho (2005) ressalta que o processo que buscamos analisar nunca poderá ser captado em sua totalidade. Para ele, na absorção deste processo, estamos reificando o fugidio complexo que não se deixa flagrar sem morrer um pouco. Cientes então de que sempre trataremos de recortes de uma realidade maior, sabemos que este fragmento pode ser estudado por diversos caminhos, nem melhores nem piores, apenas diferentes e, ao mesmo tempo, complementares.

González (2004) apresenta e tece considerações relativas aos diversos lugares de interpretação do fenômeno da aprendizagem de línguas estrangeiras. A pesquisadora usa as palavras de Signorini (1998) para nos alertar sobre o caráter provisório, mutante e processual ao se falar das teorias (da linguagem, da aprendizagem) e do seu instrumental de análise/abordagem/enfoque, que precisa se mover para dar respostas às questões básicas, essas talvez menos mutantes, uma vez que avançamos em espiral há séculos, sempre retomando os mesmos problemas a partir de novas perspectivas.

Em nossa contemporaneidade, os estudos alusivos a como se adquire/aprende línguas se multiplicam em lentes que tentam, sob diversos ângulos, captar respostas para perguntas como: “O que se sabe quando se sabe uma língua? Como se adquire esse conhecimento?" (GONZÁLEZ, 2004, p. 71).

Com relação a isso, Eres Fernández (2003, p. 101-118), argumenta:

É possível responder com relativa facilidade às perguntas fundamentais relacionadas ao processo de ensino/aprendizagem, quais sejam, Quem aprende? e Onde aprende? Porém, não é tão simples encontrar respostas para a questão Como aprende? Pois, dependendo da linha teórica à qual nos filiemos, da nossa concepção de língua e de ensino de língua, das nossas crenças e preconceitos, teremos uma resposta diferente (p. 101-118).

Os possíveis lugares de interpretação da aquisição/aprendizagem de línguas são os mais diversos e apoiados nos aportes teóricos mais variados possíveis. Dessa forma, por 
exemplo, surgem teorias nativistas em oposição a uma visão interacional. E estas vistas parciais se multiplicam, formando um vasto campo onde

encontramos explicações de naturezas as mais variadas para o fenômeno em observação, que vão buscar respostas na questão mais propriamente lingüística, na psicolingüística, na sociolingüística, mais recentemente na análise do discurso e na psicanálise e até mesmo numa teoria que tem suas origens na física, como a da complexidade, atualmente mais entendida como o paradigma da complexidade, pelo qual vêm se explicando vários fenômenos no âmbito das ciências humanas (GONZÁLEZ, 2004, p.72).

Concordamos com Paiva (2005) e diversos autores que apresentam a ideia de que os modelos propostos não contemplam todos os processos envolvidos na aquisição/aprendizagem de uma língua, muito menos os de uma língua estrangeira. Vemos esses modelos como visões fragmentadas de partes de um mesmo sistema. Para a autora, “embora seja possível teorizar acerca da existência de alguns padrões gerais de aquisição, cada pessoa tem as características individuais, sendo impossível descrever todas as possibilidades desse fenômeno" (PAIVA, 2005, p. 23).

Hall (2011), Kumaravadivelu (2012) e Paiva (2005), dentre outros pesquisadores, argumentam que há que se considerar as variações biológicas, de inteligência, aptidão, atitude, idade, estilos cognitivos, motivação, personalidade e fatores afetivos, além das variações do contexto onde ocorrem os processos de aprendizagem - input (qualidade e quantidade), distância e afinidades socioculturais, estereótipos, entre outras.

Neste capítulo, nosso trajeto se iniciou com uma introdução teórica pertinente à complexidade e às dificuldades de compreender o processo de ensino-aprendizagem de uma língua estrangeira. A teoria referente ao complexo processo de aquisição/aprendizagem de línguas nos mostra que não existe uma única e inalterável resposta para a pergunta "Como se aprende uma língua?” e, concomitantemente, não nos aponta um caminho para este fim. A teoria e a prática, contudo, junto com as experiências em sala de aula, nos mostram cada vez mais que este é um processo totalmente particular e subjetivo.

Conforme expusemos anteriormente, não pretendemos esgotar a temática, apenas apresentar os aspectos mais relevantes das teorias de aprendizagem que nos permitam embasar nossas análises e discussões. 


\subsection{Algumas representações cinematográficas do processo de aquisição/aprendizagem de línguas estrangeiras}

Em texto dedicado à reflexão a respeito das crenças referentes ao ensino e à aprendizagem de línguas, Barcelos (2012) afirma que, apesar dos estudos nesta área crescerem significativamente no Brasil, poucos são aqueles que focalizam atividades de sala de aula nas quais tais crenças possam ser discutidas de forma a vislumbrar aos aprendizes possibilidades de elucidar os inúmeros aspectos que envolvem o processo de ensinoaprendizagem de línguas.

Para a autora, "através da discussão de suas próprias crenças e suas histórias de aprendizagem, os alunos podem exercitar a reflexão sobre o que já vivenciaram, o que vivenciam no momento e o que gostariam de vivenciar no futuro" (BARCELOS, 2012, p. 11).

A pesquisadora termina o artigo sugerindo que mais pesquisadores se engajem na elaboração e preparação de atividades que oportunizem aos alunos a reflexão a respeito de crenças sobre ensino e aprendizagem de línguas, em todos os níveis de ensino, mas principalmente nos cursos de formação de professores.

Neste sentido, as atividades que desenvolvemos ao longo do semestre letivo 2013.2, bem como este capítulo, buscam, de certa forma, preencher esta lacuna ao incorporar a discussão a respeito das crenças que permeiam a aquisição/aprendizagem da língua dentro e fora da sala de aula, dando oportunidade aos participantes, via representações da sétima arte, para refletirem a respeito de suas próprias crenças e sobre os obstáculos que possam impossibilitar a ação de acordo com suas crenças e o aprimoramento de seus potenciais para o processo de ensino-aprendizagem.

Podemos afirmar que buscamos promover uma aprendizagem reflexiva nos moldes que Barcelos (2001) apresenta:

A aprendizagem reflexiva, de maneira semelhante ao conceito de ensino reflexivo dos professores, diz respeito à conscientização dos alunos sobre como eles aprendem uma língua estrangeira. Aprender reflexivamente significa abrir a discussão a respeito de crenças, estratégias e estilos de aprendizagem aos alunos, para que eles mesmos possam refletir entre eles e com seus professores sobre sua cultura de aprender, sobre crenças de aprendizagem de línguas e como elas influenciam suas ações para aprender dentro e fora da sala de aula (p. 86).

Dessa forma, neste capítulo aproximamos dois dos nossos temas de interesse: o cinema e o complexo processo de ensino-aprendizagem de línguas estrangeiras. Neste intento, 
lançaremos mão das produções: i) Albergue Espanhol; ii) O Terminal; iii) Espanglês; iv) Um conto chinês; v) O Visitante; vi) Mil anos de orações. A partir de agora apresentaremos, primeiramente, análises individuais dos filmes que compõem nosso corpus e, em seguida, relacionamos as produções entre si.

\subsubsection{Albergue espanhol: em busca do perfil intercultural, o aluno como etnógrafo}

O distanciamento proporcionado pelo envolvimento do aluno no uso de uma língua diferente o ajuda a aumentar sua auto percepção como ser humano e cidadão. Ao entender o outro e sua alteridade, pela aprendizagem de uma língua estrangeira, ele aprende mais sobre si mesmo e sobre um mundo plural, marcado por valores culturais diferentes e maneiras diversas de organização política e social (PCN - LÍNGUA ESTRANGEIRA, 1998, p. 19).

O filme Albergue Espanhol (KLAPISCH, C. [Dir.] L'Auberge espagnole. DVD, Espanha/França: 2003) nos conta a trajetória de jovens de várias nacionalidades (francesa, inglesa, italiana, dinamarquesa, espanhola, alemã e belga) que se juntam em BarcelonaEspanha para estudar. Vemos nos personagens o estranhamento diante do novo, diante de uma língua e cultura diferentes. Estranhar o que é 'diferente' acontece com quem estuda uma nova língua, estando ou não no contexto sociolinguístico da língua estudada, o estranhamento é muito parecido, variando minimamente de acordo com as características individuais.

O processo de aquisição/aprendizagem desse novo conhecimento não acontece de maneira igual para todos os indivíduos, alguns, por diversos fatores, adquirem mais rápido ou lentamente a língua estudada.

A aprendizagem de uma LE é um processo que sofre mediações diversas, ocorre em contextos diversificados e não funciona de forma igual com todos os indivíduos. Como cada ser humano é diferente do outro, os processos semióticos, as conexões efetuadas, serão também diferentes (PAIVA, 2005, p. 29).

Neste momento, resgataremos alguns princípios da competência linguísticocomunicativa, sem pretensões de esgotarmos o tema, e apresentaremos a visão que compartilhamos de competência intercultural.

No que concerne à competência comunicativa, compartilhamos do conceito apresentado por Hymes (1979), sistematizado, posteriormente, por Canale \& Swain (1980) e ampliado por Almeida Filho (1993). Para o antropólogo Del Hymes, esta competência seria a 
capacidade de saber quando falar e quando calar, sobre o que falar, com quem, onde e de que modo. Pensar o ensino de línguas em nossa contemporaneidade implica conceber o aluno como um potencial falante intercultural.

Neste contexto, a partir de Salomão (2012), contaremos com Busnardo (2010) para compartilharmos de uma visão múltipla de cultura já que, no contexto pós-moderno, existem múltiplas culturas em cada estado nação, todas elas em movimento constante.

Dessa forma, “o estático é substituído pelo dinâmico; a 'camisa de força' pelo 'verbo'. São colocadas em questão, sobretudo, noções de 'cultura nacional' e o 'essencialismo cultural', passando-se a pensar em identidades múltiplas - de etnia, gênero, religião, grupo profissional" (SALOMÃO, 2012, p. 108).

Diante do exposto, a cultura é vista um processo constitutivo, um grande mosaico em constante coconstrução e reconfiguração na interação, em oposição a uma noção estática de cultural, como única e homogênea.

Assim sendo, a competência intercultural é compreendida como "a capacidade de perceber, usando-se de todos os mecanismos disponíveis, a diversidade do outro, e sendo capaz de dominar seus sentimentos pessoais, de neutralizar suas crenças e de pensar de forma a poder se colocar no lugar do outro" (SALOMÃO, 2012, p. 108).

Byram (1997) apresenta o modelo de competência comunicativa intercultural sendo composto pela competência linguística, competência sociolinguística, competência discursiva e competência intercultural. Para o pesquisador, a competência intercultural abarcaria savoir comprende (interpretar), savoir faire (descoberta/habilidades de interação), savoir (conhecimento - de si próprio e dos outros), savoir s'engager (consciência cultural crítica) e savoir être (atitudes).

$\mathrm{O}$ autor explica que o fator atitude refere-se à habilidade de relativizar a si próprio e a valorizar o outro (savoir être). Já o conhecimento de si próprio e do outro significa conhecimento de regras para a interação individual e social e consiste em conhecer grupos sociais e suas práticas, tanto na própria cultura como na cultura do outro (savoir). Dessa forma, interpretar descreve a habilidade de o indivíduo interpretar, explicar e relacionar eventos e documentos da cultura do outro com a própria cultura (savoir comprende). Descoberta e interação permitem ao indivíduo adquirir novos conhecimentos de cultural e práticas culturais, incluindo a habilidade de usar conhecimentos, atitudes e habilidades existentes em interações interculturais (savoir faire). Por fim, a consciência cultural crítica 
descreve a habilidade de fazer uso de perspectivas, práticas e produtos na própria cultura e na cultua do outro para realizar avaliações (savoir s'engager).

O aprendiz que consegue alcançar a competência linguístico-comunicativa tem potencial para conquistar um perfil intercultural, pois além de se comunicar adequadamente em contextos interculturais, terá sensibilidade para perceber o impacto que a diferença cultural exerce no processo comunicativo.

Barro, Jordan \& Roberts (2001) propõe a ideia de interculturalidade a partir da releitura do conceito de competência comunicativa de Del Hymes, bem como de sua visão de etnógrafo, pois para ele desde os nossos primeiros dias de vida buscamos entender o mundo que nos rodeia observando, escutando e, com o tempo, falando. Os autores fazem referência ao conceito do antropólogo como "competência que forma parte das práticas sociais e culturais de uma comunidade, na qual a língua ocupa posição central ${ }^{78, "}$ (BARRO, JORDAN \& ROBERTS, 2001, p. 82).

Esta releitura propõe a etnografia como forma de estudar o outro e, assim sendo, as estruturas sociais e culturais que dão sentido à sua vida. Sabemos que, infelizmente, o componente sociocultural é sempre posto em relevo na teoria, mas em práticas de ensino, na maioria das vezes, sempre fica em segundo plano, cabendo ao professor o papel de mediador cultural:

O perfil profissional que [...] chamarei de professor de língua como interculturalista corresponde a um docente [...] apto para realizar práticas de mediação sócio-cultural, contemplando o tratamento de conflitos identitários e contradições sociais, na linguagem (SERRANI, 2005, p.15).

Albergue Espanhol e os demais filmes que compõem nosso corpus nos proporcionam reflexões importantes para essa prática intercultural que, quando levada a cabo, só trará benefícios para o aprendiz, vinculando conhecimento e sensibilização cultural em prol de seu próprio aperfeiçoamento linguístico.

Nosso cuidado ao difundirmos uma língua estrangeira e, consequentemente, sua cultura, é fazê-lo com responsabilidade. No filme, as nacionalidades se mesclam e se chocam, mas se respeitam. O conceito de interculturalidade, de forma geral, diz respeito a uma consciência crítica e de convivência respeitosa do indivíduo com a cultura do outro, e é essa visão que determinará sua postura diante do diferente. O falante intercultural, portanto, é

\footnotetext{
${ }^{78}$ No original: "competencia que forme parte de las prácticas sociales y culturales de una comunidad, en la cual la lengua ocupa un lugar central".
} 
aquele que compreende a multiplicidade cultural, e a iguala no patamar de diferentes e complementares (AGUILERA REIJA et al., 1996).

A personagem principal Xavier -que é francês- está exposta ao contexto linguístico da língua que quer aprender, e é nas ruas, mais precisamente nos bares da cidade, que ele aprende a língua espanhola, pois é fora dos padrões linguísticos, dos meios tidos como formais, que a língua é propagada como realmente ela é. É no meio social que a personagem desenvolve estratégias e cria hipóteses para lidar com a língua, inteirando-se com o meio e com o outro. Os aprendizes de uma segunda língua, assim como as personagens do filme, têm que estar dispostos a receber e a buscar novas informações, para que possam compreender e respeitar o outro, saber que fazem parte de mundos característicos, e que não existe uma cultura melhor que a outra, e sim, apenas diferentes.

Embora o objeto principal com que o estudante vai se relacionar seja a língua, participam nessa relação a forma como vê outros elementos a ela unidos, tais como: os falantes dessa língua e as culturas que expressa. Assim, ao se localizar no espaço do estereótipo ou do preconceito com relação a qualquer um destes objetos o aprendiz terá refletidas estas imagens no seu aprendizado (SANTOS, 2002, p. 03).

As descobertas que surgem nesse processo de conhecer a língua e a cultura do outro são essenciais para construção do conhecimento, pois é percebendo o outro e suas intenções ao falar que criamos noções de significados. Quando falamos em língua estrangeira, sabemos que estamos diante de uma construção ideológica diferente da nossa língua materna, onde temos culturas diferentes. E é essa característica particular que nos difere das demais línguas e culturas. Onde não há interação, não há comunicação, os indivíduos necessitam interrelacionar-se para que haja discurso.

\subsubsection{Um mundo em ebulição e a disposição ao novo}

Não sei porque o mundo se tornou essa complicação. Não sei se o mundo deveria ter ficado assim. Tudo é complicado, difícil, confuso. No passado, havia campos com vacas, galinhas. Tudo era simples, creio eu. Havia uma relação direta com as coisas. No mundo de Martine tínhamos animais, comíamos o que plantávamos, fazíamos as roupas, construíamos as casas. Eu me pergunto por que deixamos o mundo de Martine.

$[\ldots]$

Eu era um menino loiro, e queria escrever. Então, mudei. Nós podemos mudar, não é?

(Pensamentos da personagem Xavier no filme Albergue Espanhol) 
Albergue Espanhol, produção do francês Cédric Klapisch ${ }^{79}$, lançada em 2003, apresenta a contemporaneidade múltipla e apressada em que vivemos; nele aparece Xavier, que aos 25 anos deixa a França para morar um ano na Espanha. Em Barcelona, o jovem pretende, além de aprender a língua do país, cursar uma pós-graduação focada na economia espanhola, já que esta formação aliada à vivência com a língua lhe garantirá, ao regressar, uma oportunidade de trabalho, prometida por um amigo do seu pai, conforme apresenta a fala abaixo:

Eu só sei que com as novas diretrizes europeias teremos novos empregos em um ano. Se fizer pós-graduação voltada para a economia espanhola posso te arrumar um emprego. Existem boas possibilidades. Mas precisa falar bem a língua espanhola e conhecer o mercado espanhol. ¿Hablas español? [...] Esteve na Espanha? (Fala da personagem Jean-Charles Perrin)

Disposto a conhecer o novo, nosso protagonista tem algumas dificuldades em conseguir moradia, até que aluga um quarto num apartamento onde residem outros cinco estudantes, todos de países diferentes: Alessandro é italiano, Tobias, alemão, Lars, dinamarquês, Wendy, inglesa e Soledad, espanhola.

Adorei aquele lugar de cara. Faria tudo para ser aceito. A confusão do grupo era a mesma que existia dentro de mim. Era como se as discussões deles existissem desde a minha infância (Fluxo de consciência da personagem Xavier).

A contemplação deste filme, enquanto arte, gera -como um caleidoscópio- diversas possibilidades de significação. Sem a intenção de esgotarmos todas as leituras possíveis, tematizamos aqui algumas imagens relacionadas ao processo de ensino-aprendizagem de línguas que nosso olhar atento, de cientista da linguagem e admirador da arte cinematográfica, conseguiu captar.

Paiva (2005) argumenta que nunca podemos afirmar, com segurança, o que vai ocorrer num processo de aprendizagem, pois o que funciona para um aprendiz pode não ser significativo para outro. Isto é o que podemos observar no caso de Xavier e Anne-Sophie, os dois personagens são franceses e vivenciaram várias experiências juntos em Barcelona, mas o que serviu como estímulo à aquisição/aprendizagem de Xavier, na maioria das vezes não funcionou com Anne-Sophie. Dito de outra maneira, ele tinha uma atitude de prontidão ao outro e sua cultura e ela não. Como consequência, ele adquiriu competência comunicativa

\footnotetext{
${ }^{79}$ Para mais informações consulte: http://www.cedric-klapisch.com/ (Website oficial deste cineasta) Acesso em: 10 jun. 2013.
} 
intercultural no idioma e ela, apesar de estar imersa no mesmo contexto, não se permitiu conviver com o outro de forma a adquirir/aprender a língua espanhola.

Schumann (1978) apresenta ser o processo de aquisição/aprendizado de uma língua um processo de aculturação, de adaptação ao grupo social falante daquela língua. Neste sentido, Paiva (2005) argumenta que:

$\mathrm{Na}$ aprendizagem também temos uma situação estável que uma força qualquer vem perturbar. Disto resulta um estado de desequilíbrio. Pela ação de uma força dirigida em sentido inverso, o equilíbrio é reestabelecido; o segundo equilíbrio é semelhante ao primeiro, mas os dois nunca são idênticos (p. 28).

Diante do exposto, podemos sugerir que Xavier, diante do novo, isto é, ao se ver sozinho na Espanha, vivenciou diversas situações que o desestabilizaram por não ter conhecimento da língua e que essas situações foram convertidas, por ele, em fontes de motivação para adquirir/aprender mais, já Anne-Sophie deu ênfase ao sentimento de incompreensão e não buscou superar a fase inicial de desconforto diante da necessidade de adaptação ao novo.

Dessa forma, a aquisição/aprendizagem de uma língua não se apresenta como algo estático, mas sim como um processo complexo e dinâmico, que demanda movimento e mutação dos envolvidos. Dito de outra maneira, se nos limitarmos apensas ao input que nos é apresentado, nosso desenvolvimento será inferior ao de quem a partir do input já conhecido busca o novo, ou seja, o input+1 e se engaja na produção de output.

Xavier não se limitou a receber os inputs, ele produzia constantemente outputs ao tentar interagir com os outros, o que está te acordo com a teoria apresentada por Swain (2006), a pesquisadora argumenta que os aprendizes devem se empenhar em produzir output compreensível de forma a mover a interlíngua da análise semântica para a análise sintática do input.

Paiva (2013), ao discutir as ideias de Swain, apresenta que o "output levaria a um maior esforço cognitivo do que demanda o input e coloca o aprendiz no controle de sua aprendizagem (p. 3)". Neste sentido, a pesquisadora argumenta que "ao escrever ou falar, os aprendizes estão agindo com a linguagem e é na ação comunicativa que percebem o que são ou não capazes de fazer com a linguagem" (p. 3).

O output como processo de aquisição/aprendizagem explica a possibilidade aprender com a língua em ação em contextos sociais de uso, já que os aprendizes procuram soluções 
para as dificuldades linguísticas encontradas a partir de atividades sociais nas quais eles estão engajados na coconstrução de significados, num processo que demanda percepção, possibilita testar hipóteses e promove a reflexão metalinguística.

Diante do exposto, quando Xavier se envolve em atividades relevantes de interação nas ruas, na república de estudantes em que vive e na universidade, ele age com e sobre a linguagem e a partir dessas situações reais de construção e negociação compartilhada de sentidos consegue perceber o que é capaz ou não de realizar com a competência linguísticocomunicativa adquirida e projetar novas metas que irão contribuir na sua aprendizagem.

\subsubsection{Línguas em contato podem gerar conflitos: é preciso saber administrá-los}

A gíria L'Auberge espagnole é apresentada por D’Olim Marote (2002, p.42) como casa da sogra. Em outras palavras, lugar onde as culturas se misturam e não há regras, onde tudo pode acontecer. Este contexto colabora com a nossa análise: um cenário de confusões cômicas proporciona aos participantes novas maneiras de ver a si e ao mundo que os cerca.

Tudo gerado pelo caos inicial - uma confusão que acontece em nossa cabeça quando nos permitimos aprender a representar em uma nova língua-. Bem articulados, os jovens desta obra enfrentam com inventividade os desafios impostos pela cultura espanhola e pela própria diversidade de sua república: como podemos observar no caso do atendimento telefônico, ao lado do aparelho está fixada uma tabela que informa a maneira correta de atender as ligações telefônicas dos parentes dos estudantes em cada uma de suas línguas maternas.

Quando nos dispomos a conhecer o novo, faz-se necessário enxergar o outro, conhecendo-o e respeitando sua maneira singular de ser, além disso, é recomendável tomar cuidado com os estereótipos: um ótimo exemplo disso é a inclusão, no filme, de um jovem inglês que insiste em fazer generalizações sobre cada país, repetindo frases como: "Vocês, franceses, são sempre...", "Os espanhóis adoram...", causando constrangimentos, como ao adotar Hitler como "modelo" do comportamento dos alemães.

\subsubsection{A Espanha que não fala espanhol}

Levando-se em consideração que cada língua representa uma visão particular de mundo, preservando a identidade dos que a falam, temos que concordar que poucas vezes o 
professor de E-LE apresenta aos alunos a realidade de uma Espanha que não fala espanhol, mostrando que a unidade deste país não se faz só pelo Castelhano, mas sim pela convivência entre o Galego, o Catalão, o Vasco.

Ao entendermos a competência sociolinguística como a capacidade do falante de se comunicar adequadamente nos mais variados contextos, faz-se necessário levar estes mundos possíveis para a sala de aula. Ainda que essas línguas não sejam abordadas de forma aprofundada, é preciso que sejam apresentadas aos aprendizes.

\subsubsection{O "bar" como local privilegiado para aquisição/aprendizagem da linguagem coloquial}

Chega o momento em que o nosso protagonista entende o que é aprender uma língua estrangeira em situações reais de comunicação, ele é levado a um bar onde, nas palavras dos personagens se aprende o espanhol de "puta madre", expressão popular que, neste contexto, pode ser compreendida como "o melhor espanhol".

Sobre o espanhol coloquial, Briz (1998) ressalta que é um registro, nível de fala, um uso determinado pela situação, pelas circunstâncias de comunicação e acrescenta que não é domínio de determinada classe social, mas que, caracteriza as realizações de todos os falantes de uma língua. Esta forma de expressão não é uniforme, levando-se em conta que muda conforme as características dialetais e sociais sendo, portanto, importante proporcionar ao aprendiz oportunidades para que ele perceba isso. O professor deve ter em mente que preparar o aluno para situações reais de comunicação exclui uma visão preconceituosa de linguagem coloquial.

\subsubsection{Desafios}

Para o aprendiz, que ao longo de sua jornada - dentro e fora da sala de aula - se depara com muitas variedades de uma mesma língua pode ser, inicialmente, um pouco confuso lidar com todas elas. Às vezes, sentirá o mesmo caos que habitava a cabeça do personagem Xavier, porém é preciso levar em conta que as habilidades para poder saber quando, onde e como significar em determinada variante linguística em detrimento de outra é algo que só se aperfeiçoará na própria prática da língua. 
Este filme deixa àqueles que se aventuram no ensino de línguas estrangeiras no Brasil o desafio de levar esta produção cinematográfica para a sua sala de aula, trabalhar os múltiplos aspectos que contemplamos neste trabalho (além de outros não enfocados pelo nosso olhar) e verificar as percepções que os alunos têm da ideia do aprendiz intercultural, veiculada por esta obra.

\subsubsection{Multiculturalismo e o processo de aquisição/aprendizagem de línguas estrangeiras representado em Um conto chinês}

Em Um conto chinês (BORENSZTEIN, Sebastián [Dir.] Un Cuento Chino. DVD, Argentina: 2011) são representados dois extremos em termos de cultura e de língua para além da dicotomia Ocidente e Oriente: um argentino e um chinês convivendo sob o mesmo teto. $\mathrm{O}$ filme nos mostra os desafios da convivência com uma cultura desconhecida, e como o respeito, a amizade e a comunicação não verbal - características universais do ser humano podem, pouco a pouco, romper barreiras e servir como veículo de interação.

$\mathrm{Na}$ tela de projeção nos vemos diante de Roberto - que é argentino - e Jun - que é chinês - que se encontram acidentalmente. Jun por uma fatalidade decide ir à Argentina em busca de seu tio, seu único parente vivo, e que, logo ao chegar à cidade, é enganado por ladrões e assaltado. Roberto, até então desconhecido, assiste a essa cena e tenta ajudar. Leva Jun para a sua casa (por falta de opção), por estar este desabrigado. Mas Roberto tenta, a todo custo, se ver livre dele. Daí começa o difícil convívio entre as duas personagens, pois, eles não se entendem, falam línguas completamente distintas, e com isso, não conseguem interagir.

Vários são os fatores que influenciam o indivíduo no momento de aprender uma língua estrangeira, e isso, principalmente, depende de se o indivíduo tem o desejo, ou não, de aprender essa nova língua: "nenhum método é capaz de impedir que qualquer um que tenha o desejo de aprender uma língua estrangeira o faça!” (REVUZ, 1998, p. 216).

No filme, o processo de aquisição/aprendizagem de língua estrangeira não acontece, por um fator primordial, a falta de alteridade de Roberto, pois, sua personalidade forte e "fechada" o impossibilita sustentar relações sociais e amorosas com os demais, e o seu desinteresse em manter qualquer tipo de contato pessoal prejudica a tentativa de entender a língua de Jun. 
Para interagir é preciso ir além do estranhamento inicial, não pré-julgar e não discriminar; é preciso dançar conforme a música que o outro toca (GOETTENAUER, 2005). Isso acontece porque o indivíduo que deseja adquirir um novo conhecimento tem que estar aberto para recebê-lo, tem que nutrir esse desejo de aprender essa nova língua, com esforço, envolvimento e interação.

\subsubsection{Não falam a mesma língua... e agora?}

Bakhtin (2007) nos apresenta que todo homem passa por dois nascimentos: um físico e outro social. Para o filósofo “o indivíduo humano só se torna historicamente real e culturalmente produtivo como parte do todo social (p. 11)". O pensador russo argumenta que nascer fisicamente não é o suficiente para fazer parte da história.

Segundo o filósofo, é necessário algo como um segundo nascimento, um nascimento social:

O homem não nasce como organismo biológico abstrato, mas como fazendeiro ou camponês, burguês ou proletário: isto é o primordial. Ele nasce como russo ou francês e, por último, nasce em 1800 ou 1900. Só essa localização social e histórica do homem o torna real e lhe determina $\mathrm{o}$ conteúdo de criação da vida e da cultura (BAKHTIN, 2007, p. 11).

Neste sentido, o filme objeto de nossa análise é baseado em fatos reais e nos apresenta Jun e Roberto, duas personagens com nascimento social bastante distinto: o primeiro nasceu na China e fala cantonês; o segundo é argentino, filho de imigrante italiano e fala espanhol rio-platense.

De imediato, essas condições de nascimento social tão distintas não seriam um problema, porém, a vida dos dois - por coincidência - se cruza: num belo dia, enquanto Roberto segue à risca a sua rotina, presencia Jun sendo assaltado e jogado para fora de um taxi e, desta forma, o chinês se vê perdido na Argentina em busca do tio.

Desde o primeiro encontro a relação entre os dois é conflituosa: um não fala a língua do outro e, como consequência, eles não se entendem. De imediato, haver tido o nascimento físico semelhante e passado por algumas situações semelhantes na vida não é suficiente para que haja intercompreensão.

Logo nas primeiras cenas do filme, Roberto lê a carta que recebeu há seis meses de Mari, que não obteve resposta já que ele fingiu não haver recebido: 
Querido Roberto: durante as 3 horas no ônibus até o povoado não parei um instante de pensar em você. É certo que eu mal te conheço, mas assim que te vi na casa da minha irmã senti que te conhecia a vida inteira. Talvez por que há duas coisas que percebo logo nas pessoas: a nobreza e o sofrimento. $\mathrm{E}$ você tem ambos (BORENSZTEIN, 2011).

O conteúdo revelado ao expectador nos antecipa o que perceberemos mais tarde, ao longo do filme: estaremos diante de duas personagens de localidades e línguas tão distantes, mas com algo em comum, a nobreza e a dor: Roberto não conheceu a mãe, já que ela faleceu durante seu parto e Jun perdeu a noiva, em um trágico acidente em Fucheng - China -, quando uma vaca, misteriosamente, caiu do céu.

Várias vezes, Roberto tenta abandonar Jun à própria sorte, tendo como base a convicção de que o chinês não é problema dele. Em todas as tentativas, a consciência humana lhe alcança e ele termina se envolvendo cada vez mais com o caso.

A convivência entre os dois é tensa e forçada, muitas vezes o não verbal passa a ser estratégico para amparar a necessidade humana de interação social, o contato entre línguas e, consequentemente, suas culturas. Em outras ocasiões falta a alteridade e, diante da recusa de Roberto da convivência com o outro, ainda que Jun lance mão de vários recursos extraverbais, a interlocução não ocorre.

Inicialmente, o estranhamento seria até compreensível, já que como foi consagrado "Narciso acha feio o que não é espelho" e a adaptação ao que é diferente de si próprio leva um tempo que pode variar de pessoa para pessoa. Porém, passado o choque inicial, é necessário o cultivo da alteridade, na busca por compreender e conviver com o outro.

Revuz (2002) destaca que "toda tentativa para aprender outra língua vem perturbar, questionar, modificar aquilo que está inscrito em nós com as palavras dessa primeira língua (p. 217)”. A pesquisadora argumenta que muito antes de ser objeto de conhecimento, a língua é o material fundador de nosso psiquismo e de nossa vida relacional.

Conforme destacamos no item "variação e preconceito" do capítulo 3, diante do contato do indivíduo com outras culturas pode ocorrer o etnocentrismo, o relativismo cultural ou o interculturalismo. Ao longo do filme podemos observar que o trajeto traçado por Roberto do etnocentrismo ao interculturalismo é longo e cheio de descobertas:

A experiência da alteridade (e a elaboração dessa experiência) leva-nos a ver aquilo que nem teríamos conseguido imaginar, dada a nossa dificuldade em fixar nossa atenção no que nos é habitual, familiar, cotidiano, e que consideramos 'evidente'. Aos poucos, notamos que o menor dos nossos comportamentos (gestos, mímicas, posturas, reações afetivas) não tem 
realmente nada de 'natural'. Começamos, então, a nos surpreender com aquilo que diz respeito a nós mesmos, a nos espiar. $\mathrm{O}$ conhecimento (antropológico) da nossa cultura passa inevitavelmente pelo conhecimento das outras culturas; e devemos especialmente reconhecer que somos uma cultura possível entre tantas outras, mas não a única (LAPLANTINE, 2000, p.21).

Dessa forma, ao longo da narrativa fílmica podemos observar uma mudança considerável na postura de Roberto em relação a si mesmo e aos outros, na perspectiva da convivência com a diversidade e a alteridade.

Roberto vivia fechado em seu mundo e acreditava ser injusto quando alguém faltava com a honestidade para com ele. Exemplo disso é que ele contava conferindo a quantidade de parafusos que vinham do fornecedor, mostrando desconfiança em relação à honestidade ou ao precário controle de qualidade do fabricante. Porém, em contrapartida, irrita-se quando o cliente pede para que ele pese os parafusos solicitados, mostrando desconfiança, ficando claro que centra no seu eu a referência da alteridade, como uma relação de mão única.

A noção de alteridade de Roberto, por vezes oscilante ao longo da narrativa, acaba passando por uma ressignificação quando, no final do filme, percebe que a convivência com Jun the mostrou que o receio da cumplicidade e o desvelar de seus medos e intimidades com relação a Mari não seriam obstáculos, mas elementos constituintes de uma possível relação amorosa.

\subsubsection{A subcompetência estratégica para compensar desarranjos na comunicação}

É consenso entre os estudiosos do complexo processo de ensino-aprendizagem de línguas que a expressão oral é uma das atividades comunicativas que se pode desenvolver durante um ato comunicativo e nela "processamos, transmitimos, intercambiamos e negociamos informação com um ou vários interlocutores ${ }^{80 " ~(P I N I L L A ~ G O ́ M E Z, ~ 2005, ~ p . ~}$ 879).

A autora apresenta que o contexto de uma situação comunicativa está integrado pelas circunstâncias espaço-temporais e por outros fatores, como o entorno sociocultural e as relações que se estabelecem entre os participantes. Para ela, influenciam no processo

${ }^{80}$ No original: "procesamos, transmitimos, intercambiamos y negociamos información con uno o varios interlocutores". 
comunicativo questões como idade, gênero, grau de intimidade e interpretação das intenções, entre outros (PINILLA GÓMEZ, 2005).

Diante de uma situação comunicativa determinada, é sabido que o valor comunicativo de uma mensagem vai ser influenciado pelos elementos linguísticos e extralinguísticos, como palavras, interesses, desejos, objetivos, atitudes, trajetórias, valores e conhecimentos das pessoas envolvidas.

Uma das caracterizações mais conhecidas e completas dos elementos que integram e condicionam uma situação comunicativa foi desenvolvido pelo etnógrafo da comunicação Dell Hymes $\left(1974^{81}\right)$ e corresponde ao acrônimo da palavra inglesa SPEAKING:

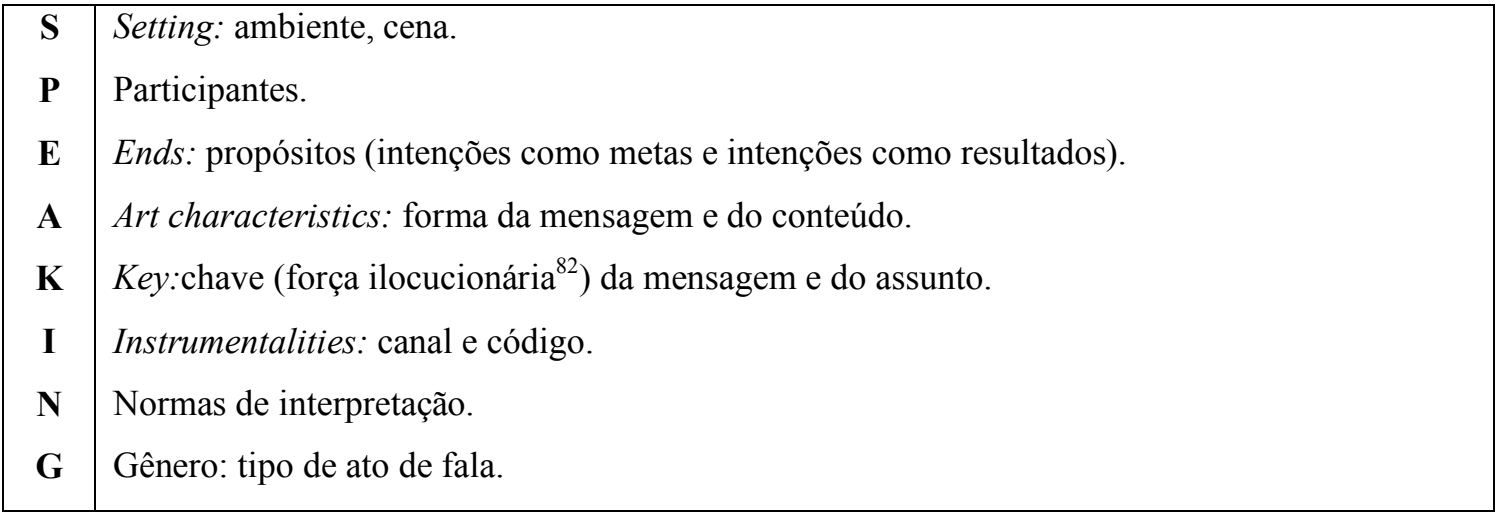

Quadro 12: Elementos de uma situação comunicativa. Fonte: Pinilla Gómez (2005, p. 881) - tradução nossa.

O desempenho do falante dentro de determinada situação comunicativa vai depender, dentre outros elementos, da sua subcompetência estratégica, que é a capacidade que engloba estratégias de comunicação verbal e não verbal que podem ser usadas para compensar desarranjos na comunicação em função das variáveis de desempenho e competência insatisfatória, isto é, estratégias das quais o falante poderia lançar mão tanto para aumentar a eficácia da comunicação ou compensar possíveis problemas.

No caso do nosso filme em análise, existe uma situação comunicativa em que, na cozinha, quando Jun Hio queria fazer uma refeição com ovos, ele lançou mão da mímica como estratégia de comunicação para compensar as falhas causadas no processo comunicativo pelo fato deles não dominarem o mesmo código linguístico, mas Roberto, seu interlocutor, se negou a entender e o ignorou.

\footnotetext{
${ }^{81}$ Apud Pinilla Gómez, 2005, p. 881.

${ }^{82}$ Ilocução: a intenção que tem o falante ao emitir as palavras (sentido pretendido).
} 

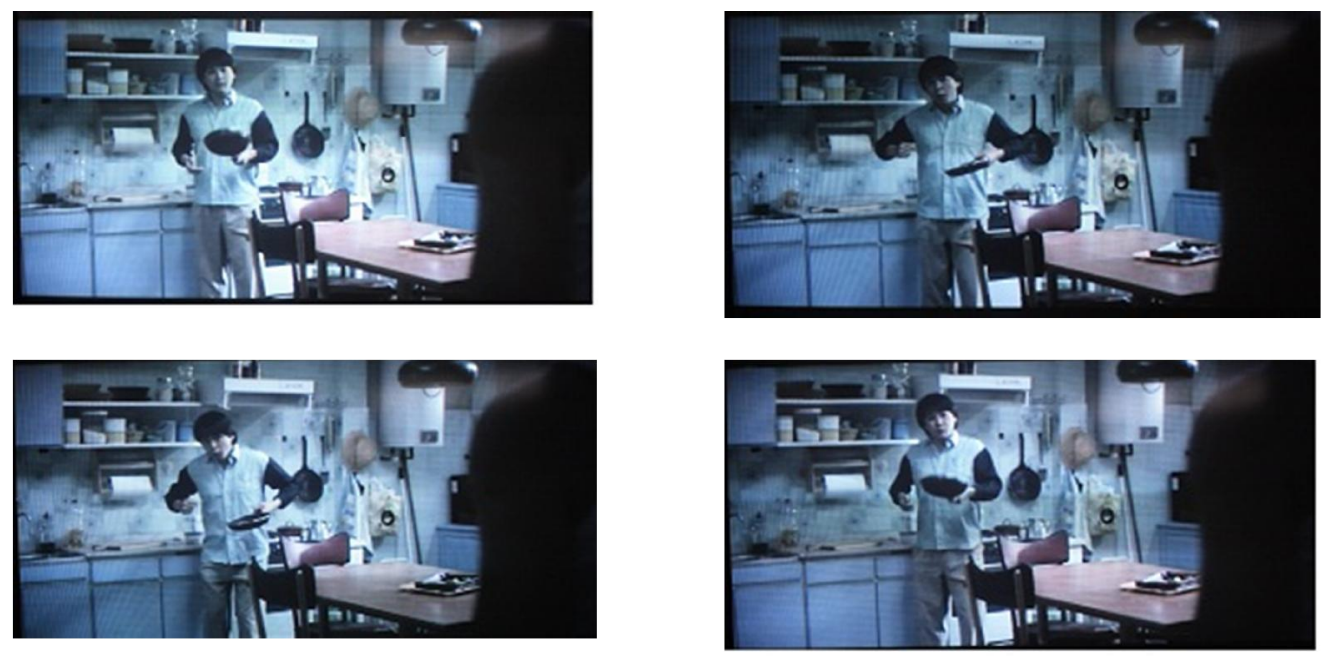

Imagem 7: cenas do filme Um conto chinês.

Podemos observar, nesta situação comunicativa apresentada pelo filme, que Jun utilizou com muita destreza a subcompetência estratégica para compensar suas deficiências comunicativas e as possíveis falhas no processo comunicativo: ele imitou uma galinha batendo as asas e emitindo ruídos para botar um ovo. Porém, sua intencionalidade não se concretizou por falta de interesse de Roberto, seu interlocutor, que, mesmo tendo claramente ideia do que ele queria expressar o ignorou e o deixou falando, ou melhor, gesticulando sozinho.

Pensar na convivência entre línguas e, consequentemente, na aquisição/aprendizagem de outras línguas implica conceber quem se arrisca a esta aventura como um potencial falante intercultural. Para Giménez (2001, p. 113), o falante interculturalmente competente seria aquele que opera sua competência linguística e sua conscientização sociolinguística a respeito da relação entre língua e o contexto em que é usada, a fim de interagir ao longo de fronteiras culturais, prever mal-entendidos, decorrentes de diferenças em valores, significados e crenças, e, finalmente, para lidar com as demandas cognitivas e afetivas do engajamento com o outro.

\subsubsection{Comunicar-se é uma capacidade inerente ao ser humano...}

Ainda que a interação e, por conseguinte, a comunicação sejam características próprias do ser humano, podemos notar que no ambiente em que vivem (e não necessariamente convivem) Roberto e Jun quase não há comunicação. Em diversas situações do filme ocorre comunicação não verbal, porém, na maioria das vezes a força ilocucionária não se concretiza. 
Em outras palavras, como expusemos no item anterior, a intenção que tem o falante ao se expressar acaba não sendo atendida, dando-nos a ideia de não-comunicação.

Falta ao Roberto a alteridade para poder olhar para o outro. A comunicação quase não ocorre porque não há interesse por parte dele, como podemos notar em vários trechos do filme. Destacamos como exemplo a noite em que Roberto e Jun são convidados para jantar na casa dos parentes de Mari. As pessoas reunidas, ao se dar conta de que Jun não entendia o que eles diziam, reproduziram vários estereótipos negativos em relação aos chineses e Roberto, com uma postura de pouco caso, reforçou o comportamento negativo dos presentes:

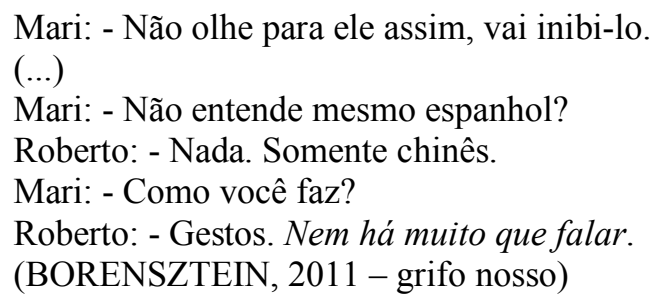

Outro exemplo claro do desinteresse de Roberto pelo seu interlocutor pode ser notado quando ele recebe um contato telefônico de um suposto tio de Jun e que, mesmo sendo já tarde, ele insiste: "Não poderiam vir ainda hoje [para buscá-lo]? A hora que for. Sem problema".

Antes de ter um contato mais intenso com Jun, Roberto achava que todo chinês era igual e falava a mesma língua, ou seja, ele homogeneizava a cultura do outro, não observando suas particularidades. Outra situação semelhante é a que apresenta o comportamento simplificador de Roberto quando leva Jun ao bairro dos chineses em Buenos Aires: uma nação, por mais tradicional que seja, apresenta várias especificidades, como, por ex., nem todo chinês fala a mesma língua (cantonês, mandarim). Dessa forma, nosso protagonista tem a crença negativa de cultura como um monobloco correspondente ao Estado-Nação.

Roberto oscilou da falta de alteridade para a extrema alteridade com a mediação, o tempo todo, da Mari, que exerceu um papel fundamental nesse processo. Muitas vezes, na narrativa, quem exercia o papel da alteridade e buscava a interação era Mari, uma conhecida de Roberto. Em um momento em que ela conversa e mostra fotos ao chinês, Roberto questiona: "Por que fala com ele se ele não entende?"; e ela responde: "Entende as fotos"; e continua buscando integrar o "estranho" ao grupo.

Em outra situação, ela leva Jun para passear pela cidade. Para obter o consentimento de Roberto, ela diplomaticamente argumenta: "Sei que você tem que trabalhar e está muito 
ocupado. Mas tive uma ideia. O seu chinês não é daqui e não conhece a cidade. Nem eu. Então, pensei em levá-lo comigo, mostrar as coisas lindas que há por aí e passear um pouco. O que acha?". Ao final do dia, quando retorna para entregar Jun, ela confirma: "Não imaginava me divertir tanto com alguém sem entender uma única palavra. Fomos ao Planetário, alugamos bicicletas (...) (BORENSZTEIN, 2011)”.

Mari exerce o papel de mediador/integrador intercultural. É ela quem, numa noite em que encomendam um jantar especial para comemorar que o suposto tio de Jun foi encontrado e que virá buscar o rapaz, descobre o entregador de comida chinesa que fala a língua do hóspede e feliz anuncia: “Temos tradutor. Mas é rápido, [ele] precisa voltar ao trabalho. Fale com ele. Cumprimente-o. Diga que amanhã as 9 o tio virá buscá-lo caso não tenha entendido". Empolgada com a chance de maior interação diante do tradutor improvisado ela declara: "Tenho tanta curiosidade que faria a ele mil perguntas"; e, ao mesmo tempo é interrompida por Roberto: “Mas não hoje, porque a comida irá esfriar" (BORENSZTEIN, 2011, grifo nosso).

Roberto aborta a tentativa de interação porque não há alteridade. O interesse é de livrar-se o mais rápido possível do hóspede indesejado. Não há desejo de dialogar, ou seja, conhecer, interagir com o outro. Ele era metódico, cheio de manias (gostava de colecionar coisas, contava os parafusos das caixas, se negava a comprar um computador para a sua loja, implicava com seus clientes) e de difícil relacionamento. Enfim, como esperar mais flexibilidade de alguém que não se permite, por exemplo, dormir às $22 \mathrm{~h} 59$, já que impôs para si próprio dormir todos os dias às $23 \mathrm{~h}$ ?

Talvez até mesmo por resquício de sua época de soldado de guerra, Roberto seguia sua rotina à risca e não queria adaptar-se ao novo: nem à Mari, uma mulher bem resolvida, que se empenhava para ter um relacionamento com ele (que durante quase todo o filme é frustrado), muito menos ao Chinês que precisava de ajuda. Ele foge de todas as relações, inclusive de si mesmo.

\subsubsection{Reflexões}

A análise do complexo processo de ensino-aprendizagem de línguas estrangeiras e a representação de alguns dos seus elementos na produção cinematográfica argentina Um conto chinês (2011) foi o fio condutor do trajeto que traçamos neste item. 
O filme objeto de nossa análise leva à tela os conflitos de convivência entre pessoas de culturas diferentes e nos mostra a necessidade da alteridade e de uma postura intercultural para promover a intercomunicação. Ao unir teorias de aquisição/aprendizagem à mensagem veiculada pelo filme, esperamos ter colaborado com aqueles que se dedicam a aprender e ensinar línguas, de forma a alcançarem uma maior compreensão do processo complexo com o qual estão envolvidos.

No filme, com o passar do tempo Jun ia se sentindo mais seguro na casa de Roberto, ou seja, menos ameaçado de ficar sem abrigo. A segurança possibilitou a ele revelar-se como ser humano dotado de uma trajetória e de alguns dons artísticos, como pintor e artesão. A narrativa não nos revela se Jun chegou a aprender espanhol, mas acreditamos que sim. Roberto acreditava que a vida não fazia sentido e era um grande absurdo; já para Jun tudo tem um sentido e sua passagem pela vida de Roberto mudou a sua forma de interagir consigo mesmo e com os outros.

\subsubsection{O terminal como porta aberta à aquisição/aprendizagem de uma nova língua}

O processo de desestrangeirização de uma língua pode ser assistido desde " $O$ Terminal” (SPIELBERG, S. [Dir.] The terminal. DVD, EUA: 2004) e é possível extrair diversos significados das situações pelas quais Viktor Navorski passa. Nossa personagem é um cidadão da Europa Oriental (Krakozhia, um país fictício) que ao chegar a Nova Iorque não consegue visto e, consequentemente, não pode sair do aeroporto. Como o inglês dele é limitado a algumas poucas palavras soltas, demora muito para perceber que seu país sofreu um golpe de Estado e, com isso, todos os acordos internacionais foram cessados, ou seja, o passaporte dele não tem valor nenhum para o burocrático processo de imigração norteamericana.

A primeira tentativa de comunicação dele foi no setor de imigração do aeroporto e o policial questiona: "Sr. Navorski, qual o objetivo da visita?" e ele, por não dominar o código linguístico, limitava-se a pronunciar frases prontas, decoradas e anotadas em um guia de viagens. Em outras palavras, como não consegue fazer-se sujeito do discurso na língua estrangeira, reproduz uma frase feita: "Um táxi, por favor", não havendo êxito na intenção comunicativa. 
Logo no início do filme nos deparamos, na tela de projeção, com Viktor, nossa personagem principal, que, sozinho, no meio da multidão, sente-se desesperado por ver na TV as cenas de guerra em seu país de origem, a Krakozhia. Ele pede ajuda para usar o cartão telefônico, mas como não consegue comunicar-se em inglês, se vê ilhado, isolado, como entre o desejo de outro lugar e o risco do exílio (REVUZ, 1998). A cena que apresentamos, a seguir, é emblemática do sentido da frase pronunciada pelo comandante da segurança do aeroporto para ele: "No momento você não é cidadão de lugar nenhum":

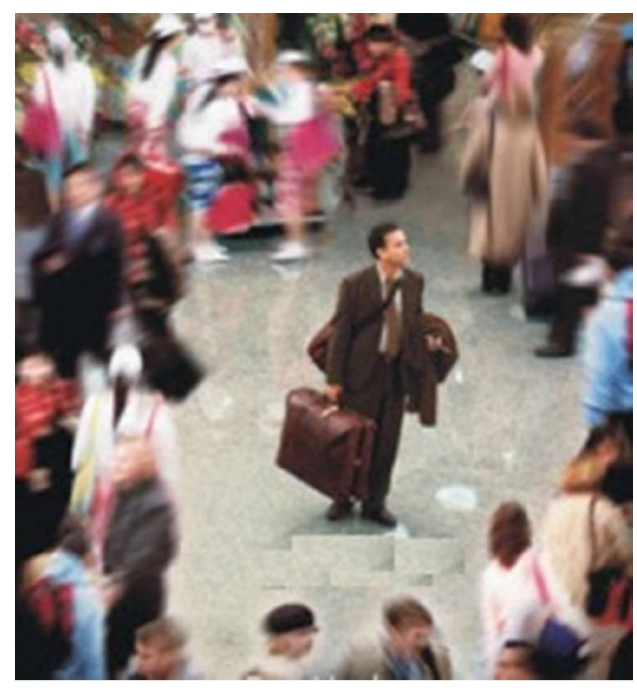

Imagem 8: "No momento você não é cidadão de lugar nenhum".

A relação da língua como porto seguro, como pertencimento a algum lugar e, neste caso, como não pertencer àquele contexto no qual está presente se torna mais latente quanto, ao ouvir o hino de seu país de origem ele busca por televisores para acompanhar as notícias, vê seu país em destruição total e não consegue inteirar-se do que está acontecendo.

Por meio de diversas situações, umas trágicas e outras cômicas, este filme narra algumas das possíveis peripécias pelas quais pode passar um aprendiz de LE em contexto de imersão sem ter tido bom preparo prévio para fazer-se significar na língua estrangeira em contextos reais de comunicação.

Aprender uma nova língua é aprender a significar nesta nova língua (ALMEIDA FILHO, 1993), e é isto que nossa personagem faz. Pena que o processo demora um pouco e Viktor sofre até aprender a ler a intencionalidade implícita nos enunciados linguísticos. Ele está o tempo todo descobrindo como interagir e sobreviver nesse novo contexto. Em cada 
novo dia vê uma oportunidade para acrescentar novas palavras ao seu repertório linguísticocomunicativo para sobreviver, conseguir comida e onde dormir.

Viktor Navorski, é um exemplo de aprendiz de segunda língua que, pela necessidade por conta da imersão no contexto sociolinguístico da língua falada, tem que encontrar meios de se comunicar e interagir. Ele vê notícias do seu país na televisão e, sem entender o que se passa, tenta ler, sem sucesso, as legendas ilustradas na tela. Com isso, ele se vê na necessidade de aprender, com muito esforço, a língua inglesa.

Nossa personagem, pela observação da ação do outro, passa a imitá-lo, criando assim, estratégias para sua sobrevivência. Vemos, na tela de projeção, algumas das etapas que um aprendiz de língua estrangeira passa para adquiri-la, ele tem que aprender a conviver com as diferenças, principalmente linguísticas e ideológicas que nos acompanham. Viktor é um exemplo de aprendiz que, a partir da necessidade, desenvolveu - sozinho - estratégias para a sua própria aprendizagem, por meio do esforço e da busca constante de preservar a própria vida, sem ferir a integridade do outro, nem a sua.

Muitos indivíduos aprendem uma língua estrangeira por afinidade com seus falantes, conforme nos propõe o modelo de aculturação de Schumann (1978). Outros, a exemplo de Viktor Navorski, aprenderam por necessidade, por fazer parte do contexto linguístico do idioma. Portanto, não existe outra maneira de aprender uma língua estrangeira se não for por meio do estudo, da orientação e da dedicação.

A motivação é o fator chave para o desenvolvimento pessoal do indivíduo que busca se aventurar em aprender uma nova língua. Tendo motivação e dedicação para estudar, e autonomia para dinamizar essa aprendizagem, na maioria dos casos haverá bons resultados na sua tentativa de adquirir e aprender uma língua estrangeira.

Aprender uma língua nessa perspectiva é aprender a significar nessa nova língua e isso implica entrar em relações com outros numa busca de experiências profundas, válidas, pessoalmente relevantes, capacitadoras de novas compreensões e mobilizadora para ações subsequentes. Aprender LE assim é crescer numa matriz de relações interativas na língua-alvo que gradualmente se desestrangeiriza para quem a aprende (ALMEIDA FILHO, 1993, p. 15).

A obra cinematográfica em análise apresenta situações que nos permitem trabalhar com os alunos questões como a de que todo enunciado tem uma intencionalidade, um traço cultural e, assim sendo, não basta traduzir ao pé da letra para entender e fazer-se entendido. É possível, portanto, trabalhar com os aprendizes a ideia de que "o que se estilhaça ao contato 
com a língua estrangeira é a ilusão de que existe um ponto de vista único sobre as coisas, é a ilusão de uma possível tradução termo a termo, de uma adequação da palavra à coisa" (REVUZ, 1998, p. 223).

Destacaremos algumas situações do filme que podem ilustrar esta questão: ao ter seus tíquetes-alimentação levados pelo vento e ao perceber que o agente de limpeza os jogou no lixo, Viktor tenta recuperar os cupons. Irritado, o funcionário da limpeza não permite que ele mexa no lixo e pede que ele marque um dia para isso.

Nesta cena, é possível percebermos a falta de conhecimento para poder expressar-se e negociar na nova língua. Aquilo que, num primeiro momento, parece inocência do nosso protagonista, na verdade é falta de conhecimento linguístico situacional, já que ele leva a língua ao pé da letra e não consegue captar questões como a ironia.

Quando o funcionário propõe que ele volte para vasculhar o lixo em Tuesday, ele conta nos dedos para poder saber a qual dia corresponde, fica muito preso em decodificar a língua e não se dá conta das outras sutilezas da comunicação já que, na verdade, o funcionário está enganando ele que, de fato, nunca poderá procurar seus cupons no lixo.

Outra situação muito marcante de como nossa personagem não consegue perceber a força ilocutória por trás de um enunciado. O gerente da segurança do aeroporto, ao perceber que a situação de Viktor demorará para ser resolvida, tenta se livrar do problema influenciando Viktor a fugir, já que assim transferiria o problema para o FBI.

Neste intuito, Dixon, o chefe do serviço de segurança, diz a Viktor: "Vou lhe contar uma coisa... hoje, às $12 \mathrm{~h}$ aquelas portas ficarão sem vigias por 5 minutos", sugerindo, portanto, que nosso personagem principal aproveite a oportunidade e saia do aeroporto. Esta intenção, no entanto, não se concretiza, pois Viktor, além de ser muito honesto, entende tudo ao pé da letra e não consegue perceber que aquele era o objetivo.

Diante das portas de saída do aeroporto que dão acesso a Nova Iorque livres de guardas e tentado a sair, ele ouve o som de uma câmera de monitoramento que se movimenta cada vez que ele se move, o que o faz desistir de sair do aeroporto, já que o comando que sempre foi explícito era o que ele deveria esperar. Ele se aproxima da câmera de segurança e gesticula: "Eu esperar". 


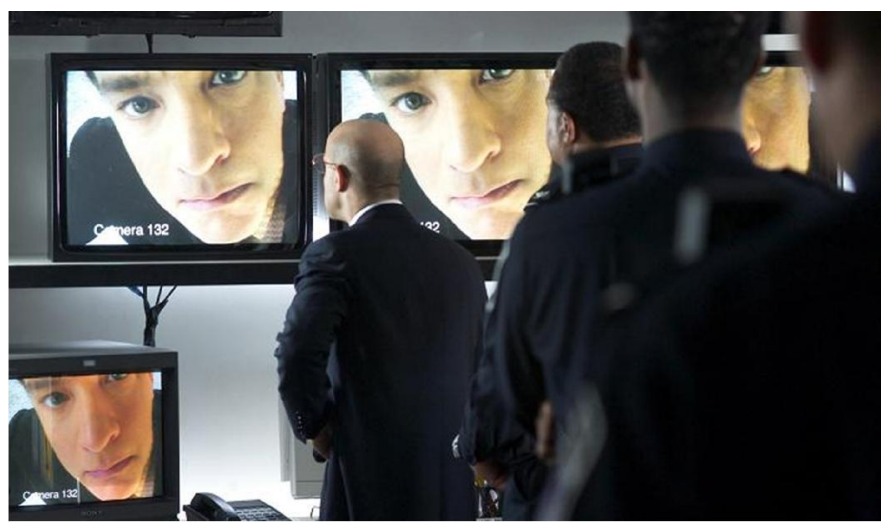

Imagem 9: I wait (Eu esperar).

O aeroporto oferece a nossa personagem um ambiente linguístico rico em linguagens: a verbal, a não verbal, gestos, cores, desenhos, mímicas, sinais luminosos e sonoros, assim como os formulários, cada um de uma cor conforme a solicitação desejada, selos de autorização, faixas no chão para a orientação da fila, placas, as imagens da TV. Dentre as estratégias utilizadas para aprender a língua, e consequentemente, sobreviver, ele compra guias de turismo idênticas na sua língua materna e em inglês e começa, pela comparação e contraste a familiarizar-se com a nova língua.

Com o tempo, sua competência comunicativa intercultural vai se aprimorando e, consequentemente, ele se dá conta das sutilezas e intencionalidades inerentes à língua. Podemos destacar um momento completamente oposto à situação de inocência diante da câmera de segurança (“I wait - Eu esperar..”.) quando Viktor foi chamado para intermediar, como intérprete, uma situação de conflito: um passageiro retido no aeroporto por portar remédios, alegando que seria para o pai. Porém, como a legislação, que Viktor já havia lido não permitia o transporte de remédio para humanos, ao intermediar o conflito, obteve êxito já que, dominando a língua e suas sutilezas, traduziu -intencionalmente errado- que o remédio era para o bode (animal) e não para o pai do passageiro. 


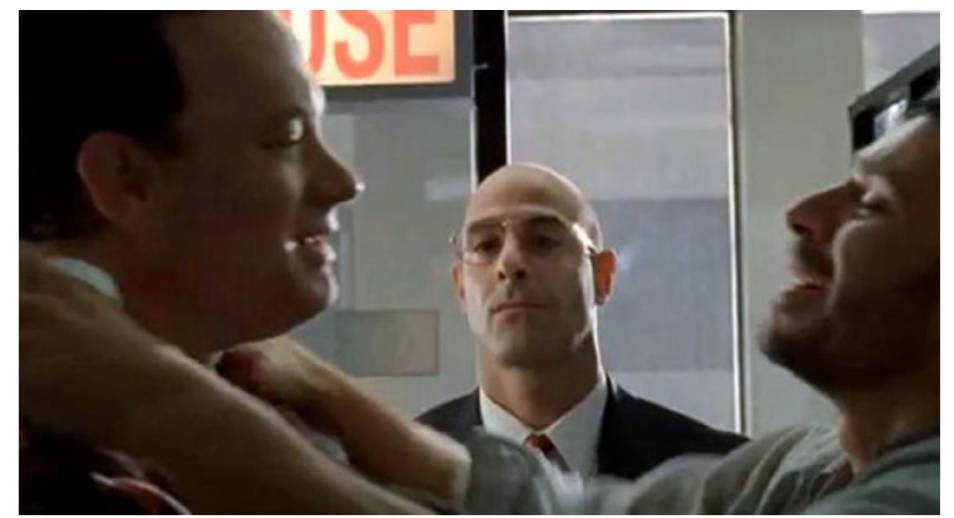

Imagem 10: "... Bode, o remédio é "para o bode', não é 'para o pai', é para o bode!"

A falta de conhecimento linguístico-comunicativo de Viktor, no início do filme, lhe possibilitou entender quase nada do que os oficiais de imigração no aeroporto lhe explicavam, o que de certa forma, neste primeiro momento, acabou funcionando como uma forma de proteção, pois ele se mantém otimista, sem entender a gravidade da situação.

A falta de entendimento do funcionamento da língua e da intencionalidade inerente a ela, não lhe permite entender quando o gerente do aeroporto tenta ajudá-lo a fugir do terminal e entrar nos Estados Unidos ilegalmente. Ele também perde a oportunidade de ganhar asilo político nos Estados Unidos porque interpreta a pergunta muito ao "pé-de-letra", por não saber ainda ler nas "entrelinhas", já que o sentido vai muito além das palavras.

Com o passar do tempo, Victor fala cada vez melhor o inglês e começa a criar sua rede social dentre as pessoas que trabalham no terminal: a bela mulata que carimba vistos, o velho gari de origem indiana, o jovem hispano que transporta refeições para as aeronaves e uma aeromoça com quem Victor estabelece uma história de amor platônico. No mundo de serviços nos Estados Unidos, muita gente com as origens mais diversas se identificam pela condição de ser imigrante, mas terminam se comunicando na única língua que tem em comum, o inglês.

Curiosamente, num momento de muita emoção, Enrique (o transportador das refeições) se direciona a Viktor em espanhol, acidentalmente por certo, mas que revela um grau de intimidade/cumplicidade entre os dois. Viktor não entende nada do que Henrique diz (é claro!), mas há uma disposição à alteridade e a comunicação ocorre.

No que concerne ao processo de ensino-aprendizagem de línguas, foco desta tese, podemos afirmar que a estada de Viktor no terminal pode ser compreendida como um curso intensivo de inglês sem professor, livro didático, plano de aula, ou possibilidades de descansar e se comunicar na sua língua materna em nenhum momento. Ele passa por este teste melhor 
do que a maioria das pessoas, pela sua tranquilidade em aceitar a situação e, ao mesmo tempo, sua criatividade em lidar com ela. A necessidade e, consequentemente, a disposição ao novo e o aprendizado da língua, com certeza, é a chave fundamental para o sucesso desta empreitada.

\subsection{4 "Los Angeles tem 48\% de hispânicos... durante seis anos não nos aventuramos para além da nossa comunidade... estávamos a salvo e felizes"}

O filme Espanglês (BROOKS, L. James. [Dir.] Spanglish. DVD, EUA: 2004) é protagonizado por Flor, uma mexicana que parte para os Estados Unidos junto com sua filha de 12 anos em busca de trabalho.

Esta obra cinematográfica nos permite uma contínua reflexão acerca da língua e seu papel na formação da identidade. O choque de culturas e, consequentemente, o choque linguístico que geraria o espanglês - língua fruto da mistura entre o espanhol (língua materna) e o inglês (língua estrangeira) - não se dá logo no início porque nossa protagonista e sua filha passam anos vivendo em seu porto seguro, o lado "mexicano" de Los Angeles: "Los Angeles tem 48\% de hispânicos... durante seis anos não nos aventuramos para além da nossa comunidade... estávamos a salvo e felizes" (narração da personagem Cristina).

Viver em Los Angeles pode ser interpretado como a busca, em território estrangeiro, pela segurança disponível em sua cultura de origem, devido ao alto índice de hispânicos na região. Durante seis anos, Flor Moreno cria para si o que Krashen (1985) denominaria filtro afetivo alto, em outras palavras, um bloqueio que impede os aprendizes de segunda língua/língua estrangeira de utilizar plenamente os conhecimentos linguísticos que recebem para a aquisição/aprendizagem de um novo idioma.

Nossa protagonista se manteve fiel à sua ideologia de aversão à cultura/língua inglesa até que, certo dia, percebendo que sua filha estava crescendo e seria necessário proporcionarlhe uma vida melhor e com mais oportunidades, decide desbravar o desconhecido e aceita trabalhar na casa de uma família americana, onde se vê obrigada a interagir com uma nova cultura e uma forma diferente de ver o mundo.

O filme destaca o rápido processo de integração da filha à sociedade branca norteamericana ao mesmo tempo em que sua mãe passa por um angustiante conflito interno, desejando que a menina preserve sua identidade mexicana e os valores de sua cultura de origem. 
A questão da identidade linguística de Flor Moreno é bem marcante: ao se arriscar a sair da comunidade hispânica e buscar trabalho fora, passa a conviver com uma família de americanos que não fala espanhol. Ela, por sua vez, não fala inglês e depende da filha para se comunicar com os patrões.

Cristina atua como tradutora da mãe, a qual se sente constantemente ameaçada pela interferência da língua e da cultura inglesa em sua vida e na vida da garota. Por conta disso, Flor Moreno tenta a todo custo preservar sua cultura e, principalmente, sua identidade mexicana. Dito de outra maneira, ela apresenta-se resistente às mudanças, já que "aprender uma língua é sempre, um pouco, tornar-se um outro" (REVUZ, 1998, p. 227).

Neste filme é possível observar que, muitas vezes, o processo de aprendizagem de uma língua estrangeira não acontece de modo natural, gradativo, pois o indivíduo não se aventura a aprender a língua e a apreender seu significado, mantendo-se preso à sua língua materna e sem conseguir se identificar com outros idiomas.

Alguns porão em funcionamento a estratégia da peneira: eles aprendem, mas não retêm quase nada ou muito pouco. Outros adotarão a estratégia do papagaio: sabem de memória frases-tipos, conseguem mais ou menos "exprimir-se" em áreas bem delimitadas (vocabulário técnico, por exemplo), mas não se permitem nenhuma autonomia na compreensão ou na expressão. Para outros, será a estratégia do caos: a língua estrangeira ficará eternamente um acúmulo de termos não organizado por regra alguma, o que os condena a um galimatias ${ }^{83}$ pseudo-infantil mais ou menos eficaz (REVUZ, 1998, p. 225).

Flor Moreno desmistifica a ideia de que todo e qualquer aprendiz tem a mesma facilidade/capacidade de adquirir um idioma estrangeiro, quando em inserção no contexto sociolinguístico da língua. Mesmo cercada de falantes da língua inglesa, a personagem decide estudar o idioma por outras vias e compra um curso caríssimo de inglês, passando a ficar dia e noite com fones de ouvido escutando e repetindo as lições e assistindo aos DVDs do curso à noite. Ao tomar conhecimento do preço pago pelo curso, Cristina fala para a mãe que "a aculturação custou caro", financeiramente falando.

A protagonista nos coloca, ainda, diante de um paradoxo: ela tenta se aproximar da língua, mas continua isolada de seus falantes em situações reais de comunicação. Somente utilizando um curso bastante tradicional ela consegue aprender o idioma, provando que cada método "produz seus alunos brilhantes e seus refratários, de modo a não desvendar e pouco

\footnotetext{
${ }^{83}$ Galimatias: discurso enredado e confuso cujo sentido não se pode captar com facilidade (Dicionário Aurélio).
} 
contribuir na compreensão daquilo que se opõe em movimento para um sujeito dado, ao enfrentar uma língua chamada estrangeira" (REVUZ, 1998, p. 216).

À medida que Flor começa a falar inglês, passa a se revelar como pessoa diante dos demais. É neste momento que ela começa a reconhecer alguns traços comuns com John, o chefe da família da casa em que a moça trabalha. Certa noite, após uma conversa na praia, ele se despede dela com a frase: “It was nice to meet you”, como se eles não se conhecessem já há muito tempo. De fato, para ele foi como se eles tivessem se conhecido apenas no momento em que ela passou a dominar a língua dele.

Schumann (1978) esclarece que a aquisição/aprendizado só ocorre quando há integração psicológica e social do aprendiz com o grupo de falantes da língua estrangeira. Esta integração só pôde acontecer para Flor, de fato, quando ela se permitiu envolver afetivamente com John, já que até aquele momento ela não admitia qualquer tipo de aculturação. Pode ser que este fato justifique o motivo pelo qual Cristina aprendeu com tanta facilidade o inglês, a ponto de servir como tradutora/intérprete para a mãe: a garota não alimentava, em sua mente, o distanciamento e a aversão ao outro da mesma forma que sua progenitora.

A partir da interação com os falantes reais da língua, Flor começou a aprender, além da língua, os hábitos da cultura alheia. Neste sentido, podemos afirmar que, ao cozinhar com John, junto com a troca de experiências, havia o intercâmbio de práticas culturais, inicialmente ligadas à aculturação de Schumann (1978), mas com potencial para posteriores práticas interculturais. $\mathrm{O}$ fator acionador para a aprendizagem de qualquer idioma passa a ser, portanto, o querer, o estudo, a persistência e o engajamento do aprendiz.

O estranhamento diante do novo universo vivenciado por Flor é demonstrado pelo medo que ela tem de que sua filha já esteja tão acostumada com todas as regalias de uma vida americanizada (estereotipada pelas personagens norte-americanas) e a consequente perda da sua identidade: "o $e u$ da língua estrangeira não é, jamais, completamente o da língua materna (...). Nem todo mundo está pronto para essa experiência. Ela representa para alguns aprendizes um perigo que eles evitam (...) evitando aprender a língua” (REVUZ, 1998, p. 225).

O termo língua materna enquanto porto seguro (origem, identidade, gestação, criação), é reforçado pela personagem Flor: ela sustenta suas raízes e não deixa a filha esquecer-se de 
onde tinham vindo, quais eram suas origens. Durante muito tempo ela foi "o México" para Cristina.

A questão da identidade, de não identificar-se com outro modo de ser, de estar, de viver, tona-se, portanto indiscutível. Nossa língua materna sempre será nossa identidade, o espelho e o reflexo da nossa cultura, de nossas raízes, e não será perdida, nem substituída por um novo conhecimento. $\mathrm{O}$ ambiente ao qual o aprendiz se expõe para sua aprendizagem tem que ser visto como um campo de extensão, no qual aprendiz e aprendizado caminham e evoluem juntos. O indivíduo tem que querer aprender a língua e, para tanto, é recomendável que crie alternativas próprias de estudo, sendo seu principal motivador e autogerenciador de seu processo de aprendizagem.

Na última cena do filme Flor retira Cristina à força da piscina da casa da família norteamericana e comunica que irá tirá-la da escola particular (mantida pela família norteamericana). Trata-se do ápice do conflito do filme: a jovem precisa decidir com que lado se identifica mais, tendo que optar entre a família branca norte-americana e a mãe mexicana.

Neste ponto a língua funciona como elemento de ofensa e transgressão. A mãe já tem um nível razoável de clareza do inglês e, enquanto andam pela rua, a filha grita para ela " $I$ can't believe you do this to me, I can't believe you do this to me", mas em seguida percebe que quebrou todos os códigos de comportamento de uma filha mexicana, desmoralizando sua mãe em público. Os dois quilômetros que andam em silêncio até o ponto de ônibus parecem ser a mais longa caminhada de suas vidas. No final do filme, ao se reconciliarem, a filha volta a se dirigir à mãe em espanhol.

Esta obra lança luz sobre as dificuldades que as pessoas têm de se comunicar, destacando situações de línguas em contato e a relação entre língua e identidade, bem como a aprendizagem de uma língua outra em contexto de imersão, quando a necessidade de sobrevivência em uma nova comunidade linguística torna-se o principal elemento motivador.

\subsubsection{Numa grande cidade em que, normalmente, ninguém se importa com ninguém, ele se permitiu uma experiência intercultural}

$O$ visitante (MCCARTHY, Thomas [Dir.] The visitor. DVD, EUA, 2007) nos apresenta Walter Vale, de 60 anos, professor de economia na Universidade de Connecticut, que perdeu a paixão pelo ensino e leva uma vida rotineira, tentando preencher o vazio da sua 
existência aprendendo a tocar piano, mas sem grande sucesso. Trata-se de um senhor viúvo e pai de um filho que mora em Londres. Nosso protagonista é professor e também se diz escritor, duas atividades diretamente relacionadas ao convívio com seres humanos, porém, ele se apresenta como uma pessoa intolerante e adepta ao isolamento, pois sempre está só e mesmo quando se encontra na presença de outras pessoas, prefere ficar em silêncio.

Nosso personagem apresenta um filtro afetivo alto que bloqueia o contato com os outros. A vida no nosso protagonista começa a mudar quando ele é forçado a deslocar-se a Nova Iorque para uma conferência, descobre que o seu apartamento foi ocupado por um jovem casal de imigrantes ilegais (Zainab, do Senegal e Tarek, da Síria). Walter acaba permitindo que os dois jovens fiquem temporariamente com ele.

A obra nos apresenta temas contemporâneos, como a imigração ilegal, solidão, tolerância, amizade e aceitação, bem como o choque de culturas. Em outras palavras, um casal de imigrantes consegue dar cor à vida cinzenta e rabugenta de um senhor solitário, amargurado, e frustrado por não conseguir tocar piano. Aos poucos, Walter vai recuperar a alegria de viver, tornando-se amigo de Tarek.

A arte tem o potencial de transpor barreiras linguísticas e unir as pessoas e, no caso da obra em análise, não seria diferente, Walter, que era de hábitos solitários, ao encontrar-se com Tarek inicia uma mudança em seu comportamento. Apesar de serem de universos culturais diferentes, os dois tem em comum o gosto pela música. Walter acaba se interessando pela música africana e começa a aprender, com a mediação de Tarek, a tocar djembê, uma espécie de tambor.

A cultura, segundo a perspectiva sociocultural, não é algo pronto, como uma receita, mas um "palco de negociações” (REGO, 1995, p. 55), no qual o indivíduo negocia e constrói sentidos compartilhados, como a língua, as crenças, as tradições. Neste sentido, para conhecer uma cultura, o indivíduo precisa permitir envolver-se por ela para que os intercâmbios que proporcionarão o aprendizado ocorram.

Quando a polícia prende Tarek sob a acusação injusta de ter pulado a catraca do metrô e descobre que ele é um imigrante ilegal e ameaça deportá-lo, Walter empreende uma verdadeira cruzada para salvar o amigo, mas acaba não obtendo êxito. O filme nos dá um exemplo de como a música pode unir as pessoas e nos faz repudiar as linhas imaginárias que compõem as fronteiras entre os países. 
Podemos afirmar que entre Walter e Tarek estabelece-se uma relação intercultural. Já entre Walter e Zainab (a noiva que vivia com Tarek) há certo relativismo cultural, ela o vê com desconfiança e não interage de forma que se realizem intercâmbios culturais e sejam criados laços de amizade. Assim sendo, após a prisão do noivo, ela deixa o apartamento do professor.

O relativismo cultural também pode ser notado no comportamento de Mouna Khalil, em relação à nora, Zainab, ao conhecê-la, a mãe de Tarek estranha o fato de ela ser negra, "muito negra", nas palavras da nossa personagem. Embora haja este estranhamento inicial, as duas convivem e se respeitam, porém, não há troca de experiências culturais.

Destacamos a última cena do filme, com Walter sentado tocando tambor na estação da Broadway, como se fosse uma explosão, um desabafo forte da representação do sonho americano e do sonho de vida banido de Tarek e sua mãe.

\subsubsection{Cada vez mais eles conversam, cada um em seu idioma, já que nenhum dos dois fala bem a língua inglesa}

Descobrimos, recentemente, a possibilidade de trabalhar com o filme Mil anos de orações (WANG, Wayne [Dir.], Mr. Shi, DVD, EUA, 2007) para abordar o complexo processo de ensinar e aprender línguas. $\mathrm{O}$ filme leva à tela a temática do choque cultural e nos apresenta Sr. Shi que, ao decidir sair da China para visitar sua filha Yilan, que mora nos Estados Unidos e se divorciou recentemente, fica com um pé no Oriente e outro no Ocidente. Há muitos anos sua filha mora em San Francisco e agora precisa adaptar-se à companhia do pai, que é adepto ao comunismo.

O Sr. Shi tenta ajudá-la a superar o momento, mas cada vez que tenta descobrir a razão do divórcio percebe que Yilan faz de tudo para evitá-lo. Neste período ele conhece uma iraniana idosa, a quem chama de "Madame". Cada vez mais eles conversam, cada um em seu idioma, já que nenhum dos dois fala bem a língua inglesa.

O filme apresenta, em vários momentos, as estratégias que Sr. Shi e "Madame", sua interlocutora iraniana, lançam mão para que haja comunicação -apesar das enormes barreiras da língua.

Dessa forma, temos um paradoxo: pai e filha conhecem a mesma língua mas quase não há interação, reinando a incomunicabilidade com longas pausas silenciosas que só acentuam o clima de hiato interpessoal a que as personagens são submetidas, mostrando que a difículdade 
de dialogar vai muito além do idioma. Por outro lado, entre o Sr. Shi e a Sra. Iraniana a língua é o menor dos problemas de comunicação, o que reforça o nosso argumento de que aprender uma nova língua vai muito além de questões linguísticas.

\subsection{Considerações}

Nosso trajeto, neste capítulo, consistiu em relacionar o complexo processo de ensinoaprendizagem de línguas com algumas de suas representações cinematográficas. Finalizamos relacionando os filmes e retomando a importância, para a tese, de contemplar teoria e prática na aquisição/aprendizagem de línguas, bem como o papel do cinema como representação nesse processo e a intenção de - ao explicitar algumas das variáveis inerentes - auxiliar professores e alunos envolvidos no processo.

Neste sentido, temos consciência de que a aprendizagem de línguas estrangeiras esbarra na dificuldade que há para cada um de nós, não somente de aceitar a diferença, mas de explorá-la, de fazê-la sua, admitindo a possibilidade de despertar os jogos complexos de sua própria diferença interna, da não coincidência de si consigo, de si com os outros, de aquilo que se diz com aquilo que se desejaria dizer (REVUZ, 1998).

Os conceitos-chave alteridade, intencionalidade, interculturalidade e identidade analisados nos filmes são determinantes quando falamos no ensino-aprendizagem de língua estrangeira. Faz-se necessário proporcionar aos alunos atividades de mediação apropriadas para discutir estas questões, sendo o professor um mediador intercultural capaz de facilitar o processo.

A prática da alteridade constitui-se em um dos principais elementos facilitadores da aquisição/aprendizagem de uma língua estrangeira. Quando o aprendiz tem consciência e reconhece a importância de interagir e compartilhar experiência com o outro, a curiosidade pode facilitar a disposição, responsabilidade e dedicação em constituir-se enquanto outro.

A interculturalidade é uma visão progressista das culturas e da sua gente. É estudar, discutir e respeitar a cultura do outro como se esta fosse uma extensão da sua própria cultura. As teorias relacionadas ao complexo processo de aquisição/aprendizagem de línguas nos mostram que não existe uma única e inalterável resposta para a pergunta "Como se aprende uma língua?" e, concomitantemente, não nos aponta um caminho para esse fim. A teoria e a prática, contudo, junto com as experiências em sala de aula, nos mostram cada vez mais, que esse é um processo totalmente particular e subjetivo. 
Nossa leitura dos filmes aqui apresentados trouxe, ademais de informações sobre o processo de aquisição/aprendizagem de línguas, conhecimentos básicos, porém relevantes, a respeito dos fatores internos e externos que influenciam o indivíduo no momento de adquirir/aprender uma língua estrangeira. Pois são fatores determinantes e que devem ser considerados na busca por potencializar o complexo processo de ensino-aprendizagem de línguas.

As diferentes representações apresentadas e discutidas nos mostram que não existe uma única maneira de adquirir/aprender uma língua estrangeira, o que vai ao encontro das reflexões de Hall (2011), que nos apresenta os riscos dos perigos do excesso de simplificação ao definir o "bom aluno de línguas", já que devemos reconhecer que há mais de uma maneira para ser um aprendiz de línguas bem sucedido e que muitos são os fatores que interagem na questão. Dentre eles, a metodologia, os recursos, as diferenças individuais, o contexto de aprendizagem, características do professor, aspectos relativos à língua a ser aprendida, os processos cognitivos dos aprendizes.

Não tivemos a intenção de esgotar todas as análises possíveis nem reduzir as produções aos aspectos aqui abordados, mas nos guiamos por aquilo de específico que cada obra pôde apresentar para a compreensão do processo de aquisição/aprendizagem de uma língua estrangeira ${ }^{84}$.

Nosso próximo capítulo apresenta a análise dos dados coletados com o grupo focal nas oportunidades de reflexão proporcionadas com a mediação do cinema ao longo do semestre letivo 2013.2.

\footnotetext{
${ }^{84}$ Os aspectos formais da aquisição/aprendizagem de línguas também foram abordadas em sala ao longo do semestre 2013.2.
} 
CAPÍTULO 6 ANÁLISE E DISCUSSÃO DOS DADOS 
Quanto mais me assumo como estou sendo e percebo a ou as razões de ser, de por que estou sendo assim, mais me torno capaz de mudar, de promoverme, no caso do estado de curiosidade ingênua para o de curiosidade epistemológica (FREIRE, 1996, p. 39).

Acreditamos ser necessário que os cursos de (trans)formação inicial ou contínua insiram os atores num processo de elicitação e a posterior conscientização das crenças, bem como na reflexão crítica sobre as mesmas. Certamente esta ação crítica-reflexiva poderá ajudar o futuro professor e o professor de línguas em (trans)formação contínua a compreender, com mais nitidez, o complexo processo de aprender/ensinar uma LE (SILVA, 2011, p. $53)$. 
Este capítulo apresenta a análise dos dados coletados com o grupo focal durante as oportunidades de reflexão proporcionadas ao longo de dois componentes curriculares e um curso de extensão, ofertados pelo autor desta tese, no segundo semestre letivo de 2013 (outubro de 2013 a março de 2014) ${ }^{85}$. Enfocamos os dois principais eixos desta investigação, ou seja, como os participantes compreendem o processo de aquisição de uma língua estrangeira, bem como percebem a questão da unidade e diversidade do E-LE e suas implicações didáticas, todas essas reflexões mediadas pelo cinema. Buscamos, também, apresentar a análise de forma a responder às nossas perguntas de pesquisa:

- Se e como se transformam, com a mediação do cinema, as crenças de professores de espanhol em formação inicial acerca do processo de aquisição/aprendizagem da língua estrangeira e do tratamento da unidade e diversidade linguística no ensino de espanhol-língua estrangeira para brasileiros?

Duas perguntas se desdobram de nosso questionamento principal:

- A partir do discurso dos participantes, quais são os indícios da influência dessas crenças na forma como eles se engajam em sua formação profissional?

- Quais as contribuições do cinema, enquanto artefato semiótico mediador, no processo de desenvolvimento do aprendiz reflexivo?

Buscando responder à estas inquietações, nossas discussões estão divididas de forma a apresentar as principais crenças de cada umas das participantes, que estão organizadas em dois blocos, o primeiro com foco no complexo processo de aquisição e o segundo na percepção delas em relação à questão da unidade e diversidade da língua espanhola, a prática da alteridade e da mediação cultural no ensino deste idioma para brasileiros, tendo como pano de fundo o contexto da integração latino-americana. Apresentaremos as possíveis crenças das participantes, bem como os prováveis indícios ou não de (res)significação e (re)construção.

Para facilitar a compreensão do leitor, os excertos citados sofreram correção ortográfica, mas sem alteração no conteúdo. $\mathrm{Na}$ análise, optamos por apresentar as crenças mais recorrentes, sem pormenorizar uma averiguação exaustiva de cada participante. Não temos por objetivo comparar as participantes, pois sabemos que as pessoas são diferentes, já que o mundo é heterogêneo por natureza e cada ser humano possui seu esquema de cognição moldado por suas vivências/experiências anteriores.

\footnotetext{
${ }^{85}$ Conforme destacamos anteriormente, por conta de um período de greve, o semestre letivo não correspondeu ao segundo semestre de 2013.
} 
O que faremos em alguns momentos é, inevitavelmente, comparar a forma como cada uma delas, a partir de sua formação e experiências anteriores, reagiu às atividades de reflexão propiciadas ao longo do semestre. Entendemos que as concepções e crenças são dinâmicas e nossa investigação enfocou um contexto específico de formação inicial, que reflete um dado momento da trajetória destas participantes.

A intenção da pesquisa não foi provar hipóteses construídas previamente, mas sim retratar as crenças expressas pelas participantes em diferentes oportunidades ao longo do semestre, bem como averiguar as contribuições do cinema para a reflexão e para o desenvolvimento de suas cognições enquanto professoras em formação.

Nossa ênfase não foi em dividir as crenças em momentos estanques, como antes, durante e depois dos componentes curriculares e do curso de extensão, já que acreditamos que o próprio fato de participar dos dois componentes curriculares e do curso de extensão já poderia estar influenciando, (re)significando ou (re)construindo suas crenças. Ao analisarmos as contribuições das oportunidades propiciadas, buscamos enfocar o potencial de reflexão nas atividades promovidas com ênfase na visão e compreensão das participantes, de forma a relacionar aspectos que poderão ser aprimorados em nossas práticas futuras.

Para compor nosso grupo focal, contamos com Ana Cecília, Isabelly e Lourdes Maria $^{86}$, que serão apresentadas a seguir. $\mathrm{O}$ critério para a seleção das participantes foi que elas tivessem frequentado com assiduidade os dois componentes curriculares e o curso de extensão, todos oferecidos ao longo do semestre 2013.2 e tivessem preenchido o termo de consentimento livre e esclarecido, dispondo-se a colaborar com a investigação.

\subsection{Ana Cecília}

Ana Cecília tem 24 anos e é membro de uma família grande, composta por nove irmãos. Ela é brasileira, casada, tem um filho, atualmente mora na zona rural. Dedica-se à casa, ao marido, ao filho pequeno e aos estudos. Seus pais têm o ensino fundamental incompleto e o marido estudou até concluir o ensino médio. Ela estudou em escola pública durante a vida toda, frequentou cursinho pré-vestibular durante um semestre, não conhece nenhuma língua estrangeira além do espanhol e nunca foi ao cinema, teatro, museu, ou

\footnotetext{
${ }^{86}$ Os nomes adotados são fictícios e foram escolhidos pelas próprias participantes da pesquisa.
} 
shopping. Não tem computador e nem acesso à internet em casa. Ela relata assistir a filmes, em casa, ao menos uma vez por mês.

Apresentaremos, agora, a autobiografia de nossa participante, que será comentada logo em seguida:

Minha história com a língua estrangeira começa numa escola pública na quinta série do ensino fundamental II, quando eu tinha 12 anos, foi o meu primeiro contato com ninguém falando ou escrevendo, era a língua inglesa, quase não havia fala, só escrita e pouca aprendizagem, me lembro que aprendi do zero até o vinte, as saudações, a professora só explicava gramática o tempo todo mais eu não entendia, passei da quinta série ao ensino médio vendo praticamente a mesma coisa, mas eu confesso que não decorei nem sequer uma frase, meus colegas me ajudavam a fazer as provas e por isso eu passava de ano. Quando eu estava na escola ainda não havia a implantação do espanhol nas escolas, por isso eu só estudava a língua inglesa, não se falava no espanhol, e eu me lembro que a minha primeira ligação com o espanhol foi por falta de opção. Estávamos fazendo a inscrição para o vestibular e creio que não sabia o que fazer, fui para a inscrição pensando, lembro que tinha quatro opções, matemática, ciências contábeis, português e espanhol e estava quase me decidindo entre português e espanhol pois eu não gosto de números.

Saímos da escola, a minha amiga e eu para ir fazer a inscrição para o vestibular. Quando íamos pela rua encontramos mais três amigas que já tinham feito a inscrição e todas tinham feito para o espanhol, e mandaram a gente fazer também, pois segundo elas, era bem menos concorrido, era uma coisa diferente e depois as escolas iam ter aula de espanhol, então íamos ter emprego. Assim fizemos todas nós, só que só eu fui fazer a prova do vestibular. Depois de alguns dias saiu o resultado e eu tinha passado. Começaram as aulas do curso de Letras-Espanhol e minha primeira aula foi de Estágio Supervisionado I, com uma professora que começou falando em espanhol e querendo que os alunos falassem, pois segundo ela, todos os alunos dela eram obrigados a falar em espanhol, mesmo sendo do primeiro período. Falávamos muito mal mas para ela estava bem, já que era o início de um longo caminho. O curso foi passando, fui me desenvolvendo mais até engravidar.

Depois eu engravidei, e foi difícil conciliar os dois pois eu ficava muito cansada e não tinha vontade de estudos e, por isso, eu atrasei os estudos e tranquei o curso. Depois de um tempo que meu filho tinha nascido eu voltei para continuar o curso, foi difícil pois eu estava há muito tempo sem estudar e como eu estava no quarto período os professores já não eram tão compreensivos e eu estava como se fosse no primeiro período, meus colegas já não eram os mesmos, era uma turma tão estranha como a língua espanhola.

Diante de tudo isso eu comecei a reler os textos dos semestres anteriores para poder conseguir acompanhar o quarto período e foi muito difícil, até eu conseguir pegar o ritmo de estudos novamente.

Eu gosto muito da língua espanhola, gosto de falar e escrever, mas confesso que tenho um pouco de vergonha de falar, sei que para ser uma professora de língua espanhola eu tenho que saber falar, escrever e ter muita segurança do que estou fazendo e muitas vezes sei, mas fico presa em mim mesma e isso é algo que eu sei que preciso mudar.

Em relação ao que sei da língua espanhola, sei que é muito pouco para uma futura professora e sei que preciso estudar mais e mais (Autobiografia de Ana Cecília, elaborada no final do semestre letivo).

Ana Cecília teve o primeiro contato com a língua estrangeira no ensino fundamental II da escola pública. A experiência com o inglês não foi satisfatória, nossa participante não 
entendia os conteúdos e, mesmo com a repetição do mesmo conteúdo durante todos os anos, chegou até o final do ensino médio sem aprender nada, contando com o auxílio dos colegas no momento de fazer as provas.

O encontro da Ana Cecília com o espanhol deu-se pela influência de amigos, diziam que além do curso de Letras-Espanhol ser pouco concorrido, haveria muita oportunidade de trabalho. A trajetória dela durante a graduação foi conturbada, sempre encontrou muita dificuldade em acompanhar o curso, teve uma gravidez, precisou trancar o curso, sentiu dificuldade ao retornar, "pois eu estava há muito tempo sem estudar (...) os professores já não eram tão compreensivos e eu estava como se fosse no primeiro período, meus colegas já não eram os mesmos, era uma turma tão estranha como a língua espanhola”.

Com o passar do tempo, aquilo que era uma falta de opção passou a ser algo que despertou a atenção de Ana Cecília, que hoje gosta muito do curso. Ela relata que das quatro habilidades, a maior dificuldade está em falar. Nossa participante apresenta consciência das suas limitações e argumenta que tem se engajado buscando estudar e se empenhar para desenvolver-se como educadora.

\section{A respeito do processo de aquisição/aprendizagem do E-LE}

No início do componente curricular "Linguística aplicada ao ensino da língua espanhola", sem nenhum contato prévio com a teoria, os participantes assistiram às produções cinematográficas que retratavam o processo de aquisição/aprendizagem da língua estrangeira.

Durante a exibição dos filmes, registraram suas impressões em logs e desenvolveram várias atividades a respeito dos comportamentos, hábitos e atitudes das personagens cinematográficas em relação à língua e ao(s) Outro(s). Ana Cecília fez poucos registros e todos eles com conteúdos muito genéricos, conforme podemos observar nos excertos:

[Excerto 114]

Xavier e seus amigos, cada um de um país diferente, vivendo na mesma casa, onde cada um com a sua língua, com os seus costumes, mas que se entendem um ajudando aos [Excerto 115] outros em frases, palavras (Log do filme Albergue Espanhol, Ana Cecília).

O chinês e Roberto começam a ter uma comunicação por meio de gestos e um ajudando ao outro... (Log do filme Um conto chinês, Ana Cecília). 
A superficialidade das reflexões também pode ser observada na atividade realizada após a exibição do filme "O terminal", em que a participante se ateve ao sentido moral da história e não numa reflexão no sentido da educação linguística propriamente dita:

[Excerto 116]

"O terminal" te ensinou alguma coisa a respeito do processo de ensinar e aprender linguas? Comente.

Sim. Quando Victor é chamado para traduzir a conversa de um passageiro com o diretor do aeroporto e tem que explicar para quem são os remédios que o passageiro está transportando e explica que não são para o pai do passageiro e sim para o bode, enganando o diretor já que remédio para animais era permitido e para humanos não. Este trecho mostra a importância de se conhecer outra língua, pois se o diretor soubesse o outro idioma não teria sido enganado.

Você pôde extrair do filme alguma "lição" que pode contribuir para sua forma de aprender E-LE? Comente.

Sim, as amizades que podemos fazer diante de determinadas situações e foi isso que Viktor fez. Ele aprendeu outra língua e teve assim muitos novos conhecimentos de novas culturas.

Suas estratégias, hábitos e atitudes em relação à aquisição/aprendizagem da língua espanhola foram, de alguma forma, alteradas a partir das experiências com os quatro filmes assistidos até agora (Um conto chinês, O terminal, Espanglês, Albergue espanhol)? Justifique.

Espanglês e O terminal. Espanglês quando Flor vai aprender inglês por si só, para não ficar esperando pela sua filha para traduzir tudo sempre para ela.

O Terminal quando Victor faz amizade com pessoas de países diferentes cria amizades, aprende língua e se apaixona.

(Ana Cecília - Atividade após a exibição de $\mathrm{O}$ terminal - quarto filme a respeito do processo de aquisição/aprendizado de LE - 04/12/2013)

A participante se limita a narrar as histórias contadas e apreendeu apenas alguns conceitos ligados ao senso comum: i) quando pessoas de línguas diferentes convivem um vai ajudando o outro com gestos, palavras; ii) é importante conhecer outras línguas para não ser enganado; iii) podemos fazer amizades em diversas situações de adversidade; iv) é importante aprender uma língua para não ter que ficar o tempo todo dependendo de alguém para traduzir; e não se engaja numa reflexão linguística a respeito dos processos de aquisição/aprendizagem representados em tela.

As atividades realizadas após a exibição do filme Espanglês também ilustram que a participante, talvez pela pouca experiência com produtos audiovisuais, não estava entendendo bem as atividades que estavam sendo trabalhadas:

[Excerto 117]

Relate o que dos três filmes [Um conto chinês, Albergue espanhol e Espanglês] assistidos até agora tem de diferente em relação à representação do processo de aquisição/aprendizagem de uma língua estrangeira.

A questão da aquisição/aprendizagem. Apenas no último filme ao meu ver houve este aprendizado. 
Esses filmes mudaram de alguma forma a sua visão a respeito de como se aprende uma lingua? Sim ou não? Justifique.

Sim. Pois não se aprende outra língua apenas em uma Universidade, na escola ou em curso de idiomas. Podemos aprender apenas na convivência.

Você, como aprendiz de língua estrangeira, se identificou com algum dos personagens mostrados nos três filmes exibidos até agora? Qual? Justifique.

Espanglês. Flor, escutando música, assistindo programas de TV (Ana Cecília - atividade feita após a exibição de Espanglês).

Podemos citar que houve, com a mediação do cinema, a construção de uma crença positiva quando Ana Cecília relata que os filmes assistidos possibilitaram a ela uma nova visão a respeito de como se adquire/aprende uma LE e cita ser possível aprender em ambientes formais de ensino-aprendizagem e também fora deles, na convivência.

Já no momento em que ela comenta ter se identificado com Flor Moreno, protagonista do filme Espanglês, pois a personagem aprende escutando música e assistindo aos programas de TV a participante nos dá indícios da falta de hábito de apreciar a cultura audiovisual, pois ela não entendeu a maior parte do filme. Flor Moreno, na verdade, nos coloca diante de um paradoxo, estava vivendo no país da língua estrangeira e não se permitia o contato com os outros e, dessa forma, ao invés de aprender com falantes reais comprou um método audiovisual e aprendia, via repetição, pela TV. Neste trecho do filme a narradora, Ana Cristina, filha de flor argumenta "aculturação custa caro".

Muito tempo depois, durante uma aula teórica, Ana Cecília teve um insight de que não tinha conseguido entender os filmes de acordo com os objetivos propostos. Após a exibição de todos os filmes com a temática da aquisição/aprendizado, começamos as discussões confrontando filmes, teorias e a experiência deles enquanto aprendizes de forma a promover momentos de reflexão propícios à (re)significação e (re)construção de crenças, visando desconstruir estereótipos negativos e potencializar o processo de aquisição/aprendizado dos participantes, nosso intuito era que eles percebessem que a aquisição/aprendizagem vai muito além da ordem do linguístico e que não existe a melhor forma de adquirir/aprender.

Dessa forma, os alunos apresentaram, em grupos, seminários a respeito das principais teorias/modelos de aquisição/aprendizagem de línguas. Durante os seminários, os alunos eram incitados a relacionar as teorias apresentadas com as suas vivências como aprendizes e com os conteúdos discutidos ao longo dos filmes. Apresentamos, a seguir, a transcrição do trecho da aula em que Ana Cecília toma consciência dessas reflexões. Estávamos já quase no final da aula em que foram apresentados e discutidos os temas Teoria Behaviorista e Modelo Monitor de Krashen: 
[Excerto 118]

Pesquisador: Eu achei legal aquela hora que você falou, que você falou, que mudou a sua forma de ver os filmes.

Ana Cecília: Sim, porque, eu tava dizendo inclusive à mãe: 'o professor tá passando uns filmes, pra quê isso?' eu não tava entendendo,

Pesquisador: O que que os filmes tinham a ver com o processo de aquisição?

Ana Cecília: Sim, eu não tava entendendo, eu tava assim, tava vendo assim: ele [o personagem de cada filme] quer aprender ou não quer aprender, só isso... eu não tava entendendo $\left(^{*}\right)$ eu tava fazendo assim: $\left({ }^{* *}\right)$ pronto, ele já aprendeu [a língua estrangeira].

Pesquisador: Você estava associando os filmes com a sala de aula: quer ou não quer aprender...

Ana Cecília: É, a situação, por exemplo, [um conto chinês] a pessoa tava passando por aquela situação, eles tiveram que conviver...

Maria José: Eu já tinha assistido o terminal pela quinta vez, mas cada vez que a gente assiste é diferente, você observa e aprende coisas diferentes.

Ana Cecília: Mas nem o filme eu tava entendendo

Pesquisador: Mas era o seu jeito de olhar os filmes?

Ana Cecília: É, eu não tava vendo dessa forma, de observar, perceber, eu só tava olhando, tá, eles tinham que conviver com aquela língua, e daí? o que é que tem a ver? Eu não tava observando essas questões que agora com os seminários está despertando o meu olhar,

Pesquisador: Se você fosse assistir hoje e analisar hoje, depois da teoria, você já ia assistir de outro jeito?

Ana Cecília: Sim, com certeza, pois agora está fazendo mais sentido para mim e consigo relacionar as teorias com os filmes e com o meu próprio aprendizado (Trecho da aula ministrada em 06/12/2013).

Este momento representa, para Ana Cecília, um despertar da mente para novas possibilidades de (re)significação e (re)construção de crenças. O discurso dela, quando se dá conta de que não estava assistindo e olhando para os filmes da maneira mais proveitosa, de forma a potencializar as estratégias, hábitos e atitudes em relação ao processo de aquisição/aprendizagem da língua estrangeira, indica uma tomada de consciência, via reflexão crítica, que pode possibilitar a abertura de sistema de crenças para inspeção consciente. Ou seja, as experiências com o cinema e com as atividades de reflexão cumpriram, para esta participante, um papel relevante, ainda que com efeito retardado, ao longo do semestre.

Ana Cecília não tem um bom domínio linguístico do E-LE e tem consciência disso:

[Excerto 119]

Pesquisador: Você já se sente capaz de fazer/desempenhar razoavelmente bem em língua espanhola?

Ana Cecília: Dentro do possível, é claro que preciso me preparar mais um pouco (Entrevista realizada após a finalização do semestre 2013.2).

Diante disso, a participante tem uma postura positiva de reconhecer suas limitações e se empenhar positivamente na superação delas. Neste sentido, Ana Cecília apresenta uma crença positiva de que devemos nos empenhar ao máximo para falar sempre em espanhol: 
[Excerto 120]

Pesquisador: Quais fatores atrapalhariam ou dificultariam a aprendizagem de língua espanhola? Por quê?

Ana Cecília: Quando não se fala o espanhol dentro da sala de aula, já que em muitos casos é o único contato que o aluno tem com a língua.

Pesquisador: Qual é a sua ideia de aula de língua espanhola bem sucedida?

Ana Cecília: Quando falam em espanhol, ou se não sabe falar pelo menos tentam falar. E escreve em espanhol e estar sempre tentando se aperfeiçoar dentro do possível.

Pesquisador: Como seria o perfil de um bom professor de língua espanhola?

Ana Cecília: Falar e escrever em espanhol e incentivar os alunos a fazer o mesmo (Entrevista realizada após a finalização do semestre 2013.2).

Esta crença positiva é sustentada pelas ações da nossa participante, já que a maior parte das atividades realizadas por ela em 2013.2 foram feitas em espanhol. Ainda que apresente um baixo domínio linguístico, ela se empenha para utilizar ao máximo a língua que pretende aprender.

\section{A percepção do tratamento da unidade e diversidade na língua espanhola}

Ana Cecília participou da análise preliminar do contexto, realizada em dezembro de 2012 com 90\% dos alunos de Letras-Espanhol do campus. Naquela ocasião, os formulários não eram identificados, porém, posteriormente a participante localizou no pacote reunido e identificou o seu questionário ${ }^{87}$. Nele, havia uma pergunta: "quando você fala em espanhol, você se sente como um falante: ( ) Latino americano ( ) espanhol. Comente, se julgar necessário". Dez meses depois, ou seja, em outubro de 2013, logo no início do componente curricular "Linguística Aplicada à Língua Espanhola" aplicamos uma sondagem em que aparecia a mesma pergunta. Observamos que a nossa participante, nas duas ocasiões, respondeu que se sentiria melhor falando como um espanhol, e não comentou a sua resposta. Em entrevista, quando questionada a respeito das justificativas para a escolha, ela argumenta:

[Excerto 121]

Ana Cecília: Eu coloquei que eu falava gostaria de ser reconhecida, quando falando da a língua espanhola, como uma espanhola, porque assim, é assim, desde quando eu pensei em fazer o vestibular para espanhol eu dizia 'eu vou falar espanhol', entendeu?

Pesquisador: Sim.

Ana Cecília: Eu pensava que espanhol só era na Espanha. Que era só na Espanha que falava espanhol. E eu comecei a ver que não era só, que tinha outros países, entendeu? Pesquisador: Sei. Mas mesmo assim.

Ana Cecília: Ai, Ai mesmo assim eu continuei. Não, eu falei não: ‘eu vou falar espanhol da Espanha'. Entendeu?

\footnotetext{
${ }^{87}$ A mesma ação de localizar e identificar o questionário aplicado em dezembro de 2012 foi feita por Maria Luísa e Isabelly.
} 
Pesquisador: Entendi, então é por isso que você se identifica com o espanhol da Espanha? Ana Cecília: É, porque é uma coisa que também já vinha de antes, entendeu? Além disso, quando fala de México, de Cuba, por exemplo, agora tem esses médicos de Cuba, quando a gente pergunta pra eles se eles falam espanhol, eles não falam que falam espanhol, mas castelhano (Entrevista realizada após a finalização do semestre 2013.2).

Nesta entrevista, feita após uma análise preliminar dos dados coletados nas atividades de reflexão proporcionadas ao longo de 2013.2 (dois componentes curriculares e um curso de extensão), podemos perceber que Ana Cecília mantém uma crença que "se é espanhol, tem que ser da Espanha". Estamos diante de uma crença central, incorporada desde antes da graduação, e que mesmo depois de saber que o espanhol não é falado somente na Espanha, de ter cursado mais da metade da licenciatura em Letras-Espanhol e realizar todas as atividades proporcionadas ao longo do semestre, esta crença se mantém. Em outras palavras, temos fortes indícios de que esta crença da Ana Cecília é estável, recorrente e inflexível e é difícil provocar mudanças nela pelo fato de ser uma crença central e incorporada muito cedo e, dessa forma, pode estar interconectada com outras crenças e seria necessária a inspeção consciente e uma mudança em todo o sistema de crenças.

Neste sentido, nossa proposta parece não ter possibilitado à participante reconstruir esta crença. Pode ser que tenhamos, ao menos, possibilitado a ressignificação dela, já que antes a participante gostaria de se identificar, enquanto falante, como uma espanhola e não sabia que se falava esta língua em outros países além da Espanha. Hoje, esta crença se mantém, mas a participante tem consciência de que existem outros países em que este idioma é falado. Dessa forma, é difícil, no período de um semestre, constatar rupturas ou reconstruções. Neste sentido Barcelos (2007) argumenta que "ruptura é uma palavra muito forte" e sugere o uso da palavra ressignificação de crenças "que também não necessariamente significa 'romper' com velhas crenças, mas atribuir um novo significado a elas” (p. 114).

Outra hipótese para a manutenção desta crença é o fato de termos, no campus, uma professora efetiva que é espanhola e que atualmente é orientadora dela de TCC. Sabemos que é comum, quando vamos procurar um orientador, que busquemos por pessoas com as quais nos identificamos, respeitamos e temos como modelo de profissional competente. Dessa forma, nossa participante pode ver esta professora, que é nativa e que fala uma variante peninsular de prestígio, como um modelo de falante e de profissional, o que pode justificar o reforço desta crença.

Quanto ao argumento da participante de que há alguns países que não falam espanhol, mas castelhano, podemos perceber que ela passou pelo semestre imune às várias discussões 
que realizamos, algumas delas, inclusive, apoiadas em Valle (2005), para quem a língua espanhola é muitas coisas: "para alguns nem espanhol é: é castelhano. E o é, em cada caso, por razões bem diferentes (p. 391)" conforme discutido no item "variação e preconceito" do nosso terceiro capítulo.

Ana Cecília tem também a crença de que o espanhol da Espanha é neutro e o da América hispânica cheio de variações. Esta crença permaneceu estática durante todo o semestre, conforme podemos observar:

[Excerto 122]

Você acredita que existe variação na língua espanhola? ( x ) Sim （ ) Não. Justifique:

Porque ouvindo pessoas hispano-americanas falarem percebemos essas variações [Excerto 123] (Formulário preenchido por Ana Cecília em dezembro de 2012).

Você acredita que existe variação na língua espanhola? ( x ) Sim （ ) Não. Justifique:

Quando estudei fonética, o professor mostrou variações que ocorre de um país para outro e quando estamos assistindo, escutando músicas podemos perceber algumas variações linguísticas (Formulário preenchido por Ana Cecília em outubro de 2013).

No excerto 122, Ana Cecília revela que a variação só pode ser observada quando ouvimos hispano-americanos falando, ou seja, ela não tem consciência que a variação é inerente a qualquer país/comunidade. Esta crença é reforçada no excerto 123, em que a variação é justificada somente de um país para o outro, como se cada estado-nação estivesse composto de maneira homogênea:

[Excerto 124]

Se você nunca esteve num país que fala espanhol, qual você gostaria de visitar? Por quê? Todos, assim veria as variações linguísticas de um país para o outro (Formulário preenchido por Ana Cecília em outubro de 2013).

Tanto em dezembro de 2012, quanto em outubro de 2013, a participante respondeu que achava mais importante que um curso fosse iniciado com o espanhol da Espanha. $\mathrm{Na}$ primeira ocasião, a justificativa foi “[125] é mais fácil” e na segunda "[126] por que a princípio é apenas um país, e na hispano-américa são muitos países”. A estrutura das crenças de Ana Cecília se mostrou impermeável durante todas as atividades dedicadas ao tratamento da unidade e diversidade da língua espanhola no ensino deste idioma para brasileiros. Esta crença do espanhol peninsular como neutro, isento de variações e, logo, como melhor opção para o ensino pôde ser novamente constatada no término da investigação: 
[Excerto 127]

Pesquisador: E como fazemos ao lidar com a variação na sala de aula?

Ana Cecília: Ah! É uma coisa complicada. O melhor é manter o espanhol da Espanha, que é mais neutro (Entrevista realizada após a finalização do semestre 2013.2).

A Espanha é, para Ana Cecília, a unidade de medida, o padrão para todo o universo hispânico. Isto pode ser observado em duas ocasiões relacionadas com o filme cubano Morango e Chocolate, tanto durante a exibição, quanto no final da investigação:

[Excerto 128]

O espanhol é um pouco diferente do espanhol da Espanha. Algumas palavras eu não entendo.

Eles falam muito rápido.

Davi fala um espanhol que é mais fácil de compreender.

O Diego fala muito confuso, quase incompreensível.

[Excerto 129]

(Logs Fresa y chocolate - Ana Cecília, 07/02/2014 - Grifos nossos).

Pesquisador: Por que você ficou tão incomodada com o filme 'Fresa y chocolate'?

Ana Cecília: $\underline{O}$ espanhol falado por eles é mais diferente do que o tradicional, a voz é mais enrolada e também mais rápida (Entrevista realizada após a finalização do semestre 2013.2 - Grifos nossos).

Ana Cecília apresentou, durante todo o semestre, uma postura fechada ao outro, ao diferente, enfim, à diversidade. O excerto abaixo é mais um indício de que para esta participante, as atividades e momentos de reflexão muito pouco contribuíram para a ressignificação e reconstrução de suas crenças:

[Excerto 130]

¿Crees que FRESA y CHOCOLATE es un buen título? Contéstalo.

Creo que no. Pues la mistura de la fresa y el chocolate es buena, y la película es ruin. Es una mistura de costumbres distintas, de hablas distintas. (Atividade após a exibição do fresa y chocolate- Ana Cecília - 07/02/14)

Nossa participante se mostra completamente fechada à convivência com a diversidade, seja ela linguística ou de gênero e, no caso deste filme ainda existe uma questão delicada que é a projeção, em tela, do homossexualismo. Ana Cecília chega a se mostrar, durante a exibição e discussão do filme, como um pouco intolerante, o que vai completamente contra, inclusive, ao objetivo de Gutiérrez Alea, diretor do filme: "esta es una película contra la intolerancia. Para aprender que no siempre el que no está conmigo está contra mí” (SALVADOR, 2009, p. 190). 
Dentro da temática da unidade e diversidade, ao abordar o Espanhol dos Andes, quisemos, com a seleção do episódio "Dia Independência" 88 , trabalhar a questão dos movimentos migratórios na contemporaneidade, a exploração da mão de obra estrangeira nos grandes centros urbanos, a prática da alteridade, a questão da interculturalidade e a da importância de políticas públicas para promoção da educação bilíngue no contexto da integração latino-americana.

Como atividade prévia, fizemos uma sondagem a respeito do que os participantes sabiam a respeito da Bolívia, dos bolivianos e da presença deles no Brasil:

[Excerto 131]

O que você sabe a respeito da Bolívia e dos bolivianos? Nada.

Qual(is) língua(s) são faladas neste país? Espanhol.

Você já assistiu algum filme boliviano? Não.

Você sabe algo a respeito dos bolivianos no Brasil? Não.

(Sondagem aplicada uma semana antes de iniciarmos a unidade temática Bolívia, Ana Cecília, 07/02/2014).

Com isso, constatamos a total invisibilidade, por parte de Ana Cecília e da grande maioria dos nossos professores em formação, dos bolivianos no universo hispânico. Dessa forma, os momentos que antecederam a projeção audiovisual foram dedicados à história desse povo, à apresentação de alguns traços culturais, aos movimentos migratórios, à concentração de bolivianos em São Paulo, à Praça Kantuta como preservação da memória, da cultura e da construção de um “entre-lugar" ${ }^{89 "}$ em pleno coração de São Paulo, comentamos a reportagem publicada a respeito da primeira escola pública bilíngue português-espanhol inaugurada no Rio de Janeiro e algumas notícias relacionadas à exploração da mão de obra nas indústrias de confecção em São Paulo.

$\mathrm{Na}$ tela, foram representados os bolivianos vivendo em São Paulo. Checho, o protagonista da história, é uma criança que transita entre a língua espanhola (em casa) e o português (na escola). A questão da língua como identidade perpassou nossas discussões e Ana Cecília demonstrou uma boa percepção neste sentido:

[Excerto 132]

Na casa todos falam espanhol, com exceção de Checho, que fala português. Podemos dizer que ele é a ponte entre a cultura/língua da Bolívia e do Brasil? Por quê?

Não, porque ele nega sua cultura e, ao mesmo tempo, é rejeitado por alguns colegas da escola, no Brasil. Diante disso, para ele tanto faz falar Brasileiro como Boliviano (Atividade filme após a exibição do episódio Dia da Independência, da série Destino São Paulo - Ana Cecília).

\footnotetext{
${ }^{88}$ Da Série “Destino: São Paulo” (GABASSI, Alex [Dir.] HBO Brasil, 2012).

${ }^{89}$ Nos termos de Bhabha (1998).
} 
Ana Cecília percebeu o conflito identitário pelo qual passava nosso protagonista, desterritorializado, vivendo um conflito entre duas línguas e culturas sem se sentir aceito e seguro, de forma a ser respeitado em sua individualidade, como pertencente a nenhuma delas, já que o ambiente familiar (em espanhol) era hostil e o escolar (em português) também.

A partir do fragmento do filme:

À noite, quando Checho tenta abrir a caixa para procurar o passaporte dos funcionários que estão sendo explorados pelo seu padrasto ele é repreendido e obrigado a repetir que nunca mais faria aquilo:

Padrasto: Nunca más voy a hacer eso, Repetí.

Checho: Nunca mais vou fazer isso.

Padrasto: En español, carajo!

(Fragmento do episódio Dia da Independência).

Pedimos que Ana Cecília comentasse a relação entre língua e identidade apresentada no fragmento citado. Tivemos como resposta:

[Excerto 133]

Checho, falando português para o seu padrasto está traindo ele e falando português está fugindo de sua cultura e de sua língua (Atividade filme após a exibição do episódio Dia da Independência, da série Destino São Paulo - Ana Cecília)

A mesma postura positiva de identificação e compreensão de um conflito identitário pode ser observada na resposta de Ana Cecília à reflexão proposta: “A mãe de Checho está preparando as roupas para que eles possam ir a uma festa típica. Qual é a reação dele em relação a esta festa e a ideia da professora em promover algo a respeito da Bolívia na escola? A postura dele é de valorização ou negação da cultura de sua origem? Justifique”:

\section{[Excerto 134]}

Reação de negação. Pois quando sua mãe está preparando as roupas ele acha elas feias e não quer usar. Quando sua professora propõe uma festa típica ele rejeita sua cultura (Atividade filme após a exibição do episódio Dia da Independência, da série Destino São Paulo - Ana Cecília).

Assim como as crenças, o ser humano é contraditório por natureza. Ana Cecília, que diante deste produto audiovisual se demonstrou, inicialmente, sensibilizada e aberta à questão da língua como identidade, se apresentou isenta de alteridade ao longo da oportunidade de reflexão. Havia uma pergunta que explorava um trecho em que Checho, após sofrer muito bullying, agressão física e exploração financeira na escola pelo fato de ser estrangeiro, se rebelou contra seu agressor e foi enviado para a direção da escola. O diretor ignorou a professora da sala que sabia, de fato, de tudo que vinha ocorrendo e inverteu a situação de forma que o garoto foi considerado como agressor e não como agredido. A mãe do garoto é 
convocada a comparecer na escola e, a partir disso, o diretor trava uma conversa cheia de preconceito e agressão simbólica:

Diretor: E então, a senhora fala português?

Estela: Um poco.

Diretor: Dona Ester a senhora tem marido?

Estela: Sí.

Diretor: E, porque que ele não veio?

Estela: Ele trabalha muito.

Diretor: A senhora me entende? Hablas portugués?

$[\ldots]$

Diretor: Dona Ester, a senhora não está me entendendo muito bem... A senhora não está falando português, Se eu for para o país da senhora eu vou ter que falar a mesma língua da senhora. Se a senhora está no meu país a senhora tem que falar a mesma língua que eu... Porque senão eu não entendo o que a senhora fala (Fragmento do episódio Dia da Independência).

Quando questionada: "Como ficam as relações de poder na e pela linguagem durante esta conversa? Era, de fato, necessário falar português, como enfatizou o diretor?”, Ana Cecília responde:

[Excerto 135]

Na conversa com o diretor era de fato necessário falar português como enfatizou o diretor sim. Pois ela está no Brasil, morando, seu filho estuda com brasileiros então a conversa deveria ser em português. Ele não deveria ter conversado com o tom de voz que conversou, mas era para ser em português. Quando estamos na Bolívia, como enfatizou o diretor, temos que falar em espanhol (Atividade filme após a exibição do episódio Dia da Independência, da série Destino São Paulo - Ana Cecília - 28/02/14).

Esta postura de Ana Cecília, para um futuro professor de língua estrangeira, do qual se espera a postura de um mediador intercultural atento às discursividades que envolvem a língua espanhola enquanto idioma multidimensional e intercultural; é forte, enfática e totalmente isenta de alteridade. Sabemos que a mãe boliviana está no Brasil, mas temos consciência das relações de poder expressadas na e pela linguagem e da situação de desfavorecimento político-social à qual esta mulher está submetida em nosso território.

Em entrevista, questionamos Ana Cecília a respeito da postura do diretor, e ela novamente argumentou:

[Excerto 136]

A postura foi grosseira para um diretor, mas em relação a ele querer que Ester falasse em português para mim foi correta (Entrevista realizada após a finalização do semestre 2013.2).

Diante do discurso de Ana Cecília, nos questionamos: e a alteridade, tão trabalhada nos momentos de reflexão? E o espírito da integração latino-americana tão debatido ao logo 
das atividades, de considerar o linguístico como fundamental já que devemos buscar o reconhecimento da América Latina como uma construção cultural e não somente geográfica? O cinema cumpriu para esta participante um papel relevante de imersão na iniciação da prática da cultura audiovisual e acreditamos que possibilitou plantar algumas sementes que germinarão, tomara, no futuro.

Porém, no que concerne às expectativas da pesquisa, tivemos indícios de que o sistema de crenças de Ana Cecília passou impermeável pela maior parte dos momentos de reflexão propiciados ao longo do semestre e o cinema muito pouco possibilitou a ressignificação e reconstrução das crenças desta participante.

Acreditamos que isto está atrelado aos fatores contextuais da participante de forma ampla: criada num entorno rural, sem acesso à cultura audiovisual, a computadores e à internet. Aluna sempre de escola pública, algumas vezes em salas multiseriadas da zona rural, provavelmente, Ana Cecília nunca teve oportunidades de letramento audiovisual.

Conforme relata em sua autobiografia e pudemos apurar em conversas informais, Ana Cecília nunca se identificou com o estudo de línguas estrangeiras, ingressou no curso de Letras-Espanhol por falta de opção e, mesmo que agora, depois de transcorrido metade do curso, ela se identifique e se empenhe, existe toda uma bagagem de fatores contextuais que influenciam a sua cognição.

\subsection{Isabelly}

Isabelly tem 21 anos, é brasileira, solteira, tem sete irmãos, mora na zona urbana de uma cidade próxima à Monteiro e viaja todos os dias para estudar. Ela trabalha e estuda, é funcionária pública municipal na área da saúde. A escolaridade do pai é o ensino fundamental completo, ela cursou o ensino fundamental e médio todo em escola pública, frequentou cursinho pré-vestibular durante um semestre e, assim como as outras duas participantes, nunca viajou para o exterior.

Ela sempre gostou de estudar inglês, mas este contato ficou limitado à educação básica. Ela possui computador, mas não tem conexão com a internet em casa, nunca foi ao cinema, teatro, museu e não tem o hábito de baixar filmes da internet, mas relata que já tentou e não conseguiu e que tem o hábito de assistir filmes quase toda semana. Apresentamos a autobiografia de Isabelly, que será comentada a seguir. 
Cuando el profesor me dijo que deberíamos escribir una biografía, nuestra primera actitud fue de recusa total. ¡Dios mío!, pensé, ¿por qué? Mi cara estaba como la de Monalisa, sin reacción, sin creer en aquello, ¿en realidad, teníamos que hacer esa tarea? Hablar de nosotros mismos, sobre lo que está mucho más allá de las cuatro paredes de la universidad, de nuestra vida, nuestras experiencias como aprendices de español, no es una tarea sencilla, ni tampoco fácil. Creo que sean tales experiencias que nos hacen lo que somos hoy, y lo que vamos a ser un día. Con Dios guiándonos y nuestra familia apoyándonos todo es posible.

Entonces vamos a hablar de mí y de mi recorrido como aprendiz. La verdad es que el español surgió en mi vida como una bella sorpresa, que se me presentó, yo tan inmatura ni pensaba que me encantaría tanto esa lengua y sus hablantes en los más variados rincones del mundo.

Mi primera experiencia con una lengua extranjera, creo que como la mayoría de nosotros, se dio en la escuela con las clases de inglés, los famosos diálogos, el verbo to be y los repeat after me, marcaron toda mi experiencia con el inglés. Ya el español me pareció más accesible, y nuevamente como la mayoría de nosotros creía que era más fácil, la pregunta que me hago hoy es: ¿fácil para quién? Pues para mí no creo que lo sea. Recuerdo que, cantando las músicas en español de la banda Rebelde, mi primera experiencia real con el español se dio por la Tele. ¡Qué horror!, pensé, pero experiencia válida, la música es un importante medio para conocer una lengua.

Otro hecho curioso fue que, cuando estaba a punto de hacer la selectividad para ingreso en la universidad, el inglés siempre fue mi prioridad cuando pensaba en aprender una lengua extranjera. Me encontraba delante de una gran duda. ¿Qué hacer? Mis opciones no eran grandes pero existían; por fin, en el último momento, el español como un imán me magnetizó. Y decidí por letras-español, ¿qué raro no? Ni siquiera pasó por mi cabeza la docencia, solamente la lengua, aprender el español, pero tampoco enseñarlo.

Tras el miedo de descubrir que también enseñaría, fui a los pocos encantándome por el español, y no digo solamente por la lengua, sino por todo lo que se relaciona con ella. No podía escuchar una música que quería aprenderla, una película que quería que el audio fuera en español, y qué desilusión cuando no era, ver las expresiones, las ropas, el modo de andar, sus relaciones afectivas, hablar por Internet con nativos, todo era nuevo, desconocido. Leer, entonces, ¡me fascinaba! Qué felicidad cuando al leer entendí que el $d o s$ en portugués es diferente del dos en español, que el último era un numeral, cosa tan simple pero que me marcó. Y las literaturas, española e hispanoamericana, qué felicidad leerlas y conocer mucho de sus entrelíneas, un sueño realizado, conocer un poco sobre las literaturas extranjeras. Dicen que, cuando leemos un libro, viajamos sin salir del lugar. Qué mágicos viajes hice y aún hago. De esa manera conocí a personas, unas que pasaron, otras que siguen en el presente y otras que sé, permanecerán en el futuro. Personas desconocidas, que así como la lengua, a los pocos, las fui conociendo, se volvieron amigas, sufrí con sus sufrimientos, me preocupé cuando algo salía errado y con la posibilidad de distanciarnos en la caminada, aprendimos a ser más humanos, pero también más realistas, la vida se volvió llena de obligaciones y de momentos inolvidables.

Entendí que la lengua era mucho más que descodificación de palabras. Delante de todo eso siempre me encantó recibir los inputs de los hablantes, pero mi mayor dificultad permaneció en hablar: el miedo de la pronunciación, de no ser comprendida me paralizó muchas veces y aún me paraliza. Las clases de pasantía me atormentaban, pero aprendí a enfrentar mis miedos, nuevas experiencias, nuevos comienzos. ¡Sí! Impartí clases y lo que más me sorprendió es que no me salió del todo horrible, descubrí las dos caras de una misma moneda, el placer de transmitir mis conocimientos, de relacionarme con los alumnos. Y la total falta de interés, de expectativas de muchos, eso sin duda me entristeció. 
Por fin, quiero dejar algunas palabras sobre el futuro. No sé cuál será pero sé que voy a luchar y dedicarme en hacer lo mejor posible. No sé si seré una profesora, pero todavía no empecé a hacer mi trabajo de conclusión de curso. Sé que cuando sembramos, un día viene la cosecha, pues creo que mis frutos serán buenos. Y como dice Alejo Carpentier "Todo futuro es fabuloso", ¿por qué el mío no lo será?, estoy trabajando para ello, y sé que no desistiré de intentarlo (Autobiografia de Isabelly, elaborada no final do semestre letivo).

Isabelly destaca o papel do que foi vivido na sua constituição atual e na projeção do que será no futuro. A primeira experiência dela com a língua estrangeira, assim como a da maioria das pessoas, deu-se de maneira frustrante com o inglês: "los famosos diálogos, el verbo to be y los repeat after me”.

A primeira experiência dela com o espanhol foi mediada pelo audiovisual, ela relata a importância da TV como reveladora das músicas dos Rebeldes. Apesar de ter tido sempre o inglês como prioridade no momento em que fosse aprender uma língua estrangeira, diante das poucas opções oferecidas pela região, ela foi atraída, no último momento, pelo espanhol, como se fosse um imã. Ela acreditava que estudar espanhol, pela semelhança que o idioma tem com o português, seria fácil. Não demorou muito para perceber que por trás da transparência existe a opacidade: "la pregunta que me hago hoy es: ¿fácil para quién? Pues para mí no creo que lo sea".

A autobiografia foi escrita no final do semestre 2013.2 e já podemos perceber no vocabulário da nossa participante alguns dos termos trabalhados durante nossas atividades “entendí que la lengua era mucho más que descodificación de palabras. Delante de todo eso siempre me encantó recibir los inputs de los hablantes”.

Isabelly relata a dificuldade na aquisição da habilidade de expressão oral: "mi mayor dificultad permaneció en hablar: el miedo de la pronunciación, de no ser comprendida me paralizó muchas veces y aún me paraliza”. Este tema recebeu a atenção de vários estudiosos, conforme já comentamos nesta tese. Revuz (1998) destaca a dimensão de socialização da língua e, como consequência, sua complexidade ao demandar uma prática de expressão, mais ou menos criativa, que solicita do sujeito seu modo de relacionar-se consigo mesmo, com os outros e com o mundo e uma prática corporal que põe em jogo todo o aparelho fonador.

Nossa participante chegou ao curso de Letras-espanhol via encantamento com a língua, de imediato, nem passou pela cabeça dela ser professora. Porém, ao longo do curso, ela tem, aos poucos construído sua identidade "eu professor", os minicursos e oficinas ministrados ao longo dos componentes curriculares de estágio atormentavam Isabelly mas, 
aos poucos, ela foi aprendendo a enfrentar seus medos e a aproveitar "nuevas experiencias, nuevos comienzos". Ela relata indícios da constituição profissional como professora: "impartí clases y lo que más me sorprendió es que no me salió del todo horrible, descubrí las dos caras de una misma moneda, el placer de transmitir mis conocimientos, de relacionarme con los alumnos. Y la total falta de interés, de expectativas de muchos, eso sin duda me entristeció".

Nossa participante relata uma postura positiva, de disposição a novas experiências e novos começos, bem como a abertura em relação ao contato com os outros e as oportunidades que a vida oferece: "sé que cuando sembramos, un día viene la cosecha, pues creo que mis frutos serán buenos".

\section{Experiências relacionadas ao processo de aquisição/aprendizagem do E-LE}

Quando questionada se ela pôde extrair de "O Terminal" alguma "lição" que pode contribuir para a forma como se aprende E-LE, Isabelly declara saber que se está diante de um processo complexo e lento, de construção e reconstrução contínua do processo de interlíngua, logo, uma crença favorável ao processo de ensinar e aprender línguas já que a participante tem consciência de que não podemos esperar resultados mágicos e rápidos:

[Excerto 137]

Sim. Que uma LE não se aprende do dia para a noite, que sempre vai existir interferências da língua materna na construção da competência na língua estrangeira (Atividade feita após a exibição do filme $\mathrm{O}$ terminal - Isabelly - 06/12/13).

Isabelly tem consciência da importância da prática da alteridade e consegue perceber as consequências, no comportamento de uma personagem do filme Um conto chinês, da falta da prática dessa alteridade:

[Excerto 138]

[Roberto tem] atitude negativa frente à cultura chinesa e ao povo chinês. Sempre os compara. Ele não quer compreender/entender, só quer ser compreendido. Não procura saber o que o chinês quer dizer ( Log Um conto chinês - Isabelly 08/11/12).

Diversas conversas informais ao longo do semestre nos permitem constatar que nossa participante tem consciência das consequências da falta da alteridade para o processo de aquisição de línguas. Quando questionada a respeito do que "Um conto chinês", "Albergue Espanhol" e "Espanglês" têm em comum em relação ao processo de aquisição/aprendizagem 
de uma língua estrangeira ela destaca a necessidade de estar disposto à interação com os outros:

[Excerto 139]

O que os três filmes tem em comum é a necessidade de achegar-se, aproximar-se da língua estrangeira quando se deseja aprendê-la, em seus múltiplos aspectos (Atividade feita após a exibição do filme Espanglês, Isabelly, 22/11/2013).

Foi possível explorar em sala de aula, com a mediação dos filmes, a conscientização para os diversos estilos, crenças, hábitos, estratégias e atitudes que envolvem o processo de ensinar e aprender línguas. Pedimos a Isabelly que relatasse o que os três filmes "Um conto chinês", "Albergue Espanhol" e "Espanglês" tinham de diferente em relação à representação do processo de aquisição/aprendizagem de uma língua estrangeira. Ela destacou:

[Excerto 140]

A diferença está na maneira que cada um percebe a língua para si. Uns abertamente, outros receosos, uns por necessidade, outros por prazer. Cada pessoa que se detém a adquirir ou aprender uma nova língua reage de uma determinada maneira, de acordo com seus próprios valores e ideais (Atividade feita após a exibição do filme Espanglês, Isabelly, 22/11/2013).

Após a exibição de "O terminal", o quarto filme a tocar na temática da aquisição/aprendizagem de línguas, perguntamos para Isabelly se as estratégias, hábitos e atitudes dela em relação à aquisição/aprendizagem da língua espanhola foram, de alguma forma, alteradas a partir das experiências com os quatro filmes assistidos até aquele momento (Um conto chinês, Espanglês, Albergue Espanhol, O terminal). A resposta da nossa participante continuou dando ênfase na consciência dos diferentes hábitos e estratégias envolvidos no processo, que podem mudar de pessoa para pessoa e da importância da prática da interculturalidade:

[Excerto 141]

Sim. Creio que analizando os filmes pude perceber que há diferentes formas e atitudes que apresentamos frente a uma nova língua. $\mathrm{E}$ que devemos ter cuidado para não termos atitudes etnocêntricas ou de relativismo cultural (Atividade feita após a exibição do filme O terminal - Isabelly - 06/12/13).

Quando questionada se os filmes mudaram de alguma forma a visão a respeito de como se aprende uma língua, Isabelly destaca o potencial da sétima arte em apresentar diferentes formas de se adquirir/aprender uma língua:

[Excerto 142]

Sim. Por que podemos ter uma noção de como se adquire uma língua estrangeira. Não é tarefa fácil, pois lidar com novos modos de vida e de expressão causa um pouco de confusão (Atividade feita após a exibição do filme Espanglês, Isabelly, 22/11/2013). 
Após a exibição dos filmes "Um conto chinês", "Albergue Espanhol" e "Espanglês", perguntamos à Isabelly se ela, enquanto aprendiz de língua estrangeira, tinha se identificado com algum dos personagens mostrados nos três filmes exibidos até o momento. Ela argumentou ter se identificado com Xavier, protagonista do filme "Albergue espanhol", e justificou:

[Excerto 143]

Sim, Xavier. Pelo desejo dele de sair do seu local de conforto e buscar novos horizontes, novas possibilidades (Atividade feita após a exibição do filme Espanglês, Isabelly, 22/11/2013).

Durante uma aula, perguntamos a Isabelly quais horizontes ela tem buscado, a partir do exemplo de Xavier, para fortalecer sua relação com o E-LE:

[Excerto 144]

Eu acho assim, eu tô procurando aprender ler, sempre procuro ler, assistir, ouvir, assistir com legenda, sem legenda ou não ficar olhando na legenda, me esforçar ao máximo para que eu possa me acostumar com a sonoridade, com o jeito de falar, né?

Na ocasião, ela deu ênfase às tentativas de entrar em contato com materiais, insumos autênticos. Retomamos a temática na entrevista final:

[Excerto 145]

Pesquisador: Você se identificou o com Xavier, do filme Albergue Espanhol, certo? Isabelly: Sim, foi o personagem que eu mais gostei.

Pesquisador: Ok. E para a Isabelly, em relação à língua espanhola, o que significa sair da zona de conforto e buscar novos horizontes hoje?

Isabelly: Bom, muita coisa.

Pesquisador: Quais coisas?

Isabelly: Eu tomei consciência de como se aprende a língua. Que não existe a melhor maneira de aprender, mas vários caminhos possíveis.

Pesquisador: E você, encontrou o seu caminho?

Isabelly: Acho que sim, não existe um só caminho e hoje eu sei que posso mudar, experimentar novos caminhos.

Pesquisador: Até porque já dizia Antonio Machado, que quem caminha não tem caminho, faz caminho ao andar, né?

Isabelly: [risos] O mais importante pra mim foi tomar conhecimento de que é possível aprender sem morar no país daquela língua.

Pesquisador: Por quê?

Isabelly: Antes eu achava que a gente só aprendia morando no lugar. Já com os filmes eu vi que o segredo não é morar no lugar, que é preciso querer aprender, se dedicar, se empenhar.

Pesquisador: Você pode me dar um exemplo?

Isabelly: Xavier e Ana Sofie, em Barcelona, eles chegaram juntos, ele aprendeu a língua, ela não.

Pesquisador: e quais os novos horizontes que você tem buscado?

Isabelly: Tenho me soltado mais, me permitido falar mais, mesmo que isto signifique errar mais, risos...

Pesquisador: mas o erro faz parte! Só erra quem faz, quem tenta, tenta e consegue. 
Isabelly: Pronto, e tenho usado mais a internet, vídeos, músicas, propagandas e até filmes... (Entrevista realizada no final do semestre).

Isabelly nos revela que o cinema possibilitou a ela a desconstrução de uma crença prejudicial ao processo de ensino-aprendizagem, principalmente para alunos afastados geograficamente de grandes centros urbanos e com poucos recursos financeiros para deslocamentos geográficos.

Ela relata ter tomado consciência de que qualquer pessoa, desde que esteja disposta e se dedique a isso, pode adquirir/aprender uma língua estrangeira sem deslocamentos geográficos para ir viver no território em que a língua é falada. O cinema foi mediador da construção desta crença na medida em que apresentou vários personagens vivendo em contexto de imersão e nem todos eles adquiriram/aprenderam a língua-alvo pelo simples fato de estarem imersos em contextos reais de uso daquela língua.

Outro ponto tocado pela nossa participante foi a questão da oralidade, considerada por ela como a habilidade mais difícil de ser adquirida. Ela relata que, a partir do cinema, tem se permitido se soltar mais ao falar. Este tema foi recorrente em vários momentos, a autobiografia dela ilustra isso: "pero mi mayor dificultad permaneció en hablar: el miedo de la pronunciación, de no ser comprendida me paralizó muchas veces y aún me paraliza”.

[Excerto 146]

Pesquisador: Você disse que falar era a sua principal dificuldade, o cinema contribuiu em algo?

Isabelly: Sim, me ajudou a perceber que a fala é natural, é uma necessidade do ser humano para sobrevivência, vai chegar um momento que você vai se expressar e vai sair. E eu tenho tentado ficar mais a vontade para falar (Entrevista realizada no final do semestre).

O excerto apresentado nos relata o discurso da nossa participante com a tomada de consciência da fala como uma característica inerente ao ser humano e que, portanto, tem permitido a ela tomar o turno do discurso com mais tranquilidade na língua estrangeira.

\section{O cinema como mediador na constituição da identidade docente}

Isabelly relatou ter chegado ao curso de Letras-Espanhol ao acaso, foi atraída, magnetizada pelo espanhol, mas que nem tinha passado pela sua cabeça a docência. Podemos observar que, aos poucos, nossa participante vai constituindo sua identidade docente e o cinema tem mediado esse processo. 
Em uma sessão reflexiva a respeito do conteúdo preparado para o minicurso em que ministraria em parceira com uma colega da sala no componente curricular estágio supervisionado, Isabelly nos apresenta indícios de ter a crença de que só se aprende no engajamento em atividades socialmente relevantes para o indivíduo e não por meio da repetição de regras.

[Excerto 147]

Por que a base do nosso minicurso de espanhol tem a principal importância de proporcionar um aprendizado de forma mais atrativa e lúdica. Através de filmes, músicas, diálogos, entre outros temas. Abrange em sua base o nosso meio social, relacionando com a vida de cada participante e não seguindo um ensino baseado somente em livros didáticos ou na gramática. $\mathrm{O}$ aluno parece estar tão cansado de ver sempre regras, que não se interessa mais por determinados assuntos, assim nosso intuito com este novo conhecimento didático é estimular a curiosidade do aluno para o aprendizado de uma nova língua, no caso o espanhol (sessão de reflexão crítica a respeito do plano de curso do Estágio - Isabelly e Aline, 12/11/12)

Ficamos curiosos em saber se esta crença se embasava em conceitos cotidianos ou em conceitos científicos advindos da abordagem sociocultural, que prevê a construção do conhecimento por meio do engajamento em atividades sociais relevantes. Diante dessa dúvida, tocamos no assunto durante a entrevista final:

[Excerto 148]

Pesquisador: Você fala muito, nos seus planos de aula, que os alunos só aprendem no engajamento em atividades relevantes e não por meio da repetição de regras. Onde você aprendeu isso, de onde vem esta concepção sua?

Isabelly: Uma parte é pela análise que eu fiz da escola quando eu estudava, que muitas vezes o professor ensinava aquilo que ele achava importante e não aquilo que para os alunos era importante, e eu fui observando que isso às vezes não é bom, a gente precisa ensinar levando em conta o que o aluno precisa aprender e o que ele está disposto a aprender também (Entrevista realizada no final do semestre).

Conforme pudemos observar em sua autobiografia, as oportunidades de prática de ensino propiciadas ao longo do curso de Letras atormentavam Isabelly mas, aos poucos, ela foi aprendendo a enfrentar seus medos e a aproveitar as novas experiências de forma a até ser surpreendida em algumas delas. No componente curricular estágio supervisionado Isabelly e uma amiga ficaram responsáveis por preparar e aplicar um minicurso para adolescentes da comunidade em que estão envolvidas. O plano preparado por elas apresentava como insumos músicas, filmes, propagandas e tinha como objetivos:

[Excerto 149]

Este curso tem como objetivo se desviar das aulas expositivas e lineares a que muitos professores se detêm no momento de ensinar uma língua estrangeira. Nossa proposta se foca num ensino lúdico e diferenciado. Percebemos que o ensino de uma LE não deve 
minimizar a língua apenas ao caráter comunicativo ou gramatical, mas também buscar outros meios de ensino/aprendizagem que fomentem o interesse do aluno para a língua espanhola em suas múltiplas especificidades. Buscamos então a socialização entre o ensino de línguas e o conhecimento de mundo que o aluno possui. (Plano de curso "Aprendendo espanhol de forma lúdica e descontraída". Isabelly e Aline, novembro de 2013).

Antes da execução do minicurso, fizemos algumas sessões de reflexão a partir das inquietações apresentadas por Silva (2004) em torno da temática identidade e currículo. Neste sentido, ao serem questionadas a respeito de quais interesses guiaram a seleção deste conhecimento apresentado no plano de curso em particular, Isabelly e a parceira da proposta responderam:

[Excerto 150]

Foi a oportunidade de ensinar com uma metodologia diferente, sem o uso apenas das gramáticas, queremos usar conteúdos que os alunos desenvolvam as quatro habilidades linguísticas. [...] Esperamos promover um aprendizado que sugere uma atitude crítica e reflexiva dos discentes. [...] Queremos observar se, com nossa metodologia, estamos realmente indo pelo caminho certo (sessão de reflexão crítica a respeito do plano de curso do Estágio - Isabelly e Aline, 12/11/12)

Após a primeira semana de implementação do minicurso, Isabelly relatou que ficou emocionada com o comportamento de um aluno diante de uma atividade com o filme " $\mathrm{O}$ estudante" ${ }^{90}$. Isabelly, que nunca havia pensado em ministrar aulas, relatou que não esperava que iria se apaixonar tanto pela docência e que passaria por uma situação como aquela em que ficou emocionada com o feedback de um aluno, nas palavras dela, que era muito "traquina", dava muito trabalho e que no final da aula ele falou: "professora meu olho quase encheu de lágrimas no final do filme".

Isabelly já havia sido nossa aluna em semestres anteriores, nos componentes curriculares Língua Espanhola IV e Língua Espanhola V, em ocasiões nas quais já tínhamos lançado mão do cinema como recurso didático. Diversos pesquisadores da Linguística Aplicada destacam que os alunos, muitas vezes, na hora de atuar como professores ligam suas experiências diretamente àquilo que tiveram como modelo enquanto aprendizes. Nesta mesma linha, Borg (209, p. 3) argumenta que as cognições dos professores podem ser fortemente

\footnotetext{
${ }^{90}$ Um filme mexicano de 2009, dirigido por Roberto Girault Facha que retrata a aventura de Chano, um homem de 70 anos de idade que ingressa em uma universidade para estudar Literatura. Lá, se depara com o mundo dos jovens, de costumes e tradições muito diferentes das suas. Tomando Dom Quixote como exemplo, Chano rompe a barreira entre gerações e faz novos amigos. Ao longo da narrativa a esposa de Chano morre e são seus jovens amigos que o ajudam a superar esta perda. A grande contribuição deste filme é, para nós, a compreensão de que nesta vida, independente da idade, seremos todos eternamente professores e estudantes, sempre aptos a ensinar e aprender.
} 
influenciadas por suas experiências como aprendizes. Isso pode ser comprovado no caso desta participante, que enquanto aprendiz de línguas teve, conosco, diversas oportunidades de contato com o cinema como ferramenta didática e reproduziu esta experiência em sua primeira aula de prática de ensino.

[Excerto 151]

Pesquisador: tanto é que no minicurso do estágio supervisionado você trabalhou com filmes, né?

Isabelly: Por que os filmes estavam me perseguindo, [risos...]

Pesquisador: E como você avalia a nossa experiência com o cinema ao longo do semestre?

Isabelly: Eu achei positiva, é interessante trabalhar com a arte na sala de aula, porque ela te mostra muitas facetas, não é só língua nem só estrutura, mas muitas facetas, e uma não supera a outra, complementa (Entrevista realizada no final do semestre).

Ainda em relação à sua constituição docente, Isabelly nos apresenta indícios de uma formação rumo à interculturalidade. Ao final da exibição do Espanglês, nossa participante ao ser questionada a respeito do que mais gostou no filme - relatou ter se identificado com a personagem Cristina, e justificou:

\section{[Excerto 152]}

Gostei de Cristina, pois ela era multicultural e tanto se expressava como se relacionava de formar a ser entendida pelas duas partes [a culta mexicana e norte-americana] (Atividade feita após a exibição do filme Espanglês, Isabelly, 22/11/2013).

Retomamos este tema na entrevista final e pudemos perceber o despertar da consciência de Isabelly para o papel do professor como um mediador intercultural entre a cultura caririzeira ${ }^{91}$ e o universo hispânico:

\section{[Excerto 153]}

Pesquisador: Quando você assistiu Espanglês você comentou, na atividade, que se identificou com Cristina, pois ela era multicultural e transitava por duas culturas, certo? Isabelly: Sim, eu gostei muito.

Pesquisador: E a Isabelly, como tem transitado pela cultura caririzeira e pelo universo hispânico?

Isabelly: Ai é o problema, né? Por que a cultura caririzeira eu estou em contato no dia a dia, sempre, mas o universo hispânico é mais diferente, principalmente pela distância. O contato, e também gera um certo medo, esse contato com o desconhecido.

Pesquisador: E você como professora, você acha que pode fazer esse papel que a Cristina fazia no filme?

Isabelly: Eu, posso tentar, só não posso garantir... estou estudando e me dedicando pra isso, como professora, no cariri, posso trazer o mundo hispânico ao cariri e possibilitar a mudança de ver o mundo dos meus alunos. E sei que o cinema também pode me ajudar a apresentar esses mundos distantes e desconhecidos.

91 Relativo aos modos de vida, às práticas culturais realizadas cotidianamente no cariri ocidental paraibano, contexto no qual estamos inseridos. 
O discurso de nossa participante nos dá indícios da percepção dela para a possibilidade de integração, via ensino e com o apoio do cinema, de universos ricos em arte e cultura, que podem se fundir, se (re)significar, constituindo imaginários que possibilitem expandir a mente, ampliando a consciência de mundo.

Durante a exibição do filme argentino "Um conto chinês", ao perceber que era apresentada em tela a personagem Mari, que fazia o papel de uma espécie de mediadora intercultural entre Roberto (argentino) e Jun (chinês), Isabelly registrou um log:

[Excerto 154]

Mari acredita que se pode comunicar através de fotos (arte). (Log Um conto chinês Isabelly 08/11/12).

O momento em que Mari mostrava fotos ao chinês, na tentativa de superar as barreiras linguísticas e buscar promover a interação com o estrangeiro e integrá-lo ao grupo foi percebido por Isabelly como uma tentativa de utilizar a arte como meio de integração entre culturas e universos distintos.

Durante a entrevista final, questionamos se ela já havia pensava nisso antes, que era possível ensinar e se comunicar por meio da arte ou foi algo que surgiu durante as atividades propiciadas ao longo do semestre 2013.2. Isabelly respondeu:

[Excerto 155]

Isabelly: Foi, assim, ao longo do semestre abriu mais o caminho, que a língua não é só estrutura, eu, a língua vai muito mais além, né? que a língua não é só regra, e podemos explorar justamente, por ser o poder mediador da arte, que ela pode ser entendida, sentida por todos, independente da cultura, da língua, da região e da religião...

Pesquisador: Você já tinha pensado antes que a arte podia mediar?

Isabelly: Não. No começo eu estava muito perdida, eu sempre fui muito perdida, eu entrei para estudar espanhol pelo espanhol, pela língua e depois, aos poucos, eu fui descobrindo que existem povos, universos por trás das línguas, né?

As oportunidades de reflexão compartilhada possibilitaram à nossa participante construir uma crença positiva a respeito do papel da arte como uma linguagem universal que pode transpor barreiras linguísticas e, portanto, insumo propício ao ensino-aprendizagem de línguas.

Exemplo disso foi que a participante nos procurou ao longo do semestre propondo que a orientássemos no desenvolvimento do projeto que dará origem à monografia que será apresentada como trabalho de conclusão de curso com foco nas possíveis contribuições das artes ao ensino de línguas. 
No final do semestre Isabelly já tinha finalizado a elaboração do projeto de TCC “As artes e o ensino de línguas: uma via de mão dupla" e agora ela faz as primeiras leituras para a constituição de um embasamento teórico que sustentará reflexões a respeito do "estudo das possibilidades de relação existentes entre as artes (cinema, literatura, teatro, dança, música, pintura e escultura) e o ensino de línguas estrangeiras, com base na linguística aplicada, com vistas ao desenvolvimento do aprendiz numa perspectiva sociocultural" (trecho texto final do projeto de Isabelly).

\section{A unidade e a diversidade no universo hispânico}

Utilizando como instrumento um formulário, perguntamos para Isabelly, em dezembro de 2012 e, novamente, em outubro de 2013 se ela achava mais importante que um curso fosse iniciado pelo "espanhol da Espanha” ou pelo "espanhol da América”. Nas duas ocasiões ela não marcou nenhuma das duas opções e apresentou justificativas plausíveis:

[Excerto 156]

Acredito que nenhum dos dois, creio que se deve iniciar apenas com "espanhol", mas mostrando que existem variações em determinados lugares (Isabelly - Sondagem efetuada em Dez/2012).

\section{[Excerto 157]}

Nenhum dos dois, o que o professor for mais seguro ao ensinar. Apesar de eu acreditar que exista apenas o espanhol e suas variedades (Isabelly - Sondagem no início do componente curricular L.A., Out/2013).

Diante das justificativas da nossa participante, principalmente do trecho em que ela cita acreditar "que exista apenas o espanhol e suas variedades" ficamos nos questionando se isso seria um indício de que ela tem uma crença positiva de que estamos diante de uma língua una e múltipla ao mesmo tempo e que acredita serem os rótulos como "espanhol da Espanha" e "espanhol da América", por exemplo, arbitrários. Diante dessas inquietações, abordamos o tema novamente na entrevista final:

[Excerto 158]

Pesquisador: O que você quer dizer com isso? Você acha que não é certo falar "espanhol da Espanha", "Espanhol do México", que seria, na verdade, tudo "espanhol"?

Isabelly: Sim, eu acho que o professor não deve se limitar a dizer que isso é daqui, que aquilo é de lá, tem que ensinar espanhol, mas algumas vezes as variantes são de alguns lugares específicos então o professor tem que saber também que tal espanhol é assim e que quando ouvir alguém do lugar falando...

Pesquisador: E por que você acha que o professor tem que ensinar a variante que ele for mais seguro para ensinar, que ele sentir mais seguro?

Isabelly: É por que eu acho que ele não vai estar se engando e enganando os alunos. Por que muitas vezes ele vai errar se ele falar alguma coisa que ele não sabe, se for uma 
variante com a qual ele não tem intimidade de uso, ele vai falar alguma coisa que ele não sabe.

Pesquisador: Vai ficar artificial?

Isabelly: É, vai ficar artificial, vai ser como, vai ficar artificial...

Podemos observar, a partir da triangulação dos questionários e da entrevista, que essas crenças de Isabelly são propícias ao processo de ensinar e aprender línguas. Inclusive, ela se apresenta madura em relação à consciência de que o professor deve utilizar a variante na qual se sente mais seguro, esta crença da nossa participante vai ao encontro do conceito científico expresso em documentos oficiais como as OCEM do MEC (2006).

Em conversas informais, durante algumas atividades realizadas no início de 2013.2, percebemos que Isabelly compartilhava de uma crença muito comum entre estudantes brasileiros de espanhol. Para ela, a variação era uma característica do espanhol americano, já que o espanhol peninsular seria neutro e isento de variação. Na entrevista, realizada no final do semestre, após a análise preliminar dos dados, nossa participante reconheceu esta crença como não favorável ao processo de ensino-aprendizagem e relata a tomada de consciência transformadora via reflexão:

[Excerto 159]

Pesquisador: Se eu estiver enganado você me corrige, mas eu senti que em dezembro de 2012 você...

Isabelly: faz tanto tempo isso Fábio...

Pesquisador: Você pensava que o espanhol da Espanha era neutro, e o espanhol da América Latina era cheio de variação. Eu tô enganado ou era isso mesmo que você pensava?

Isabelly: Não sei, deixa eu ver o que eu escrevi...

Pesquisador: Mas o que você pensa?

Isabelly: Eu mudei de opinião...

Pesquisador: Você mudou de opinião?

Isabelly: É, nenhuma língua é neutra.

Pesquisador: Ah! Mas naquela época você pensava?

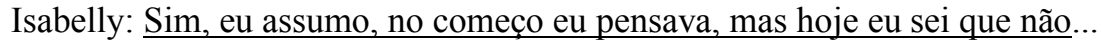

Pesquisador: Por que você mudou? Não é errado mudar.

Isabelly: Eu sei.

Pesquisador: A gente muda o tempo todo. Eu queria só entender por que você mudou.

Isabelly: Por que eu descobri que não é assim, né? Que a língua é igual às pessoas, está em constante mudança, metamorfoses, né? E existem vários tipos de variação, por que língua é língua e varia...

Pesquisador: $\mathrm{O}$ cinema te ajudou a desconstruir esta visão?

Isabelly: Ajudou né? Por que dá pra perceber as variedades culturais né? Do jeito de falar, mas também a forma como as pessoas se expressam, se relacionam.

Pesquisador: E dos filmes utilizados para trabalhar com a variação, de qual que você gostou mais? 
Isabelly: Agora de imediato eu não sei te dizer, porque foram muitos, eu assisti muitos filmes nos últimos anos com você aqui na UEPB, [risos] (Entrevista realizada no final do semestre 2013.2 - grifos nossos).

Neste caso específico, o cinema cumpriu o seu papel como mediador, de forma a promover momentos de reflexão propícios a (re)construção da crença de que o espanhol peninsular era neutro e o americano rico em variação. $\mathrm{O}$ fragmento a seguir ressalta isso:

[Excerto 160]

Pesquisador: Você fala que queria conhecer vários países para observar a variação, que por isso que você queria, para poder comparar um país com o outro. Só que quando você fala isso, não dá a impressão, quando você fala assim que quer conhecer três países diferentes e comparar a variação, não dá a impressão... A impressão que eu tenho é que você continua com a visão de que a variação ela é característica de cada país como um todo, e que ela - a variação - só vai acontecer de um país para o outro.

Isabelly: Não, não é isso, existem vários tipos de variação, tem a variação regional, de forma mais abrangente, que dá traços gerais a um país, mas dentro de cada país também tem várias outras variações, no tempo, no espaço, de pessoa para pessoa, entre pessoas de idades diferentes, sexo, essas coisas (Entrevista realizada no final do semestre 2013.2 grifos nossos).

Nossa participante se coloca e toma o turno de forma a argumentar com propriedade da consciência adquirida em relação a variação ser inerente a qualquer língua e em vários níveis. Neste sentido, sabemos e o discurso de Isabelly nos dá indícios desta consciência de que a variação em determinada língua pode ser classificada por critérios geográficos (variação diatópica), sociais (variação diastrática) e de estilo (diafásica). De acordo com Briz (1998), a língua varia no tempo e no espaço conforme as características dos usuários e da situação de comunicação. O contexto comunicativo regula e determina de alguma forma as condutas linguísticas e extralinguísticas dos interlocutores.

Em 1492, foi publicada na Espanha, a primeira Gramática, consagrando a frase de seu prólogo: “A língua é companheira do império”. E até hoje, tem chegado até nosso país não só capital internacional, mas também prêmios para o chefe de Estado ${ }^{92}$, muitos livros didáticos de grupos editoriais espanhóis e boas intenções para colaborar com a difusão da área de abrangência da língua e cultura ibérica em nosso território.

Ecos do discurso colonizador podem ser encontrados na fala de Isabelly. Nossa participante, em dezembro de 2012, foi questionada "Se você nunca esteve num país que fala,

\footnotetext{
${ }^{92}$ Luis Inácio Lula da Silva, presidente do Brasil na época, foi agraciado, em 2008, pelo governo de Castilla-La Mancha e pela Fundação Santillana, com a primeira edição do Premio Internacional Don Quijote de la Mancha de melhor trabalho institucional, como forma de reconhecimento pelo incentivo que a lei 11.161/2005 deu à língua espanhola em território brasileiro.
} 
qual país você gostaria de visitar: Por quê?”, como resposta, obtivemos a Espanha, conforme apresenta o excerto:

[Excerto 161]

Espanha, porque é o berço da língua (Isabelly - Sondagem efetuada em Dez/2012).

O mesmo formulário apresentava a pergunta "quando você fala em espanhol, você se sente como um falante: ( ) Latino americano ( ) espanhol. Comente, se julgar necessário:”. $\mathrm{Na}$ ocasião, ela marcou que gostaria de ser identificada como uma latino-americana e justificou:

[Excerto 162]

Por que são os que estão mais próximos do Brasil e, possivelmente, vamos ter mais contato (Isabelly - Sondagem efetuada em Dez/2012).

De imediato, nos pareceu contraditório que nossa participante tivesse "o berço da língua" como sonho de destino turístico, mas quisesse ser reconhecida como uma falante latino-americana já que estamos na América Latina e teríamos mais oportunidades de contato com os países vizinhos. Inquietou-nos justamente este ponto, se possivelmente, nossas maiores oportunidades de contato são com os latino-americanos, o que justificaria o desejo pelo continente europeu? Quais crenças estariam por trás desta escolha?

A mesma pergunta "quando você fala em espanhol, você se sente como um falante: ( ) Latino americano ( ) espanhol . Comente, se julgar necessário:” apareceu novamente numa sondagem aplicada em outubro de 2013, no início do componente curricular "Linguística Aplicada ao ensino da língua espanhola”. Desta vez, Isabelly marcou as duas opções, que gostaria de ser identificada como espanhola e como latino-americana, mas não justificou a resposta. Com isso, nossa curiosidade aumentou, a mudança na opção da participante seria um reforço de que as crenças são mutantes, dinâmicas e, neste sentido, teríamos um indício da expansão da consciência rumo à interculturalidade? Esta questão foi explorada na nossa entrevista final:

[Excerto 163]

Pesquisador: Você marcou que queria ser identificada como uma latino-americana, depois você marcou os dois [espanhola e latino-americana] e não justificou... ai eu fiquei pensando, por que será que ela mudou, que antes ela queria ser identificada como uma latino-americana, por que está mais próximo do Brasil e vai ter mais contato e depois quer se identificar tanto como uma espanhola quanto como uma latino-americana?

Isabelly: Eu quero ir para a Espanha [risos].

Pesquisador: Não, não tem problema nenhum você querer ir para a Espanha, é por isso? Isabelly: Não, não, é que eu tinha falado antes que eu acho que o espanhol é uma língua ampla, a gente não deve se limitar assim: espanhol daqui, espanhol de lá, claro que o 
espanhol é diferente, mas ao mesmo tempo é comum e devemos tentar falar e ser entendido das diversas formas.

Pesquisador: Você entrou em contradição, por que da primeira vez que foi perguntado... Isabelly: Eu mudei, eu não posso mudar?

Pesquisador: Sim, não tem problema, eu só estou tentando entender. Pode mudar. A gente muda o tempo todo. O ser humano é uma metamorfose ambulante...

Isbabelly: Eu conheço essa frase, é do Raul [risos]. (Entrevista realizada no final do semestre 2013.2 - destaques nossos).

Este trecho da entrevista reforça a nossa hipótese de uma possível expansão da consciência da nossa participante rumo à interculturalidade, o que poderia até ser reforçado pela sondagem realizada em outubro de 2013 quando, ao ser questionada "Se você nunca esteve num país que fala, qual país você gostaria de visitar: Por quê" ela responde:

[Excerto 164]

A princípio queria visitar três: Espanha, México, Chile ou Argentina (em dúvida). Para ver se consigo perceber as diferenças e variedades da língua e cultura (Isabelly Sondagem no início do componente curricular "Linguística Aplicada à Língua Espanhola", outubro de 2013).

Porém, ao longo da entrevista, à medida que foi se sentindo mais a vontade, nossa participante nos revela um conflito de crenças entre a visão de integração latino-americana e o reconhecimento da Espanha como local superior:

[Excerto 165]

Pesquisador: [risos] E em dezembro de 2012 você falou assim que você gostaria de conhecer a Espanha, certo? Só que aí em outubro de 2013 você falou vários outros países, a Espanha, o México...

Isabelly: O centro da língua.

Pesquisador: E mais outros países. Ai eu pensei, sim, mas como que ela quer conhecer a Espanha, mas quer ser identificada como uma falante latino-americana?

Isabelly: Hum...

Pesquisador: Tem uma contradição ai?

Isabelly: Depende, porque eu quero ser uma latino-americana que conheça também a variedade do espanhol da Espanha.

Pesquisador: Ah! Muito bom!

Isabelly: Entendeu? [Risos]

Pesquisador: Entendi, não é por que você quer ser identificada como uma latinoamericana que você precisa circular só pela América Latina, né?

Isabelly: É!

Pesquisador: É mesmo isso que você quis dizer?

Isabelly: É, com certeza

Pesquisador: Que chique. Então você quer ser uma latino-americana que conheça a América Latina e a Espanha?

Isabelly: Sim, a Espanha né? Que é o berço da língua.

Pesquisador: É o berço do espanhol?

Isabelly: Sim.

(Entrevista realizada no final do semestre 2013.2 - grifos nossos). 
A sensação que temos, neste momento, é de que Isabelly nos revela ter consciência do que seria o "mais" correto, ou seja, reconhecer e valorizar a nossa identidade latinoamericana. Porém, ainda existe um discurso de colonização linguística, já que conforme ressalta Calvet (2005), ainda hoje sofremos as consequências das relações entre discurso colonial e discurso linguístico, que fala mais alto ou deixa ela em contradição, ressaltando uma inconsistência entre o que ela pensa e o que acha que seria "certo" pensar.

Conforme destacamos na fundamentação teórica, Posner et. al. (1982) argumentam que a insatisfação com determinada crença existente é o ponta pé inicial para que ela seja substituída por outra. No caso de Isabelly, é bem provável que não a insatisfação, mas sim o incômodo, a inconsistência gerada por duas crenças, inicialmente conflituosas entre si (consciência da necessidade de constituição e fortalecimento de uma identidade latinoamericana versus Espanha como pertencente ao continente europeu e berço da língua), possa ser o dispositivo motivador para futuras rupturas, (re)significações e (re)arranjos em seu sistema de crenças.

Em outras palavras, a impressão que temos é de que ela ainda luta para administrar internamente o conflito entre a consciência da integração e a crença da superioridade linguística da Espanha, como continente europeu e como berço da língua, o que a coloca, inclusive, com uma crença de síndrome de inferioridade como colonizada e nos desperta outra hipótese: diante da dificuldade de se alcançar um patamar de excelência linguística da variante falada no berço da língua (que, inclusive, como ela nos relatou no excerto 159, durante um tempo ela teve a crença de ser a variante peninsular neutra e isenta de variações), ela se conforma em falar como um latino-americano, já que por ser colonizado e por ser a América Latina um campo diverso e cheio de variações, a tolerância ao erro seria maior. A crença do povo colonizado como inferir pode ser observada no excerto a seguir:

[Excerto 166]

Pesquisador: primeiro você falou que queria conhecer a Espanha, em dezembro de 2012. Isabelly: É, por ser a Europa, e a Europa tem mais prestígio.

Pesquisador: E você quer passear né?

Isabelly: É, eu quero andar.

Pesquisador: Se tem prestígio você também quer estar prestigiada? Isabelly: [Risos].

Pesquisador: E por que você acha que tem mais prestígio?

Isabelly: Por ser a Europa, por ser de lá que o espanhol veio, né? Os colonizadores vieram de lá para a América, então eu acho, eles são os conquistadores e nós os conquistados.

Pesquisador: Uma coisa que vem já de muito tempo?

Isabelly: É, algo histórico.

(Entrevista realizada no final do semestre 2013.2 - grifos nossos). 
Nossa participante apresenta indícios da consciência de se promover, via ensino de ELE, uma consciência de América Latina para além de uma construção geográfica, porém, ainda apresenta conflitos e dificuldade em "abandonar" a crença da Espanha como "berço da língua", lugar de "destaque" e "prestígio". Neste sentido, Barcelos (2007) relaciona o conceito de mudança de crenças a vários outros sentimentos como dúvida, incerteza, ambiguidade, caos. Dessa forma, acreditamos que ter propiciado à nossa participante momentos de reflexão que desestabilizassem suas certezas e colocasse seu sistema de crenças em inspeção consciente já representa um grande avanço e uma conquista significativa para a nossa investigação, já que a mudança é um processo lento, demanda tempo e é resultado de um processo de reflexão que inclui novas formas de pensar e compreender nossas ações.

Nesta mesma linha, relembramos que as “crenças não só representam uma realidade social, mas constroem essa realidade" (KRAMSCH, 2003) e, dessa forma, não devemos ocultar a inconsistência e variabilidade das delas, mas promover uma reflexão contextualizada, levando em conta sua variabilidade, contingência e inconsistência.

Nesta mesma linha, Blatyta (1999) apresenta que as mudanças implicam reflexão constante e contínua, que demanda uma visão crítica que se constrói a partir do desequilíbrio provocado pelo confronto com outras alternativas, pela análise das contradições e pelo conflito provocado por visões diferentes.

Ao mesmo tempo em que Isabelly apresenta, em seu discurso, uma "evolução" rumo à diversidade, este discurso está, por diversas vezes, permeado por certo preconceito em relação aos países "pobres". Na sondagem realizada uma semana antes de trabalharmos com a sequência didática da Bolívia, quando questionada "O que você sabe a respeito da Bolívia e dos bolivianos?, nossa participante respondeu:

[Excerto 167]

Un país pobre, poco alfabetizado, la mayoría es indígena.

Você sabe algo a respeito dos bolivianos no Brasil?

Son vistos como mala gente en Brasil. También muchos bolivianos trabajan en Brasil de forma clandestina (Isabelly, Sondagem a respeito da Bolívia, 07/02/2014).

Este excerto fortalece a nossa hipótese de que o discurso "a língua é companheira do império" reverbera no sistema de crenças da nossa participante. 


\subsection{Lourdes Maria}

Lourdes Maria tem 26 anos, é brasileira, solteira, tem dois irmãos e sempre morou na zona rural, nas proximidades de Monteiro. Por conta disso, precisa viajar todos os dias e, como não tem transporte que até o sítio, ela e alguns colegas da zona rural compartilham uma casa para passarem alguns dias da semana na cidade de Serra Branca. Os pais não passaram por escolarização formal, ela cursou o ensino fundamental e médio todo em escola pública, frequentou cursinho pré-vestibular durante um ano e nunca viajou para o exterior.

Além de ter estudado inglês na escola, ela sempre se empenhou em tentar aprender esta língua por conta própria. Ela possui computador, mas não tem conexão com a internet em casa, nunca foi ao cinema, não tem o hábito de baixar filmes da internet, mas relata ter o costume de assistir a filmes com certa frequência. Apresentamos a autobiografia de Lourdes Maria, que será comentada a seguir.

Minha historia de aprendizagem da língua espanhola se iniciou na infância, meu primeiro contato não foi o que se possa chamar de uma boa impressão. Por causa do meu nome meus colegas costumavam me apelidar e rir de mim porque se assemelhava ao do Júlio Iglesias e isso me incomodava constantemente. A princípio, eu odiava tudo que fizesse relação ao "pobre" Júlio Iglesias e o idioma espanhol não estava descartado da minha lista de ódio. Sempre que alguém falava um ¡Hola!, ;Buenos días!, logo vinha a minha mente o bendito do Iglesias, nem mesmo minha ida ao Ensino Médio modificou a situação, achei que essa alteração mudaria as coisas, engano meu, os alunos eram bem maiores e mais insistentes nos apelidos e brincadeirinhas, mal sabia eu que aquilo era "bullying". Na verdade, a única coisa que eu sabia era que a culpa foi toda da minha mãe que, com tantas opções de nomes, resolveu inventar um que era, no mínimo, estranho.

Com o passar dos anos, ao invés de me acomodar e aceitar de uma vez os pedidos insistentes e constrangedores para cantar as músicas do Júlio Iglesias, resolvi tomar uma atitude em relação à oportunidade que me foi oferecida, eu não conhecia nada daquele homem nem de seu lugar de origem e porque não conhecer? no mínimo eu ia ganhar em termos de conhecimento e isso não seria ruim. Comecei a ouvir suas músicas, ler coisas em espanhol e me encantei pela cultura espanhola tão rica e múltipla com seu idioma falado em diferentes países.

Quando terminei o terceiro ano do ensino médio tive alguns problemas de saúde e perdas na família. Problemas esses que me fizeram ficar longe das salas de aula durante cinco anos. Eu continuei a ler livros de inglês e espanhol, textos e testes de vestibular para que eu continuasse informada e não apenas para me distrair. Cheguei a um ponto que sair de casa era um sacrifício, fui diagnosticada com princípio de depressão e saber disso só me desmotivou, porque eu queria acreditar que tinha algum problema físico que com um simples remédio fizesse aquela dor interior passar. $\mathrm{Eu}$ decidi não tomar remédios e a arranjar um motivo pra levantar, por mais difícil que aquilo parecesse, o meu motivo foi estudar. No ano de 2009 me matriculei na seleção para o cursinho pré-vestibular e passei em primeiro lugar para a alegria do meu pai que nunca desistiu de mim.

Minha primeira aula no cursinho foi de língua espanhola, com um colombiano. Não esqueço aquele professor porque além dele só o Júlio Iglesias que tinha me conectado ao espanhol. Passei 07 anos estudando língua inglesa no colégio, adorava inglês, mas nunca, 
em toda minha vida, fiquei tão empolgada em conhecer um idioma como me senti naquela manhã de domingo em 2009. Parece pouco, eu sei, mas para alguém que acreditava não ter mais sentido na vida, alguém que nunca saiu do seu sítio e que não havia visto nada de diferente da sua cultura interiorana durante todos os vinte anos de sua vida, para esse alguém era um passo largo e extremamente importante, foi como viajar no tempo e no espaço. Sabe o que foi mais incrível? na nossa primeira atividade no cursinho havia uma música para reconhecermos as palavras semelhantes ao português e grifarmos as que não entendêssemos, e a música era do Júlio Iglesias, eu sei ele vai me perseguir pelo resto da vida, mas naquele dia falar sobre ele não foi constrangedor, ao contrário, eu já conhecia suas músicas e isso me facilitou na hora de responder e reconhecer algumas palavras.

Ao terminar o cursinho eu não tinha dúvidas: "Letras-Espanhol" seria minha opção no vestibular. Como falei anteriormente, eu fui aprovada no vestibular e passei e há quatro anos curso Letras-Espanhol na UEPB e esses têm sido os melhores anos de minha vida: conhecer novas pessoas, culturas e aprender sobre o que gosto, a língua espanhola, não há nada melhor do que fazer aquilo que se ama e eu posso falar isso porque estudo o que me dispus a amar.

Contudo, ainda sinto que mesmo fazendo o que gosto encontro certa dificuldade porque nosso contato com a língua não é o quanto nós queríamos e precisávamos. Não culpo o campus, acredito que, como tudo em nossa vida, nada acontece por acaso e essa também é uma questão da qual devemos correr atrás para que possamos alcançar nossos objetivos. Afinal, nada cai do céu, até mesmo a chuva precisa passar por todo um processo de acúmulo, evaporação, formação de nuvens e depois sua descida ao solo, precisamos passar por um processo e isso cabe a nós, uma procura por conhecimento, estarmos sempre em contato com o novo.

Bom, esse tem sido meu ponto de apoio para tentar me erguer, eu sei que não é o bastante e eu não quero o bastante, nem perfeição até porque um dia alguém me disse que o perfeito é algo com forma acabada, pronta e como aprendi que nada está acabado, estamos sempre em construção, eu prefiro estar sempre me construindo. Desejo cursar o mestrado, o doutorado e ir mais além. Tenho um sonho de conhecer diferentes idiomas e suas culturas respectivamente, o inglês será o meu próximo passo e como termino o meu curso em agosto do ano que vem o próximo vestibular que me aguarde porque isso é só o começo, a menina do interior deseja conhecer o mundo. Talvez eu nunca saia da Paraíba, mas eu sei que estudando o mundo virá até mim (Autobiografia de Lourdes Maria, elaborada no final do semestre letivo).

A autobiografia da Lourdes Maria nos apresenta uma relação fundante com a língua de Cervantes não muito favorável à aquisição/aprendizado. Pelo fato de ter seu nome muito próximo ao nome de um cantor espanhol e, como consequência, desde muito cedo, na escola, ter sofrido bullying por parte dos colegas, ao adquirir certa repulsa ao cantor, ela estendeu este descontentamento à língua e cultura espanhola.

Em determinado momento de sua vida a participante quis tornar aquela experiência negativa em algo positivo e revolveu aprender, pesquisar a respeito daquele cantor e sua cultura. Na busca por novos conhecimentos, ela conheceu as músicas de Julio Iglesias, começou a ler coisas em espanhol e se encantou pela riqueza e multiplicidade cultural dos países em que esta língua é falada. 
Mesmo quando fora da educação formal, a participante continuou estudando línguas (inglês e espanhol) por conta própria. O segundo contato dela com o espanhol foi no cursinho pré-vestibular: "minha primeira aula no cursinho foi de língua espanhola, com um colombiano. Não esqueço aquele professor porque além dele só o Julio Iglesias que tinha me conectado ao espanhol".

Voltar a estudar, frequentar o cursinho e, depois, cursar Letras-Espanhol representou, para a nossa participante - "que nunca saiu do seu sítio e que não havia visto nada de diferente da sua cultura interiorana durante todos os vinte anos de sua vida" - a abertura para novos horizontes e possibilidades, "como viajar no tempo e no espaço", foi uma forma de encontrar sentido para a vida e dispor-se ao novo.

Podemos observar, em Lourdes Maria indícios de uma postura inquieta, que sempre deseja novos conhecimentos e está aberta ao novo. Ao se referir ao curso de Letras-Espanhol, ela relata que "têm sido os melhores anos de minha vida: conhecer novas pessoas, culturas e aprender sobre o que gosto, a língua espanhola, não há nada melhor do que fazer aquilo que se ama".

A participante tem consciência da limitação de oportunidades para contato com nativos e de situações reais de uso da língua, que são escassas na região: "nosso contato com a língua não é o quanto nós queríamos e precisávamos”, mas sua postura é de sujeito ativo, responsável pela sua aprendizagem, já que "devemos correr atrás para que possamos alcançar nossos objetivos. Afinal, nada cai do céu".

E, nesta busca constante pelo conhecimento, ela sabe da importância de "estarmos sempre em contato com o novo" e tem consciência das limitações e incompletude de todo ser humano: "aprendi que nada está acabado, estamos sempre em construção, eu prefiro estar sempre me construindo". Ela relata ter o sonho de conhecer outras línguas e culturas e da importância de estar disposta ao novo: "a menina do interior deseja conhecer o mundo. Talvez eu nunca saia da Paraíba, mas eu sei que estudando o mundo virá até mim”. Essa postura de abertura a novas aprendizagens perpassou todas as atividades da participante oferecidas ao longo do semestre 2013.2. 


\section{Crenças a respeito de processo de adquirir/aprender o E-LE}

A partir de conversas informais e do log registrado durante o filme Albergue Espanhol, podemos perceber que Lourdes Maria demonstra ter uma crença favorável ao processo de ensino-aprendizagem: nossa participante percebe cultura e identidade como algo amplo, dinâmico, instável e fragmentado, o que condiz com as visões contemporâneas que buscam compreender o complexo processo de ensinar e aprender línguas:

[Excerto 168]

No hay una única Identidad. Es una construcción continua (Log Albergue Espanhol Lourdes Maria 01/11/12).

Outros logs registrados pela participante ao longo dos filmes nos dão indícios de que ela acredita que a afetividade exerce um papel relevante no processo de aprender e ensinar uma língua:

[Excerto 169]

Ao se estabelecer relações afetivas/amizade a aprendizagem flui mais rápido (Log Albergue Espanhol - Lourdes Maria 01/11/12).

[Excerto 170]

A dor ou a alegria, de certa forma, une aos desconhecidos. Os sentimentos não têm fronteiras, nem barreiras linguísticas (Log Um conto chinês - Lourdes Maria 08/11/12).

Dentre as várias crenças de puderam ser explicitadas por Lourdes Maria durante a exibição dos filmes, pudemos perceber que ela tem consciência da importância da subcompetência estratégica no processo comunicativo:

[Excerto 171]

Sentir-se perdido - não poder se comunicar, ser entendido. Gesticular para ser compreendido - mímicas (Log Um conto chinês - Lourdes Maria, 08/11/12).

Este log trás indícios do reconhecimento, por parte da nossa participante, da importância da subcompetência estratégica para a comunicação/sobrevivência na LE, bem como a necessidade da prática da alteridade e da aculturação no processo de integração à uma nova cultura.

[Excerto 172]

Imitar as ações, gestos, forma de comer. As ações [de Roberto] são repetidas [por Jun] quase como num espelho (Log Um conto chinês - Lourdes Maria, 08/11/12).

[Excerto 173]

Perceber os gestos, as expressões faciais, ajuda a entender a língua (Log do filme Espanglês - Lourdes Maria). 
Os logs de Lourdes Maria nos dão indícios de que ela tem, ou está construindo, crenças favoráveis ao processo de aquisição/aprendizagem como as de que o não verbal e o engajamento com o Outro seria tão importante quanto o verbal no processo de aquisição/aprendizado de uma língua estrangeira.

[Excerto 174]

Cristina é uma ótima tradutora, está de parabéns. Interessante como ela imita os gestos, as expressões, a entonação da voz, tudo para manter a interação e intermediar o contato entre pessoas (Log do filme Espanglês - Lourdes Maria).

A postura positiva da nossa participante diante do complexo processo de aprender e ensinar uma língua nos indica uma consciência/crença de que adquirir/aprender uma língua vai muito além de questões da ordem do linguístico.

\section{O tratamento da unidade e da diversidade no ensino de E-LE para brasileiros}

$\mathrm{Na}$ entrevista realizada no final do semestre, Lourdes Maria reconhece que tinha preconceitos e estereótipos negativos e argumenta ter (re)construído esta visão ao longo do semestre:

\section{[Excerto 175]}

Pesquisador: Como você resumiria as nossas experiências ao longo deste semestre? Lourdes Maria: Eu achava que o espanhol desses países como a Bolívia, Paraguai, esses países, era um espanhol pobre e que por isso não podia ser usado para ensinar sabe? Porque eles não tinham, né? Não tinha um bom espanhol... só depois me dei conta de como são ricos linguisticamente quando a gente aprende sobre a Bolívia e a riqueza cultural daquele povo e o Paraguai que a gente vê num filme como o 7 cajas a facilidade com que as pessoas falam, e falam alternado as línguas, entre o guarani, o espanhol e a mistura dessas duas línguas e, e não alternam de qualquer jeito e nem ao acaso, mas sim, é consciente, de acordo com a situação e o interesse na comunicação, a gente se dá conta da riqueza e das muitas línguas da região (Lourdes Maria. Entrevista de encerramento das atividades, após uma análise preliminar dos dados).

O cinema atuou como mediador no sentido de despertar uma consciência dos diversos níveis de bilinguismo e da riqueza linguística da América Latina por meio da questão do bilinguismo no Paraguai, a partir do filme 7 cajas. A questão foi percebida e registrada por Lourdes Maria em logs durante a exibição do filme:

[Excerto 176]

Mezcla de lenguas habladas de acuerdo con la situación. Solamente se usa determinada lengua si en el contexto social se hace necesario.

Liz é uma pessoa muito inteligente, fala em bom espanhol no momento em que Victor deixa mercadoria sozinha e eles se sentem ameaçados por Nelson.

Quando é necessário Victor fala em espanhol.

Tamara fala muito em espanhol quando conversa com a médica a respeito de sua amiga Leti. 
Para falar com a Virgem Maria Victor usa o espanhol. Seria o espanhol para ele a língua do formal e do sagrado? (Logs - 7 Cajas - Lourdes Maria, 27/02/14).

Dito de outra maneira, os logs registrados por Lourdes Maria podem ser considerados como indícios do despertar e, neste caso, um despertar mediado pelo cinema, que apresentou um contexto verossímil de usos, da consciência dos diversos níveis de bilinguismo e da riqueza linguística da América Latina e que podem e devem ser considerados nas políticas de ensino e integração regional, conforme discutimos em sala e apresentamos no capítulo 3 desta tese baseados, principalmente, em Arnoux (2008, 2010, 2012).

Sabemos que estamos diante de um processo - o da possível (re)construção de crenças - complexo, que envolve muitas variáveis e só pode ser observado ao longo do tempo, via mediação que propicie a autorreflexão, auto inspeção consciente do sistema de crenças e a análise de discursos e ações.

Neste sentido, temos consciência que o período de um semestre, como foi desenvolvida a nossa investigação, não é suficiente para traçar conclusões definitivas. Porém, podemos afirmar que as crenças, sempre que em contato com novas experiências, passam por um processo de (re)significação, tendo como dispositivos desencadeadores questionamentos, reflexões, dúvidas, conflitos que geram a (re)construção de conhecimentos, informações e aprendizagens.

Dessa forma, nossa pesquisa ganha relevância ao utilizar o cinema como mediador do desencadeamento de reflexões a respeito de como se ensina e se aprende o E-LE. Na entrevista final, Lourdes Maria relata outra expansão, via reflexão, que merece destaque:

[Excerto 177]

Pesquisador: Como você resumiria as nossas experiências ao longo deste semestre?

Lourdes Maria: Foi um semestre de aprimoramento, a gente cresceu, né? Eu sempre pensei, sabe? que a gente, que quando a gente, quando ia ter uma disciplina relacionada a língua, linguística aplicada, montar um curso, um plano de ensino, deveria organizar por uma ordem gramatical, né? Assim, tipo, seguindo a ordem dos pontos de gramática que a gente deve aprender ou ensinar, mas, com essas experiências, com essas atividades que a gente fez ao longo desse período, eu aprendi que a gente pode partir de tópicos culturais, geográficos, territórios, países, a gramática é importante, muito importante, mas não é tudo (Lourdes Maria. Entrevista de encerramento das atividades, após uma análise preliminar dos dados).

Podemos perceber, neste excerto, que a crença da gramática como eixo temático direcionador de um curso de línguas começa a ceder espaço para outras crenças, como a de 
que momentos, territórios, grupos sociais e legados culturais, como destaca Serrani (2005), podem ser temas geradores da organização de sequências de aprendizagem.

No que concerne à temática da diversidade e da reação diante do outro, Lourdes Maria reagiu de forma positiva à exibição e as oportunidades de reflexão mediadas pelo filme cubano. Quando questionada se acredita ser Morango e Chocolate um bom título, a resposta dela é completamente oposta à de Ana Cecília, apresentada no excerto 130:

[Excerto 178]

Creo que es un título singular, ya que relaciona los alimentos a las características de los personajes (Atividade após a exibição de Fresa y chocolate - Lourdes Maria - 07/02/14).

A reação de Lourdes Maria é positiva no sentido de conviver com a diversidade. Neste sentido, ela registrou os logs:

[Excerto 179]

A diversidade apresentada no filme é muito interessante, pois se pode ver que pode haver amizade entre um heterossexual e um homossexual.

El abrazo emocionado de los personajes que al fin se entendieron en sus diferencias (Logs Fresa y chocolate - Lourdes Maria, 07/02/2014).

Durante as reflexões mediadas pelo episódio "Dia da Independência" que relata a situação de alguns bolivianos vivendo em São Paulo, Lourdes Maria demonstrou atitudes positivas no sentido de percepção da convivência com o outro e da aceitação necessária para uma política de integração regional.

Diante da atividade em que deveria comentar a relação entre língua e identidade na conversa entre Checo e seu padrasto, quando o garoto é surpreendido tentando recuperar os passaportes roubados dos funcionários que estão sendo explorados, ele fala em português e o padrasto, irritado, insiste que ele fale “-En español, carajo", Lourdes Maria teve uma postura de sensibilidade, assim como Ana Cecília apresentou no excerto 133. Vejamos:

[Excerto 180]

Aqui percebemos a questão da não interação entre os dois idiomas, eles se situam em extremos, em momentos tão próximos, mas na realidade distantes já que não procuram entender um ao outro, apesar de Checho compreender o espanhol e o seu padrasto o português ambos se recusam a mudar seus hábitos linguísticos para se envolver no espaço do outro (Atividade filme após a exibição do episódio Dia da Independência, da série Destino São Paulo - Lourdes Maria - 28/02/14).

Lourdes Maria demonstra, neste excerto, a crença positiva de que para conviver e, consequentemente adquirir/aprender uma língua estrangeira faz-se necessário interagir e 
praticar a alteridade, no sentido de ser outro, colocar-se no lugar do outro. Sendo, portanto, a disposição e o engajamento fundamental neste processo.

Nossa participante registra uma postura positiva de compreensão de um conflito identitário diante da reflexão a respeito do momento em que a mãe de Checho prepara roupas para uma festa típica e também quando a professora tem a intenção de promover a cultura dele na escola:

[Excerto 181]

Checho não reage positivamente, é como se ele não quisesse fazer parte daquela cultura e com a professora ele, a princípio, se mantém distante das intenções dela. Ele mantém uma postura de negação da sua cultura, porque na escola mantém um contato com o português e em casa com o castelhano, ficando assim em uma zona intermediária que se desprende do português e do castelhano é como se fosse uma terceira cultura que se apropria das duas anteriores para se solidificar. Por isso ele se sente distante da sua cultura e nega a cultura boliviana (Atividade realizada após a exibição do episódio Dia da Independência, da série Destino São Paulo - Lourdes Maria - 28/02/14 - grifos nossos).

Nossa participante apresenta uma consciência voltada ao contexto de integração e as várias subjetivações envolvendo línguas, territórios e migrantes. Lourdes Maria tem consciência, ainda que sem utilizar os conceitos científicos, que conhecer uma nova língua e, consequentemente, suas culturas, envolve a construção de uma terceira margem (nos termos de Guimarães Rosa) e que, no caso dos bolivianos em São Paulo, essa população busca a construção de um "entre-lugar", conforme foi trabalhado em sala, antes da exibição do filme, a partir da apresentação da feira Kantuta e de algumas discussões teóricas de Bhabha (1998).

Até este ponto, conforme podemos observar no excerto 134 de Ana Cecília, as reflexões das duas participantes convergem. Porém, Ana Cecília, nos excertos 135 e 136, se mostrou isenta de alteridade durante o trecho do episódio em que a mãe de Checo é convocada a comparecer na escola e é humilhada pelo diretor por não estar falando em português, já que estamos no Brasil e seria obrigação dela se expressar no idioma nacional.

Quando questionada a respeito de como ficam as relações de poder na e pela linguagem durante esta conversa, Lourdes Maria responde:

[Excerto 182]

Essa relação não é positiva, pois uma língua acaba que excluindo a outra, há um preconceito por parte do diretor (Atividade filme após a exibição do episódio Dia da Independência, da série Destino São Paulo - Lourdes Maria - 28/02/14).

Já em relação à pergunta "Na conversa com a direção era, de fato, necessário falar português, como enfatizou o diretor? '. Lourdes Maria apresenta uma postura crítica, mas não tão isenta de alteridade como Ana Cecília: 
[Excerto 183]

Podia-se falar português, mas não era realmente necessário. O diretor foi insensível em relação à mãe de Checho (Atividade filme após a exibição do episódio Dia da Independência, da série Destino São Paulo - Lourdes Maria - 28/02/14).

Quando interpelada a se manifestar a respeito da postura do diretor, Lourdes Maria argumentou:

[Excerto 184]

O diretor teve uma postura "infeliz", pois tratou a mãe de Checho como intrusa no país que deveria a toda custa se adaptar a situação, não percebeu que ele também tinha um papel importante neste contexto (Atividade filme após a exibição do episódio Dia da Independência, da série Destino São Paulo - Lourdes Maria - 28/02/14).

\section{Constituição da identidade docente}

Em conversas informais ao longo do semestre, na autobiografia e numa atividade de reflexão que apresentaremos a seguir, Lourdes Maria sempre se mostrou inquieta e batalhadora diante das adversidades, de forma a ter uma postura sempre aberta e tolerante ao novo e ao diferente. É comum, também, encontrarmos no discurso dela crenças positivas a respeito da profissão docente:

[Excerto 185]

Em uma época difícil medidas desesperadoras devem ser tomadas, desistir dos seus objetivos e encarar uma vida tranquila sem mais atribulações ou prosseguir mediante esforços tremendos como enfrentar a chuva e o sol forte em estradas de areia, correndo riscos por ter como transporte um pau de arara, isso poderia até desestimular alguém, mas não alguém que deseja mudar o seu futuro. Esses obstáculos foram enfrentados por mim e por muitos dos meus amigos da zona rural para que pudéssemos estudar, pois eu tinha um sonho, o de fazer um curso que não apenas modificasse a minha vida, mas que a partir dele eu pudesse fazer algo por outras pessoas [...] Hoje meu sonho é poder concluir meu curso de Letras-Espanhol e fazer dele um instrumento que modifique a vida de outros, ensinando não apenas conceitos básicos da disciplina, mas também as questões de conhecimento de mundo e experiências pessoais (Lourdes Maria, atividade de reflexão realizada durante o componente estágio supervisionado - destaques nossos).

$\mathrm{Na}$ sondagem que antecedeu a unidade didática em que abordamos a temática da Bolívia, questionamos: "O que você sabe a respeito da Bolívia e dos bolivianos?”, a resposta da nossa participante mais uma vez ressalta a abertura dela à novas experiências e conhecimentos:

[Excerto 186]

Não sei quase nada sobre a Bolívia, mesmo sendo um país próximo ao nosso, nenhum ponto havia me chamado a atenção para que eu pudesse pesquisar sobre o país, mas eu gosto de aprender coisas novas e posso descobrir... (Lourdes Maria - Sondagem a respeito da Bolívia). 
Conforme podemos observar na autobiografia dela, o primeiro contato com o espanhol foi vinculado à variante peninsular, mas teve contato posterior com um professor colombiano no cursinho e sempre está disposta ao novo. A Postura aberta ao outro, ao conhecimento, ao aprendizado, às novas experiências e ao desejo de constituir-se enquanto professora ecoa no sistema de crenças de Lourdes Maria e ela tem consciência do seu papel como mediadora intercultural:

[Excerto 187]

Meu desejo é que essa jornada não pare na faculdade (...) que eu consiga continuar com o sonho de querer aprender sempre mais e aplique isso no meu dia a dia, dentro e fora da escola. É o nosso contato com o outro que nos engrandece, modifica opiniões e fortalece outras, saber ouvir e poder falar quando julgamos necessário são elementos que um professor deve ter para que haja troca de conhecimentos (Lourdes Maria, atividade de reflexão realizada durante o componente estágio supervisionado - destaques nossos).

O excerto a seguir, extraído do plano do minicurso ministrado pela participante como atividade do componente curricular "Estágio Supervisionado", nos dá um exemplo dos possíveis frutos do investimento numa postura reflexiva dos professores em formação sem dar ênfase ao treinamento com técnicas bem sucedidas de ensino:

[Excerto 188]

Em relação à escolha do tema a ser trabalhado, não terá uma temática específica pois, por mais que seja planejado, isso desde o plano de curso aos planos de aula sempre ocorrem modificações e o professor deve estar atento a essas mudanças, ou seja, o mesmo deve ser flexível (Plano de curso "primeiro contato com o espanhol". Lourdes Maria, novembro de 2013).

O minicurso ministrado por Lourdes Maria contava com vídeos curtos como temas geradores, mas não tinha uma estrutura pré-estabelecida, as aulas foram todas planejadas e direcionadas ao longo do processo de acordo com o público e os interesses que iam surgindo no grupo.

\section{Algumas contribuições do cinema no desenvolvimento do aprendiz reflexivo}

Em nosso embasamento teórico, comentamos o potencial do cinema como ferramenta e prática social propícios para o exercício da reflexão e da intertextualidade. Existe uma cena do filme 7 cajas em que Victor, nosso protagonista, recebe uma proposta inusitada: transportar sete caixas, sem conhecer seu conteúdo, em troca de uma nota rasgada de 100 dólares: metade é recebida como sinal e a outra metade do dinheiro seria entregue quando terminasse o seu trabalho. 


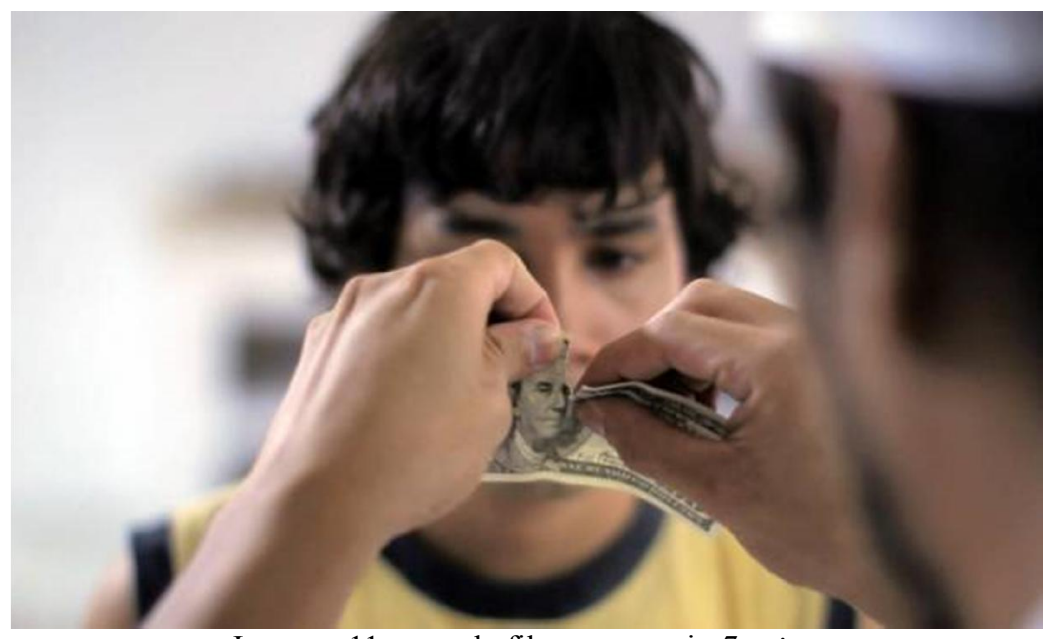

Imagem 11: cena do filme paraguaio 7 cajas.

Neste momento, Lourdes Maria registrou um log que nos dá indícios de que o cinema conseguiu aguçar os sentidos da nossa participante para, a partir da multiplicidade de sentidos possíveis em uma obra de arte, estabelecer um intertexto com o sagrado:

[Excerto 189]

Gostei da parte de rasgar o dinheiro. Era como Jesus repartindo o pão, só que de uma versão agora capitalista. (Log 7 cajas - Lourdes Maria, 27/02/14).

O cinema, se bem utilizado, com intencionalidade e planejamento prévio e não simplesmente - ao acaso, tem o poder artístico de humanizar. A sétima arte possibilita reunir diversos contextos em um só local, a sala de aula, e pode mostrar distintas realidades possíveis, de forma a desconstruir estereótipos negativos e mediar o encontro com o outro. Pode possibilitar a construção de novos conhecimentos, como a consciência de uma América Latina multicultural e plurilíngue e, ao mesmo tempo, a reflexão a respeito da implicação disso tudo no ensino de espanhol para brasileiros, como podemos observar nos excertos:

[Excerto 190]

A partir desse filme foi possível conhecer mais da cultura peruana e não apenas ver o lado léxico da questão, sentir como vivem as pessoas, seus sotaques e a forma com falam além, é claro, de conhecer um pouco da geografia do país já que nem todo mundo tem condições de viajar pra fora do país (Lourdes Maria - logs de "El misterio del kharisiri").

Este excerto confirma justamente esta possibilidade do cinema em apresentar, em um só suporte, diversas realidades e nos apresenta dimensões da importância de se promover, num contexto isolado geograficamente e sem a prática da cultura audiovisual como é o nosso, o cinema, enquanto artefato semiótico mediador, no processo de desenvolvimento do aprendiz reflexivo. 
Conforme Lourdes Maria citou em sua autobiografia, "a menina do interior deseja conhecer o mundo. Talvez eu nunca saia da Paraíba, mas eu sei que estudando o mundo virá até mim" e sabemos que o cinema pode ser o porta-voz desses muitos outros mundos possíveis.

[Excerto 191]

Gostei de ver como é a cultura peruana com seus rituais a partir o uso da folha de coca, ver que ela não serve apenas para fins de consumo e sim para firmar ainda mais o estilo e cultura de um povo (Lourdes Maria - logs de "El misterio del Kharisiri").

As experiências com a participante ao longo do semestre nos permitem afirmar que Lourdes Maria se mostrou aberta a ter várias experiências com o outro, representado, neste caso, pelo cinema, utilizado na pesquisa como artefato semiótico mediador. Neste sentido, a simbiose de conhecimentos novos com os antigos a partir do engajamento em atividades significativas "pode gerar novas configurações que mexem com a visão, com a perspectiva da pessoa, gerando uma modificação no próprio modo de pensar" (BLATYTA, 1999, p. 78). A reflexão é um ato de emoção que pode possibilitar a abertura do sistema de crenças à inspeção de forma a ver e tomar consciência de perspectivas que muitas vezes antes não víamos.

\subsection{Considerações}

O mundo é heterogêneo por natureza e, no nosso contexto, não seria diferente. Como pudemos observar, as pessoas são diferentes e percebem o mundo de maneiras distintas. Dessa forma, a massa heterogênea é a liga social necessária para que uns acelerem o desenvolvimento dos outros. Dito de outra maneira é importante que os cursos de formação inicial e continuada de professores, bem como as escolas, promovam equipes multidisciplinares de ensino com professores e alunos com crenças distintas e em diferentes estágios de desenvolvimento, proporcionando a constituição de comunidades de aprendizagem heterogêneas em que um atue como "mediador mais capaz", auxiliando e potencializando o desenvolvimento do outro.

Diante do exposto, acreditamos ser necessário em nossa prática como docente de E-LE e formador de professores deste idioma, continuar trabalhando com estas temáticas de forma a buscar conscientizar os participantes, via reflexão, a respeito dos vários níveis de bilinguismo que perpassam e, portanto, devem ser pensados no processo de integração latino-americana; 
da questão da integração a partir dos fluxos migratórios no Brasil do século XXI e da necessidade de se pensar numa educação bilíngue neste contexto.

Pudemos observar que o processo de reflexão das nossas participantes foi carregado de dúvidas, idas e voltas. Parece haver um conflito constante entre as crenças arraigadas e os novos olhares propiciados com a mediação do cinema, o que nos leva a perceber que estamos diante de um processo bastante complexo.

Buscamos estimular nossas participantes a refletir a respeito das concepções de linguagem, língua, língua estrangeira e ensino-aprendizagem de línguas, bem como o papel do cinema neste processo de forma a promover uma formação inicial voltada para o desenvolvimento das competências do professor.

Quanto à nossa pergunta de pesquisa: "se e como se transformam, com a mediação do cinema, as crenças de professores de espanhol em formação inicial acerca do processo de aquisição/aprendizagem da língua estrangeira e do tratamento da unidade e diversidade linguística no ensino de espanhol-língua estrangeira para brasileiros?", os resultados desta pesquisa mostraram que as pessoas reagem de maneira diferente aos diferentes estímulos para reflexão, (re)significação e (re)construção de crenças e, portanto, estamos diante de um processo complexo e de evolução gradativa. O cinema possibilitou, na maioria das oportunidades, a expansão do olhar e do sentir.

Diante da localização geográfica do campus em que atuamos, afastado de grandes centros urbanos, da dificuldade de acesso à internet de muitos de nossos alunos e da baixa renda da maioria deles, temos que destacar a importância que cumprem os meios alternativos e a universidade em propiciar ao nosso público o acesso à cultura audiovisual.

Difundir a riqueza da variação linguístico-cultural experiementada pela língua espanhola deve continuar sendo nossa meta. Buscaremos, com a mediação do cinema e demais atividades estrategicamente planejadas, promover via ensino, pesquisa e extensão a redescoberta do valor humano e artístico das criações populares em língua espanhola, seus momentos e territórios, de forma a promover o reconhecimento do meio, a compreensão e convivência no relacionamento entre o local, o regional e o global.

Neste sentido, nossas ações continuarão voltadas para a promoção de outras sábias e criativas maneiras de viver, de sentir e de pensar a vida com a sabedoria e a sensibilidade das artes e das culturas não como fragmentos do que é pitoresco e curioso, mas como forma de 
pensar e construir a noção de alteridade, seus caminhos, desafios e possibilidades de forma a reconhecer o outro como parte de si, como valor socializador e humanizador relevante.

Dessa forma, a reflexão mediada pelo cinema, pelo diálogo, pelo intercâmbio e pela negociação de sentidos entre os envolvidos deve ser incentivada e praticada. Estamos diante da construção de um processo ativo, dinâmico, instável, possibilitador de possíveis ressignificações e reconstruções. Lançamos as sementes ao solo e regamos. Sabemos que as condições estão favoráveis a potencial (re)significação e (re)construão de crenças, que podem ocorrer de forma lenta e processual ao longo de futuras experiências e práticas, na medida do possível, mediadas pelo cinema.

Não podemos afirmar até que ponto as crenças de Lourdes Maria e Isabelly foram, realmente, (re)construídas e proporcionaram ou proporcionarão mudanças em suas ações, mas temos indícios e acreditamos que as atividades proporcionadas ao longo de 2013.2 contribuíram positivamente nesse sentido e possibilitaram às participantes ter novos olhares para os temas trabalhados. Elas se engajaram em um processo de reflexão e ressignificação de suas crenças. Essas participantes demonstraram maior prontidão conceitual para mudança, já Ana Cecília se mostrou mais resistente e impermeável ao conteúdo trabalhado o que não impede que sementes tenham sido plantadas em sua mente e germinem no futuro, já que a relação entre conscientização oportunizada por conceitos científicos e a transformação de conceitos cotidianos não é linear, do tipo estímulo-resposta.

Uma participante dotada reflexivamente de conceitos científicos pode até não mudar seus conceitos cotidianos relacionados à forma como aprende e ensina determinada língua estrangeira bem como o tratamento que dá à variação linguística experimentada pelo idioma, porém, terá condições de saber os motivos de agir da forma como age e de obter, como consequência, os resultados que obtém.

Dito de outra maneira, parafraseando Blatyta (1999), nossas participantes podem até optar por uma mesma solução já anteriormente adotada, escolher não mudar diante das alternativas e visões apresentadas, mas, a partir de uma compreensão crítica, suas decisões serão por opção e não por falta de alternativas. 


\section{CONSIDERAÇÕES FINAIS}


Iniciamos o texto desta tese com uma epígrafe que relata um pensamento de Paulo Freire que nos parece muito oportuno de ser retomado neste momento. Para o educador brasileiro, "quando o homem compreende a sua realidade, pode levantar hipóteses sobre o desafio dessa realidade e procurar soluções. Assim, pode transformá-la com seu trabalho (FREIRE, 1979, p. 30)".

Este pensamento traduz nossa busca nesta empreitada investigativa: a partir de nossa experiência como hispanista em construção, acumulada em nossa trajetória como estudante, professor e investigador em vários contextos e modalidades de ensino, diante do desafio de ensinar Espanhol-Língua Estrangeira e formar professores deste idioma no interior do estado da Paraíba, buscamos meios e ferramentas para compreender este contexto.

Conforme explicitado no capítulo 1 e, a partir das constatações observadas, dentre elas, que: i) $71 \%$ dos alunos do curso de Letras-Espanhol do campus VI da UEPB preferem o espanhol peninsular em detrimento do espanhol americano, ii) apenas $8 \%$ deles vê a língua espanhola como língua de integração, iii) 59\% deles gostariam de ser identificados, enquanto falantes, com espanhóis e, por estarmos localizados numa região que, assim como $90 \%$ das cidades brasileiras, não possui sala de cinema e, como consequência, iv) $60 \%$ deles nunca foi ao cinema e, v) apenas $16 \%$ declaram ir ao cinema ao menos uma vez por ano, vi) $42 \%$ deles declaram raramente assistir produtos audiovisuais, vii) a adoção da Espanha como principal sonho de destino turístico, viii) a ausência de uma cultura de apreciação do audiovisual, iv) a invisibilidade da América Latina e a não consciência desse território como uma construção cultural que ultrapasse nossas barreiras geográficas; fomos buscar na teoria apoio para a promoção, via cinema, de situações que propiciassem a reflexão do aprendiz enquanto professor em formação, buscando a (re)significação e (re)construção de crenças de forma a transformar nossa realidade e potencializar o desenvolvimento dos participantes envolvidos.

$\mathrm{Na}$ busca por caminhos, contamos com um embasamento teórico que nos proporcionasse a base para a pesquisa e nos permitisse traçar considerações posteriores. Neste sentido, ao longo do trajeto, tomamos consciência de que deveríamos nos dedicar a levar nossos participantes a compreender as principais teorias e modelos de aquisição/aprendizagem de línguas e algumas de suas representações cinematográficas, de forma que o cinema pudesse ser um mediador das reflexões em torno desta temática, conforme expusemos no capítulo 5. Demo-nos conta de que esta não é uma tarefa fácil e que, 
diante dos muitos modelos apresentados, devemos compreendê-los - na maioria das vezes como complementares e não excludentes.

Visando analisar as crenças de nossos alunos envolvidos em nossa prática diária como educador e, consequentemente, como participantes da nossa pesquisa e beneficiários dela, buscamos compreender as crenças como um dos elementos da cognição de professores, vista desde uma perspectiva sociocultural, de acordo com o que apresentamos no segundo capítulo. Constatamos que existe uma grande floresta terminológica que envolve a questão e, diante disso, apresentamos a definição de crença, cognição de professores de línguas, conceitos, zona de desenvolvimento proximal, mediação e internalização que comungamos no desenvolvimento desta tese.

Nossa trajetória foi toda acompanhada pelo uso do cinema, compreendido, a partir da teoria sociocultural, como artefato cultural que medeia situações de ensino-aprendizagem e funciona como dispositivo para o desenvolvimento reflexivo do aprendiz. Neste intuito, o quarto capítulo apresentou reflexões acerca da sétima arte e as possíveis contribuições do cinema para a compreensão e potencialização do processo de ensino-aprendizagem do espanhol como língua estrangeira. Observamos que o cinema, adotado numa perspectiva ampla como imagem em movimento, pode contribuir, pelo menos, de três formas com a educação: i) como recurso didático aliado ao processo de ensino-aprendizagem; ii) como corpus de pesquisa para a compreensão de como a cultura escolar é representada pelo cinema, isto é, como as funções, objetivos, práticas e agentes escolares são veiculados por essa mídia; iii) como dispositivo desencadeador de reflexões compartilhadas.

Dando continuidade à busca por um caminho que possibilitasse trabalhar nossas inquietações, constituímos um corpus com filmes que retratam situações de contatos linguísticos em contextos formais e informais de ensino-aprendizagem e que propiciassem um passeio pelo universo hispânico. A análise dos filmes com a temática do complexo processo de aquisição/aprendizagem foi apresentada no quinto capítulo e o material reunido foi utilizado nas atividades promovidas ao longo do semestre 2013.2 numa proposta que visou a tomada de consciência e a reflexão crítica dos envolvidos enquanto professores em formação. A experiência foi registrada com o auxílio de diversos instrumentos e a análise dos resultados foi apresentada no capítulo 6.

Nossas reflexões acerca da unidade e diversidade $n a$ e $d a$ língua espanhola numa perspectiva intercultural foram registradas no terceiro capítulo e, posteriormente, foram 
apresentadas aos nossos alunos, com a mediação de filmes com conteúdo linguístico e sóciopolítico-cultural relevantes com vistas a promover a formação do professor como mediador intercultural atento às discursividades que envolvem a língua espanhola enquanto idioma multidimensional.

Dessa forma, esta pesquisa partiu da nossa realidade como professor de E-LE e formador de professores e buscou meios para promover a transformação dos envolvidos neste contexto. Em outras palavras, diante da perspectiva freireana, nosso trajeto buscou compreender nossa realidade, levantar hipóteses e procurar soluções para transformá-la e, consequentemente, transformar a nós mesmos, em busca do aprimoramento constante.

Observamos tratar-se de um processo bastante complexo, ativo, dinâmico e instável. Nossas participantes apresentaram formas diferentes de perceber o mundo e de reagir às atividades propostas, num conflito constante entre crenças arraigadas e as novas possibilidades mediadas pelo cinema. Cada uma delas reagiu de forma distinta aos estímulos para a inspeção, (re)significação e (re)construção de crenças nos colocando diante de um processo de evolução gradativa de expansão do olhar, da compreensão e do sentir.

Diante do exposto, nossa experiência reforçou a nossa tese de que o cinema pode contribuir significativamente para se trabalhar com a variação linguística e com a conscientização linguística acerca do aprendizado do espanhol língua-estrangeira com professores brasileiros em formação inicial por meio de filmes, considerados - conforme a perspectiva sociocultural que adotamos para este trabalho - como artefatos culturais, ferramentas de mediação simbólica potencializadoras do desenvolvimento humano.

O período de um semestre foi muito curto para que pudéssemos traçar observações conclusivas a respeito das possíveis transformações no sistema de crenças das nossas participantes. Dessa forma, o ideal é que futuros trabalhos envolvendo a (re)significação e (re)construção de crenças lancem mão de estudos longitudinais o bastante para que se percebam os possíveis movimentos no sistema de crenças numa relação dialógica entre discursos e ações em contextos situados e com a reflexão propiciada via mediação adequada.

A transformação de conceitos cotidianos à luz de conceitos científicos depende diretamente de conscientização teórica e reflexão mediada por artefatos e pessoas, em contextos e atividades significativas para os participantes de forma a promover o engajamento na negociação e coconstrução de sentidos. 
Além de estudos longitudinais, o ideal seria que pesquisas semelhantes fossem desenvolvidas em outros contextos para que pudéssemos mapear a reação dos diversos participantes de forma a desenvolvermos subsídios para trabalhos de formação inicial e continuada de professores de E-LE utilizando o cinema como ferramenta potencializadora do desenvolvimento humano.

Apesar das limitações que apontamos, julgamos a experiência como positiva para todos os participantes, incluindo o pesquisador, pois proporcionou subsídios para o aprimoramento do nosso trabalho como professor de E-LE e formador de professores de línguas, bem como para o curso de Letras-espanhol do campus VI da UEPB, que poderá contar com os resultados obtidos para pensar o processo de reformulação curricular, bem como para direcionar nossas ações no ensino, pesquisa e extensão, de forma a promover a conscientização linguística acerca dos comportamentos, hábitos e atitudes que influenciam na forma como se estuda e se aprende a língua estrangeira, com vistas a fomentar a autonomia e a autoaprendizagem, contribuindo assim para a redução das taxas de reprovação e de evasão no campus. 


\section{REFERÊNCIAS}


E como se confecciona uma bibliografia? Ela é um catálogo dos textos lidos pelo autor enquanto o projeto atual de escrita o conduz, logo, necessariamente limitada e incompleta. Até onde ir na recessão de suas leituras? Deve-se acrescentar os jornais, os romances policiais? Como distinguir aquilo que foi útil, aquilo que surgiu ao acaso? E por que não os filmes? E as conversas? E as velhas leituras, as da infância, que me fazem ainda sonhar? Uma bibliografia verídica, sincera e exaustiva é tão impossível quanto uma confissão verdadeira (COMPAGNON, 1996, p. 113). 
ACADEMIA ARGENTINA DE LETRAS. Diccionario del habla de los argentinos. Buenos Aires: Espasa, 2004.

ADAMSON, A. \& JENSON, V. (Dir.) Shrek. DVD: EUA, 2001.

AGUILERA REIJA, B. et al. Educación Intercultural: análisis y resolución de conflictos. Madrid: Editorial Popular, 1996.

ALLWRIGHT, D. \& BAILEY, K. M. Focus on the Language Classroom: an introduction to classroom, research for language teachers. Cambridge: Cambridge University Press, 1991.

ALMEIDA FILHO, J.C.P. Dimensões comunicativas no ensino de línguas. Campinas: Pontes, 1993.

ALMEIDA FILHO, J.C.P. Lingüística Aplicada, Ensino de Línguas \& Comunicação. Campinas: Pontes Editores e ArteLíngua, 2005.

ALMEIDA, M.J. A linguagem na nova oralidade: imagens e sons In: Coletânea Lições com cinema. São Paulo: FDE, 1994, p. 117-124.

ALVES, G. "O cinema como experiência crítica: tarefa política do novo cineclubismo no século XXI”. In: ALVES, G.; MACEDO, F. Cineclube, cinema \& educação. (Orgs.) Londrina: Praxis, Bauru: Canal 6, 2010.

ANDIÓN HERRERO, M. A. Variedades del español de América: una lengua y diecinueve países. Brasília: Embajada de España. Consejería de Educación, 2004.

ANDRADE, J.B. Cineclube, Cinema e Educação. In: ALVES, G.; MACEDO, F. (Orgs). Cineclube, cinema \& educação. Londrina/Bauru: Praxis/Canal 6, 2010.

ANDRÉ, M.E.D.A. Etnografia da Prática Escolar. Editora Papirus, 1995.

ARAÚJO, D. R. Crenças de professores de inglês de escolas públicas sobre o papel do bom aprendiz: um estudo de caso. 2004. Dissertação (Mestrado em Estudos Linguísticos) . Faculdade de Letras, UFMG, Belo Horizonte, 2004.

ARNOUX, E. N. "El conocimiento del otro en el proceso de integración regional. Propuestas para la enseñanza media". En DA HORA, Dermeval y Rubens MARQUES DE LUCENA (orgs.): Política lingüística na América Latina, João Pessoa, Idéia/Editora Universitária, 2008.

ARNOUX, E. N. Lo lingüístico es fundamental para la integración regional. Entrevista concedida as repórteres Natalia Aruguete e Bárbara Schijman, publicada no jornal Página 12. Buenos Aires, 10 de Setembro de 2012. Disponível em: $<$ http://www.pagina12.com.ar/diario/dialogos/21-203013-2012-09-10.html>. Acesso em: 29 set. 2012. 
ARNOUX, E. N. Representaciones sociolingüísticas y construcción de identidades colectivas en el Mercosur. In: CELADA, M.T. et al. Lenguas en un espacio de integración: acontecimientos, acciones, representaciones. Buenos Aires: Biblos, 2010.

BAKHTIN, M. Estética de la creación verbal. Traducción de Tatiana Bulbnova. Madrid: Siglo XXI, 1999.

BAKHTIN, M. O freudismo. São Paulo: Perspectiva, 2007.

BARCELOS, A. M. F. A cultura de aprender língua estrangeira (inglês) de alunos de Letras. Dissertação (Mestrado em Linguística Aplicada). IEL/UNICAMP, 1995.

BARCELOS, A. M. F. A cultura de aprender línguas (inglês) de alunos no curso de Letras. In: ALMEIDA FILHO, J.C.P. (Org.) O professor de língua estrangeira em formação. Campinas: Pontes, 1999.

BARCELOS, A. M. F. Metodologia de Pesquisa das Crenças sobre Aprendizagem de Línguas: Estudo da Arte. Rev. Brasileira de Lingüística Aplicada, v.1, n.1, p.71-92, 2001.

BARCELOS, A. M. F. Reflexões acerca da mudança de crenças sobre ensino e aprendizagem de línguas. Rev. Brasileira de Lingüística Aplicada, v. 7, n. 2, 2007.

BARCELOS, A. M. F.. Cognição de professores e alunos: tendências recentes na pesquisa de crenças sobre ensino e aprendizagem de línguas. In: Barcelos, A. M. F. e VIEIRAABRAHÃO, M. H. (Orgs.) Crenças e ensino de línguas: foco no professor, no aluno e na formação de professores. Campinas: Pontes, 2006, p. 15-42.

BARCELOS, A. M. F.. Prefácio. In: ZOLIN-VESZ, F. Crenças sobre ensinar e aprender espanhol: reprodução e manutenção do status quo e da estratificação social. Campinas: Pontes, 2013c.

BARCELOS, A. M.F.; KAJALA, P. (eds.) Beliefs about SLA: New Research Approaches. Dodretch: Kluwer, 2003.

BARCELOS, A. M.F.; KAJALA, P. Beliefs in Second Language Acquisition: Learner. In: CHAPELLE, C. A. (ed.) The Encyclopedia of Applied Linguistics. Malden: Wiley-Blackwell, $2013 \mathrm{a}$.

BARCELOS, A. M.F.; KAJALA, P. Beliefs in Second Language Acquisition: Teacher. In: CHAPELLE, C. A. (ed.) The Encyclopedia of Applied Linguistics. Malden: Wiley-Blackwell,, $2013 b$.

BARCELOS, A.M.F. Explorando crenças sobre ensino e aprendizagem de línguas em material didático In: SCHEYERL, D. e SIQUEIRA, S. (Orgs.) Materiais didáticos para o ensino de línguas na contemporaneidade: contestações e proposições. Salvador: EDUFBA, 2012. p. 109-133. 
BARRO, A.; JORDAN, S.; ROBERTS, C. La práctica cultural en la vida cotidiana: el estudiante de idiomas como etnógrafo. In: BYRAM, M. \& FLEMING, M. (Org.) Perspectivas interculturales en el aprendizaje de idiomas: enfoques a través del teatro y la etnografía. Madrid: Cambridge University Press, 2001.

BEDRAN, P. F. A (re)construção das crenças do par interagente e dos professores mediadores no Teletandem. Dissertação (Mestrado em Estudos Linguísticos). São José do Rio: UNESP, 2008.

BEIN, R. Los idiomas del MERCOSUR. Revista Todavía - maio de 2008. Disponível em: $<$ http://www.revistatodavia.com.ar/notas/bein/frame_bein1.htm>. Acesso em: 01 out. 2012.

BHABHA, H. K. O local da cultura. Belo Horizonte: UFMG, 1998.

BLATYTA, D. F. Mudança de habitus e teorias implícitas: uma relação dialógica no processo de educação continuada de professores. In: ALMEIDA FILHO, J. C. P. (Org.). O professor de língua estrangeira em formação. Campinas: Pontes, 1999. p. 63-81.

BLOCK, D. The social turn in second language acquisition. Washington: Georgetown University Press, 2003.

BORENSZTEIN, Sebastián (Dir.) Un Cuento Chino (Um conto chinês). DVD, Argentina: 2011.

BORG, S. (2009). Introducing language teacher cognition. Disponível em: $<$ http://www.education.leeds.ac.uk/research/files/145.pdf>. Acesso em: 18 fev. 2013.

BORG, S. Teacher cognition and language education. London, UK: Continuum, 2006.

BRASIL. Presidência da República. Lei $n^{\circ} 11.161$, de 5 de Agosto de 2005: Dispõe sobre o ensino da língua espanhola. Disponível em: $<$ https://www.planalto.gov.br/ccivil_03/_Ato2004-2006/2005/Lei/L11161.htm>. Acesso em: 10 out. 2012.

BRASIL. Secretaria de Educação Básica. Orientações Curriculares para o Ensino Médio: Linguagens, códigos e suas tecnologias - Conhecimentos de Espanhol. Brasília: Ministério de Educação, 2006, p.127-164.

BRASIL. Secretaria de Educação Fundamental. Parâmetros curriculares nacionais: terceiro e quarto ciclos do ensino fundamental: língua estrangeira. Brasília: MEC/SEF, 1998. 120 p.

BRIZ, A. Cuadernos de Lengua Española - El español coloquial: situación y uso. Madrid: Arco Libros, 1998.

BROOK, P. O Ponto de Mudança. Rio de Janeiro: Civilização Brasileira, 1995.

BROOKS, James L. (Dir.) Spanglish (Espanglês). DVD, EUA: 2004. 
BRUNO, F.A.T.C. \& MENDOZA, M.A.C.L. Hacia el español: Curso de lengua y cultura hispánica. Nivel Avanzado. São Paulo: Saraiva, 2001.

BRZEZINSKI, I. (Org.). Profissão professor: identidade e profisssionalização docente. Brasília: Plano Editora, 2002.

BUGEL, T. O Espanhol na cidade de São Paulo: quem ensina qual variante a quem? Dissertação de Mestrado em Lingüística Aplicada, Campinas: IEL/Unicamp, 1998.

BUSNARDO, J. Contextos pedagógicos e conceitos de cultura no ensino de línguas estrangeiras. In: SANTOS, P.; ALVAREZ, M.L.O. (Orgs.). Língua e cultura no contexto de português língua estrangeira. Campinas: Pontes, 2010. p. 123-139.

BYRAM, M. Teaching and Assessing Intercultural Communicative Competence. Clevedon: Multilingual Matters, 1997.

CALVET, L.J. Lingüistica y colonialismo. Tradução: Luciano Padilla López. Buenos Aires: Fondo de Cultura Económica, 2005. [Original: Linguistique et colonialisme. Petite Bibliothèque Payot. Paris, 2002]

CALVET, L.J. As políticas lingüísticas. Tradução: Isabel de Oliveira Duarte, Jonas Tenfen e Marcos Bagno. São Paulo: Parábola Editorial/IPOL, 2007. [Original: Les politiques linguistiques. Paris, P.U.F, 1996]

CALVET, L.J. Sociolingüistica: uma introdução crítica. Tradução: Marcos Marcionilo. São Paulo: Parábola, 2002. [Original: La sociolinguistique. Paris: P.U.F. 1993]

CAMPANELlA, Juan José (Dir.) El hijo de la novia (O filho da noiva). DVD, Argentina, 2001.

CANALE, M.; SWAIN, M. "Theoretical bases of communicative approaches to second language teaching and testing" In: Applied Linguistics, 1980, vol. 1, n. ${ }^{\circ} 2$.

CANÇADO, M. Procedimentos de Pesquisa Etnográfica em Sala de Aula de Língua Estrangeira: Avaliação das Potencialidades e Limitações da Metodologia. Dissertação (Mestrado em Estudos Linguísticos). Belo Horizonte: UFMG, 1991.

CÂNDIDO, A. O direito à literatura. In: CÂNDIDO, A. Vários escritos. São Paulo: Duas cidades, 1995. P. 235-63.

CAÑAS, R.S. Formação linguística para estudantes brasileiros de espanhol como língua estrangeira em contexto universitário. Projeto RETIDE. Monteiro: CCHE/UEPB, 2012.

CARDOSO, R.C.T. O imaginário do comunicativismo entre professores de língua estrangeira/inglês (e sua confrontação com teoria externa). Tese (Doutorado em Letras Filologia e Linguística Portuguesa). Assis: UNESP, 2002. 
CAVALCANTI, M. C. Reflexões sobre a prática como fonte de temas para projetos de pesquisa para a formação de professores de LE. In: ALMEIDA FILHO, J.C.P. (Org.) $O$ professor de língua estrangeira em formação. Campinas: Pontes, 1999. P. 179-184.

CELADA, M.T. \& RODRIGUES, F.S.C. El español en Brasil: actualidad y memoria. Real Instituto Elcano de Estudios Internacionales y Estratégicos, España, 2005.

CELADA, M.T. Espanhol para brasileiros: uma língua singularmente estrangeira. 275 f., Tese (Doutorado). IEL/UNICAMP, 2002.

CENTRO VIRTUAL CERVANTES. Diccionario de términos clave de ELE, 2014. Disponível em: <http://cvc.cervantes.es/ensenanza/biblioteca_ele/diccio_ele/diccionario/>. Acesso em: 17 abr. 2014.

CHAREILLE, S. Planificación lingüística y constitución de un bloque regional: el caso del Mercosur (Argentina, Brasil, Paraguay y Uruguay) y de Chile. In: Language Problems \& Language Planning, v27, n1, 2003, pp 63-70.

COLE, M. Cultural Psychology: a once and future discipline. Cambridge, MA: The Bellnap Press of Harvard University Press, 1996.

COMPAGNON, A. O trabalho da citação. Belo Horizonte: UFMG, 1996.

CONCEIÇÃO PINTO, C. F. Considerações sobre a origem e a caracterização do Espanhol americano. Língua \& Educação, v. 1, p. 39-48, 2009.

CONNELLY, M.F. \& CLANDININ, D.J. Stories of experience and narrative inquiry. Educacional Researcher, (1990) 19(5).

CRUZ, M.L.O.B. Etapas de interlengua oral en estudiantes brasileños de español. Colección Monografías ASELE, n. ${ }^{\circ}$ 6. Málaga, 2004.

CUARÓN, Alfonso (Dir.) Y tu mamá también. (E sua mãe também) DVD, México, 2001.

D’OLIM MAROTE, J.T. (Org.) Minidicionário: Francês/Português, Português/Francês. São Paulo: Ática, 2002.

DENZIN, N. K. The many faces of emotionality. In: ELLIS, C.; FLAHERTY, M. G. (Eds.). Investigating subjectivity. Newbury Park, CA: Sage Publications, 1992.

DI CAMARGO, I. ; TOLEDO E.L.S. A riqueza polifônica determinando os sentidos de "Jesus de Montreal", de Denys Arcand.. In: TOLEDO E.L.S.; SANT'ANA SPERA, J.M.. (Org.). Lingüistica Textual: Literatura, Relações Textuais, Ensino.. 1 ed. São Paulo: Editora Arte \& Ciência, 2007, v. 01, p. 103-112.

DI CAMARGO, I.J. A Memória de Futuro analisada pela Linguagem Cinematográfica: Diálogos entre a Teoria do Cinema e Mikhail Bakhtin. Dissertação (Mestrado em Linguística). São Carlos: UFSCar, 2009. 
DIAMOND, C. T. P.; MULLEN, C. A. The postmodern educator: arts-based inquiries and teacher development. New York: Peter Lang, 1999.

DUFVA, H. Beliefs in Dialogue: a Bakhtinian view. In: KAJALA, P; BARCELOS, A. M. F. (eds.). Beliefs about SLA: New Research Approaches. Dodrecht: Kluwer, 2003.

EISNER, E. W. "The promise and perils of alternative forms of data representation". Educational Researcher, v. 26, n. 6, p. 4-10, 1997.

EISNER, E. W. The enlightened eye. New York: Macmillan Publishing Company, 1991.

ERES FERNÁNDEZ, I.G.M. "Linguística contrastiva e ensino/aprendizagem de línguas estrangeiras na atualidade: algumas relações" In: Estudos da Linguagem. Universidade Estadual de Londrina. Londrina. 2003. N. ${ }^{\circ}$ 6/2. Pp.: 101-118.

ERICKSON, F. Qualitative methods in research on teaching. In: WITTROK, M.C. (Ed.) Handbook of research on teaching. New York: Macmillan, 1986.

FABRIS, E.T.H. Em cartaz: o cinema brasileiro produzindo sentidos sobre escola e trabalho docente. Tese (doutorado em educação). Porto Alegre: UFRGS, 2005.

FANJUL, A. P. Português brasileiro, espanhol de... onde? Analogias incertas. Letras \& Letras, Uberlândia 20 (1) 165-183, jan./jun., 2004.

FERGUSON, C. Diglosia, In: GARVIN, P. y LASTRA, Y. (eds.). Antología de etnolingüística y sociolingüística. México: UNAM, 1984.

FILHO, A. G. 'Destino São Paulo' acerta ao tratar dos imigrantes. 'Dia da Independência' é o episódio de estreia da série da HBO. O Estado de S. Paulo, 25 de novembro de 2012. Disponível em: <http://www.estadao.com.br/noticias/impresso,destino-sao-paulo-acerta-aotratar-dos-imigrantes, 964876,0.htm>. Acesso em: 19 abr. 2014.

FISHMAN, J. Sociología del lenguaje. Madrid: Cátedra, 1979.

FLEURI, R. M. Intercultura e educação. Educação, Sociedade \& Culturas. Porto, Portugal, v. 23, 2005.

FREIRE, P. Educação e Mudança. Rio de Janeiro: Paz e Terra, 1979.

FREIRE, Paulo. A educação na cidade. Rio de Janeiro: Paz e Terra, 1991.

FREIRE, P. Pedagogia da autonomia: saberes necessários à prática educativa. São Paulo: Paz e Terra, 1996.

GABASSI, Alex (Dir.) “Dia da Independência”, episódio da Série Destino: São Paulo HBO Brasil, 2012. 
GARCIA DE STEFANI, V. C. Aprendendo a ensinar com filmes: o cinema como recurso didático para uma abordagem intercultural. Tese em andamento (Doutorado em Linguística). São Carlos: UFSCar, 2014.

GARCIA DE STEFANI, V. C. O cinema na aula de lingua estrangeira: uma proposta didático-pedagógica para o ensino-aprendizagem de espanhol. Dissertação (Mestrado em Linguística). São Carlos:UFSCar, 2010.

GEHLEN, S. T.; DELIZOICOV, D. A dimensão epistemológica da noção de problema na obra de Vigotski: implicações no ensino de ciências. Investigações em Ensino de Ciências. v.17, n.1, p. 59-79, 2012.

GIMENEZ, T. Learners becoming teacher: an exploratory study of beliefs held by prospective and practicing EFL teachers in Brazil. Tese (Doutorado em Linguistics and Modern English Language). Lancaster: Lancaster University, 1994.

GOETTENAUER, E. Espanhol: língua de encontros. In: SEDYCIAS, J. (Org.). O ensino do espanhol no Brasil. São Paulo: Parábola Editorial, 2005, p. 61-70.

GÓMEZ ALIBÉS, J. Una nueva visión en la presentación de situaciones cotidianas en el aula de E/LE: uso de fragmentos de películas en sustitución de las tradicionales grabaciones de audio. Memoria de Máster en Enseñanza de Español Lengua Extranjera (MEELE). Madrid: Universidad Antonio de Nebrija, 2008.

GONZÁLEZ, N. T. M. "Lugares de interpretação do fenômeno de aquisição de línguas estrangeiras". Estudos Lingüísticos, Campinas, 2004.

GONZÁLEZ, R. (Coord.) Cine latinoamericano y nuevas tecnologías audiovisuales. La Habana: Observatorio del Cine y el Audiovisual Latinoamericano, Fundación del Nuevo Cine Latinoamericano, 2011.

GOODWIN, C.; DURANTI, A. Rethinking context: an introduction. In: GOODWIN, C.; DURANTI, A. (Eds.) Rethinking context: language as an interactive phenomenon. Cambridge: CUP, 1992.

GUTIÉRREZ ALEA, Tomás; TABÍO, Juan Carlos (Dir.) Fresa y Chocolate (Morango e Chocolate). DVD, Cuba: 1993.

HALL, G. Exploring English Language Teaching: Language in Action. New York: Routledge, 2011.

HEY, A. P.; CATANI, A. M. Bourdieu e a educação. Cult (São Paulo), v. 11, p. 62-64, 2008.

HOSENFELD, C. Evidence of emergente beliefs of a second language learner: a diary study. In: BARCELOS, A. M.F.; KAJALA, P. (eds.) Beliefs about SLA: New Research Approaches. Dodretch: Kluwer, 2003. 
HOYOS-ANDRADE, R. Dialectología americana y enseñanza del español. In: Língua e Literatura, FFLCH / USP, São Paulo, 3.v. p. 171-181, 1974.

HYMES, D. "On communicative competence" (extracts). In: Brumfit, C.J. e K. Johnson (Orgs.) The Communicative approach to language teaching. Oxford: Oxford University Press., 1979.

JIN, L. \& CORTAZZI, M. La cultura que aporta el alumno: ¿puente u obstáculo? In: BYRAM, M. \& FLEMING, M. (Org.) Perspectivas interculturales en el aprendizaje de idiomas:enfoques a través del teatro y la etnografía. Madrid: Cambridge University Press, 2001.

JOHNSON, K. Second Language Teacher Education: A sociocultural perspective. New York: Routledge, 2009.

JOHN-STEINER, V. Notebooks of the mind: Explorations of thinking. New York: Oxford University Press, 1997.

KFOURI-KANEOYA, M.L.C. A formação inicial de professoras de linguas paralem contexto mediado pelo computador (teletandem): um diálogo entre crenças, discurso e reflexão profissional. Tese (Doutorado em Estudos Linguísticos). São José do Rio Preto: UNESP, 2008.

KLAPISCH, C. (Dir.) L'Auberge espagnole (Albergue Espanhol). DVD, Espanha/França: 2003.

KOZULIN, A. Psychologycal Tools: a sociocultural approach to education. Cambridge, MA: Harvard University Press, 1998.

KRAMSCH, C. El privilegio del hablante intercultural. In: BYRAM, M. \& FLEMING, M. (Org.) Perspectivas interculturales en el aprendizaje de idiomas: enfoques a través del teatro y la etnografía. Madrid: Cambridge University Press, 2001.

KRAMSCH, C. Metaphor and the subjective construction of beliefs. In: KALAJA, P. \& BARCELOS, A.M.F. (Orgs.) Beliefs about SLA: new research approaches. Dordrecht: Kluwer, 2003.

KRASHEN, S.D. Principles and practice in second language acquisition. N.Y.: Pergamon Press, 1982.

KRASHEN, S. D. The Input Hypothesis: issues and implications. London: Longman, 1985.

KUDIESS, E. As crenças e o sistema de crenças do professor de inglês sobre o ensino e a aprendizagem da língua estrangeira no sul do Brasil: sistema, origens e mudanças. Linguagem e Ensino, Pelotas, v. 8, n. 2, p. 39-96, 2005.

KUMARAVADIVELU, B. Language Teacher Education for a Global Society: a modular model for knowing, analyzing, recognizing, doing and seeing. New York: Routledge, 2012. 
LANTOLF, J.P. Sociocultural Theory and Second Language Acquisition. Oxford: Oxford University Press, 2000.

LANTOLF, J.P. Sociocultural theory and second language learning: state of art. Studies in Second Language Acquisition, 28, p. 67-109, 2006.

LANTOLF, J.P. \& THORNE, S.L. Sociocultural theory and the genesis of second language development. Oxford: OUP, 2006.

LAPLANTINE, F. Aprender antropologia. São Paulo, Brasiliense, 2000.

LARSEN-FREEMAN, D. \& CAMERON, L. Complex Systems and Applied Linguistics, Oxford: Oxford University Press, 2008.

LARSEN-FREEMAN, D. \& LONG, M.H. Introducción al estudio de la adquisición de segundas lenguas. Tradução de Isabel Molina Martos e Pedro Benítez Pérez. Madrid: Gredos, 1994.

LAS LENGUAS. I Congreso: por el reconocimiento de uma Iberoamética pluricultural e multilingüe, 1., 2004, Rosario (Argentina). Actas... Rosário: Editorial Último Recurso, 2007.

LASECA, A. La enseñanza del español en el sistema educativo brasileño. Brasília: Embajada de España-Consejería de Educación, 2008.

LEFFA, V. J. . Quando menos é mais: a autonomia na aprendizagem de línguas. In: Christine Nicolaides; Isabella Mozzillo; Lia Pachalski; Maristela Machado; Vera Fernandes. (Org.). $O$ desenvolvimento da autonomia no ambiente de aprendizagem de línguas estrangeiras. Pelotas: UFPEL, 2003, v. 1, p. 33-49.

LEMOS, M. A. O Espanhol em redes de memória. Antigas rotinas e novos sentidos dessa língua no Brasil. Dissertação de mestrado (Língua Espanhola e Literaturas Espanhola e Hispano-americana). São Paulo: USP, 2008.

LEONTEV, A.N. The problem of activity in psychology. In: Wertsch, J. (ed.).The concept of activity in Soviet Psychology. Aromnk, NY: M.E.Sharpe, inc., 1981. p. 37-71.

LOPE BLANCH, J.M. Estudios de lingüistica hispanoamericana. México: UNAM, 1989.

LOPES, F. R. Cinema: do Entretenimento à Prática Social. In: III Simpósio Nacional ABCiber, 2009, São Paulo. Anais do III Simpósio Nacional ABCiber. São Paulo: Editora ESPM, 2009.

LÜDKE, M.; ANDRÉ, M. E. D. A. Pesquisa em educação: abordagens qualitativas. São Paulo: EPU, 1986.

LURIA, A.R. Language and Cognition. New York: Johm Wiley \& Sons, 1982. 
MACEDO, F. Cineclube e autoformação do Público. In: ALVES, G.; MACEDO, F. (Orgs). Cineclube, cinema \& educação. Londrina/Bauru: Praxis/Canal 6, 2010.

MACEDO, F. Manual do cineclube. São Paulo, 2005.

MACHADO, L. M. Considerações sobre a natureza do trabalho científico. In: MACHADO, L. M.; MAIA, G. Z. A.; LABEGALINI, A. C. F. (Orgs.) Pesquisa em educação: passo a passo. Marília: Edições M3T, 2007, p. 1-14.

MANEGLIA, Juan Carlos; SCHEMBORI, Tana (Dir.) 7 cajas. DVD, Paraguai, 2012.

MARCHAND, P. (Dir.) Era uma vez o cinema. São Paulo: Melhoramentos, 1995

MARCUSCHI, L.A. Da fala para a escrita: atividades de retextualização. São Paulo: Cortez, 2004.

MARCUSCHI, L.A. Gêneros textuais: definição e funcionalidade. In: DIONISIO, A.P.; MACHADO, A.R.; BEZERRA, M.A. (Orgs.) Gêneros textuais e ensino. Rio de Janeiro: Lucerna, 2008.

MAYRINK, M.F. Luzes... câmera... reflexão: formação inicial de professores mediada por filmes. Tese (doutorado em Linguística Aplicada e Estudos da Linguagem). São Paulo: PUC, 2007.

MCCARTHY, Thomas (Dir.) The visitor (O Visitante). DVD, EUA, 2007.

MITCHELL, R. \& MYLES, Second Language Learning Theories. London: Arnold, 1998.

ORTEGA, L. Understanding Second Language Acquisition. London: Hodder Education, 2009.

MOITA LOPES, L.P. Da aplicação de Linguística à Linguística Aplicada Indisciplinar. In: PEREIRA, R. C.; ROCA, P. (Orgs.). Linguística aplicada: um caminho com diferentes acessos. São Paulo: Contexto, 2009. p. 11-24.

MOITA LOPES, L.P. Oficina de Lingüistica Aplicada: a natureza social e educacional dos processos de ensino/aprendizagem de línguas. Campinas: Mercado das Letras, 1996.

MORAES BEZERRA, I.C.R. Aquisição de Segunda Língua: de uma perspectiva lingüística a uma perspectiva social. SOLETRAS (UERJ), São Gonçalo - RJ, v. 05/06, p. 31-52, 2003.

MORAES, A. C. A escola vista pelo cinema: uma proposta de pesquisa. In: SETTON, M. G. J. (Org.). A cultura da mídia na escola: ensaios sobre cinema e educação. 1 ed. São Paulo: Annablume/USP, 2004, v. 1, p. 53-66.

MORAN, J.M. O vídeo na sala de aula. Comunicação \& Educação. São Paulo: ECA/Ed. Moderna. Jan./abr. 1995, n. 2, pp. 27-35. 
MORAN, J.M. Os vários usos do cinema e de vídeo na escola In: NAPOLITANO, M. Como usar o cinema na sala de aula. São Paulo: Contexto, 2003.

MORENO FERNÁNDEZ, F. "El modelo de la lengua y la variación lingüística" In: SÁNCHEZ LOBATO, J., SANTOS GARGALLO, I. (orgs.). Vademécum para la formación de profesores: enseñar español como segunda lengua / lengua extranjera. Madrid: SGEL, 2005, p. 737-752.

MORENO FERNÁNDEZ, F. Aportes de la sociolingüística a la enseñanza de lenguas. In: Principios de sociolingüística y sociología del lenguaje. Barcelona: Ariel, 1998.

MORENO FERNÁNDEZ, F. El español en Brasil. In: SEDYCIAS, J. (Org.) O ensino do espanhol no Brasil: passado, presente, futuro. São Paulo: Parábola Editorial, 2005

MORENO FERNÁNDEZ, F. Qué español enseñar. Madrid: Arco/Libros S.L., 2007.

MORENO GARCÍA, Concha. "Normas para ser ric@ y seguir comunicándose”. Actas del XI Congreso Internacional de ASELE. "Norma y variación en la enseñanza de ELE. ¿Qué español enseñar?”. 13 - 16 de septiembre. Zaragoza, 2000. Pp. 527 - 539.

NAPOLITANO, M. Como usar o cinema na sala de aula. São Paulo: Contexto, 2003.

OLIVEIRA, M. K. Pensar a educação; contribuições de Vygotsky. In: CASTORINA, J. A., FERREIRO, E., OLIVEIRA, M. K.de e LERNER, D. Piaget-Vygotsky: novas contribuições para o debate. São Paulo, Ática, 1995.

OLIVEIRA, M.K. "Vigotski e o processo de formação de conceitos". In: LA TAILLE, I. et al. Piaget, Vigotski e Walllon: teorias psicogenéticas em discussão. São Paulo: Summus, 1992.

PAIVA, V.L.M.O. "Modelo fractal de aquisição de línguas". In: BRUNO, F. C. (org.). Ensino-aprendizagem de línguas estrangeiras: reflexão e prática. São Carlos: Claraluz, 2005. Pp.: 23-36.

PAIVA, V.L.M.O. Aquisição em memórias de falantes e de aprendizes de línguas estrangeiras. Disponível em: <http://www.veramenezes.com/amfale2.htm>. Acesso em: 20 abr. 2012.

PAIVA. V.L.M.O. A complexidade da aquisição de segunda língua: revisando e conciliando teorias (em processo de produção), 2013.

PAIVA. V.L.M.O. Como o sujeito vê a aquisição de segunda língua. In: Arnaldo Cortina, Sílvia Naria Gomes da Conceição Nasser. (Org.). Sujeito e linguagem. Série Trilhas Linguísticas. 17ed.: , 2009, v. , p. 29-46.

PAJARES, M. F. Teacher's beliefs and educational research: cleaning up a messy construct. Review of educational research, v.62, n.3, 1992, p. 307-332. 
PAJARES, M. F.. Self-efficacy beliefs in academic settings. Review of educational research, v. 66, n.4, 1996, p. 543-578.

PASCUA VÍLCHEZ, F. Lengua, sociedad y cine: reflexiones sobre el bilingüismo en Paraguay, a través de la película 7 cajas, de Juan Carlos Maneglia y Tana Schémbori. Revista Sures, v. 3, p. 1-20, 2014.

PESSOA, R. P. \& SEBBA, M. A. Y. Mudança nas teorias pessoais e na prática pedagógica de uma professora de inglês. In: KALAJA; P; BARCELOS. A. M. F. (Ed.). Crenças e ensino de línguas: foco no professor, no aluno e na formação de professores. Campinas: Pontes, 2006. p. 43-64.

PINHEIRO, S.R.L. Educação, memória e cinema: um estudo comparativo das representações sociais da escola em "Os incompreendidos" e em "Machuca". Dissertação (mestrado em educação). São Paulo: USP, 2010.

PINILLA GÓMEZ, R. "La expresión oral” In: SÁNCHEZ LOBATO, J., SANTOS GARGALLO, I. (orgs.). Vademécum para la formación de profesores: enseñar español como segunda lengua / lengua extranjera. Madrid: SGEL, 2005, p. 879-897.

POSNER, G.. J.; STRIKE, K. A.; HEWSON, P. W.; GERZOG, W. A. Accomodation of a scientific conception: Toward a theory of conceptual change. Science Education, v. 66, n. 2, p. 211-227, 1982.

POZO, J. I. Teorias cognitivas da aprendizagem. Tradução de Juan Acuña Llorens. Porto Alegre: Artes Médicas, 1998.

REGO, T.C. Vigotski: uma perspectiva histórico-cultural da educação. Petrópolis: Vozes, 2000 .

REVUZ, C. "A língua estrangeira entre o desejo de um outro lugar e o risco do exílio". In: SIGNORINI, Inês (Org.) Lingua(gem) e identidade: elementos para uma discussão no campo aplicado. Campinas: Mercado das Letras; São Paulo: Fapesp, 1998, p. 213-230.

RODRIGUES, F. S. C. Língua viva, letra morta: obrigatoriedade e ensino de espanhol no arquivo jurídico e legislativo brasileiro. Tese (Doutorado em Letras: Língua Espanhola e Lit. Espanhola e Hispano-Americana). São Paulo: USP, 2010.

ROKEACH, M. Beliefs, attitudes, and values: A theory of organization and change. San Francisco: Jossey-Bass, 1968.

RONA, P. J. "El problema de la división del español americano en zona dialectales" In: Presente y Futuro de la Lengua Española. Madrid, 1964, Vol. I. pp.: 215-226

ROSA, M.V.F.P.C. \& ARNOLDI, M.A.G.A. A entrevista na pesquisa qualitativa. Belo Horizonte: Autêntica, 2009. 
SALLES, Walter (Dir.) The Motorcycle Diaries (Diários de motocicleta). DVD, Argentina, 2004.

SALOMÃO, A.C.B. A cultura e o ensino de língua estrangeira: perspectivas para a formação continuada no projeto Teletandem Brasil. Tese (Doutorado em Estudos Linguísticos). São José do Rio Preto: UNESP, 2012.

SALVADOR, A. C. (Org.). Español de cine: lo que hay que ver. Más de 250 películas imprescindibles de España e Hispanoamérica desde el inicio del sonoro hasta hoy, rodadas en español. Barcelona: Art Blume, 2009.

SANTOS, H. S. O papel de estereótipos e preconceitos na aprendizagem de línguas estrangeiras. In: Adrián P. Fanjul; Ana Cecilia Olmos; Mario M. González. (Org.). Hispanismo 2002. São Paulo: Associação Editorial Humanitas, Associação Brasileira de Hispanistas, 2004, v. vol. 1, p. 191-19

SPIELBERG, Steven (Dir.) The Terminal (O Terminal). DVD, EUA: 2004.

SCHUMANN, J.H. The acculturation model for second-language acquisition. In: GINGRAS, R. C. (Ed.) Second-language acquisition \& foreign language teaching. Washington: CAL, 1978.

SCHEIB, K. E. Historical and Conceptual Background. In: Beliefs and Values. USA: Holt, Rinehart and Winston, 1970.

SELINKER, L. “Interlanguage” In: IRAL, Vol. X/3, August, 1972.

SERRANI, S. M. A Formação do Professor e Currículo de Língua In: Discurso e Cultura na Aula de Língua: Currículo, Leitura, Escrita. Campinas: Editora Pontes, 2005. Pp. $13-58$.

SIGNORINI, I. Do residual ao múltiplo e ao complexo: o objeto da pesquisa em Lingüística Aplicada. In: SIGNORINI, I. \& CAVALCANTI, M. C., orgs. Lingüística Aplicada e transdisciplinaridade. Campinas: Mercado de Letras, 1998, p. 99-110.

SILVA, J. C. O cinema e os vínculos sociais. In: MONZANI, J.; LYRA, B. (Org.). Olhar Cinema.... São Carlos: Pedro e João Ed./ CECH - UFSCar, 2006. pp. 227-235.

SILVA, K. A. Crenças sobre o ensino e aprendizagem de línguas na Lingüística Aplicada: um panorama histórico dos estudos realizados no contexto brasileiro. Linguagem \& Ensino (UCPel. Impresso), v. 10, p. 235-271, 2007.

SILVA, K.A. "Crenças no ensino-aprendizagem e na formação de professores de línguas: pontos e contrapontos”. SILVA, K.A. (Org.) Crenças, Discursos e Linguagem - volume II. Campinas: Pontes Editores, 2011. 
SILVA, K.A. Crenças e aglomerados de crenças de alunos ingressantes em Letras (Inglês). Dissertação (Mestrado em Linguística Aplicada) - Instituto de Estudos da Linguagem, Unicamp, Campinas, 2005b.

SILVA, S.A. Bolivianos. A presença da cultura andina. São Paulo: Companhia Editora Nacional, 2005a.

SILVA, T.T. Documentos de identidade: uma introdução às teorias do currículo. Belo Horizonte: Autêntica, 2004.

SiMÃO, A. M. V., CAETANO, A. P., FLORES, M. A. Contextos e processos de mudança dos professores: uma proposta de modelo. Educação e Sociedade, v. 26, n. 90, p. 173-188, Jan./Abr. 2005. Disponível em: <http://www.cedes.unicamp.br>. Acesso em: 25 fev. 2014.

SOCA, R. Cocoliche: el habla mestiza de los inmigrantes italianos. Disponible en: $<$ http://www.elcastellano.org/ns/edicion/2004/septiembre/cocoliche.htm>. Acceso en: 16 mar. 2013 .

SOUZA, F.M Unidad, diversidad y la enseñanza del español americano para brasileños: el caso del español rioplatense. Hispanista (Edición Española), v. XIII, p. 1-12, 2012.

SOUZA, F.M. Espanhol-língua estrangeira para brasileiros. Políticas de difusão e formação de professores no estado de São Paulo. Dissertação (Mestrado em educação: políticas públicas e administração da educação brasileira). Marília: Faculdade de Ciências e Letras - UNESP, 2009.

SOUZA, F.M.; BONGESTAB, C. Texto fílmico: imagem e intertextualidade. In: SOUZA, F.M.; GHAZIRI, S.M. (Orgs.). Pesquisa e ensino de leitura no mundo atual: debates múltiplos. São Carlos: Pedro \& João Editores, 2012, v. 1, p. 18-37.

SOUZA, F.M.; CRUZ, M.L.O.B.; GAMA, A.P.F. "O cinema no aperfeiçoamento das competências do aprendiz de línguas (materna e estrangeira)". In: PINHO, S.Z.; SAGLIETTI; J.R.C. (orgs.) Núcleos de Ensino - Projetos de 2005. São Paulo: Cultura Acadêmica/UNESP Publicações, 2007. pp. 487-499.

SPIELBERG, S. [Dir.] The Terminal. DVD, Estados Unidos da América: 2004.

SWAIN, M., "Languaging, Agency and Collaboration in Advanced Second Language Learning," In: H. Byrnes, Ed., Advanced Language Learning: The Contributions of Halliday and Vygotsky, Continuum, London, 2006. pp. 95-108.

TELLES, J.A. “A trajetória narrativa: histórias sobre a formação do professor de línguas e sua prática pedagógica" In: Trabalhos em Lingüistica Aplicada, 34. Campinas: UNICAMP, 1999.

TELLES, J.A. Modos de representação: o espetáculo teatral como dispositivo de reflexão e representação do desenvolvimento do professor In: VIEIRA-ABRAHÃO, M.H. Prática de ensino de língua estrangeira: experiências e reflexões. Campinas: Pontes/Arte Língua, 2004. 
TELLES, J.A. Pesquisa educacional com base nas artes e reflexão compartilhada: por formas alternativas de representação da docência e do conhecimento dos professores. Tese (Livre-Docência)- Universidade Estadual Paulista, Faculdade de Ciências e Letras, 2005.

TELLES, J.A. Pesquisa educacional com base nas artes: pensando a educação dos professores como experiência estética. In: Educação e Pesquisa (USP), vol.32, n. ${ }^{\circ}$ 3, 2006, pp.509-530.

TERRIBILI, A. "Introdução às abordagens quantitativas". In: MACHADO, L. M. \& MAIA, G. Z. A. \& LABEGALINI, A. C. F. (Orgs.) Pesquisa em educação: passo a passo. Marília: Edições M3T, 2007.

TREVIZAN, Z. As malhas do texto: escola, literatura, cinema. São Paulo: Clíper, 1998.

TURNER, G. Cinema como prática social. São Paulo: Summus, 1997

VALLE, José del. La lengua, patria común: Política lingüística, política exterior y el postnacionalismo hispánico. In: WRIGHT, Roger; RICKETTS, Peter (Ed.). Studies on IberoRomance Linguistics Dedicated to Ralph Penny. Delaware: Juan de la Cuesta, 2005. p. 391415. Disponível em: <http://www.elcastellano.org/ns/edicion/2006/septiembre/delvalle.html>. Acesso em: 10 mar. 2013.

VAN MANEN, M. Investigación educativa y experiencia vivida. Barcelona: Idea Books, 2003.

VALLEJO, Henry (Dir.) El misterio del Kharisiri. DVD, Perú, 2004.

VARGAS LlOSA, M. Dicionário Amoroso da América Latina. (Tradução de Wladir Dupont \& Hortência Lancastre). Rio de Janeiro: Ediouro, 2006.

VENTURA, R. P. Variaciones en algunos usos pronominales del español. In: BRUNO, F. C. (Org.). Ensino-aprendizagem de línguas estrangeiras: reflexão e prática. São Carlos, SP: Claraluz, p. 115-120, 2005.

VERA, A.A. Metodologia da pesquisa cientifica. Porto Alegre: Globo, 1983.

VERTOV, D. O Homem da Câmera (Chelovek s Kinoapparatom) (1929). Disponível em: $U$ torrent Download.

VIEIRA-ABRAHÃO, M. H. A formação do professor de línguas estrangeiras de uma perspectiva sociocultural. Signum. Estudos de Linguagem, v. 15, p. 457-480, 2012.

VIEIRA-ABRAHÃO, M. H. Cognição de Professores de Línguas: Formação, Fatores Contextuais e Práticas de Sala de Aula. Contexturas, v. 16, p. 113-134, 2010.

VIEIRA-ABRAHÃO, M. H. Metodologia na investigação das crenças. In: BARCELOS, A.M.F.; VIEIRA-ABRAHÃO, M. H. (Orgs.) Crenças e ensino de línguas: foco no professor, no aluno e na formação de professores. Campinas: Pontes, 2006, p. 219-231. 
VIGOTSKI, L. S. A construção do pensamento e da linguagem. 2. ed., São Paulo: Martins Fontes, 2009.

VIGOTSKI, L.S. A formação social da mente: o desenvolvimento dos processos psicológicos superiores. Tradução: José Cipolla Neto et al. São Paulo: Martins Fontes, 2007.

VIGOTSKI, L.S. Pensamento e linguagem. Edição eletrônica de Ridendo Castigat Mores. 2001. E-book disponível em: <www.ebooksbrasil.org>. Acesso em: 20 mai. 2012.

WALLACE, M. J. Action Research for Language Teachers. Cambridge: Cambridge Universtity Press, 1998.

WANG, Wayne (Dir.) Mr. Shi (Mil anos de orações), DVD, EUA, 2007.

WELLS, G. Dialogic inquiry: Toward a sociocultural practice and theory of education. Cambridge: Cambridge University Press, 1999.

WERTSCH, J.V. Voices of mind: a sociocultural approach to mediated action. Cambridge, MA: Harvard University Press, 1991.

WOOD, Andrés (Dir.) Machuca. DVD, Chile, 2004.

WOODS, D. Teacher cognition in language teaching: beliefs, decision-making and classroom practice. Cambridge: CUP, 1996.

WOODS, D. The social construction of beliefs in the language classroom. In: KALAJA; P; BARCELOS. A. M. F. (Ed.). Beliefs about SLA: New Research Approaches. Dordrecht: Kluwer, 2003. p. 201-229.

ZOLIN-VESZ, F. (Org.) A (In)visibilidade da América Latina no Ensino de Espanhol. Campinas: Pontes, 2013.

ZOLIN-VESZ, F. Crenças sobre ensinar e aprender espanhol: reprodução e manutenção do status quo e da estratificação social. Campinas: Pontes, 2013. 